

\section{Editorial Board}

\section{Editor in Chief}

Mark Zilberman, MSc, Shiny World Corporation, Toronto, Canada

\section{Scientific Editorial Board}

Viktor Andrushhenko, PhD, Professor, Academician of the Academy of Pedagogical Sciences of Ukraine, President of the Association of Rectors of pedagogical universities in Europe

John Hodge, MSc, retired, USA

Petr Makuhin, PhD, Associate Professor, Philosophy and Social Communications faculty of Omsk State Technical University, Russia

Miroslav Pardy, PhD, Associate Professor, Department of Physical Electronics, Masaryk University, Brno, Czech Republic

Lyudmila Pet'ko, Executive Editor, PhD, Associate Professor, National Pedagogical Dragomanov University, Kiev, Ukraine

\section{IntellectualArchive, Volume 9, Number 3}

\begin{tabular}{|c|c|}
\hline $\begin{array}{l}\text { Publisher } \\
\text { Address }\end{array}$ & $\begin{array}{l}\text { Shiny World Corp. } \\
\text { 9200 Dufferin Street } \\
\text { P.O. Box } 20097 \\
\text { Concord, Ontario } \\
\text { L4K 0C0 } \\
\text { Canada }\end{array}$ \\
\hline $\begin{array}{l}\text { E-mail } \\
\text { Web Site } \\
\text { Series } \\
\text { Frequency } \\
\text { Month } \\
\text { ISSN } \\
\text { DOI } \\
\text { Trademark }\end{array}$ & $\begin{array}{l}\text { : support@IntellectualArchive.com } \\
\text { www.IntellectualArchive.com } \\
\text { Journal } \\
\text { : Every } 3 \text { months } \\
: \text { July - September } 2020 \\
1929-4700 \\
\text { 10.32370/IA_2020_09 } \\
\text { IntEllectuaIArchiveTM }\end{array}$ \\
\hline
\end{tabular}

(C) 2020 Shiny World Corp. All Rights Reserved. No reproduction allowed without permission. Copyright and moral rights of all articles belong to the individual authors. 


\section{Intellectual Archive}

Volume 9

Number 3

July/September 2020

\section{Table of Contents}

\section{Physics}

M. Zilberman

M. Pardy

J.C. Hodge

G. Negai,

O. Dorofejev

G. Negai,

N. Mashovets,

L. Strashko

A. Kofanov, N. Pavlovska, E. Svoboda,

A. Symchuk,

S. Yakovchuk

N. Pavlovska,

O. Kofanova,

M. Kulyk,

H. Strilets,

N. Filipova

G. Jegede

L. Griffen,

N. Ryzheva

A. Iskhakova
The "Dimming Effect" Produced by the Application of Doppler Effect on the

Quantity of Photons Arriving to a Receiver and its Implication to Astronomy

The thermal bath corrections to the Cooper pair potential ........................... 6

Magnetic field causes the strong and weak nuclear forces and is the GUT force ....

\section{Architecture}

Informational Assessment of Architectural Form Harmony

27

Diversity of Urban Buildings

42

\section{Law}

Some Legal Aspects of the Circulation and Research of Narcotic Drugs and

Precursors

Modern Possibilities of Forensic Land and Soil Examinations Within the Civil and Criminal Law .....

\section{History}

The Formative Stage of the Christ Apostolic Church (C.A.C) (Nigeria), 1917-1943 ..

The Driving Power of Social Processes from the Perspective of History of Science and Technology

\section{Economics}

Increased Customer Loyalty in the Retail Banking Sector and Impact on the Bank's Financial Performance 


\section{Table of Contents (continued)}

\section{Engineering}

A. Imamov

H. N. Vazirov, F. H. VazirovKangarli

O. Reipolska, V. Lutsenko

L. Popova

L. Honchar

N. Zabolotnia

I. Penza

V. Sushko

H. N. Vazirov

A. Kravz, B. Demchyna

A. Pelekh
Methods and Devices for Forming Rehabilitation Processes. Application of Artificial Intelligence and Artificial Neural Networks for Rehabilitation ....

\section{Philosophy}

Philosophical-Mathematical Paradox of Dots

103

\section{Education}

Creating a Developmentally Appropriate Learning Environment in Preschool Education Institutions

The Forming Professionally Oriented Foreign Language Communication Skills in Future Teachers of Ukrainian Primary School

Modeling the Process of Forming Culture in Professional Activities of Future Managers

Formation and Development of Interest in Music in Beginner Pupils in the Process of Learning to Play the Piano

The Development of Sociocultural Component in Professional Education of Future Navigators in the Fifties of the XXth Century

The Main Factors in the Development of Modern Ukrainian Language Education in the Southern Regions of Ukraine

Essay

From the Diary .

184

\section{Construction}

The Pliability of the Joints of Wooden Elements in the Work of Wooden Reinforced

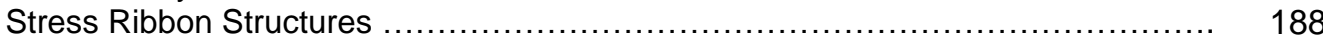

Stress-Strain State of Wooden Columns Under Uneven Local Heating 196

Manuscript Guidelines

\section{Toronto, July / September 2020}




\title{
The "Dimming Effect" Produced by the Application of Doppler Effect on the Quantity of Photons Arriving to a Receiver and its Implication to Astronomy
}

\author{
M. Zilberman, M.Sc.* \\ Independent researcher, Canada
}

\begin{abstract}
This article describes the dimming effect that is produced by the Doppler effect applied to a quantity of individual photons arriving to a receiver from a moving source of light. The corpuscular-wave dualism of light suggests that the well-known Doppler effect, which is currently applied only to the wave component of light, should also be considered for the corpuscular component of light. Application of the Doppler effect on a quantity of photons leads to the "Dimming Effect" - as the faster light source is moving away from observer - the dimmer its brightness appears. While the described dimming effect is negligible for low-speed light sources, it becomes significant for light sources with a velocity comparable to light speed in a vacuum. The relativistic adjustments for time dilation cause the described dimming effect to be even stronger. For example, the "Dimming Effect" for an object moving away from the observer with the speed $0.1 c$ is 0.904 and for an object moving away from the observer with the speed $0.5 c$ is 0.577 . If confirmed, the dimming effect must be taken into account in calculations of astronomical "Standard Candles" and in particular in the "Supernova Cosmology Project", which has claimed the acceleration of the Universe's expansion and led to the introduction of dark energy.
\end{abstract}

Keywords: Doppler effect, "Standard Candles", "Supernova Cosmology Project”, dark energy, dimming

\section{The Doppler effect for waves}

The Doppler effect is well known [1], [2] and widely used in science and engineering. This formula (1) describes the change of light frequency in a vacuum due to the Doppler effect.

$$
F=F_{0} \cdot \frac{\sqrt{1-\frac{v^{2}}{c^{2}}}}{1-\frac{v}{c} \cdot \cos \theta}
$$

Here $F_{0}$ is the radiation frequency at the source of light, $F$ is the observed radiation frequency, $C$ is the speed of light, $v$ is the speed of the source relative to the observer and $\theta$ is the angle between the direction to the source and the velocity vector in the receiver's frame of reference. If the source is radially away from the observer, then $\theta=\pi$, if it approaches, then $\theta=0$.

In astronomy the Doppler effect particularly allows the estimation of distance to far galaxies using the correspondence between their distance and redshift of the galaxies spectra.

*email address: MZilberman137@gmail.com 
On the other hand, the corpuscular-wave dualism of light is also well known. Currently the attention of physicists was focused to the application of the Doppler effect on the wave component of light. This likely occurred because the Doppler effect on sound (the entire wave object) was well researched. Upon a scan of the published literature on the topic, there do not appear to be any articles that analyzed the application of the Doppler effect on the corpuscular component of light (including relativistic effects).

\section{Thought experiment}

Imagine we watch a movie where a police car chases criminals. Since we are only concerned in the relative speed of objects, we can imagine that a police car is static and the criminal's car is distancing from it with the fixed relative speed $V$ (meters per second). For simplicity we consider an one-dimensional model and neglect any air resistance. During every second, the criminal in the car shoots one bullet at the police car. Let's denote the speed of the bullet as $S$ (meters per second) and the initial distance between cars as $D$ (meters). We also assume that $S \gg V$, not to make calculations more complex by subtracting the speed of car from the speed of bullet.

The bullet that was shot on the second number " 0 " will reach the police car after the $D / S$ seconds on the moment $D / S$ (all calculations done in the police car reference frame). During the period between the first and second shot the criminal's car moves $V(\mathrm{~m} / \mathrm{s}) \times(1$ second $)=V$ meters. Therefore, the second shot will be shot from the distance $D+V$ meters. The second bullet will hit the police car after $(D+V) / S$ seconds during the moment $(1$ second $)+(D+V) / S$. (The moment "1 second" is the moment when it was shot plus the bullet's flying time).

During the time between the second and third shots the criminal's car moves an additional $V$ meters. Therefore, the third shot will be fired from the distance of $D+V * 2$ meters. The third bullet will hit the police car after $\left(D+V^{* 2}\right) / S$ seconds during the moment $(2$ seconds $)+$ $\left(D+V^{* 2}\right) / S$. (The moment " 2 seconds" is the moment when the bullet was shot plus the bullet's flying time). And so forth.

Next, let's calculate the time interval between sequential bullets hitting the police car. The first bullet hits the police car during moment $D / S$. The second bullet hits the police car during the moment $(1$ second $)+(D+V) / S$. Therefore, the time interval between sequential bullets hitting are

$$
d T=1+(D+V) / S-D / S=1+D / S+V / S-D / S=1+V / S
$$

This result is almost obvious. If the criminal car does not drive (i.e. $V=0$ ) or if the bullets have infinite speed $(S \rightarrow \infty)$ then the bullets hit the car every second. If the speed of the criminal car is not 0 and the speed of bullets is not infinite, then the frequency of strikes is described by the formula (2). Let's also note that if the criminal's car is approaching the police car (i.e. $V<0)$ the interval between bullet strikes will be less than 1 second, which is also quite obvious.

From the formula (2) the number of bullets that strike the police car during the time interval $\mathrm{T}$ (seconds) is calculated as 


$$
N=\frac{T}{1+\frac{V}{S}}
$$

Since our model assumed a 1-dimensional movement of the car and does not consider any relativistic effects it can be understood that formula (3) and the classical formula (1) both describe the Doppler effect. The difference however is in the nature of objects they describe. Formula (1) describes the wave object (sound, light, etc.) and formula (3) describes the movement of discrete objects.

Since the number of shots during the interval $\mathrm{T}$ in seconds is also $\mathrm{T}$ (one shot per second) the number of bullets shot $\left(\mathrm{N}_{0}\right)$ and the number of bullets received $(\mathrm{N})$ per second is given by the formula (4). Depending on the direction of criminal's car, the value $\mathrm{N}$ can be less than $\mathrm{N}_{0}$ (criminal's car is moving away) or greater than $\mathrm{N}_{0}$ (criminal's car is approaching.)

$$
N=\frac{N_{0}}{1+\frac{V}{S}}
$$

\section{Application to the photon model of light}

Now let's consider the corpuscular-wave nature of light and apply the obtained formula (4) to the numbers of emitted and received photons. Let's consider an object that emits photons. If this object is not approaching the observer and is not moving away from the observer $(V=0)$, then the numbers of emitted and received photons per second are the same. However, if the object is moving to or from the observer, these numbers become different and are described by formula (4). If the source and receiver of photons are located in a vacuum, then formula (4) appears as

$$
N=\frac{N_{0}}{1+\frac{V}{C}}
$$

Here $c$ is the speed of light in a vacuum, $V$ is the speed, with which object that emits photons is moving away from observer, $\mathrm{N}_{0}$ is the number of emitted photons and $\mathrm{N}$ is the number of observed photons during a fixed time interval.

Since we define brightness of objects by the number of photons arriving to a receiver during a predefined time interval, in accordance to formula (5), the light sources approaching us $(V<0)$ will look brighter and the light sources moving away $(V>0)$ from us will look dimmer.

However, since in real life the speed of the light sources $V$ is much less than $c$, we do not observe this effect. For example, if 2 observers located at diametrically opposite points of the earth's 
equator attempt to measure the brightness of a distant object of light, located in the equatorial plane, the difference in brightness will only be

$$
460(\mathrm{~m} / \mathrm{s}) * 2 / 300,000,000(\mathrm{~m} / \mathrm{s})=3.06667 \mathrm{E}-06,
$$

where $460 \mathrm{~m} / \mathrm{s}$ is the Earth's rotating speed at the equator.

Optimistically, there is a chance that physicists can offer further sophisticated methods of affirming formula (5).

\section{Application to astronomy}

In astronomy, however, formula (5) can be tested. If we observe 2 similar objects and know their speeds and distances, we will be able to tell if their brightness depends on their speed or not. Since astronomy deals with certain objects whose speed is comparable to the speed of light in a vacuum these measurements appear attainable. For example, for an object moving away from us with the speed of $0.1 c(30,000 \mathrm{~km} / \mathrm{s})$ the effect of dimming is

$$
\mathrm{N} / \mathrm{N}_{0}=\frac{1}{1+0.1}=0.91
$$

For the object moving away from us with the speed $0.5 c(150,000 \mathrm{~km} / \mathrm{s})$ the effect of dimming is

$$
N / N_{0}=\frac{1}{1+0.5}=0.66
$$

Two comments.

a. All the above calculations do not yet take into account relativistic effects.

b. The assumption $S \gg V$ from the "thought experiment" above is not applicable to formulas (5) and (6) because the $S$ and $V$ values are now comparable. However, since we consider the emission of photons, the speed $S$ is always equal to $c$ and therefore is independent from the speed $V$ of the light source. (In the "thought experiment" above we used the $S \gg V$ assumption not to make calculations more complex by subtracting the speed of car from the speed of bullet. For emission of photons situation is different since their speed in vacuum is always equal to $c$.)

\section{Relativistic effects}

Since we consider the movement of objects with speed comparable to $c$, we must account for their relativistic effects and relativistic time dilation. According to Special Relativity the processes in the moving inertial reference frame will appear slower with the coefficient $\sqrt{1-\frac{v^{2}}{c^{2}}}$, where $v$ is the speed of the object and $c$ is the speed of light in a vacuum. For the dimming referred to above this relativistic time dilation leads to further reduced numbers of received photons per time unit compared to the number of radiated photons. Combining this time dilation effect with formula (5) we obtain formula (8) 


$$
N / N_{0}=\frac{\sqrt{1-\frac{V^{2}}{c^{2}}}}{1+\frac{V}{c}}
$$

This resemblance to the Doppler effect formula (1) is clear, because both describe fundamentally the same effect. Essentially the classical Doppler effect formula describes the wave component of light and formula (8) describes the corpuscular component of light.

Taking the relativistic effects into account we obtain the dimming effect for an object moving away from the observer with the speed $0.1 c$ as

$$
N / N_{0}=\frac{\sqrt{1-0.1 * 0.1}}{1+0.1}=0.904
$$

and for an object moving away from the observer with the speed $0.5 c$ as

$$
N / N_{0}=\frac{\sqrt{1-0.5 * 0.5}}{1+0.5} \quad=0.577
$$

In addition to Special Relativity, "Relativistic effects" covers gravitational time dilation as described by General Relativity and also by cosmological expansion. Therefore, we can expect that anywhere that the Doppler effect applies for waves (formula 1) the dimming effect will also take place (formula 8).

If confirmed by experiment the described dimming effect must be taken into account for astronomical calculations involving the "Standard Candle" and in particular the "Supernova Cosmology Project" [3], which has claimed the acceleration of the Universe's expansion and led to the introduction of dark energy.

\section{References}

1. Landau L. D., Lifshits E. M. Teoriia polia. - Izdanie 7-e, ispravlennoe. [Theory of the field. - 7th edition, revised] — M.: Nauka, 1988. — Pp. 158-159. — (Teoreticheskaia fizika, tom II ["Theoretical Physics", volume II]). — ISBN 5-02-014420-7.

2. Cotăescu Ion I., "Longitudinal Doppler effect in de Sitter relativity”, arXiv: 2007.13590, 2020

3. Goldhaber, Gerson (2009). "The Acceleration of the Expansion of the Universe: A Brief Early History of the Supernova Cosmology Project (SCP)". AIP Conference Proceedings. 1166: 53. arXiv:0907.3526. Bibcode:2009AIPC.1166...53G. doi:10.1063/1.3232196. 


\title{
The thermal bath corrections to the Cooper pair potential
}

\author{
Miroslav Pardy \\ Department of Physical Electronics \\ Masaryk University \\ Kotlářská 2, 61137 Brno, Czech Republic \\ email:pamir@physics.muni.cz
}

July 27, 2020

\begin{abstract}
The Coulomb and Yukawa potentials of particles are derived from the Schwinger field theory at zero and the finite temperature. At the same time the correction to the Coulomb potential is determined for the two charges interacting in the photon black-body sea by the photon exchange mechanism. The running coupling constant is determined in dependence on the mean free path of photons in the photon sea. The relation to the Cooper pairs and phonon-phonon interaction at the thermal bath is discussed.
\end{abstract}

\section{Introduction}

All properties of a superconductor, including ground-state energy, critical temperature, quasi-particle energy spectra containing gaps, supercondensate density, specific heat, and supercurrent density can be computed in BCS theory without mathematical complexities.

The attraction of two electrons in BCS can be in simplicity explained. An electron in a metal normally behaves as a free particle. The electron is repelled from other electrons due to their negative charge, but it also attracts the positive ions that make up the rigid lattice of the metal. This attraction distorts the ion lattice, moving the ions slightly toward the electron, increasing the positive charge density of the lattice in the vicinity. This positive charge can attract other electrons. At long distances, this attraction between electrons due to the displaced ions can overcome the electron repulsion due to their negative charge, and cause them to pair up. The quantum theory explanation shows that the effect is due to electron-phonon interactions, with the phonon being the collective motion of the positively-charged lattice. The energy of the pairing interaction is quite weak, and thermal energy can easily break the pairs. So only at low temperatures, in metal and other substrates, are a significant number of the so called Cooper pairs. 
The electrons in a pair are not necessarily close together and paired electrons may still be many hundreds of nanometers apart. This distance is usually greater than the average inter-electron distance, so, many Cooper pairs can occupy the same space. Electrons are fermions with one half spin, but the total spin of a Cooper pair is integer, zero, or one. So, it means a Cooper pair is a composite boson. This means the wave functions are symmetric under particle interchange. Therefore, unlike electrons, multiple Cooper pairs are allowed to be in the same quantum state, which is responsible for the phenomena of superconductivity.

The determination of potential at finite temperature is one of the problems which form the basic ingredients of the quantum field theory (QFT) at finite temperature. This theory was formulated some years ago by Dolan and Jackiw (1974), Weinberg (1974) and Bernard (1974) and some of the first applications of this theory were the calculations of the temperature behaviour of the effective potential in the Higgs sector of the standard model.

Information on the systematic examination of the finite temperature effects in quantum electrodynamics (QED) at one-loop order was given by Donoghue, Holstein and Robinett (1985). They have treated the calculation of mass, charge, wave function renormalization and so on and demonstrated the running of the coupling constant at finite temperature and discussed the normalized vertex function and the energy momentum tensor.

A similar discussion of QED was published by Johansson, Peressutti and Skagerstam (1986) and Cox et. al. (1984).

The finite-temperature QED, QFT and also quantum chromodynamics usually deal with the specific processes of these theories in the heat bath of photons or other particles.

The term "finite-temperature" implies the presence of the medium formed usually by the electron-positron and photon gases which is in the thermodynamical equilibrium of some temperature $T \neq 0$. Such a definition is used, for instance, by Zhukovskii et al. (1995) in the determination of the electron mass operator of the electron at finite temperature. It is evident that the heat bath can be formed by different kinds of elementary particles and so such different hot media have a different influence on the same specific physical process developing in the media.

We use here the finite-temperature methods and Schwinger theory for determination of the Coulomb and Yukawa potentials at finite temperature. At the same time we derive the modified Coulomb potential from the two-charge interaction by the exchange photon mechanism in the photon sea (Pardy, 1994a). The phonon sea as the analogue to the photon sea is discussed.

\section{Formulation of the problem in field theory}

The basic formula of the Schwinger field theory is the vacuum-vacuum amplitude (Schwinger, 1970): 


$$
\left\langle 0_{+} \mid 0_{-}\right\rangle=e^{\frac{i}{\hbar} W}
$$

where in the case of the electromagnetic field the action $W$ is defined as (Schwinger et al., 1976)

$$
W=\frac{1}{2 c^{2}} \int(d x)\left(d x^{\prime}\right) J_{\mu}(x) D_{+}^{\mu \nu}\left(x-x^{\prime}\right) J_{\nu}\left(x^{\prime}\right),
$$

where $J^{\mu} \equiv(c \varrho, \mathbf{J})$ is the conserved current and $D_{+}^{\mu \nu}\left(x-x^{\prime}\right)$ is the photon propagator in a medium with the index of refraction $n$, the magnetic permeability $\mu$ and the dielectric constant $\varepsilon$.

The equations corresponding to the action (2) are as follows:

$$
\begin{gathered}
\Delta \varphi-\frac{\mu \varepsilon}{c^{2}} \frac{\partial^{2} \varphi}{\partial t^{2}}=-\frac{1}{\varepsilon} \varrho \\
\Delta \mathbf{A}-\frac{\mu \varepsilon}{c^{2}} \frac{\partial^{2} \mathbf{A}}{\partial t^{2}}=-\frac{\mu}{c} \mathbf{J} .
\end{gathered}
$$

The explicit form of $D_{+}^{\mu \nu}\left(x-x^{\prime}\right)$ has been obtained by as (Schwinger et al., 1976)

$$
D_{+}^{\mu \nu}=\frac{\mu}{c}\left[g^{\mu \nu}+\left(1-n^{-2}\right) \beta^{\mu} \beta^{\nu}\right] D_{+}\left(x-x^{\prime}\right),
$$

where $\beta^{\mu}=(1,0)$ and

$$
D_{+}\left(x-x^{\prime}\right)=\int \frac{(d k)}{(2 \pi)^{4}} e^{i k\left(x-x^{\prime}\right)} \frac{1}{\left|\mathbf{k}^{2}\right|-n^{2}\left(k^{0}\right)^{2}-i \epsilon}
$$

with $k^{\mu}=\left(k^{0}, \mathbf{k}\right)$. The Green function $D_{+}\left(x-x^{\prime}\right)$ can be further specified as

$$
D_{+}\left(x-x^{\prime}\right)=\frac{i}{c} \frac{1}{4 \pi^{2}} \int_{0}^{\infty} d \omega \frac{\sin \frac{n \omega}{c}\left|\mathbf{x}-\mathbf{x}^{\prime}\right|}{\left|\mathbf{x}-\mathbf{x}^{\prime}\right|} e^{-i \omega\left|t-t^{\prime}\right|}
$$

by the standard contour integral method (Schwinger et al., 1976) .

The vacuum persistence probability follows from eq. (1) in the form (Schwinger et al., 1976) :

$$
\left|\left\langle 0_{+} \mid 0_{-}\right\rangle\right|^{2}=e^{-\frac{2}{\hbar} \operatorname{Im} W}
$$

In order to derive the Coulomb law at zero temperature from the action $W$, we consider the physical situation where the photon source $J_{\mu}$ varies very slowly in time. Then, in order to obtain this limit, we write for the action (2) (Schwinger, 1970):

$$
W=\frac{1}{2 c^{2}} \int(d \mathbf{x})\left(d \mathbf{x}^{\prime}\right) d x^{0} d \tau J_{\mu}\left(\mathbf{x}, x^{0}+\tau / 2\right) D_{+}^{\mu \nu}\left(\mathbf{x}-\mathbf{x}^{\prime}, \tau\right) J_{\nu}\left(\mathbf{x}^{\prime}, x^{0}-\tau / 2\right),
$$

where $D_{+}$is given by eq. (7) with $x^{0}=c t$.

Now, let us consider the quasistationary arrangement (Schwinger, 1970) in a such sense that we begin with the vacuum, we turn on these sources slowly and then keep 
them constant for a long time $\mathrm{T}$. The fact that the sources do not change appreciably in time means that their Fourier transforms are essentially restricted to zero frequency.

The structure of $W$ then reduces to an account of the instantaneous coupling of sources involving the spatial function

$$
\begin{gathered}
\int_{-\infty}^{\infty} d \tau D_{+}\left(\mathbf{x}-\mathbf{x}^{\prime}, \tau\right)= \\
\frac{i}{c} \frac{1}{4 \pi^{2}} \int_{0}^{\infty} d \omega \frac{\sin \frac{n \omega}{c}\left|\mathbf{x}-\mathbf{x}^{\prime}\right|}{\left|\mathbf{x}-\mathbf{x}^{\prime}\right|} \int_{-\infty}^{\infty} d \tau e^{-i \frac{\omega}{c}|\tau|}=\frac{1}{4 \pi} \frac{1}{\left|\mathbf{x}-\mathbf{x}^{\prime}\right|}
\end{gathered}
$$

where we have used the relation

$$
\int_{-\infty}^{\infty} d \tau e^{-i \frac{\omega}{c}|\tau|}=\frac{2 c}{i \omega}
$$

The vacuum amplitude (1) can be written in this case in the form

$$
\left\langle 0_{+} \mid 0_{-}\right\rangle=\exp \left[-i \int d x^{0} E\left(x^{0}\right)\right]
$$

where $(c=n=\mu=1)$

$$
E\left(x^{0}\right)=\frac{1}{4 \pi} \frac{1}{2} \int d \mathbf{x} d \mathbf{x}^{\prime} \frac{\left[\varrho(\mathbf{x}, t) \varrho\left(\mathbf{x}^{\prime}, t^{\prime}\right)-\mathbf{J}(\mathbf{x}, t) \cdot \mathbf{J}\left(\mathbf{x}^{\prime}, t^{\prime}\right)\right]}{\left|\mathbf{x}-\mathbf{x}^{\prime}\right|} .
$$

Now, if we restrict the situation to the stationary regime, then we get:

$$
E=\frac{1}{4 \pi} \frac{1}{2} \int d \mathbf{x} d \mathbf{x}^{\prime} \frac{\left[\varrho(\mathbf{x}) \varrho\left(\mathbf{x}^{\prime}\right)-\mathbf{J}(\mathbf{x}) \cdot \mathbf{J}\left(\mathbf{x}^{\prime}\right)\right]}{\left|\mathbf{x}-\mathbf{x}^{\prime}\right|}
$$

The last formula implies the Coulomb and Amperian interactions of charges and closed currents. We can see that a substantial step in the derivation of the Coulomb potential was the $\tau$-integration of the Green function (7).

\section{The Coulomb potential at finite temperature}

The situation at finite temperature is similar, the difference being that the Green function $D_{+}$has the finite-temperature correction as follows (Pardy, 1989):

$$
D=D_{+}+D_{T}
$$

where

$$
D_{T}\left(x-x^{\prime}\right)=\frac{i}{c} \frac{1}{2 \pi^{2}} \int_{0}^{\infty} d \omega \frac{\sin \frac{n \omega}{c}\left|\mathbf{x}-\mathbf{x}^{\prime}\right|}{\left|\mathbf{x}-\mathbf{x}^{\prime}\right|} \frac{\cos \omega\left(t-t^{\prime}\right)}{\exp (\hbar \omega / k T)-1},
$$

where $k$ is here the Boltzmann constant.

The finite-temperature correction to the original Coulomb potential is obviously an analogue of eq. (10): 


$$
V_{T}=\int_{-\infty}^{\infty} d \tau D_{T}\left(\mathbf{x}-\mathbf{x}^{\prime}, \tau\right)
$$

Using the definition of the delta-function

$$
\delta(\omega)=\frac{2}{c \pi} \int_{-\infty}^{\infty} d \tau \cos \frac{\omega}{c} \tau
$$

and after some integration we get the final formula

$$
V_{T}=\frac{i n}{8 \pi \hbar c} k T
$$

where $n$ is the index of refraction which can be determined by the plasma fluctuation methods and it depends on temperature.

The derivation of the potential at finite temperature was performed as an analogue of the derivation of the Cerenkov radiation at finite temperature where the substantial temperature effect was involved in the finite-temperature part of the photon Green function (Pardy, 1989).

The fact that the finite-temperature Green function generates the complex potential has no classical analogue, and it is a result only of the quantum field theory. We can easily see that the classical definition of potential cannot generate the complex part. If we have a charged particle immersed in the heat bath, and if $\mathbf{F}_{\text {ext }}$ is a classical external force acting on this particle, then the average average potential corresponding to this force and to the stochastical force generated by collisions of the test particle with the particles of the heat bath is as follows:

$$
-\langle V\rangle=\int_{\mathbf{a}}^{\mathbf{b}} \mathbf{F}_{e x t} \cdot d \mathbf{x}+\int_{\mathbf{a}}^{\mathbf{b}}\left\langle\mathbf{F}_{s}\right\rangle \cdot d \mathbf{x}=\int_{\mathbf{a}}^{\mathbf{b}} \mathbf{F}_{e x t} \cdot d \mathbf{x}
$$

where $\mathbf{a}$ and $\mathbf{b}$ are space points; the potential is considered between them, and $\mathbf{F}_{s}$ is the stochastic force which is caused by the collisions of a test particle with the particles of the heat bath. The average value of this stochastic force is evidently zero. In such a way, the stochastic collisions of a test particle with the particles of the medium does not generate the complex potential in classical physics. Such potential is a result only of the quantum field theory.

The physical meaning of the imaginary part of this potential can be seen from the relation $\left|\left\langle 0_{+} \mid 0_{-}\right\rangle\right|^{2} \leq 1$, which contains an exponential term dependent on temperature and which can be interpreted as the non-stability of the vacuum-to-vacuum amplitude, or, in other words, the finite life-time of the vacuum-to-vacuum transition.

\section{The Yukawa potential}

While we have worked with the massless photon field in the previous section, now let us first determine the potential for a field of massive particles. For spin 0 we have (Schwinger, 1970) 


$$
W=\frac{1}{2} \int(d x)\left(d x^{\prime}\right) K(x) \Delta_{+}\left(x-x^{\prime}\right) K(x)
$$

and for spin 1 it is (Schwinger, 1970):

$$
\begin{gathered}
W=\frac{1}{2} \int(d x)\left(d x^{\prime}\right) \times \\
{\left[J^{\mu}(x) \Delta_{+}\left(x-x^{\prime}\right) J_{\mu}\left(x^{\prime}\right)+\frac{1}{m^{2}} \partial_{\mu} J^{\mu}(x) \Delta_{+}\left(x-x^{\prime}\right) \partial_{\nu}^{\prime} J^{\nu}\left(x^{\prime}\right)\right]}
\end{gathered}
$$

with $(c=1)$,

$$
\Delta_{+}\left(x-x^{\prime}\right)=\int \frac{(d k)}{(2 \pi)^{4}} e^{i k\left(x-x^{\prime}\right)} \frac{1}{\left|\mathbf{k}^{2}\right|-\left(k^{0}\right)^{2}+m^{2}-i \epsilon},
$$

where the last formula is the Green function for the massive field with mass $m$. For higher spin the action $W$ is more complicated.

The algorithm of the calculation of the potential corresponding to the massive field with spin is the same as for the massless field. In such a way we write

$$
V(|\mathbf{x}|)=\int d \tau \Delta_{+}(\mathbf{x}, \tau)=\frac{e^{-m|\mathbf{x}|}}{4 \pi|\mathbf{x}|}
$$

In case of the finite temperature, we use the transformation

$$
\frac{1}{p^{2}+m^{2}-i \epsilon} \longrightarrow \frac{1}{p^{2}+m^{2}-i \epsilon}+\frac{2 \pi i}{\exp \beta(E-\mu)-1} \delta\left(p^{2}+m^{2}\right),
$$

where we have generalized the Einstein-Bose distribution by adding to the energy $E$ the chemical potential $\mu$. While for photons the chemical potential can be shown to be zero, for massive particles it is necessary to use the non-zero chemical potential. This potential enters the first law of thermodynamics for cases involving a varying number of particles:

$$
d E=T d S-P d V-\mu d N
$$

where $E$ is the internal energy of a system, $S$ its entropy, $P$ is pressure and $N$ is the number of particles. For the zero value of the chemical potential the formula (25) has an infra-red divergence and must be investigated by special mathematical techniques (Weldon, 1994).

The finite-temperature part of the potential can again be obtained by the $\tau$-integration of the temperature part of (25). After the $\tau$-integration and $p^{0}$-integration, we get the formula which contains the following integral

$$
I=\int_{0}^{\infty} \frac{d p^{2}}{\sqrt{p^{2}}} \sin \left(\sqrt{p^{2}}|\mathbf{x}|\right) \delta\left(p^{2}+m^{2}\right), \quad p=|\mathbf{p}|,
$$

which is evidently equal to zero because of the properties of the $\delta$-function. 
What is suprising is that the potential is equal to zero, which means that in the case of the massive particles which generate the Yukawa potential the vacuum-vacuum amplitude is not influenced by temperature.

It is necessary to say that the derived potential is not the screening potential which is discussed in QCD (Baier; Kalashnikov, 1994) and which follows from the linear response theory (Kajantie; Kapusta, 1985).

\section{The photon propagator with radiative corrections and the corresponding potential}

First, we remember how the Coulomb potential is modified if we involve radiation corrections in the photon propagator. Then, we apply, in analogy with previous chapters, the $\tau$-integration to the temperature Green function of the photon with radiative corrections. We take here the radiative corrections expressed by the vacuum polarization diagram. According to (Dittrich, 1978; Schwinger, 1973; Pardy, 1994a; 1994b; 1994c), the photon propagator with such radiative corrections is in the momentum representation of the form:

$$
\tilde{D}(k)=D(k)+\delta D(k)
$$

or,

$$
\begin{gathered}
\tilde{D}(k)=\frac{1}{|\mathbf{k}|^{2}-\left(k^{0}\right)^{2}-i \epsilon}+ \\
+\int_{4 m^{2}}^{\infty} d M^{2} \frac{a\left(M^{2}\right)}{|\mathbf{k}|^{2}-\left(k^{0}\right)^{2}+M^{2}-i \epsilon},
\end{gathered}
$$

the last term in equation (29) being derived on the virtual photon condition

$$
|\mathbf{k}|^{2}-\left(k^{0}\right)^{2}=-M^{2},
$$

where, for simplicity, we consider the index of refraction of the medium equal to 1 . The weight function $a\left(M^{2}\right)$ has been derived in the following form (Dittrich, 1978; Schwinger, 1973; Pardy, 1994a; 1994b; 1994c):

$$
a\left(M^{2}\right)=\frac{\alpha}{3 \pi} \frac{1}{M^{2}}\left(1+\frac{2 m^{2}}{M^{2}}\right)\left(1-\frac{4 m^{2}}{M^{2}}\right)^{1 / 2} .
$$

The x-representation of $D(k)$ in eq. (1) is given by the Fourier transform:

$$
\tilde{D}_{+}\left(x-x^{\prime}\right)=\int \frac{(d k)}{(2 \pi)^{4}} e^{i k\left(x-x^{\prime}\right)} \tilde{D}(k)
$$

or, 


$$
\tilde{D}_{+}\left(x-x^{\prime}\right)=D_{+}\left(x-x^{\prime}\right)+\int_{(2 m)^{2}}^{\infty} d M^{2} a\left(M^{2}\right) \Delta_{+}\left(x-x^{\prime}, M^{2}\right) .
$$

The introduction of the modified photon propagation function implies a change of interaction between static charges, i.e. the change of the Coulomb potential. By the same procedure as in the preceding text, we get $(c=1)$ :

$$
\begin{gathered}
\tilde{V}(|\mathbf{x}|)=\int_{-\infty}^{\infty} d \tau \tilde{D}_{+}(x)=\int_{-\infty}^{\infty} d \tau \int \frac{(d k)}{(2 \pi)^{4}} \tilde{D}(k) e^{i k x}= \\
\frac{1}{4 \pi|\mathbf{x}|}+\frac{\alpha}{3 \pi} \int_{(2 m)^{2}}^{\infty} \frac{d M^{2}}{M^{2}}\left(1+\frac{2 m^{2}}{M^{2}}\right)\left(1-\frac{4 m^{2}}{M^{2}}\right)^{1 / 2} \frac{e^{-M|\mathbf{x}|}}{4 \pi|\mathbf{x}|}
\end{gathered}
$$

In the case of the finite temperature regime, we use eqs. (18) and (25) in order to get $(c=\hbar=1)$ :

$$
V_{T}(|\mathbf{x}|)=\frac{i}{8 \pi} k T
$$

In other words, the temperature has no influence on forming the additional potential corresponding to radiative corrections.

The probability of the persistence of the vacuum follows from the vacuum amplitude (9) in the form (6):

$$
\left|\left\langle 0_{+} \mid 0_{-}\right\rangle\right|^{2}=e^{-\frac{2}{\hbar} \operatorname{Im} W},
$$

where in the case of the finite temperature situation $\operatorname{Im} W$ in general contains the imaginary part of the potential. Physically it means that the vacuum-vacuum transition of the physical system is influenced by the temperature environment. Since the radiative corrections term in eq. (33) involves the massive Green function, which at zero temperature gives Yukawa behaviour of the potential and at non-zero temperature is equal to zero, we can observe in experiment only contributions from the zero-temperature radiative corrections with the decay factor following from eq. (36).

\section{The two-body interaction in the photon sea with photon-photon interaction}

In the previous chapters we supposed that the potential of the particles is initiated by the massless or massive fields of these particles. In order to get the zero temperature and finite temperature potentials we used the formal derivation by means of the Green functions. Now, we consider the situation where the heat bath is the medium of photons with the temperature $T$ and the exchange photon can interact with the photons of the heat bath. The physical realization of such a medium is, for instance, the photons in the internal space of the black body with temperature $T$. The problem which we solve is one of the problems of QED in the photon sea and has its origin in the article by Tryon (1974). However, 
while Tryon in his article considers only the photon-electron interaction, we will consider here especially the photon-photon interaction where the exchanged photon interacts with thermal bath photons. We use here the notion of the mean free paths of photons in order to get the corrections to the two-body potential in the heat bath of photons. We use such an approach here because the considered processes can be visualized by Feynman diagrams and because quantum field theory does not immediately give a solution to this problem.

It has been shown many times that the heat bath of photons which forms the thermodynamical medium moving stochastically has an influence on the mass of the charged particles in that medium. On the other hand, the photon-photon interaction has an immediate influence on the behaviour of the interaction potential, and has therefore an influence on the coupling constant, in accordance with the general idea that the coupling constant depends on temperature.

Considering the thermal bath of photons inside the black body, it is evident that there are two fundamental situations of the interaction of the two charges in the photon sea.

The first situation is the process where there is the photon exchange between two charges on the condition that the exchanged photons are not influenced by the photon sea. It means that the thermal photons do not interact with the exchanged photons. According to QED this process corresponds to the Coulomb potential $V$.

The second situation is the process where the exchanged photons interact with the photon of the black-body photon sea. In other words, the interacting of the two charges is realized through the photon-photon interaction.

While the the first process is of second order in the fine structure constant $\alpha$, as easily follows from the corresponding Feynman diagrams, the second process is of sixth order and it involves the scattering of light by light where the ingoing and outgoing particles are the black-body photon and the exchanged photon.

Since the cross-section of the photon-photon interaction is vera small, it can be neglected in comparison with the electron-electron scattering.

In such a way the situation of the two-body interaction consists photon exchange between charges which can be destroyed by the photon sea. According to Partovi (1994) the collision frequency $\nu_{\gamma \gamma}$ of a given photon can be expressed by the relation:

$$
\nu_{\gamma \gamma}(k)=\frac{4448 \pi^{3} \alpha^{2}}{455625} c r_{e}^{2} k^{3}\left(T / T_{e}\right)^{6},
$$

where $k$ is a photon momentum, $r_{e}$ is the classical electron radius and $T_{e}=m=5.9 \mathrm{GK}$. Obviously the mean collision frequency can now be found by averaging $\nu_{\gamma \gamma}(k)$. The mean free path of the photon in the black-body bath is then

$$
l=\frac{c}{\text { mean collision frequency }}
$$

and according to (Partovi, 1994) it is: 


$$
l[m]=9 \times 10^{-6}\left(\frac{T[K]}{5.9 \times 10^{9}}\right)^{-9} .
$$

The probability that the photon exchange between two charges in the distance $r$ will be destroyed by the photon-photon interaction is obviously $r / l$. It is evident that if the distance between both charges is $r \geq l$, then there is no interaction between these charges because every exchanged photon interacts with some of the sea photons. So, $V_{T}$ is equal to zero with probability $r / l$ and it is equal to $V(r)$ with probability $1-r / l$ as a consequence of the existence of the mean free path of photons. Thus we can easily write the two-body potential in the photon sea in of the form

$$
V_{T}(r) \approx\left(1-\frac{r}{l}\right) V(r), \quad r \leq l,
$$

and $V_{T}=0$ for $r>l$.

The dependence of the coupling constant on temperature follows from the last formula. Namely, if we put at zero temperature

$$
V(r)=-\frac{a}{r}
$$

then it is obvious that

$$
a(r, T) \approx\left(1-\frac{r}{l}\right) a(0)
$$

and $a(r, T)=0$ for $r \geq l$, where the mean free path $l$ depends on temperature.

We see that the coupling constant following from our definition of the potential at finite temperature depends not only on temperature, but also on the distance between the particles. So we have got the specific form of the running coupling constant. It is easy to see that for sufficiently large temperature $T$ the coupling constant is approximately zero and the interaction of two particles in the photon medium is also approximately zero. So, particles are free in the sufficient high temperature regime.

While the mean free path for hydrogen under standard conditions is about $10^{-6} \mathrm{~m}$, allowing hydrogen to behave like a continuous medium on scales larger than a micron, the same quantity for a photon gas is a staggering $10^{61} \mathrm{~m}$, implying that under ordinary conditions photons behave like a collection of independent, free-streaming particles on any physically meaningful scale (Partovi, 1994). It means that the influence of the photonphoton interaction on the hydrogen spectrum is practically beyond any experimental possibilities.

The influence of the black-body radiation on the energy shift was determined experimentally by Hollberg and Hall (1984). Following the detailed calculation of Farley and Wing (1981), and using the high-precision laser spectroscopic techniques, they have measured the predicted shift of Rydberg energy levels induced by black-body radiation. The 
implementation of laser precision measurement and optical heterodyne techniques has allowed the measurement of atomic energy shifts with a precision not possible before. These measurements are consistent with the predicted finite-temperature radiative corrections to atomic energy levels induced by black-body radiation, not, of course, as a result of the photon-photon interaction, but as a result of the dynamical Stark shift and the electricdipole depopulation rate, which are effects generated by the black-body radiation and not by the change of interaction potential in the photon sea.

\section{Discussion}

We have seen how the finite-temperature potential follows from the temperature Green function in the framework of the Schwinger field theory. We have concentrated only on the Coulomb and Yukawa potentials and we derived the finite-temperature terms to these potentials using the Green fuctions of a photon with and without radiative corrections, and then by considering the processes expressed by the Feynman diagrams.

Baier and Kalashnikov (1994) determined the so-called non-Abelian screening potential in the situation beyond leading order. It is evident that the screening potential corresponds to a different physical situation than that considered by us. They determined the static QCD colour-singlet potential beyond the leading order exploiting the infra-red limit of the time-time component of the gluon self-energy $\Pi_{44}(0, \mathbf{k})$. They worked in the temporal axial gauge and used the full Schwinger-Dyson equation for $\Pi_{44}$, which includes the ring graphs and non-perturbative vertex corrections. Gauge covariance was guaranteed by the exact Slavnov-Taylor identities in order to construct the three-gluon vertex. Their result for the screening static potential $V(r)$ is as follows:

$$
V(r)=-\frac{N^{2}-1}{2 N} g^{2}(T) \int \frac{d^{3} q}{(2 \pi)^{3}} \frac{e^{i \mathbf{q} \mathbf{r}}}{q^{2}+\Pi_{44}(0, q)},
$$

where $r=|\mathbf{r}|, q=|\mathbf{q}|$ and $g(T)$ is the coupling constant at finite temperature.

The final result of their calculations is the formula:

$$
\left.V(r)\right|_{m r \longrightarrow \infty} \approx \frac{N^{2}-1}{8 \pi^{2}} \frac{3 g^{2}(T)}{(r m)^{6}} T .
$$

It is evident that the photon-photon interaction forms the analogue of the phononphonon interaction in solid states and condensed matter. Thus, in analogy with photons, we can define the mean free path of phonons and expect in the case of solid states and condensed matter the mean free path of phonons to be as follows:

$$
l=\frac{A}{T^{m}},
$$

where $A$ and $m$ are constants corresponding to the specific matter and $T$ is the temperature. It is well known that phonons are the fundamental medium which makes possible the 
heat transfer in solid states, and according to Rietschel (1994) electron-phonon interaction is the relevant mechanism in the high-temperature superconductivity.

The mean free path (46), although derived only by analogy with the photon situation in QED, is in fact realistic, because according to Anderson (1981) there exist so-called non-resonant phonon scattering mechanisms in a solid characterized by a mean free path $l \approx T^{-3}$ which is in agreement with the analogous formula (46). So, the relevance of the mean free path in solid state physics is obvious, as shown also in the article by Yang et al. (1994), where it is demonstrated that the mean free path of phonons can be determined experimentally by measuring thermal diffusivity without having the need to measure the thermal conductivity and the heat capacity per unit volume.

The mean free path plays a fundamental role in particle physics, as was shown for instance by Haglin and Pratt (1994), who studied mean free paths of pions and kaons using relativistic kinetic theory at temperature and densities characteristic of hadronic matter.

\section{References}

Anderson, A. C. (1981). Amorphous Solids: Low Temperature properties, ed. W. A. Phillips Berlin: Springer p. 65.

Baier, R. and Kalashnikov, O. K. (1994). The nonabelian screening potential beyond the leading order, Phys. Lett. B 328, 450.

Bernard, C. W. (1974). Feynman rules for gauge theories at finite temperature, Phys. Rev. D 9, 3312.

Cox, P. H., Hellman, W. S. and Yildiz, A. (1984). Finite temperature corrections to field theory: Electron mass and magnetic moment, and vacuum energy,

Ann. Phys. (N.Y.) 154, 211.

Dittrich, W. (1978). Source Methods in Quantum Field Theory, Fortschritte der Physik 26, 289.

Dolan, L., Jackiw, R. (1974). Symmetry behavior at finite temperature, Phys. Rev. D 9, 3320.

Donoghue, J. F., Holstein, B. R. and Robinett, R. W. (1985). Quantum Electrodynamics at Finite Temperature, Ann. Phys. (NY) 164 No. 2, 233.

Farley, J. W. and Wing, W. H. (1981). Accurate calculation of dynamic Stark shifts and depopulation rates of Rydberg energy levels induced by blackbody radiation. Hydrogen, helium, and alkali-metal atoms, Phys. Rev. A 23, 2397. Haglin, K. and Pratt, S. (1994). On the mean free paths of pions and kaons in hot hadronic matter, Phys. Lett. B 328, 255. nucl-th/9404007v1 6 Apr 1994 
Hollberg, L. and Hall, J. L. (1984). Measurement of the Shift of Rydberg Energy Levels Induced by Blackbody Radiation, Phys. Rev. Lett. 53, 230.

Johansson, A. E., Peressutti, G. and Skagerstam, B. S. (1986). Quantum field theory at finite temperature, Renormalization and radiative Nucl. Phys. B 278, 324.

Kajantie, K. and Kapusta, J. (1985). Behaviour of gluons at high temperature, Ann. Phys. (N.Y.) 160, 477.

Pardy, M. (1989). Finite-temperature Čerenkov radiation, Phys. Lett. A 134 No. 6, 357. Pardy, M. (1994a). The two-body potential at finite temperature, CERN-TH.7397/94

Pardy M. (1994b). The Čerenkov effect with radiative corrections,

Phys. Lett. B 325, 517.

Pardy, M. (1994c). The synchrotron production of photons with radiative corrections, Phys. Lett. A 189, 227.

Partovi, M. Hossein. (1994). QED corrections to Plancks radiation law and photon thermodynamics, Phys. Rev. D $50,1118$.

Rietschel, H. (1994). Relevance of electron-phonon coupling in high- $T_{c}$ superconductors, Journal of Low Temperature Physics, 95 Nos 1/2, 293.

Schwinger, J. Particles, Sources and Fields, Vol. I,

Addison-Wesley, Reading, Mass., (1970).

Schwinger, J., Tsai, W. Y. and Erber, T. (1976). Classical and Quantum

Theory of Synergic Synchrotron-Čerenkov Radiation, Ann. Phys. (NY) 96 No. 2, 303.

Schwinger, J. Particles, Sources and Fields Vol. II,

Addison-Wesley, Reading, Mass., (1973).

Tryon, E. P. (1974). Quantum Electrodynamics in a Photon Sea,

Phys. Rev. Lett. 32, 1139.

Yang, G., Migone, A. D. and Johnson, K. W. (1994). Relationship between thermal diffusivity and mean free path, Am. J. Phys. 62 (4), 370.

Weinberg, S. (1974). Gauge and global symmetries at high temperature, Phys. Rev. D 9, 3357.

Weldon, H. A. (1994). Cancellation of infrared divergences in thermal QED, Nucl. Phys. A 566, 581c.

Zhukovskii, V. Ch., Midodashivili, P. G. and Éminov, P. A. (1995).

Imaginary part of the electron mass operator in a static uniform magnetic field at finite temperature and nonzero chemical potential, JETP 80, No. 2, 356. 


\title{
Magnetic field causes the strong and weak nuclear forces and is the GUT force
}

\author{
John C. Hodge ${ }^{1 *}$ \\ ${ }^{1}$ Retired, 477 Mincey Rd., Franklin, NC, 28734
}

\begin{abstract}
The Scalar Theory of Everything (STOE) suggests the four fundamental forces are emergent properties of the magnetic field of permanent magnets. The STOE postulates the fractal (self-similar) principle that suggests small size scales are similar to our everyday size scale. Thus, the assembly of permanent magnets into a sphere is similar to a nucleon. The magnetic force from the sphere varies as the inverse cube of the distance from the center of the sphere (nucleon) which is approximately exponential, it has short range attractive field, it is an assembly of gluons (short photons), it explains the one proton to one electron atomic structure despite the large difference in mass, it suggests a size limit to the nucleon, it reminds of strong and weak forces, and it suggests a structure of the nucleus has protons on an outside shell. The STOE has the feature of the other sense of a "Theory of Everything" - that of a "Grand Unified Theory" (GUT).
\end{abstract}

keywords: magnet, GUT, strong force, weak force

\section{INTRODUCTION}

The Scalar Theory of Everything (STOE) posits the universe is composed of hods and plenum which emerge to form all in the universe (Hodge 2016b). The hods have the plenum highest density on one side and zero density on the other (Hodge 2018e, figure 3.1). That is, the hod is fundamentally a magnet with North and South poles. Magnetic monopoles are nonexistent. Electric effects are vortices formed in the plenum by the movement of hods through the plenum (Hodge 2018a).

The Scalar Theory of Everything (STOE) rejected the Biot-Savart Law and suggested two types of magnetic effects (Hodge 2018b,c,d). One type emanates from magnets, the other from electric currents.

The STOE suggests the self-similarity principle that posits small size scales are similar to our macro size scale. Accordingly, disk magnets were used to

*E-mail: jchodge@frontier.com 


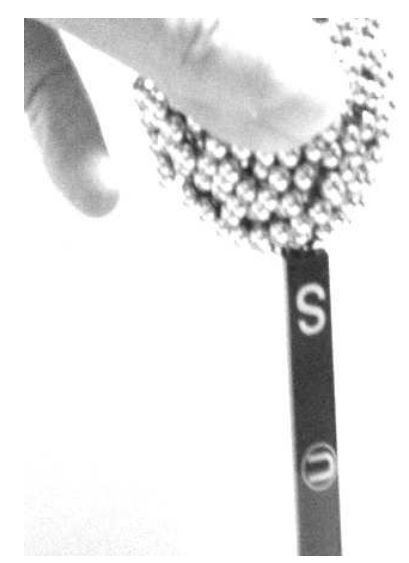

Figure 1: Sphere of ball magnets attracts the $\mathrm{S}$ pole of a bar magnet.

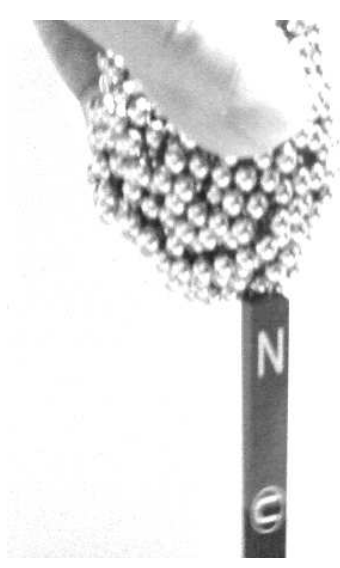

Figure 2: Sphere of ball magnets attracts the $\mathrm{N}$ pole of a bar magnet.

model photons and leptons (Hodge 2016a). This principle was used to suggest an atomic structure modeled as a structure of disk magnets (Hodge 2019b). According to the STOE, gravity is an emerged property (Hodge 2016b) of the plenum similar to the permanent magnetic effects of hods and not from an electric charge of Coulomb force (Hodge 2018a, 2019c).

Markoulakis (2020) noted that a sphere of small ball magnets could always attract other magnets as seen in Figs. 1 and 2.

This Paper describes a suggested proton structure of magnets using ball magnets to represent hods. The model of the nucleon is discussed in section 2 . The description of the experiment is in section 3. The possible structures are described in section 4. The Discussion and Conclusion are in section 5 .

\section{THE MODEL}

Figures 3 and 4 shows bar magnets aligned such that one approaches the center of the other. The lower magnet slips to the side such that there is net attraction. This is the mechanism of the sphere of ball magnets (Hodge 2019d).

However, this attraction differs from the long-distance (gravity) effect for molecules and larger (Hodge 2019c) and from the atomic structure effect (Hodge 2019b).

Examination of the balls in the sphere reveals that the $\mathrm{N}-\mathrm{S}$ axis of each ball magnet is approximately perpendicular to the radius of the sphere (Hodge $2019 \mathrm{~d})$. That is, the force of attraction along the radius of the sphere is approximately that perpendicular to a magnetic dipole. The force reduces with the inverse cube of the distance from the surface of the sphere. The ball magnets internal to the sphere are so aligned to reduce their effect external to the sphere. 


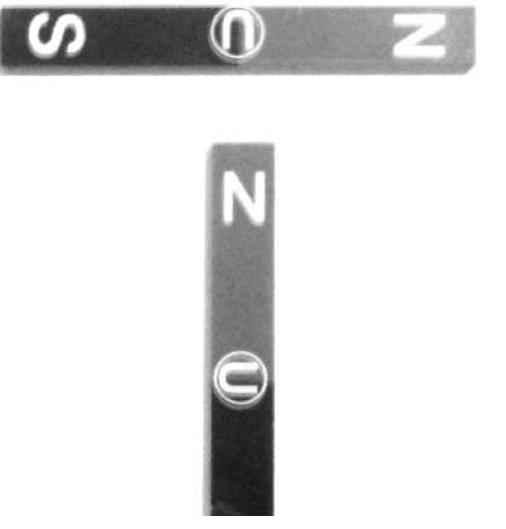

Figure 3: Bar magnets with one approaching the center of the other.

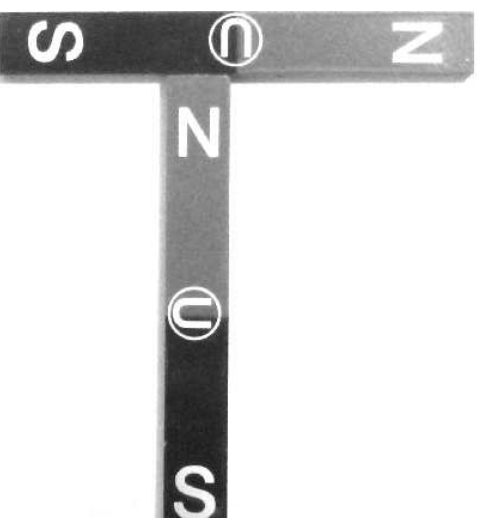

Figure 4: Bar magnets with one slipped off-center by the magnetic attraction.

Table 1: $W$ vs. $D$.

\begin{tabular}{|c|c|l|c|l|}
\hline \hline & \multicolumn{2}{|c|}{ inverse cube } & \multicolumn{2}{|c|}{ exponential } \\
\hline $\begin{array}{c}\text { No. } \\
\text { balls }\end{array}$ & $\begin{array}{c}\text { No. } \\
\text { pts. }\end{array}$ & $\begin{array}{l}W \text { Fig. } 6 \\
(\mathrm{gw})\end{array}$ & $\begin{array}{c}\text { No. } \\
\text { pts }\end{array}$ & $\begin{array}{l}W \text { Fig. } 7 \\
(\mathrm{gw})\end{array}$ \\
\hline 125 & 4 & $\left(95.6 * 1000 / D^{3}-9.8\right) \pm 0.2$ & 4 & $e^{-0.31 D+7.3} \pm 2$ \\
250 & 4 & $\left(98.1 * 1000 / D^{3}-2.2\right) \pm 0.05$ & 4 & $e^{-0.6 D+16} \pm 0.7$ \\
500 & 4 & $\left(734 * 1000 / D^{3}-16.5\right) \pm 2$ & 4 & $e^{-0.29 D+11} \pm 1.5$ \\
900 & 4 & $\left(748 * 1000 / D^{3}-16.4\right) \pm 0.1$ & 3 & $e^{-0.5 D+18} \pm 0.06$ \\
\hline
\end{tabular}

These magnets can form smaller particles such as seen in photons, neutrinos, and electrons (Hodge 2016a).

\section{THE EXPERIMENT}

The diagram in Figure 5 shows the experimental setup. Ball magnets $(5 \mathrm{~mm}$ diameter) are used to make spheres of ball magnets. The same experiment setup and procedure that was used in Hodge (2019a) is used in this experiment. The top wood support is lowered to change the distance between magnets $d$. The distance between the center of the sphere and the magnet $D=d+B / 2 \mathrm{~mm}$ (see Fig. 5).

The scale is "zeroed" by weighing the lower assembly without the top magnet in position. The weight measured $W$ gram weight (gw) is with the top magnet in position. Therefore, the $W$ is the force exerted by the top magnet on the bottom magnet.

(All measurement are $\pm 10 \%$ unless otherwise stated). 


\section{THE EXPERIMENT}

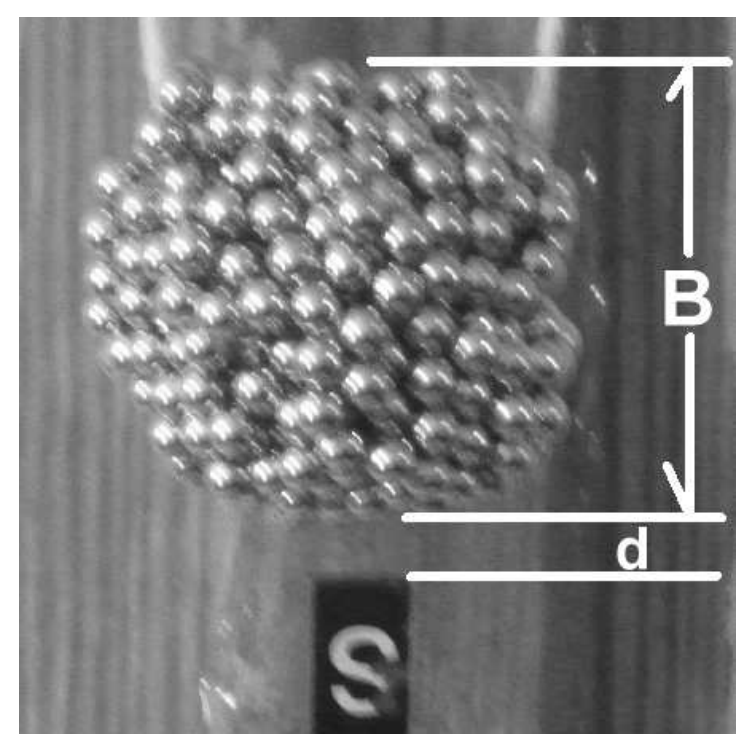

Figure 5: Photo of the experimental fixtures showing the sphere and bar magnet.

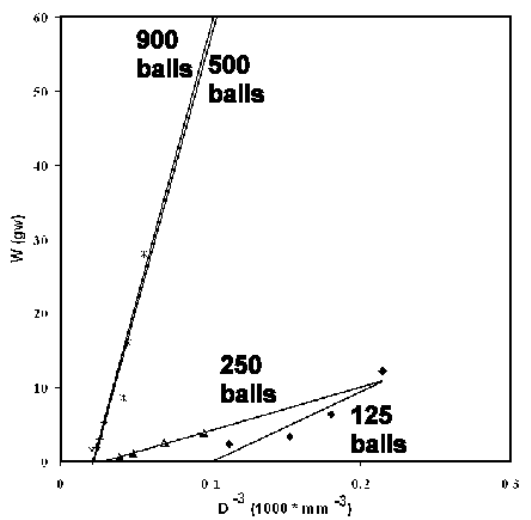

Figure 6: Graph of $W$ vs. $D^{-3}$ for various Sphere sizes showing the linear regression best fits.

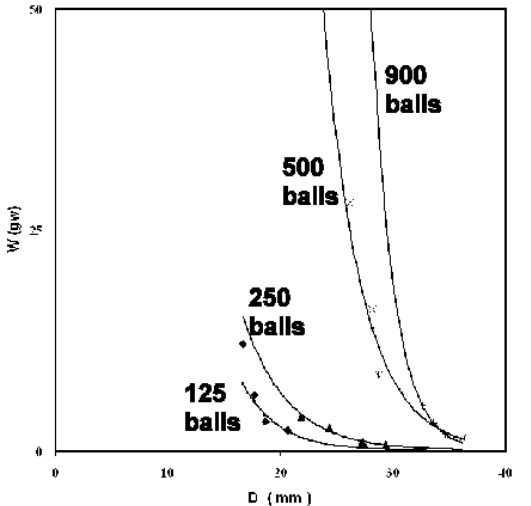

Figure 7: Graph of $W$ vs. $D$ for various Sphere sizes showing the exponential best fits. 


\section{POSSIBLE STRUCTURES}

The inverse cube of the force from the sphere is a slightly better fit to the data than the exponential. This was found in the initial paper on the magnetic field evolving to gravity (Hodge 2019a) and is a characteristic of magnets with the N-S pole axis perpendicular to the measurement. Gravity, which is a mismatch to the magnetic pole strength at distances larger than the atomic scale (Hodge 2019c), is considerably smaller than the magnetic strength that is still present in the nucleus.

Figure 8 shows a possible structure with the proton magnetically attached to a neutron (the slightly smaller sphere on the left). This causes a slightly high magnetic attaching force on the opposite side where a photon [a column of hods / magnets (Hodge 2016a)] is attached. Hodge (2012) and several experiments show this model of a photon are not rejected by several experiment that reject wave models of interference.

Figure 9 shows the result if another photon is attracted to the proton. The photons magnetically join to become one entity to connect to the electron on the other end of the photon (Hodge 2016a).

Figure 10 shows the result if the photon is too short or of insufficient energy. The other end is also attracted to the sphere/proton and the connection to the electron fails.

Figure 11 shows that other subatomic particles (the small sphere) or neutron become attached.

Figure 12 shows what happens if the sphere is pulled apart. Note the short, photon-looking structures with each end terminating on the sphere. These are suggested to be the analogy to gluons inside the protons and neutrons.

By suggesting a magnetic dominated structure, the model is including the tendency toward minimum potential energy as the guiding consideration in forming structures. If another proton neutron pair becomes attached, the proton must have a side facing outward to attach an electron through the photon. The only stable structure is for the neutron to attach to the neutron and the proton to the proton.

A longstanding problem in both nuclear structure and atomic structure is the electric concept of the one proton to one electron compared to the large mass difference. The charge model of the atom suggests the proton should have an equal but opposite charge of the electron. The large mass difference would seem to suggest a charge difference. The magnetic strength holds the nucleus and the atomic structure together (Hodge 2019b) with photons holding one electron to one proton. Further, the experiment shows the inverse cube force is very short range, less than the a tenth of the diameter of the sphere. For a proton this is about $0.1 \mathrm{fm}$. in agreement with findings for the strong force. 


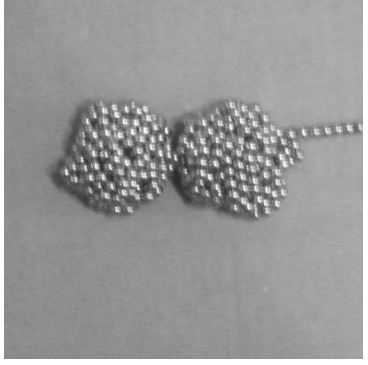

Figure 8: Possible structure of a proton, neutron, and photon attachment.
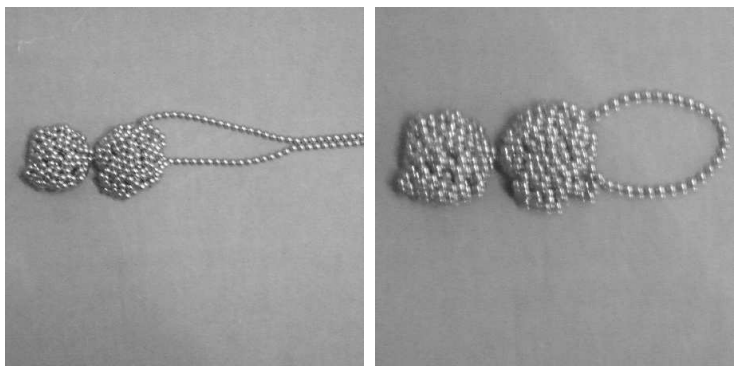

Figure 9: What hap- Figure 10: What happens when another pho- pens when the photon is ton tries to attach to too short, less than sufthe proton.

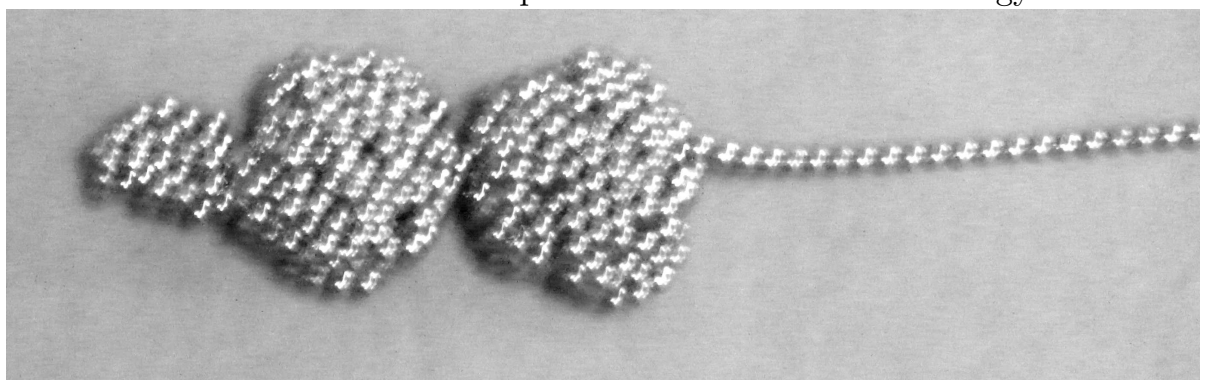

Figure 11: Other subatomic particles or neutrons can become attached to the neutron side.

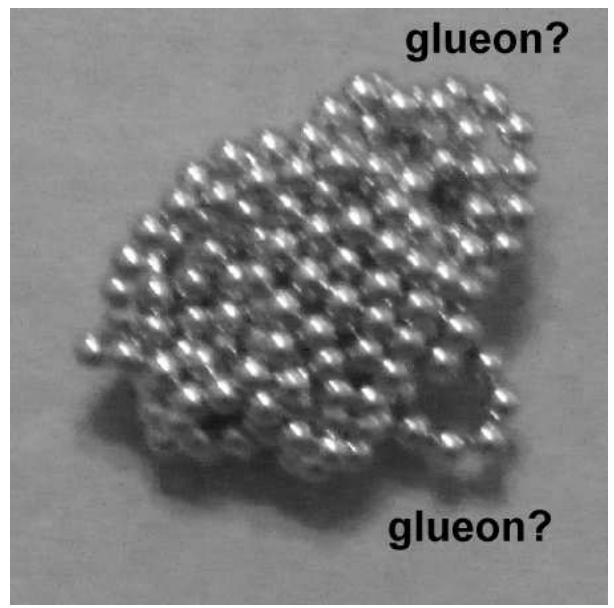

Figure 12: What happens when a sphere is pulled apart showing possible glueons. 


\section{DISCUSSION AND CONCLUSION}

The attractive effect of the proton is not the same as the long-distance (gravity) effect for molecules and larger (Hodge 2019c) and not the same as the atomic structure effect of Hodge (2019b). The magnetic ball sphere has the attractive force similar to the force expected by the Gauge Theory. That is, it is shorter range than the diameter of the sphere and is close to the exponential falloff with distance. Further, the interior structure of the sphere is of series of N-S magnetic coupling and appears as short photons. These bear the resemblance of gluons in the Gauge Theory.

More neutron-proton pairs combine to form a shell with protons on the outside and neutrons on the inside - a hollow sphere where other neutrons may collect. So, protons on the outside allow the electron to attach through photons one electron to one proton for stability, as observed. Note this is a considerable change to the model of a nucleus as being a jumble of nuclei.

This structure may offer a means to predict experiments. An extra neutron for large nuclei could cause an imbalance or a need to grow in size not allowed by the proton shell dimensions. So, fission results. Radioactive decay may also be a means to study the suggested structure. At least this model may suggest a method to evaluate radioactive decay whereas current model consider the topic an unresolvable problem. Such mechanisms are unknown but the results are well chronicled.

On the other hand, this speculation is consistent with the STOE model that gravity, the strong force, and the weak force are emergent effects of the plenum.

The suggested toy model of a nucleus has the potential to relate several and unexplained problem observations.

The STOE suggests the magnetic force is the Grand Unified Theory (GUT) that unites the four fundamental forces. The STOE began as a single model of both the big of cosmology and the small. The STOE postulates the fractal (self-similar) principle that suggests small size scales are similar to our everyday size scale. Thus, the assembly of permanent magnets into a sphere is similar to a nucleon. The present magnetic model of the nucleus exhibits many properties of the nucleus and atomic structure. Thus, it may serve as a model to discover other characteristics of nuclear structure. The magnetic force from the sphere varies as the inverse cube of the distance from the center of the sphere (nucleon), it has short range attractive field, it is an assembly of gluons (short photons), it explains the one proton to one electron atomic structure despite the large difference in mass, it suggests a size limit to the nucleon, it reminds of strong and weak forces, and it suggests a structure of the nucleus has protons on an outside shell. The STOE has the feature of the other sense of a "Theory of Everything" - that of a "Grand Unified Theory" (GUT). 


\section{REFERENCES}

\section{References}

Hodge, J.C., 2012, Photon diffraction and interference, IntellectualArchive, Vol.1, No. 3, P. 20, http://intellectualarchive.com/?link=item\&id=597

Hodge, J.C., 2016a, Structure and spin of the neutrino, electron, and positron, IntellectualArchive, Vol.5, No. 5, P. 1,. http://intellectualarchive.com/?link=item\&id=1694

Hodge, J.C., 2016b, STOE emergence, http://intellectualarchive.com/?link=item\&id=1757

Hodge, J.C., 2018a, STOE electric charge, IntellectualArchive, Vol.7, No. 2, P 1. 1 , http://intellectualarchive.com/?link=item\&id=1917

Hodge, J.C., 2018b, Magnetostatics relation to gravity with experiment that rejects Biot-Savart Law, IntellectualArchive, Vol.7, No. 3, P. 1,. http://intellectualarchive.com/?link=item\&id=1945

Hodge, J.C., 2018c, Another experiment rejects Ampere's Law and supports the STOE model, IntellectualArchive, Vol.7, No. 4, P. 6,. http://intellectualarchive.com/?link=item\&id=1956

Hodge, J.C., 2018d, Two different types of magnetic field, IntellectualArchive, Vol.4, No. 4, P. 1,. http://intellectualarchive.com/?link=item\&id=1964

Hodge, J.C., 2018e, STOE replaces relativity and quantum mechanics, (ISBN 978-613-9-91465-4, (LAP LAMBERT Acedemic publishing, Mauritius, available through Amazon.com).

Hodge, J.C., 2019a, Magnetic field evolves to gravity field Part 1: Repulsion , http://intellectualarchive.com/?link=item\&id=2164

Hodge, J.C., 2019b, Magnetic field evolves to gravity field part:4 Atomic structure, IntellectualArchive, Vol.8, No. 4, P. 30,. http://intellectualarchive.com/?link=item\&id=2199

Hodge, J.C., 2019c, Magnetic field evolves to gravity field part:5 Final, IntellectualArchive, Vol.8, No. 4, P. 37,. http://intellectualarchive.com/?link=item\&id=2233

Hodge, J.C., 2019d, video: https://www.youtube.com/watch?v=B1uGyD8uNwM

Markoulakis, E. 2020, personal communications in response to Hodge (2019b). https://www.youtube.com/watch?v=HZrv7V41qm0 https://www.youtube.com/watch?v=utlnD0yhmA8 
UDC 72.013

\title{
Informational Assessment of Architectural Form Harmony
}

\author{
Negai G.A. \\ Candidate of Architecture, Associate Professor \\ Khmelnytskyi National University, Ukraine \\ Dorofejev O.A. \\ Candidate of Technical Sciences, Associate Professor \\ Khmelnytskyi National University, Ukraine
}

\begin{abstract}
This article considers the problem of objective assessment of the architectural form harmony. The illegality of assessment methods based on the laws of geometric construction of facade compositions on the example of the western Parthenon facade and the use of the "golden section" in the study of proportional structure are grounded. Based on the theory of Eisenko's aesthetic measure and the distinctive theoretical and informational model developed by us, a method of information assessment of the architectural form harmony is proposed. This method is based on the calculation of the amount of visual information contained in the ratios of the elements of the dimensional structure, the identification of information modularity and the establishment of the strength of information connections of the elements relations of the dimensional structure. The assessment of the perceived harmony of the architectural form is carried out in accordance with the principle of the least action and is demonstrated by a specific example.
\end{abstract}

Keywords: architectural form, harmony, proportionality, visual information, information field, field of tolerance.

In today's architectural practice, the assessment of the harmony of design decisions is carried out subjectively, on an intuitive level, both at the design stage and at the stage of approval and adoption of design documentation. However, creative intuition is not always a reliable method of assessing the quality of designed architectural objects, especially the harmony of their architectural form. Therefore, there is a need for an objective assessment of this important characteristic of the architectural environment.

Harmony has always been associated with the "golden section" that began to be "adored" during Leonardo da Vinci's time thanks to his like-minded monk Luca Pacolli. He called the golden ratio "divine proportion." Thus, during the High Renaissance, harmony in architecture began to be identified with the "golden section". And this delusion has been going on for almost 500 years. We will talk about this below. For now, let us remind you that the architecture of Ancient Greece of Pericles' time was considered the most harmonious, 
especially the Parthenon of the Acropolis of Athens, the most authoritative masterpiece of the world architecture. Every researcher who has seen the Parthenon can confirm that it is really excitingly harmonious, it is beautiful. But what makes it so, what is the secret of its harmony?

"Harmonies" in Greek are nails that fasten the wooden elements of ships, making them monolithic, uniting these elements into a single whole. The question arises: what fastened the Parthenon into a coherent architectural composition? What served as "harmonies" for him? And there have always been two answers to this question: the proportions and patterns of geometric construction.

As it has been noted above, harmony has always been identified with the "golden section" - 1: 1,618. But such a ratio of elements of the dimensional structure was not found by the researchers of the Parthenon phenomenon, except for Russian theorists I.V. Zholtovskyi and I.Sh. Shevelyova. The first one resorted to falsification, to "corrections" of the dimensional structure in order to adjust it to the ratio of the "golden section". We will talk about that later. Proponents of the "geometric" concept of the nature of the Parthenon harmony proposed various schemes of construction, which were to convince readers that the secret of the beauty of the Parthenon is solved. One such scheme is given below (Fig. 1). This is a structural analysis of the facade of the Parthenon by D. Hambidge [1].

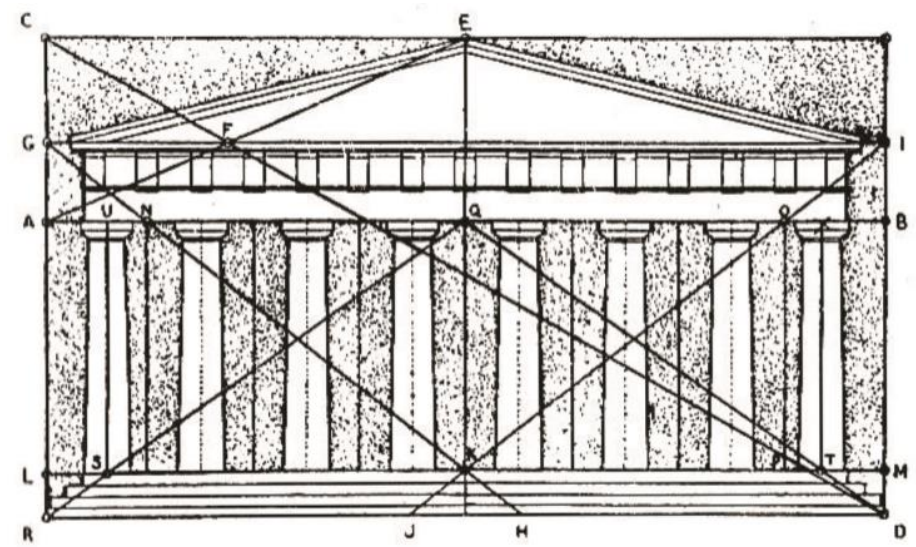

Fig. 1. Scheme of the Parthenon façade's construction (according to D. Hambidge)

D. Hambidge arbitrarily fits so-called "dynamic rectangles" into the Parthenon facade, including the stylobate, despite the fact that it is only a platform on which the temple was built, and therefore its inclusion in the proportional construction is illegal. In addition, the sides of the large rectangle, drawn at the extreme points of the eutentery, are at a distance of 
about one meter from the entablature on each side. Therefore, to put it mildly, such a "correction" of the dimensional structure of the Parthenon facade is not correct. We see the same incorrect geometric construction in Messel's scheme (Fig. 2) on the basis of "circle geometry" as a "standard of proportions" [2].

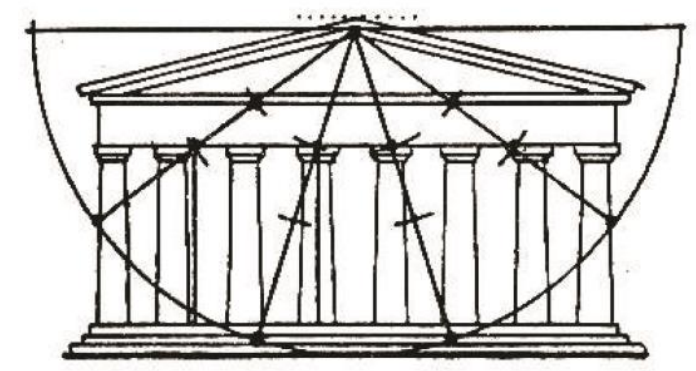

Fig. 2. Structural analysis of the Parthenon facade (according to Messel)

In the ratios needed by I. Zholtovsky to confirm the proportional system of the Parthenon on the basis of "golden section" and "function", he took the height of the pediment without cornice, although the cornice illuminates the pediment field, and the height of the entablature is taken from the top of the cornice to the bottom of capitals. And, again, the ratio of vertical dimensions gable + entablature and colonnade + stylobate, tied to the golden section, is not logical and arbitrary, because stylobate is only a platform for a temple, which is designed to level the rocky surface, and has nothing to do to with the colonnade in the structure. That is, I. Zholtovskyi chose the elements of the dimensional structure arbitrarily so that they fit into the ratio of the golden section. Such a "fit" can not reveal the nature of the Parthenon harmony (Fig. 3).

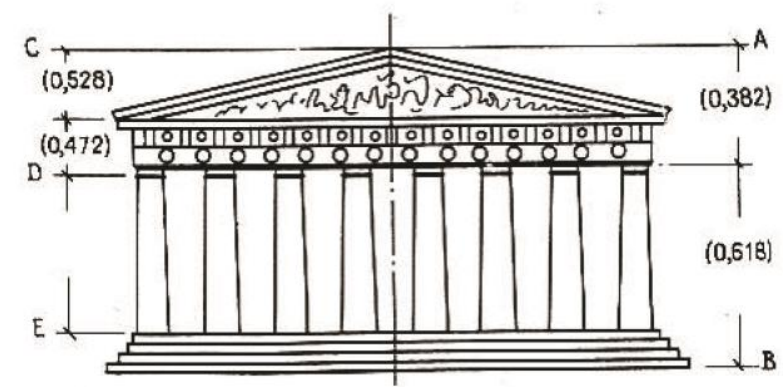

Fig. 3. Analysis of the function of the golden section on the example of the western Parthenon facade 
The most thorough studies of the proportional system of the Parthenon, which could shed light on the nature of the harmony of the Parthenon, were conducted by I. Shevelyov [3]. But the main feature, and at the same time the disadvantage of his study, is that, analyzing the "logic of architectural harmony" of the Parthenon, he took not those elements of dimensional structure that form a visually perceived harmony, but constructive dimensions along the axes of columns. After all, only in the process of visual perception, rather than constructive thinking, we feel the harmony of the architectural form.

The perception and sense of the architectural form harmony occurs through the perception of visual information, the carrier of which is the architectural form. Due to the perception of this information, we perceive and feel the beauty (harmony) of the architectural form.

Since the time of Vitruvius, the concept of harmony has been associated with the concept of proportionality. Harmony was synonymous with beauty. In the Enlightenment, harmony was understood as "unity in diversity." In the early twentieth century this interpretation of harmony was replaced by a clearer formula - "order in complexity."

The author of this concept, Birkhoff, believed that the aesthetic measure is inversely proportional to complexity. Further research and historical practice have shown the complete groundlessness of this understanding of beauty and harmony. Evidence of this is the fact that most of the architectural monuments, built in such complicated styles as Gothic or Baroque, were extremely beautiful. Therefore, Birkhoff's concept was replaced by the opposite concept of Hans Eysenck - beauty is directly proportional to both complexity and order [4].

H. Eysenkck's theory of aesthetic measure was used by us to build a system of informational assessment of the harmony of architectural composition. In 1957 Eysenck proposed a formula for aesthetic measure:

$$
M=O \times C,
$$

where $O$ - orderliness of the object assessed;

$C$ - complexity of the aesthetic assessment of the object.

Eysenkck's aesthetic concept is based on the psychophysiological hypothesis that the feeling of pleasure (aesthetic comfort) is inversely proportional to the mental energy expended on the perception of the object. 
Now, in order to determine the degree of beauty (or harmony, because beauty is the harmony we perceive and feel), it is necessary to determine the physical nature and the degree of complexity and orderliness.

It is not known what criteria Hans Eysenck used to determine complexity and orderliness. His formula of aesthetic measure was empirical, conceptual. However, despite the physical uncertainty of complexity and orderliness, the formula of beauty and harmony is recognized as such which does not contradict the historical practice.

Thus, at the initial stage of formalization of the harmony of the architectural form, one can use the empirical formula of Eysenkck's aesthetic measure.

Complexity, as one of the components of the formula, is quite understandable. It has an informational nature: the more visual information the object of perception contains, the more complex it is and the higher its aesthetic expressiveness, the more harmonious it is. In this case, the object of perception should be as orderly as possible. Orderliness is a quality opposite (inverse) to disorderliness, i.e.

$$
O=\frac{1}{D}
$$

where $D$ - quantified disorderliness.

Now Eysenkck's aesthetic measure will look like this:

$$
M=\frac{C}{D}
$$

The disorderliness of any composition will be determined by the number of relationships between its elements. The more types of relationships, the higher is the disorderliness. The most ordered composition, in accordance with this postulate, will be number one, that is, in case of only one type of relationship.

Thus, the aesthetic measure, visually perceived harmony, depends on the proportional orderliness, because the proportionality is the orderliness of the system of dimensional characteristics of the architectural form in one relationship.

As can be seen from equation (3), harmony is directly proportional to the complexity (C) (informativeness) of the architectural form, or system of relationships, and inversely proportional to the disorderliness $(D)$ of the architectural form. The informativeness of the architectural form can be determined by using our distinctive informational model: 


$$
U=k \cdot \lg \frac{r_{i}}{r_{j}}[5]
$$

where $k$ is the coefficient that takes into account the sensitivity of the visual system to the perception of differences in the elements of the dimensional structure $r_{i}$ and $r_{j}$; with sensitivity $c=\frac{1}{33} \quad k=76,56$.

The amount of visually perceived information contained in relation to two adjacent dimensional characteristics of the architectural form is called the informational step.

Using the above formula (4), we investigate the informational properties of proportionality. All members of any proportional series of quantities are interdependent by dependence:

$$
\frac{r_{i}}{r_{j}}=p^{S}
$$

where $p$ is the basis of a proportional series of quantities, that is, the ratio of two adjacent members of the series;

$s-$ an indicator of the degree that characterizes the relative position of the members of the proportional series, the difference of their serial numbers.

The amount of information contained in one member of the proportional series in relation to any other member of the same series is equal to:

$$
\mathrm{U}=k \cdot \lg \frac{r_{i}}{r_{j}}=k \cdot \lg p^{S}=s k \lg p
$$

where $s=1,2,3 \ldots-$ is an integer of a natural series that depends on the relative position of the elements in this series;

$p$ and $k$-const for any proportional series of values and is its information module $\mu$.

The unit of visual information is the eler-elementary distinction that corresponds to the discriminative sensitivity of the visual system [6]. Elements of the dimensional structure of the architectural form are all the dimensions of architectural divisions that form its compositional system and are the carriers of visually perceptible information, such as width and height of the window opening, column height in the ancient temple, column diameter, entablature height and its elements and so on. 
If in the process of studying the architectural composition, for example, the facade of an ancient temple, the obtained informational steps using the above informational model are multiples of a certain information module, for example, 10 eler ( $\mu=10$ eler $)$, it indicates that the elements of the dimensional structure forming these relations (steps ), one proportional series of values with the base $p=1,35$.

The value of the informational module in relation to the information steps that it connects, characterizes their informational (proportional) unity, and hence the degree of harmony of the architectural form.

Now we can perform an informational analysis of the proportionality of the western facade of the Parthenon, which is recognized as the most harmonious temple of ancient Greece.

To obtain reliable results of the study of the harmony of its facade, at first we will conduct a structural-level differentiation of its elements:

- the level of the whole - the width of the facade (on the architrave), the height of the facade from the upper step of the stylobate to the top of the entablature;

- the level of parts of the whole: the height of the colonnade (from the top step of the stylobate to the bottom of the architrave); the height of the entablature from the upper edge of the abacus to the lower edge of the cornice; the height of the entablature with the pediment; lower intercolumn; the lower diameter of the middle column; the height of the entablature to the modulus;

- level of elements: width of abacus; the distance between the abacus; the upper diameter of the column; upper intercolumn;

- - level of details: width of a triglyph without extreme (not illuminated by the sun) flutes; width of a triglyph with an extreme flute; metope width between triglyphs; width of the metope with the extreme groove of the triglyph.

It is necessary to note that the dimensions of triglyphs and metopes adopted by us pursue the goal of including in the analysis not constructive, but visually perceived elements of the dimensional structure. The same applies to the height of the entablature to the bottom of the cornice, because it casts a deep shadow on the frieze and divides the entablature into two parts, which are visually perceived separately from each other. This is done to clearly delineate the fields of tolerance, because just the lower edge of the cornice divides the upper 
part of the temple into two different fields: a pediment with a sculptural tympanum and a triglyph-metope frieze with an architrave. The lower part, the colonnade, includes two types of tolerance fields: shaded intercolumn cavities and sunlit columns. Stylobate was not included in the calculation because it is actually a leveling platform, which is an extension of the rocky base and has a horizontal structure as opposed to the verticals of columns and intercolumns. In addition, the temple is erected in such a way that the upper plane of the stereobate is at eye level of the person perceiving the view.

The calculation of the amount of visual information contained in the relations of the elements of the dimensional structure of each structural level, informational steps, has been carried out using a distinguishing informational model [4]. Thus, in the numerator of the relation the bigger size has been put to receive positive value of the information. All vertical elements have been increased by $5 \%$, taking into account the revaluation by the visual system of their natural size. Informational steps have been applied to the linear drawing of the facade, forming an informational field. All dimensions have been taken from the monograph by I. Shevelyov [2], who used very accurate measurements of a Greek architect Nicholas Balanos.

Let us follow the informational field of the Parthenon facade from the level of the whole to the level of details on the informational links of correlations:

Integer level:

$$
\begin{aligned}
& \frac{\text { facade width (by architrave) }}{\text { order height }(\text { without stylobate) }} \equiv 25 \text { eler } \\
& \frac{\text { column height }}{\text { lower middle intercolumn }} \equiv 50 \text { eler }
\end{aligned}
$$

As we can see, these correlations have a strong informational connection based on a common informational module $\mu=25$ eler .

The ratio of the level of parts of the whole:

$\frac{\text { height of the upperpart of the temple (from the bottom of the architrave) }}{\text { column height }} \equiv 10$ eler .

The proportionality of the last ratio of the intercolumn is determined by the informational module $\mu=10$ eler - a strong informational connection.

The ratio of the structural level of the elements: 


$$
\begin{aligned}
& \left.\begin{array}{l}
\frac{\text { column height }}{\text { the lower diameter of the column }} \equiv 60 \text { eler; } \\
\frac{\text { upperintercolumn }}{\text { the upperdiameter of the column }} \equiv 20 \text { eler. }
\end{array}\right\} \mu=20 \text { eler ; } \\
& \frac{\text { abacus width }}{\text { the upperdiameter of the column }} \equiv 10 \text { eler ; } \\
& \frac{\text { extreme upperintercolumn }}{\text { the interval between the abacus of the extreme columns }} \equiv 10 \text { eler ; } \\
& \frac{\text { architraves }+ \text { frieze (to modules) }}{\text { abacus width }} \equiv 10 \text { eler ; } \\
& \frac{\text { architraves }+ \text { frieze (with modules) }}{\text { the interval between the abacuses }} \equiv 10 \text { eler } \text {. }
\end{aligned}
$$

At the level of elements and parts, there are also ratios corresponding to the informational step of 12 eler. They have a strong informational connection with the relationship between the whole and parts of the whole (intercolumn).

Let's compare: $(12+0,5) \times 2=25$ елер and $(12+0,5) \times 4=50$ елер .

The addition of 0.5 eler is legitimate because this value is a subthreshold and is not registered by the human visual system. Informational steps of 20 and 7 eler are informationally connected, having a common informational module of 7 eler: $7 \times 3=21(20+1)$ eler. One eler is the limit for distinguishing and the value of the informational step of 20 eler is not perceived.

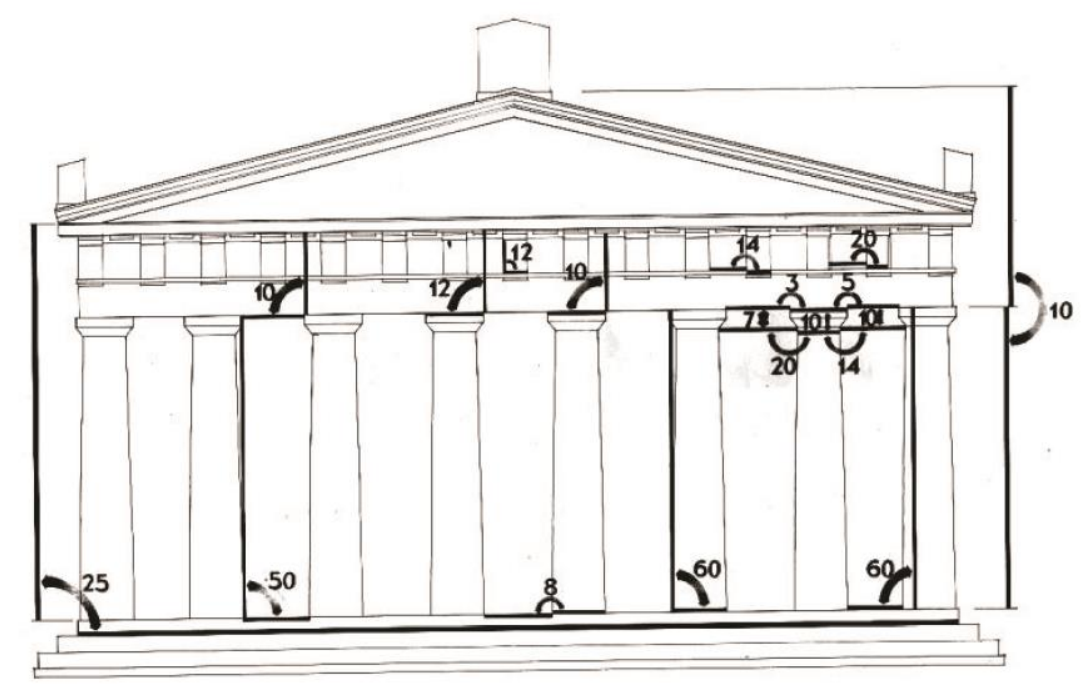

Fig. 4. Information field of the Parthenon facade 
The calculations of informational steps at the levels of the whole and the elements have shown that most of the ratios are related by a common informational module of 10 elers, which indicates that the elements of the dimensional structure belong to one proportional series of values (Fig. 4).

If we substitute in formula (4) $r_{i} / r_{j}=1,618-$ the ratio of the golden section, we obtain 16 elers. As you can see, there is no such informational step in the informational field of the Parthenon facade. This means that the harmony of the western façade of the Parthenon has nothing to do with the golden ratio.

What can explain such an obvious informational unity of the relations of the elements of the dimensional structure of the Parthenon? How did the chief architect of the Parthenon, Iktin, achieve high proportions? It is not known whether he used only fantastic intuition and a sense of harmony, or whether he used a certain mathematical apparatus. One can only assume that in the Pythagorean era, when the Parthenon was created, its harmony was the result of the Pythagorean quantitative concept of harmony. It is most likely that Iktin used the method of elevation and extraction of square and cubic roots. Alberti drew attention to this: "... for the limitations of the parties there are some relations that cannot be determined by numbers, but are drawn from the roots and degrees" [7 books. 9, ch. 6, p. 323] (highlighted by us).

If we elevate to the $2 \mathrm{nd}, 3 \mathrm{rd}$, 4th and 5th degree 1.35 (\$10 eler) and substitute into formula (4), we get: 20, 30, 40, 50 eler. Exactly these informational steps we see on the informational field of the Parthenon facade.

After the informational research, a natural question arises - is it possible to determine the absolute assessment of the harmony of two alternative objects to choose the best?

We think it is possible. But not by considering that these objects are built on the basis of a golden section, or some other "authoritative" proportion. As shown above on the example of the Parthenon, harmony is not always associated with the golden ratio. And if so, then what does the feeling of harmony of objects of perception depend on?

It should be reminded that the feeling of harmony of the architectural form is a purely informational phenomenon associated with the perception of visual information. The harmony of the architectural form can be quantified if we consider it as a sensory 
phenomenon in terms of the general scientific essence of perception. It takes into consideration the fact that any living system to ensure its viability seeks for consuming the maximum amount of information from the external environment at the minimum cost of already accumulated information to absorb the incoming. This is quite logical, because development is the accumulation of information, and if the system spends more than it receives, it will not develop, it will degrade. Thus, this progressive meaning of informational processes in living nature reflects the principle of the least action.

If we consider the information coming to our visual system as a result of the interaction of this information with human informational memory, then the rationality of this interaction will be judged by how many firmware of our memory is used in the process of perception and how much information fell on one firmware.

As early as 1912, D. Bancroft gave the following interpretation of the principle of the least action for biological systems: "Changes that affect the system (biological), such that they seek to minimize the perturbation of the external order" [7, p. 12]. In other words, informational processes take place in the biological system in such a way as to organize the information of the external world as much as possible in order to perform a minimum number of actions on its perception. This is the principle of the least effect of visual perception.

Since the information, according to our interpretation of A. Kolmogorov, is the "length of the perception algorithm", and informational modules are separate operations that connect adjacent informational steps, the effectiveness of perception will be determined by the amount of information per operation. This value will reflect the magnitude of the visual system and the informational order of the architectural form, that is, its proportionality (harmony).

The size of the informational module in relation to the informational steps that it connects, characterizes their informational unity. If we take the maximum unity indicator for 1 , then it can be achieved only if the informational steps are the same, i.e., their information module will be equal to the informational steps, i.e., $U_{i}=U_{j}=\mu$. In this case, the indicator of informational unity (strength of harmony) is determined by the formula:

$$
P_{h}=\frac{2 \mu}{U_{i}+U_{j}} .
$$


The same formula will determine the indicator of the strength of proportionality (harmony) of any pairwise adjacent informational steps of the architectural form. The number of informational modules contained in two adjacent informational steps is their modular capacity:

$$
E_{c a p}=\frac{U_{i}+U_{j}}{\mu_{i j}} .
$$

The modular capacity of the composition containing $m$ pairs of informational steps will be equal to:

$$
E_{c o m}=\sum_{2}^{m} \frac{U_{i}+U_{j}}{\mu_{i j}} .
$$

The index of harmony (measure of harmony) of the composition, containing $m$ pairs of information steps, will be equal to:

$$
M_{\text {har }}=\frac{\sum_{2}^{m} u_{i}+u_{j}}{E_{\text {com }}} .
$$

The indicator of harmony $M_{h a r}$ characterizes the strength of the informational unity of the relations of the dimensional structure of the architectural composition. The stronger the information connection of neighboring informational steps, the fewer informational modules are embedded in their total information. The more information per information module, the higher is the rate of harmony.

If we accept the position of A. Kolmogorov that information is a manifestation of complexity, then in formula (10) in the numerator we get the complexity. The informational unity of the architectural form is a consequence of its proportionality. Therefore, the total modular capacity $E_{c o m}$ in the denominator will characterize the degree of disorderliness of the architectural form.

Thus, the indicator of harmony is a function of the complexity and orderliness of the architectural form and can be considered as an informational interpretation of Eysenkck's aesthetic measure.

We are sure that any architect would like to check his subjective assessment with a quantitative one or quantitative (informational) assessment with a sensory one. To carry out such a check, we give an example of two compositions in the form of two rectangles with the 
same type of divisions, but with different ratios of the elements of the dimensional structure (Fig. 5).

They correspond to the informational fields below. In the center of each component and near the arrows are the informational steps of the relations of the elements of the dimensional structure, which can be checked using the formula (4). It should be mentioned that the logarithm of $\lg$ is decimal. We are showing the final result of the calculation: composition $A$ - an indicator of harmony $M_{\text {har }}^{A}=2$; composition $B$ - an indicator of harmony $M_{\text {har }}^{B}=3$.

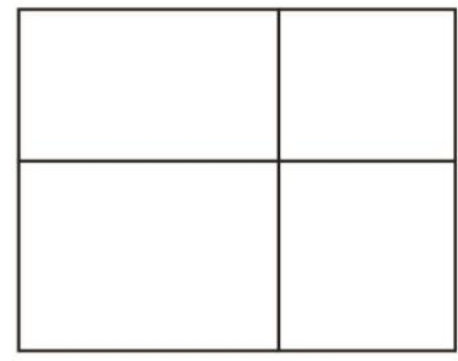

A

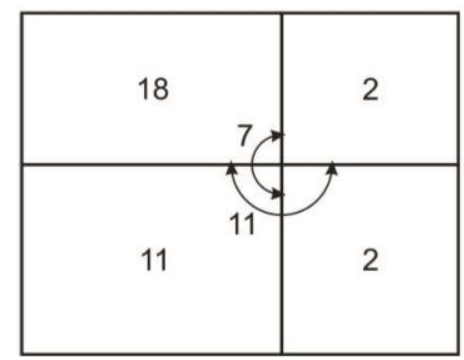

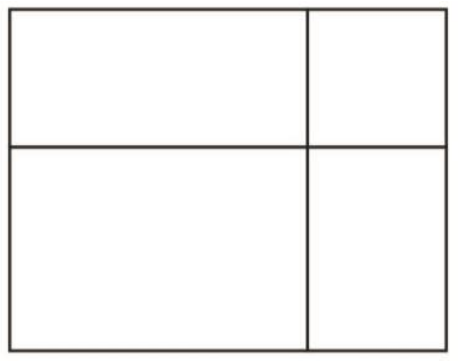

$B$

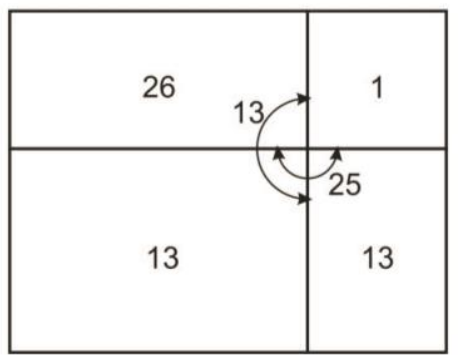

Fig. 5. Dimensional structure and informational field of planar compositions $A$ and $B$.

As you can see, composition B has a higher rate of harmony, despite the very small informational step of 1 eler in the upper right element of the composition. The high rate of harmony provided a strong informational connection of other parts of the composition based on the informational module of 13 (thirteen) eler. This figure is confirmed sensually. Most of the participants of the expert survey, who were asked to answer the question after presenting these two compositions: "Which composition in terms of comfort of perception do you prefer?" - responded in favor of the composition $B$.

Conclusion. In our research the informational method of the analysis of proportionality of dimensional structure of an architectural form and its demonstration on an 
example of information research of the Parthenon western facade has been offered. The results of this study are some unexpected discoveries:

- the visually perceived structure does not contain a "golden section" in relation to the visually perceived structure;

- the main unifying ratio of the dimensional structure is 1.35 , which corresponds to the informational step of 10 elers; it is the main "scraper" of the relations of dimensional structure, which provides the facade with the famous harmony;

- an extremely important role in the formation of the harmony of the Parthenon facade was played by the ratio of the overall dimensions of the facade (the level of the whole) and the intercolumn (the level of parts of the whole) - informational module of 25 eler (!);

- the proposed method of informational assessment of the harmony of the architectural form can be automated and used in computer design of architectural objects in case of software development.

\section{References}

1. Petrovich D. Theorists of proportions / D. Petrovich. - M. : Strojizdat, 1979. $193 \mathrm{p}$.

2. Messel E. Proportions in Antiquity and the Middle Ages / E. Messel. - M. : Kniga po Trebovaniyu, 2014. $-260 \mathrm{p}$.

3. Shevelev I. The Logic of Architectural Harmony / I. Shevelev. - M. : Strojizdat, 1973. $-188 \mathrm{p}$.

4. Mak-Uini G. Overview of Aesthetic Measurements // Semantics and Artmetry. M. : «Mir», 1972. - P. 35-49.

5. Negaj G. A. Distinctive Informational and Theoretical Model of the Dimensional Structure of the Facade Composition // Organization, methods and design technology. Abstract information TsINIS. Ser. XIII.- M. , 1976. - Vol. 1. - P. 17-21.

6. Negaj G. A. Informational Theory of Proportionality in Architecture // The state of modern building science 2006 / IV International scientific and practical Internet conference. Collection of scientific papers. - Poltava: 2006. - P. 225.

7. Alberti L. Ten Books on Architecture (in two volumes) / L. Alberti. - M. : Publishing House of the All-Union Academy of Architecture, 1935. - 392 (I), 792 (II) p.

\section{Translation of the References to the Author's Language}


1. Петрович Д. Теоретики пропорций / Д. Петрович. - М. : Стройиздат, 1979. $193 \mathrm{c}$.

2. Мессель Э. Пропорции в античности и в средние века / Є. Мессель. - М. : Книга по Требованию, 2014. - 260 с.

3. Шевелев И. Логика архитектурной гармонии / И. Шевелев. - M. : Стройиздат, 1973. - 188 с.

4. Мак-Уини Г. Обзор по эстетическим измерениям // Семантика и искусствометрия. - М. : «Мир», 1972. - С. 35-49.

5. Негай Г.А. Различительная теоретико-информационная модель размерной структуры фасадной композиции // Организация, методы и технология проектирования. Реферативная информация ЦИНИС. Серия XIII. - М. , 1976. - Вып. 1. - C. 17-21.

6. Негай Г.А. Информационная теория соразмерности в архитектуре // Состояние современной строительной науки 2006 / IV Международная научнопрактическая интернет-конференция. Сборник научных трудов. - Полтава: 2006. C. 225 .

7. Альберти Л. Десять книг о зодчестве (в двух томах) / Л. Альберти. - М. : Изд-во Всесоюзной академии архитектуры, 1935. - 392 (I), 792 (II) с. 


\title{
Diversity of Urban Buildings
}

\author{
Negai G.A. \\ Candidate of Architecture, associate professor, \\ Khmelnytskyi National University, Khmelnytskyi, Ukraine
}

\author{
Mashovets N.S. \\ Candidate of Technical Sciences, associate professor, \\ Khmelnytskyi National University, Khmelnytskyi, Ukraine \\ Strashko L.M. \\ Candidate of Architecture, associate professor, \\ Poltava University of Economics and Trade, Poltava, Ukraine
}

\begin{abstract}
This article considers the problem of diversity of the urban environment in terms of its visual (aesthetic) attractiveness. At the same time, the authors deliberately stepped away from the traditional views on diversity as a complex of a certain set of architectural forms and compositional means, regardless of the peculiarities of visual perception. The article considers the perception of urban development not as a static picture or frame, but in the process of movement. Movement, according to the authors of the article, is a source of detection and perception of spatial visual information, which makes the deep-spatial composition aesthetically attractive, shows its diversity. The criterion for assessing diversity has been offered - dynamic parallax, the speed of relative visual angular displacements of individual elements of the spatial structure during motion. Angular displacements are a source of dynamic perceived information - the basis of the diversity of buildings. It has been suggested that building on the basis of diversity alone can lead to chaos in development. According to the authors, it is necessary to combine monotony with diversity. The emotional potential of deep-spatial compositions, which provide smooth changes of informational flow has been substantiated, which is illustrated by the example of dynamic perception of the ensemble of the Round Square in Poltava (Ukraine).
\end{abstract}

Keywords: diversity, visual information, visual perception, motion in space, angle of perception, angular displacements, parallax, depth-spatial composition, ensemble of the Round Square, eler (elementary distinction).

Visual appeal of the urban environment of the period XIX - first half of XX century can be evaluated in different ways. First of all, it is an emotional assessment related to human scale and relative stylistic integrity. The architectural environment of those times was formed mainly by order architecture, brick or plastered, with constant cornice wall finishes and pitched roofs. Image-plastic expressiveness was achieved not only by the use of columned porticos, but mainly by window frames, window sills, brackets, various belts, niches, pilasters, rusts, stucco and sculptural elements, architectural details and so on. And, despite the fact that the buildings were designed by different architects, the urban environment was marked by 
stylistic unity, because it was their language, it was understood by all, it was clear to both creators and consumers.

All these elements of the architectural form are carriers of visual information of the architectural environment, which characterizes its complexity and order, which provide it with the necessary aesthetic appeal. But, these are not all informational characteristics which the variety of building of the modern city depends on.

We must not forget that architecture is not only the shape and plasticity of buildings, it is also the space in which the buildings are located; and our impressions of one or another part of the city are formed in the process of visual perception while moving in this space. Thus, movement is an important characteristic of the architectural environment. We often do not realize this, but only due to the natural instinct of knowing the form and space in our imagination is the image of the street on which we live, the image of the district, or the whole city. As the American architect Kevin Lynch wrote: "Clarity or readability is by no means the only important feature of a beautiful city, and when thinking about an environment with an urban scale of magnitude, time and complexity, it becomes especially important. To understand this, it is necessary to understand the city not just as a "thing in itself", but as a city perceived by its inhabitants "[1, p.7] (translated by V. Glazichev). Then K. Lynch adds: "... sound image of the environment gives an important sense of emotional comfort and helps to establish a harmonious relationship between the individual and the outside world." [1, p.7].

We cannot disagree with this thesis, because a harmonious environment cannot negatively affect a person. As a prominent politician of the $\mathrm{XX}$ century Winston Churchill said; "... first we create architecture, and then architecture creates us." The harmonious environment of a man, first of all - architecture, urban development, is not only a source of emotional comfort, but also is the basis for the harmonious development of the society. That is why it is so important to deal with some elements of human interaction with the urban environment.

First of all, we emphasize that the result of perception is visual information, the carriers of which are architectural forms and space. Facade architectural forms during the movement are perceived as a whole, regardless of the angle and speed of movement, due to the action of the psychophysical law of constancy of perception. But the space that separates individual buildings can be visually deformed and be a source of visual information that 
diversifies urban development. Let us consider this thesis on a specific, though, abstract example.

Figure 1 shows the visual perception of a fragment of urban development from a car moving at a speed of $36 \mathrm{~km} / \mathrm{h}$ or $10 \mathrm{~m} / \mathrm{s}$. The distance $(100 \mathrm{~m})$ between points $\mathrm{A}$ and $\mathrm{B}$ will be reached in $10 \mathrm{~s}$. The angle between the rays directed at objects $\mathrm{O}_{1}$ and $\mathrm{O}_{2}$ from the starting point $\mathrm{A}$ is about $15^{0}$. As the observer moves from point $\mathrm{A}$ to point $\mathrm{B}$, this angle will double and will be $\sim 300$. In addition, there will be relative angular displacements of the upper parts of the buildings $\mathrm{O}_{1}$ and $\mathrm{O}_{2}$ vertically. The picture of perception, as can be seen from Fig. 2 and 3, has changed significantly. In addition, as a result of the opening of the side façade of the $\mathrm{O}_{2}$ object, its secrecy disappears, the flow of visual information increases and, thus, the diversity of buildings is enriched. These changes that occur in the dynamics of visual perception due to relative angular displacements in the field of view are, in fact, parallax of motion. We called it dynamic parallax.
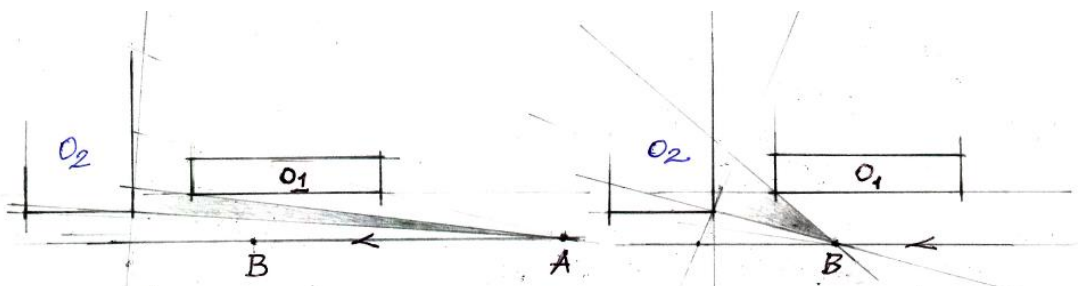

Figure 1. Visual perception of a fragment of urban development in the process of spatial movement.

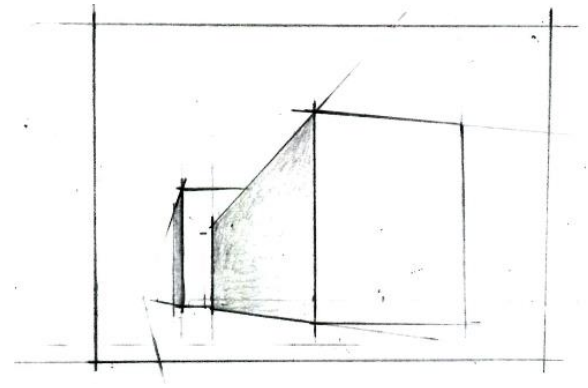

Figure 2. View of a fragment of urban development from point A.

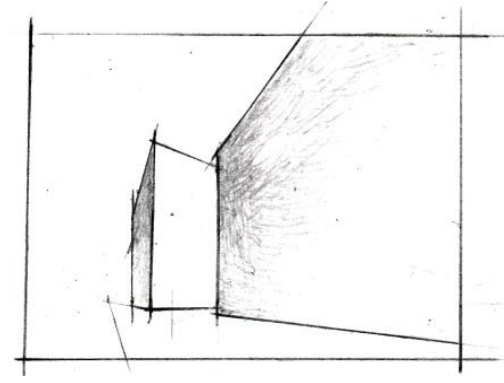

Figure 3. View of a fragment of urban development from point B.

Dynamic parallax can be used as a criterion for assessing the diversity of urban development. Its value depends on the speed of movement and the distance between the points of the deep-spatial composition, which we perceive in the process of spatial movements, as well as on the distance of these points to the observer moving in this space. Dynamic parallax 
gives the observer new visual information about the perceived depth-spatial composition. This information can be determined by the formula $u=k \ln \frac{r_{i}}{r_{j}}$ [2], where the numerator $r_{i}$ is a larger angle in degrees or radians, and the denominator $r_{j}$ is a smaller angle to obtain a positive value of visual information. The coefficient $k$ depends on the sensitivity of the visual system to the distinction of angular characteristics. The amount of visual information will be measured in eler - the number of elementary alignments between the angles. The angle of perception is considered as an element of the dimensional structure of the spatial composition. The coefficient $k$ can be determined in accordance with Weber-Fechner's law [2]. With the sensitivity of the visual system when distinguishing angles, as well as when distinguishing linear dimensions, $c=1 / 33$ the value of the coefficient will be equal to 76.56 at the decimal logarithm.

To calculate the informational flow in pedestrian traffic, you can set the sensitivity $\mathrm{c}=$ $1 / 25$, at which $k=50$, so it will simplify the calculations.

Since it is possible to assess the diversity of urban development, the question of rationing this characteristic may be raised. To do this, it is necessary to conduct large-scale informational studies of the diversity of many cities around the world, in parallel with their expert assessment, to study the optimal indicators of diversity. But let us dare to suggest that all-encompassing diversity can turn into chaos. In order for this not to happen, it is advisable to make periodic changes in monotony and diversity, to achieve an emotional outburst in the transition from monotonous to diverse buildings. In this case, we will become participants, as K. Lynch wrote [1], of this unique and unsurpassed "performance", created according to the script of the architects.

The change of spatial pictures that occurs during the movement can be illustrated by an example of the dynamic perception of the construction of the Round Square in Poltava (Ukraine) (Fig. 4).

This ensemble was created in the early XIX century. The diameter of this urban circle is $330 \mathrm{~m}$. In a circle there are buildings with a height of mostly 3 floors. However, this height, as it turned out, was not enough to balance such a huge space, to make buildings large-scale to it. Therefore, to alleviate this defect, at the end of the XIX century the Round one was planted 
with trees and later turned into a park, the alleys of which were used for military training of cadets of the Cadet Corps. Due to this, the park was named - Corpus Garden, which has survived to this day. During the existence of the Corpus Garden, its trees have grown and become large-scale with the construction of the ensemble.
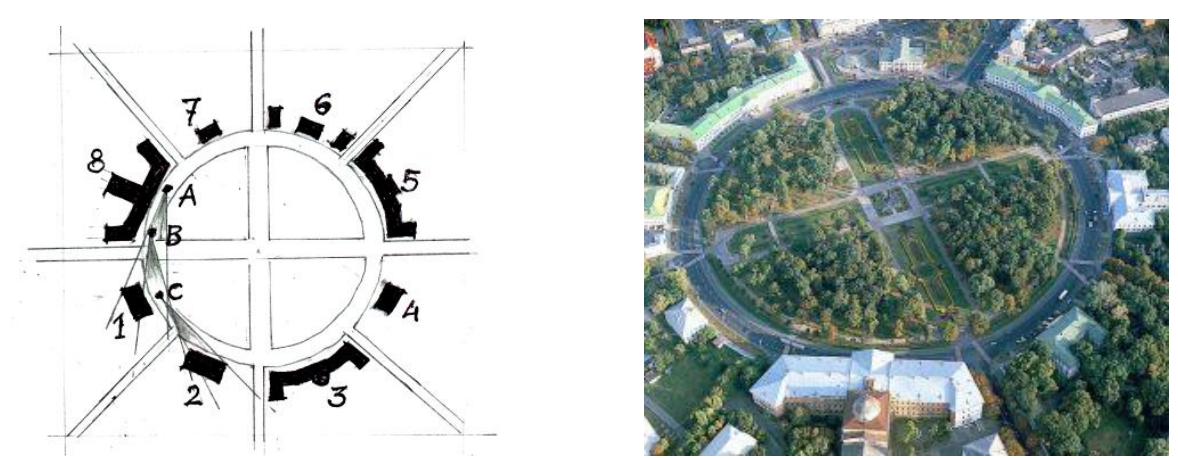

Figure 4. Round Square in Poltava (Ukraine): 1- Governor-General's House, 2 Poltava Provincial Post Office, 3 - Modern Post Office, 4 - Noble Assembly, 5 - Provincial Presences (government institutions, now Poltava City Council), 6 - Old Governor's House, 7 Vice-Governor's House, 8 - Petrovskyi Poltava Cadet Corps.

But at the same time a holistic perception of the ensemble became impossible, the trees cover the building. It is perceived only in fragments while driving in a counterclockwise direction, according to the rules of the road in force in Ukraine.

Consider step by step the perception of the ensemble of the Round Square. First, from position A, we perceive the house of the governor-general (Fig. 5). The next building is the Poltava Provincial Post Office, hidden behind the trees of the Corps Garden. As we continue to move along the ring, the side façade of the Provincial Post Office gradually opens up to us (position B, Fig. 6), and the main façade of the Governor-General's house gradually emerges from view. Finally, when we move to position C (Fig. 7), the main facade of the Poltava Provincial Post Office opens completely and the buildings of the modern Poltava Post Office and the Noble Assembly are expected to appear from behind the trees of the Corps Garden. As we move around the Corps Garden, a certain mystery of hidden space behind the trees of the Garden awaits us. Gradual unfolding of the mysterious space in accordance with the law of the instinct of expectation and knowledge of the new in the field of view, there is an emotional outburst from the perception of new information. This phenomenon of constant change of species frames in the process of movement creates the impression of spatial music, when the 
next element of space, like the next chord or note of a piece of music, is a source of positive emotion. Dynamic parallax as a consequence of the visual perception of the ensemble of the Round Square in the process of movement is a vivid example of the emotional and informational potential of urban development.

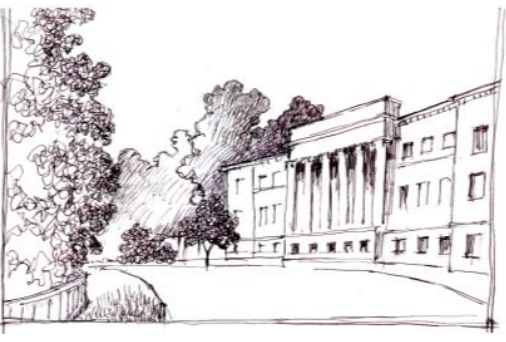

Figure 5. Governor-General's house

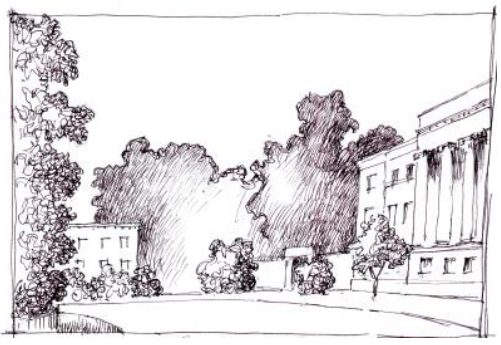

Figure 6. View towards the Poltava Provincial Post Office.

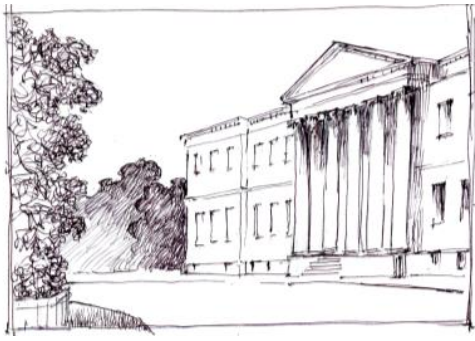

Figure 7. Poltava Provincial Post Office.

Another important component and potential of the diversity of urban development is the use of curvilinear elements, streets, buildings, facade compositions. This topic requires a deeper theoretical consideration, which we plan to carry out in the future.

Conclusion. The diversity of both urban and architectural forms, of our entire environment, has the same significance for the development of society as economy, fine arts, music, and so on.

Thus, the idea of a normative approach to solving the problem of uniformity of construction of new urban areas, which will also grow with the population growth, has come up. And, in our opinion, at the state level it is necessary to pay attention to the problem of improving the compositional and visual characteristics of urban development, so that it is easy for a person to navigate, and enjoy moving in an architectural environment, and develop as a harmonious personality.

\section{References}

1. Kevin Lynch. The image of the city. Moscow: Stroyizdat, 1982.

2. Negay G.A. Distinctive informational and theoretic model of the dimensional structure of the facade composition / Organization, methods and design technology. Abstract information. Series XIII. - M., 1976 - Issue 1. - P. 17-21. 


\title{
Some Legal Aspects of the Circulation and Research of Narcotic Drugs and Precursors
}

\author{
Kofanov Andrii \\ Legal Advisor to the Council of Europe Programme "Decentralization and \\ Territorial Consolidation in Ukraine”, PhD of Juridical Sciences, Associate \\ Professor, Professor of Department of Forensic Support and Forensic \\ Expertise of the National Academy of Internal Affairs, Kiev, Ukraine \\ ORCID ID 0000-0002-5242-2518 kofanov_andrey@ukr.net
}

\section{Pavlovska Nataliia}

PhD of Juridical Sciences, Associate Professor, Professor of Department of Civil Law and Process of the National Academy of Internal Affairs, Kiev,

Ukraine ORCID ID 0000-0003-3311-0364 wwwpav@gmail.com

\section{Svoboda Eugenia}

PhD of Juridical Sciences, Associate Professor, Professor of Department of Forensic Support and Forensic Expertise of the National Academy of Internal

Affairs, Kiev, Ukraine

ORCID ID 0000-0002-8639-8333 jeechka@ukr.net

\section{Symchuk Anatolii}

Senior Teacher of Forensic Support and Forensic Expertise of the National Academy of Internal Affairs, Kiev, Ukraine ORCID ID 0000-0002-8663-8210 symchukas@gmail.com

\section{Yakovchuk Serhii}

Associate Professor of Fire Training of the National Academy of Internal

Affairs, Kiev, Ukraine

ORCID ID 0000-0001-7066-3860 Yakovchuk_sergiy@ukr.net

\footnotetext{
Abstract

An analysis of criminal law practice suggests that when considering criminal proceedings of various categories (homicide, rape, theft, production, acquisition, storage, transportation and sale of drugs, etc.),
} 
material evidence is often represented by narcotic drugs of both illicit manufacturing and those produced by the pharmaceutical industry.

Narcotic drugs are a group of pharmacologically active substances of plant and synthetic origin that can selectively affect the central nervous system, resulting in the complete loss of consciousness, loss of all types of sensation and relaxation of skeletal muscles (anaesthesia), or a special psychological and physiological state of the human organism, at which the absence of the habitual poison (drug) causes a number of disagreeable sensations requiring periodic drug use [1].

This reaction is explained by the fact that drugs are quickly included in the metabolism and become indispensable to life. Meanwhile, they are not called poison for anything, since they lead to the physical weakening of the organism, and then to inevitable death. Drug use causes the development of drug addiction (from the Greek narke - sleep, numbness and mania - passion, mania) is clearly recognized morbid impulse and addiction to drugs that produce pleasant sedation or agitation (and some drugs - also illusions and hallucinations) followed by the central nervous system depression.

Keywords: narcotic drugs, cannabinoids, quinine, atropine, cocaine, opium alkaloids, strychnine, caffeine, theobromine, platyphyllin, scopolamine, ephedrin, homicide, rape, theft, production, acquisition, storage, transportation and sale of drugs.

\section{Introduction}

So, drugs provoke drug abuse both of a psychological nature (in their absence, the drug addict feels emotional discomfort) and of a physical one (in the absence of drugs, pain occurs due to dysfunctions of some systems till death). The activities of the human being with drug abuse are maintained at a certain level only on condition of the constant narcotic drug usage; therefore, the drug "seeking" gradually turns into the major goal of the drug addict. Inevitably faced with financial problems, drug addicts commit serious crimes in order to defraud funds for the purchase of drugs [2].

Narcotic effect commonly found in many substances, including such widespread ones as nicotine and alcohols (ethyl alcohol). The most pharmacologically active of these substances are classified by the Single Convention on Narcotic Drugs (UN, 1961) as narcotic substances. Amendments to the Single Convention, introduced in accordance with the 1972 Protocol, the 1971 Convention on Psychotropic Substances, the UN Convention against Illicit Traffic in Narcotic Drugs and Psychotropic Substances (1988) were ratified by Ukraine. The list of narcotic drugs, psychotropic substances and precursors subject to special control in accordance with the legislation of Ukraine is approved by the Cabinet of Ministers initiated by the Narcotics Control Committee. There are certain differences in similar lists of different countries pertaining to the certain national peculiarities.

In 1995, the Verkhovna Rada of Ukraine adopted the Law "On the Circulation of Narcotic Drugs, Psychotropic Substances, Their Analogues and Precursors”. In 1997, the Department on Combating Illicit Drug Trafficking (UBNON) was established in Ukraine. 
The National Coordination Council for Combating Drug Addiction under the Cabinet of Ministries of Ukraine was in operation [3].

Drug abuse, despite the active development of international cooperation in the combating against drug addiction, assumes literally catastrophic dimensions almost across the globe [4].

\section{Subject and tasks of the forensic examination of narcotic drugs}

The subject of the forensic examination of narcotic drugs is the determination using special knowledge of the facts and circumstances of the criminal event, for which the following tasks are solved: identification of narcotic drug traces on various objects-carriers, except for the human and animal body tissues and organs, as well as waste products of the living organisms, which are the objects of forensic (toxicological) examination; classification of substances as narcotic, indicating their name; establishing the common group belonging of the homogeneous narcotic drugs according to the raw material characteristics, the technology of their processing, storage conditions, etc.; establishing the common source of narcotic drug origin according to their manufacturing place and method; identification of specific masses of narcotic drugs in their individual parts; determination of the method, technology and characteristics of the narcotic drug manufacturing. To classify narcotic plants as a certain class or species, a forensic biological examination is provided. The compliance of the composition, quality of a pharmaceutical product having narcotic or psychotropic action with the requirements of the standards should be established by qualified pharmacists within the framework of a forensic medical examination [5].

The solution of such questions may be put before the forensic expertise of narcotic drugs: 1. Is the substance submitted for examination narcotic? 2. What type of narcotic drugs does the object of examination belong to? 3. Are there any adherings (traces) of narcotic drugs to the objects, the suspect's clothes provided for examination? 4. Are there traces of narcotic substances in the saliva, adherings to the suspect's hands and face? 5. Do the objects under examination have a common source of origin? 6. Did the narcotic drug provided for examination previously belong to this (specific) mass? 7. How is this narcotic drug manufactured?

\section{Objects of forensic examination}


It is advisable to group the objects of forensic examination of narcotic drugs in the following manner: clandestine produced narcotic drugs, extracted from the opium poppy, hemp, as well as from other narcotic plants; illicit synthetic and semisynthetic substances that do not belong to pharmaceutical products, and therefore, their use is prohibited; pharmaceutical products classified as narcotic, including hypnotics and psychotropic substances; whole narcotic plants and their parts; substances camouflaged as narcotic drugs; object-carriers with traces of narcotic drugs, including tools for their clandestine production; precursors.

It should be remembered that mixtures of various narcotic drugs or narcotic drugs with non-narcotic substances may also be provided for examination.

It is advisable to characterize the objects of forensic examination of narcotic drugs that are most widespread in Ukraine [6].

These are, first of all, clandestine produced narcotic drugs obtained from the hemp and opium poppy.

Hemp (cannabis) is a herbaceous, annual, wind-pollinated plant of the mulberry family. Male plants (fimble) have a thin stem compared to more branched female plants (pistillate hemps). In the narcotic drug manufacturing, the upper (apical) leaves and inflorescences (the apical inflorescences) are typically used, which have the greatest amount of active narcotic substances; however, narcotic drugs can also be obtained from leaves, chaff and other wastes from threshing or mechanical harvesting of hemp. Cannabis narcotic drugs are the most widely used drugs in the world.

Cannabinoids are biologically active components of hemp, as well as of narcotic drugs made from them, and are organic matters, a group of terpenic compounds (with their content up to $10 \%$ or more, depending on the type of narcotic drug): Cannabinol (CBN); Cannabidiol (CBD); Tetrahydrocannabinol (THC) and some of their acid derivatives.

The main component responsible for the psychoactive properties of the cannabis plant is THC, a psychotropic substance and a powerful hallucinogen. The content of cannabinoids in hemp depends on their variety, growing region, harvesting terms and methods, and storage conditions.

Clandestine produced cannabis narcotic drugs: Cannabis (marijuana) is any part of the plant with various degree of particle fineness: tops, inflorescences, leaves or their mixture 
with stems (excluding dead-ripe seeds). It has a spicy odour. It can also be used as a raw material for the production of other drugs from hemp. The colour is from light green/green to brown/deep brown; Cannabis resin (slang - hashish) is obtained, as a rule, from the cannabis plant tops by special grinding, sieving and pressing. Hashish can be found both in resinous and in the powdered or compressed state - in the form of lumps, balls, briquettes, slabs of bright green to deep brown colour with a characteristic spicy odour. The microscopic features of the plant are preserved. On the surface of compressed objects, there are imprints of fabric, traces of moulds; Extracts (tinctures) of cannabis or hashish oil, liquid cannabis, liquid hashish is obtained by extraction of cannabinoids using various solvents (gasoline, hexane, alcohol, etc.) or fats (milk), followed by the solvent removal (evaporation). It is oily from brown to almost black liquid of various consistencies with the characteristic odour of solvent. Sometimes tobacco products are impregnated with it, and then the tobacco particles stick together, and their colour becomes dark brown, and coloured spots appear on the paper wrapper.

The same group of clandestine produced narcotic drugs of plant origin include drugs produced from the opium poppy.

The opium poppy is a type of poppy, among which oily and opium forms are distinguished. Despite certain differences, both forms, more or less, contain narcotic substances. The alkaloids of the opium poppy - opium alkaloids - have narcotic properties. It should be noted that alkaloids are nitrogenous physiologically active organic compounds of predominantly plant origin: quinine, atropine, cocaine, opium alkaloids, strychnine, caffeine, theobromine, platyphyllin, scopolamine, ephedrin, etc.

The following drugs are made from the opium poppy using the clandestine production: Opium (slang - ope) is latex, which leaks out from the incisions of the immature poppy seedpods, and then dries out (in the air, the sun, etc.). It occurs as a dark resinous mass, powder, lumps, balls, tiles, cakes or tinctures that bitter to the taste. About $25 \%$ of opium is made up of so-called opium alkaloids (they have more than 25 names). The main ones are morphine (about 10\% of opium), codeine, thebaine, as well as narcotine, papaverine, narceine, which exist as salts of meconic, sulfuric, and lactic acids. In addition to alkaloids, opium also contains proteins, resins, rubber, carbohydrates, fatty acids, mineral salts, and other substances; Raw opium (slang - beast heroin) is latex, which leaks out from 
the incisions of the immature poppy seedpods, and then clots, without additional drying or processing. It has grey-brown colour and peculiar unpleasant odour; Poppy straw, which includes all parts of the mowed opium poppy (dried or not dried), except for seeds. It comes for examination as components of the opium poppy plant, including whole or ground pods, sometimes in a compressed form. Their grinding degree is different; Concentrate of poppy straw (extraction opium, poppy straw extract) is obtained by extracting opium alkaloids using boiling water or organic solvents (alcohol, acetone, and toluene) and evaporating the extracts to resinous condition. It has deep brown colour and dried fruit odour; Acetylated opium is obtained by acetylation of the opium or poppy straw concentrate. It contains acetylated derivatives of morphine, codeine or their mixture.

In Ukraine, a peculiarity of the acetylated opium clandestine production technology is the use of small amounts of acetic anhydride, as a result of which the acetylation reaction sometimes does not reach the end; therefore, in addition to diacetylmorphine (heroin itself), the drug contains morphine, monoacetylmorphine, and acetylcodeine. In recent years, acetylated opium is called heroin in Ukraine. The most common illicit synthetic and semisynthetic narcotic drugs that do not belong to pharmaceuticals, and, therefore, prohibited to use, are as follows: Heroin (diacetylmorphine) is a synthetic derivative of morphine, of white colour, in the form of amorphous or crystalline powders or granules. In most cases, it is not a chemically pure substance, but a multicomponent mixture with monoacetylmorphine, acetylcodeine, morphine, of beige, brown or black colour. Lactose, glucose, quinine, corn starch, barbiturates, novocaine, and caffeine are often added to heroin. It is packed in the cellophane film ("balls") or aluminium foil to protect against moisture; LSD (lysergic acid diethylamide) is made from lysergic acid, a substance isolated from ergot (a fungus that infects cereals and most often parasitizes on the rye spikes). LSD is a psychotropic substance, a hallucinogen. It occurs as a colourless and tasteless liquid or offwhite powder, tablets, or capsules. The liquid is applied to prepunched paper("stamps"), dripped onto sugar; Cocaine (slang - snow) is a white light crystalline powder, odourless, like snow. The poorly purified (grey), the compressed form also occurs; "Crack” (cocaine base) is a super drug derived from cocaine. The "crack" sound is produced when crystals are heated. Pieces of brown, yellow, pink or white colour, small, hard, semi-translucent, similar to laundry soap, grind and smoke with glass pipes, mix with marijuana or tobacco; 
"Speedball" is a mixture of "crack" and heroin; Ephedrone (slang - tweeker) is colourless, light-yellow, yellow, brown, sometimes red liquid, which is obtained from ephedrine or pseudoephedrine - an alkaloid of the Mongolian ephedra shrub or a synthetic analogue. It has a bitter almond odour; MDMA (3,4-methylenedioxymethamphetamine, slang - ecstasy, wheels) from white to light brown powder, tablets or capsules of different colours. The tablets contain an embossed pattern (bunnies, elephants, camels, etc.). Sometimes drinks are made from it.

The third group consists of pharmaceutical products classified as narcotic.

These are, first of all, opiates - pharmaceuticals obtained from opium, containing the main opium alkaloids and their synthetic substitutes: Omnopon is opium, partially purified from ballast substances. It contains $50 \%$ of morphine and up to $35 \%$ of other alkaloids. It is used as a cream to brown-yellow powders or colourless or brown-yellow solutions; Morphinum (slang - morph). Such pharmaceutical products as morphine hydrochloride, ethylmorphine hydrochloride and others are manufactured in the form of capsules, tablets, white powders, and solutions - in ampoules or syringe-tubes. The technical morphine is not a dosage form. It is made by clandestine production; Codeine is a pharmaceutical represented by a white powder "codeine phosphate"; Promedol is a synthetic medicine of morphine-like action in the form of white tablets (powder), colourless solutions in ampoules or syringe-tubes ( $1 \mathrm{ml}$ each); Methadone is chemically different from morphine but similar in action. For several decades, it has been widely used in the foreign treatment programmes for detoxification of the patients with heroinomania. It is an oral drug substitute. The analogues of the aforementioned and other opiates are sometimes illicitly manufactured in the clandestine laboratories [7].

In recent years, psychotropic and hypnotic drugs of narcotic action from the List $B$ of superpotent substances have been illegally used, which are as follows: Hypnotics of narcotic action are primarily barbituric acid derivatives - barbiturates; although there are more than 2500 barbiturates (in the form of tablets, powders, and solutions), in Ukraine, barbital, sodium pentobarbital (nembutal), cyclobarbital, phenobarbital, benzonal, and hexamylene are most often found in illicit trafficking. Drug addicts also use hexenal, noxyron, sombrevin, which are used in medical practice for the non-inhalation anaesthesia; Psychotropic agents, which make up a group of medications with a specific action on the 
psychic state. Unlike narcotic drugs, they are able to regulate the altered psychic state, and not just influence on it; therefore, they are used to treat psychiatric illnesses. Sedative (psycholeptic) drugs include aminazin, and stimulating agents (psychoactivators) - so-called amphetamines: phenamine, pervitin, phenatin, etc., as well as clophelin. The pharmaceutical product "amphetamine sulfate" is represented as white powders or tablets. The clandestine produced amphetamines are white, pink, yellow, brown, often wet powders or tablets, which have an unpleasant (characteristic) odour due to the residues of organic impurities.

The narcotic plants, which make up the next classification category, include, first of all, various species of hemp and opium poppy [8]. Interestingly, the cultivation of opium poppy plants for seed production is allowed only if the morphine content in the dried straw is not more than $0.15 \%$, and hemp plants - provided that the THC content in the dried straw is not more than $0.15 \%$.

In the countries of Central Asia and in the Crimea, Mongolian ephedra containing the precursor ephedrine grows. Among the exotic plants, it should be noted the coca bushes (coca), cola trees, as well as betel shrubs, mate trees, some types of cacti, mushrooms, etc. It should also not be overlooked that alkaloids are found in tea leaves (caffeine, theobromine, etc.), tobacco (nicotine), and coffee beans (caffeine). Although alkaloids are found mainly in leaves, sometimes in seeds, fruits, roots; therefore, various parts of the plant are used for the clandestine production of drugs.

Substances camouflaged as narcotic include those used to "dilute" drugs or to falsify them. These are, first of all, tobacco, dry nettle, dry fishfood, spongilla, basma, henna, balsam, mummijo, "naswar", and others.

Precursors are substances and their salts classified in international conventions as chemicals used for the manufacture of narcotic drugs and psychotropic substances, as well as chemicals and their salts used for the same purpose and classified in this category by the Drugs Control Committee [9].

The most common precursors should be considered potassium permanganate, crystalline iodine, "red phosphorus", acetic anhydride $(\mathrm{pH}=7)$, inorganic acids (sulfuric, hydrochloric) and organic solvents (acetone, toluene, diethyl ether), various medications (sunoreph, broncholytin, theophedrin, solutan containing ephedrin), and others [10]. 
Conclusions So, the most common object-carriers with traces of drugs are as follows: clothing and human body (especially hands and face); drug taking instruments: syringe, needle, tourniquet, paper tubes for inhaling cocaine, spoons, and empty packages of drugs; tools for clandestine production designed for processing plants and making extracts (coffee grinders, grinding machines, mortars, sieves, moulds, pots, knives, scrapers, fabrics, bandages, cotton pads, especially if they have a characteristic green or brown "grassy" powdery coating), as well as laboratory ware for the distillation, purification and synthesis of drugs.

\section{References}

1. Criminal investigations of narcotic drugs. URL : http://elar.naiau.kiev.ua/jspui/handle/123456789/2990

2. Expertise in judicial practice: scientific and practical textbook. / Under general edit. by V. H. Honcharenko. - [2nd ed., revised and enlarged]. - K. : Yurinkom Inter, 2010. $400 \mathrm{p}$.

3. Moiseenko I. Ya. Commissioning of forensic examinations in the investigation of crimes related to narcotic drug trafficking / I. Ya. Moiseenko // Bulletin of Perm University. - 2010. - No. 2 (8). - P. 198-206.

4. Dovhan A. A. From the experience of the Netherlands Forensic Institute / A. A. Dovhan // Expert and forensic support for the detection and investigation of crimes: practice, experience, problems / Under general edit. by I.P. Krasiuk. - K. : State Research Expert \& Forensic Centre of the MIA of Ukraine, 2010. - Issue 17. - P. 25-30.

5. Koldin V. Ya. Investigative and expert situation as a basis of information interaction between a criminal investigator, an expert and a specialist in the investigative proceedings / V. Ya. Koldin // Forensic examination. Scientific and practical journal. Saratov : Publishing house of the Saratov Law Institute of the MIA of the RF, 2005. - No. 2. - P. 12-18.

6. Law of Ukraine "On Counter the Illicit Trafficking of Narcotic Drugs, Psychotropic Substances and Precursors and Their Abuse", No. 62/95-VR, dated 15.02.1995. - Electronic resource. - Access mode: http://zakon3.rada.gov.ua/laws/show/62/95\%D0\%B2\%D1\%80.

7. Puptseva A. V. Peculiarities of the expert examination performance at the initial stage of the investigation on crimes related to the illicit traffic in narcotic drugs and psychotropic substances / A. V. Puptseva // Gaps in Russian legislation. - 2009. - No. 1. - P. 236-237.

8. Klevtsov V. V. The use of special knowledge in the investigation of crimes related to the illicit traffic in narcotic drugs and psychotropic substances: monograph / V. V. Klevtsov, S. A. Tishkov. - Orel : OrLU of the MIA of the RF, 2012. - 158 p. 
9. Kogosov A.P. Forms of using special knowledge in the investigation of crimes related to the illicit traffic in narcotic drugs or their analogues: [monograph] / A. P. Kogosov, A. V. Petrov. - M. : Yurlitinform, 2012. - 200 p.

10. Strigun D. Yu. Technical and forensic provision for the detection and investigation of the illicit drug trafficking: thesis for a Cand. Degree in Law Sc. in the spec. : 12.00.09 - criminal procedure and forensic science; forensic examination; investigative activities / D. Yu. Strigun. - K. : NAIA, 2011. - 279 p. 


\section{Modern Possibilities of Forensic Land and Soil Examinations Within the Civil and Criminal Law}

\section{Pavlovska Nataliia}

PhD of Juridical Sciences, Associate Professor, Professor of Department of Civil Law and Process of the National Academy of Internal Affairs, Kiev, Ukraine ORCID ID 0000-0003-3311-0364_wwwpav@gmail.com

\section{Kofanova Olena}

PhD of Juridical Sciences, Associate Professor of Forensic Support and Forensic Expertise of the National Academy of Internal Affairs, Kiev, Ukraine ORCID ID 0000-0002-0919-7570 kofanova alena@ukr.net

\section{Kulyk Maryna}

PhD of Juridical Sciences, Associate Professor of Forensic Support and Forensic Expertise of the National Academy of Internal Affairs, Kiev, Ukraine ORCID ID 0000-0003-1373-6749 coolss777@ukr.net

\section{Strilets Halyna}

PhD of Judicial Sciences, Associate Professor of the Departament of Law of

Prydunai Branch of Private Jointstock Company «Higher Educational Institution of Interregional Academy of Personnel Management», Izmail, Ukraine

ORCID ID 0000-0002-1067-0820 galinastrelets2018@gmail.com

\section{Filipova Natalia}

Asistant of the Departament of Law of Prydunai Branch of Private Jointstock Company «Higher Educational Institution of Interregional Academy of

Personnel Management», Izmail, Ukraine ORCID ID 0000-0001-7132-8343 filinatalja2310@gmail.com

\footnotetext{
Abstract

Forensic soil expertise is most commonly carried out in civil and criminal proceedings of the relevant issues. For this purpose, all types of soil formations, both naturally occurring and artificial, are used, wherein sometimes biological objects and human activity products (anthropogenic factor) constitute a major part. The
} 
multicomponentness and dynamism of soil-origin objects significantly complicate fulfilling the tasks set before expertise, including the fixation of its value. The problem of determining the classification category of forensic soil expertise remains controversial [1].

The subject of forensic soil expertise is factual evidences, circumstances of the case, established on the basis of special branches of knowledge: forensic science, forensic soil science and allied natural and engineering sciences: general soil science, geology, agrochemistry, and biology. Using the forensic soil expertise, a number of tasks may be solved by identifying: the fact that an object (subject) was in a specific location; the fact of contact interaction between any objects; the mechanism of soil adhering transference on various objects (clothes, shoes, household equipment, murder weapon or burglary tool, vehicle, etc.); spatiotemporal characteristics (time of individual soil layer transference, prescription of burial, etc.); certain negative circumstances, e.g., the noncorrespondence of the place of corpse discovery to the crime scene; the fact of environmental pollution.

Keywords: a general studies, i.e. a microscopic examination to identify various inclusions; determination of morphological characteristics; mineralogical study; study of the organic component; study of the biological component; analysis of the biochemical component of soils.

Introduction When commissioning forensic soil expertise, the solution of the following questions may be posed before it: 1 . What is the estimated cost of soils? 2. What is their recreational value? 3. What is the organic matter content? 4. What is the mineral content? 5. Are the soils contaminated with foreign substances? 6. Are there any soil adhering to the provided object-carriers, and what is their localisation? 7 . Whether the adhering found on the object-carrier are of soil-origin? 8. Are the provided soil samples suitable for identifying a specific location? 9. Did the soil adhering to the object-carriers previously belong to a particular location (place of murder, the discovery of a corpse, a vehicle)? Moreover, the location of a site, indicating its size and boundaries, is given; 10 . Does the soil have a characteristic composition indicating the source of its origin? 11. Were the objects provided for expertise in contact interaction, taking into consideration the adhering of soil microparticles to them? 12. What is the mechanism for the adhering formation? 13. What is the prescription of burial (contamination)? 14. Are the provided soil samples suitable for identifying a specific location?

The wording on the question concerning the homogeneity or similarity of a number of soil samples is too equivocal: if the questioned samples are of soil-origin, then they are always somewhat similar, and some part of them may be homogeneous [2]. To identify the presence of soil adhering to the object-carriers, the expert needs at least $0.1 \mathrm{~g}(100 \mathrm{mg})$ of the investigated material, to determine the generic (species) belonging of soils - at least $0.2-1 \mathrm{~g}$. The signs indicating the common origin of soils compared are both their generic (species) belonging and group one. 
Generic (species) belonging is determined in accordance with the classification accepted in the soil science. The group belonging of soils is understood as the nature of their use: the state of cultivation, anthropogenic factors (technogenesis - amelioration, the application of chemicals, fertilisers), the nature of the land, etc. It is not always possible to determine the temporal characteristics. This is impeded not only by the variability of the investigated object properties, but also by the violation of the soil packing rules, poor storage conditions, and delay in delivery for investigation. There are absolute (based on the plant development stages and season-dependent zoophases) and relative (according to the degree of putrefactive process development, moisture) temporal characteristics. In order to determine the place of origin of the soil adhering, palynological and diatom analyses should be used. The specifics of identification task solving during forensic soil examination deserves special attention [3].

The objects of the forensic soil examination are as follows: the topsoil of various locations, including the covering of basements, barns, garages, boiler houses, warehouse premises, partially constructed houses, backfilling of attics, walls; soil adhering to various object-carriers (items of clothing, footwear of a person, burglary tools, vehicles, etc.). The notion of an object of identification is highly specific for soils. It has been proved that soil adhering to the object-carriers sufficiently reflect the set of soil properties of the location from which they were transferred as a result of contact interaction. However, the question of "identity" or "equality" of different soils is incorrect methodically, since only a specific object can be equated. The fact of an object (suspect, vehicle) presence in a specific location from the point of view of the theory of forensic identification is considered as the identification of a specific location, which is carried out indirectly, i.e. through a comparative study of soil samples taken from this location and soil adhering from the object-carrier (the suspect's shoes, vehicle tire treads).

To identify a specific location, it is necessary to determine the degree of its individuality in relation to the neighbouring sites adjacent to it preliminarily, and to define its boundaries, i.e. to localise (concretising schematically and in the report) [4]. Localisation involves the demarcation of natural and/or artificial boundaries. The first is caused by naturally occurring factors and are linked to specific fixed relief features and vegetation (forest, meadow, river, gully, clove, etc.). The second is associated with human activities 
(embankment, vegetable garden, field, pit, etc.). If the site is localised, the belonging of the soil adhering to the object-carrier of this location is identified. If the crime scene is part of a territory that is relatively homogeneous in terms of soil and it cannot be localised, the task set before the expertise is to determine the general generic or group belonging of the soil adhering to the object-carrier (e.g., on the accused's clothes) and the soil from the crime scene. During the investigation of a road traffic accident (hereinafter referred to as RTA), soil particles left by the vehicle are found at the crime scene. In this case, the task of the expertise is the identification of a specific vehicle, which is carried out in a comparative examination of soil formations found on the road (or on the clothes of a hit pedestrian) and adhering that remained on the vehicle. In these cases, consideration must be given to the fact that soil adhering accumulate on the vehicle gradually, sometimes for a long time, when driving through locations with different topsoil. The set of features of the multi-layered formations in the presence of their unique complex allows identifying a specific vehicle [5]. Similarly, a comparative examination of soil particles, formations left by the subject's shoes on the object-carrier (in the footwear impression on the road, floor, windowsill, etc.), and soil adhering that remained on the subject's shoes is carried out. In this case, the object of identification is the subject's shoes. We shall consider the notion of reference and control soil samples. To conduct a comparative examination of the soil-origin substances, it is necessary to collect material evidence and soil samples.

Soil samples are divided into two types: reference samples (individual test portions), which are collected from the identification object (from a localised site, vehicle) or several suspected objects; control samples, taken to distinguish the object of identification from similar ones.

To demarcate the site that is identified, the control samples are taken from four sides outside it in the vicinity. Each control (mixed) soil sample consists of four to five samples taken within a radius of 5-10 $\mathrm{m}$ and packaged in one bag. If there are no natural or artificial boundaries of the site, i.e. there are difficulties in the visual localisation of the crime scene, samples should be taken at compass points and at a distance ranging from 25 to 200 metres (25-50-100-150 m) from the scene, without dividing them into reference and control. It is only possible to establish the degree of individuality and localise the crime scene with the help of control samples [6]. 
Thus, control samples allow establishing the degree of individuality of the identified object. If soil lumps were found on the roadbed, which probably separated from the vehicle at the moment of the accident, then reference samples are taken from different places of the suspected vehicle (from tires, bumpers, mud flaps, bridges). Control samples are collected from the road shoulder and from vehicles that have travelled the same route. If the subject's shoes are material evidence, the control samples will be taken from the place of residence, as well as the workplace of the owner of the shoes, to isolate from the entire mass of soil adhering that part, which does not concern the event [7].

There is a good reason to consider some options for a soil sample collection from a localised site. For example, the crime scene is a forest. The site localisation is carried out, taking into account the relief (slope, hill, gully, plain) and vegetation (its type or absence). These factors are clearly visible and in most cases, reflect the topsoil characteristics. The reference sample collection is carried out in a circle from the centre of the scene (4-5 samples from each). The number of circles is $2-3$, the distance between them ranges from 10 to 50 metres. The larger the site, the greater the distance should be between the circles. If the site is localised, control samples (4-5 pieces) are taken immediately outside of it, if not localised they are collected at 25-50-100-200 metres (in different directions).

If the crime scene is a meadow, localisation is easier because the vegetation characteristics can determine the degree of soil homogeneity. In this particular case, the vegetation characteristics depend only on the soil features, and in the forest, it is influenced by both illumination (the presence of trees, shrubs) and the relief pattern. Samples are collected in the same way as in the previous example. In both cases, plant samples should be taken from the crime scene. If this is a homestead plot or a vegetable garden, it is already localised by its own limits. Control samples are taken from an adjoining plot, a garden bed [8].

Such a crime scene as a basement of a house, an attic, a barn, a boiler house, or a partially constructed house is a clearly localised site, limited area within the frame of a building. Therefore, the localisation process involves dimensioning of the premises and describing its features: the presence of chambers and their number, dimensions; the cover surface colouring; the main components of the covering (sand, clay, brick, slag, other constructional materials); the covering condition (dry, damp, wet). The reference sample 
collection is carried out from different parts of the premises: directly from the crime scene, at the entrance to the premises, in each chamber, under the windows (one sample each). Control samples are taken immediately in front of the entrance to the basement, at some distance from the entrance (5-10 m) and similarly located ones near the premises.

If the crime scene is a flat, soil-contaminated household items (bedspreads, tablecloths, rugs), soil overlaying from the windowsill, from the floor (especially at the entrance to the premises, under the windows) are collected. As controls, samples are taken near the porch (communal entrance hallway), from the homeward path, or from the places where footwear impressions are detected in the sites located near the house. If the crime scene is the water bottom (lake, river), reference soil samples are taken from the bottom, the shore, near the drag marks, and control samples - from the opposite side of the reservoir, and if there is another reservoir nearby, then from it. Water samples are taken from the depth of the water reservoir. A road accident site is an object elongated longitudinally [9]. The road boundaries (moto roads, railways) are clearly defined transversely, but not longitudinally, therefore 4-5 reference samples are taken from the accident scene, and control samples are collected from the road shoulder, the right-of-way, the road itself at a distance of up to 200500 metres to one side and to the other from the centre of the accident scene.

If the crime scene is a pit, reference samples are taken from the surface at the edge of the pit, its bottom, walls, and control samples - outside the pit from sites with intact surface cover (from the surface and from a depth equal to the depth of the pit). Before collecting samples from the walls of the pit, one of them must be thoroughly cleaned of mixed soil. Then, samples are taken from the cleaned wall along the horizons, which are distinguished by colour, texture profile, assembly, and structure. If the soil is homogeneous throughout the profile and it is impossible to visually divide it into horizons, samples should be taken from a depth of 0-5, 10-15, 20-25 cm and so on down.

When digging a pit, the soil should be removed layer by layer, sifting it through a sieve with the holes ranging from $10 \mathrm{~mm}$ to $2 \mathrm{~mm}$ and noting what and in which layer was found (insects, plant remains, and other inclusions).

It is not allowed to mix reference samples from different horizons. On the packaging labels, it is necessary to indicate the sampling depth and horizon characteristics. Similarly, samples from the ravine are collected. 
The process of soil-origin object investigation may be divided into six stages: 1) a general studies, i.e. a microscopic examination to identify various inclusions (magnification $28 \mathrm{x}$ ); 2) determination of morphological characteristics; 3 ) mineralogical study (analysis of mineralogical components); 4) study of the organic component; 5)study of the biological component; 6) analysis of the biochemical component of soils.

The results of all investigation stages are summarised, defining the object's feature complex, which makes it possible, in particular, to localise the sites located at a distance of 50-100 m [10].

When describing plant particles, it is advisable to denote the plant type (herbaceous, arboreous), its part (lamina, stem, seeds, flower, bark, etc.), condition (fresh, faded, dry, at the stage of decomposition), and colour (green, brown).

Example: In soil samples from the crime scene and in the soil layer on the victim's clothes, experts found foreign inclusions - red, green and blue fibres. These fibres were the same as the fibres of the suspect's clothing and differed from the fibres of the victim's clothing. In addition, wood particles of coniferous species, characteristic of the crime scene, were found on the suspect's jacket. The set of established signs is individual. Not only the qualitative but also the quantitative composition of the inclusions can be specific. Example: The female corpse showing signs of violent death was discovered in a river on a littoral shelf. The suspect claimed that he parted from the victim at the bus stop and did not go beyond the highway. The determination of the soil morphological characteristics can be supplemented with the specification of: calcareousness; hygroscopic moisture content; $\mathrm{pH}$ value of the media. The hygroscopic moisture content is determined by drying the object (sample) to constant weight. The specified indicator depends on the texture profile and humus content. The method for determining soil calcareousness is not complex. A drop of $\mathrm{HCl}$ is applied to a glass slide, and portions of the soil substance are added to it. The reaction is observed in a magnifying glass (magnification 3.5x) and under a microscope. Depending on the calcareousness, boiling may be vigorous, weak, or absent altogether. It should be noted that the natural calcareousness is associated with the presence of limestones, mollusc shells, etc., the artificial one - carbonates $\mathrm{Ca}, \mathrm{Mg}, \mathrm{Mn}$, Fe, etc., introduced into the soil to improve fertility. 
The mineralogical study is carried out after separating each sample into clay and sandy fractions. The essence of the method of soil texture determining lies in the fact that both fractions are present in various proportions in almost all soils and their ratio is taken into consideration when the texture of the investigated samples is assessed. The geologicalmineralogical analysis is based on the soil sandy fraction stud, i.e. the physical, chemical and optical properties of minerals. The petrographic analysis is intended for the study of soil in thin sections, where the content and relative position of various components is determined. The identification and differentiation of soil samples by trace elements, which are rare in minerals, is performed by means of the emission spectral analysis. Luminescence analysis is sometimes used to diagnose minerals.

Then the organic component of the soil is investigated. The majority are humic substances, formed in the process of complex transformations of plant and animal residues. The elemental composition of organic substances, which is represented by C (50-60\%), H (3$6 \%), \mathrm{B}(30-40 \%), \mathrm{N}(2-6 \%)$, as well as $\mathrm{P}, \mathrm{S}, \mathrm{Se}, \mathrm{Fe}, \mathrm{Al}$ in certain proportions, is determined by the method of organo-elemental analysis. Electrophoresis and paper chromatography is used for the comparative study of the so-called humic acids - a complex mixture of organic substances of various compositions. Fractionation of humic acids is carried out by these methods. This permits to distinguish soil types using electrophoregrams and chromatograms by the number of zones, their location, colour intensity and the nature of the luminescence in UVS and visible light. The method for the ignition loss determining is indicative of the humus content in the soil. It is simple and express: ignition is carried out to constant weight. The IR spectroscopy method gives information about the atomic groupings that characterise the carbon skeleton of organic molecules, as well as about the functional groups in the molecules of humic substances. Spectral luminescence analysis according to the Shpolsky method makes it possible to identify polycyclic aromatic hydrocarbons (PAHs) in soils, which enter the soil with waste from industrial enterprises and transport. Qualitative and quantitative PAH spectra are used to differentiate soils.

The next step is to study the biological component of the soil: zoological, botanical, microbiological, palynological and diatom analyses, and the analysis of other single-celled algae. The palynological analysis involves determining the ratio of various pollen and spore types in the soil. Diatom analysis is effective in identifying reservoirs or wetted areas of soil 
since diatom algae - lower algae - exist in conditions of high moisture content. For these tests, 1-5 $\mathrm{g}$ of soil is enough.

Biochemical studies are presented by determining soil enzymatic activity.

Conclusions Thus, the local site must be considered as an element of the material situation of the accident, which was formed and exists under the influence of a large number of natural and random factors and is, therefore, characterised by a unique set of features, which creates significant opportunities for its identification [11]. It should be considered that the soil composition of the adhering may not be fully represented, since heavy coarse grains drop off, and small ones remain. The properly performed sample collection and the correct determination of the object of identification contribute to the efficiency improvement of soil examination to obtain both evidence and criminal intelligence information.

\section{References}

1. Forensics: Higher education textbook. / Edited by P.D. Bilenchuk. - K.: Pravo, 1997.

2. Averianova T.V., Belkin R.S., Korukhov Yu.H., Rossinskaia Ye.R. Forensics. Higher education textbook / Edited by R.S. Belkin. - M., 1999.

3. Fundamentals of Natural Science for Lawyers: Higher education textbook on the course "Concepts of Contemporary Natural Science" / Edited by E.R. Rossinskaia. - M., 1999.

4. A forensic examination of soil. A forensic examination of soil. URL: http://elar.naiau.kiev.ua/jspui/handle/123456789/1709

5. Forensics: Textbook for stud. of spec. Law universities / Edited by V.Yu. Shepitko. - K., 2001.

6. Forensics: Textbook. / Edited by P.D. Bilenchuk. - 2nd ed., revised and enlarged - K.: Atica, 2001. - 544 p.: il.

7. Saltevskyi M.V. Forensics (in the modern presentation): Textbook. - K.: Condor, 2005.

8. Kofanov A.V. Features of expert errors and some ways to prevent them during forensic ballistics examinations / Criminalistics and forensic examination: interdepartmental methodological collection / Ministry of Justice of Ukraine, Kyiv Scientific Research Institute of Forensic Expertise. - K., 2015. - Issue 60. - P. 275-287.

9. Kofanov A.V. Some aspects of the problematics of training forensic experts, their interaction with the executive management and their investigation evaluation / Forensic bulletin: scientific and practical collection / [Chief Editor V.V. Cherniei] / State Research Expert \& Forensic Centre of the MIA of Ukraine; NAIA. - K.: PC "Typography from "A" to "Z", 2013. - No. 2 (20). - P. 107-116.

10. Kofanov A.V. Disadvantages of psychological and legal (professional) training of a forensic expert as a prerequisite for the occurrence of expert errors / Forensic bulletin: 
scientific and practical collection / [Chief Editor V.V. Chernei] / State Research Expert \& Forensic Centre of the MIA of Ukraine; NAIA. - K.: PC "Typography from "A" to "Z", 2015. - No. 1 (23). - P. 72-79.

11. Kofanov A.V. The expert opinion or his analogue discussion (past and future) / Current issues of standardisation and accreditation of ballistics and weapons investigations: materials of the interdepartmental scientific-practical seminar (Kyiv, 12 January 2018) / Kyiv Scientific Research Institute of Forensic Expertise. - K., 2018. - P. 30-34. 


\title{
The Formative Stage of the Christ Apostolic Church (C.A.C) (Nigeria), 1917-1943
}

\author{
Dr. Jegede, Gabriel Gbenga \\ Faculty of Arts \\ Ekiti State University, P.M.B 5363 \\ Ado-Ekiti, Nigeria \\ E-mail: ggjegede@gmail.com
}

\begin{abstract}
The outbreak of influenza epidemic in Nigeria as from the second decade of the 20th century coupled with the worldwide economic recession within the same period forced the missionary agents of the mainline churches to abandon their mission stations. With their departure to their native countries, Christians in SouthernWestern Nigeria became stranded due to lack of spiritual leadership. This scenario forced them to form prayer groups that could assist in their spiritual needs at that critical period in their historical experience. Prominent among the prayer groups was Egbe Okuta Olowo Iyebiye (The Precious Stone Society). The group led by J.S. Sadare of Our Saviour's Anglican Church, Ijebu-Ode became the catalyst for the emergence of Pentecostalism in Nigeria, from 1917-1943. This paper traces the series of stages and events that led to the formation of the Christ Apostolic Church (C.A.C). it expounds the impact of the Faith Tabernacle Movement (Philadelphia, USA), the magazines called: Sword of The Spirit and Riches of Grace. It notes the roles of the Apostolic Church (Britain) in shaping the spiritual directions of the progenitors of the C.A.C. The paper which makes use of the descriptive historical method acknowledges the contributions of Apostle Ayo Babalola vis-à-vis the Oke-Oye revival in the events that culminated in the formation of the C.A.C. The paper concludes that the C.A.C. could be regarded as the leadinglight of Pentecostalism in Nigeria.
\end{abstract}

Key Words: Christ Apostolic Church, Nigeria, history, formative, stage.

\section{Introduction}

\section{The Beginning of The Church}

The emergence of the Christ Apostolic Church (C.A.C) on the religious landscape of Nigeria could be traced to the consequences of the nation-wide outbreak of epidemic in the second decade of the 20th century ${ }^{1}$. Consequent upon the outbreak of the influenza pandemic in about 1918, many of the churches, schools and several public institutions were closed. The missionary agents decided to leave Nigeria in large numbers. The Christians in Nigeria were therefore abandoned without the needed spiritual attention. Given the scenario, the work of evangelism was left in the hands of few African Church leaders who were compelled by the 
unforeseen situation to empathize with their brethren. Isichei sheds more light on the prevailing situation at that time:

... afflicted by epidemic (influenza, small pox and plague), famine and world economic depression; scores of people collapse on the roads, many chose shady trees under which to lie down and die. I visited some houses where every member was lying dead ${ }^{2}$.

Besides, Peel a Sociologist of Religion who carried out extensive research in South Western Nigeria, explains the prevailing mood at that time in the following words:

The Yoruba were afflicted with series of natural disasters influenza, plagues, famines and depression following the rapid growth of a monetary economy- these demanded religious interpretations. Theirs usually severe nature meant that the traditional religion, already fast declining, was inadequate to explain or relieve them, and Christianity (which has every sign of the permanence and was generally associated with what the young and ambitious felt desirable) was so used. The God whom the Christians preached had sent the disasters as a punishment but the Christian religion provided a way out ${ }^{3}$.

The epidemic which was called lùkúlùkút in Ekitiland killed thousands of people and rendered many people physically incapacitated. A foremost Catholic Priest and Chronicler of Ekiti history, Oguntuyi, paints a horrible picture of the epidemic thus:

...in October, 1918, an epidemic influenza broke out in Ekiti. Unfortunately, the cause was attributed to witchcraft and the anger of the gods. Many domestic animals were slaughtered to satisfy the blood-thirsty witches and wizards. All over Ekiti, the remedies believed by the people to be always efficacious were applied..., but the situation grew worse... The epidemic raged fiercely for about six months and thinner down the population. The dead were not mourned. Many were not even buried ${ }^{5}$.

A notable Nigerian church leader who rose to the challenge of the devastating crisis was $\mathrm{Mr}$. J.S. Sadare of Our Saviour's Anglican Church, Ijebu-Ode. In fact, in c. 1918, during his sojourn in Ibadan as a staff of the Railway Corporation, he came in contact with a praying group which was called "Egbe Okuta Olowo Iyebiye” (i.e. The Precious Stone or Diamond Society) 6 . He was very close to the prayer group during the period of the epidemic. 


\section{The Spiritual Revival at Ijebu-Ode}

On his return to Ijebu-Ode, he went into fellowship with another group of adherents of the Anglican Church in the town who had organized a revival service that was meant to enhance their spiritual fortification against the influenza epidemic. Initially, the group enjoyed the support of the top echelons of the Ijebu-Ode Anglican Church who were elated and impressed by the high level of spirituality among its members at that critical and trying period. It is worthy of note that in the prayer group at Our Saviour's Anglican Church, Ijebu-Ode, there was a school teacher, Miss Sophia Odunlami, who later got married to Mr. J.L. Ajayi. She was said to be spiritually potent and thus became a wonderful instrument for spiritual healings and deliverance. In her highly fruitful and rewarding prophecy, she revealed that "only rain-water mixed with lime could effectively cure the epidemic"?

There was an upsurge in the membership of the prayer group as Odunlami's prescription became very potent and effective in combating the epidemic scourge. Given this realization, Our Saviour's Anglican Church, Ijebu-Ode was practically turned to a healing centre for those afflicted with the influenza scurge from the entire Yorubaland and its neighbours ${ }^{8}$. This development led to a phenomenal growth and development of Christianity in South-Western Nigeria as Oshun reveals:

This was an opportunity to give vent to the group's faith in healing and in prevailing prayer. This was a new dimension to Christianity. The outcome for the group was a sharp increase in its membership as well as its growing popularity. ---The membership was seemingly drawn from among the down-trodden or the outcasts. The type of faithreaction registered at Ijebu-Ode, in confronting the menace of the pandemic was similar to the faith-reaction of the Faith Tabernacle groups in Philadelphia (US) and Accra (Ghana) ${ }^{9}$.

The first reaction of the Anglican Church to the spiritual proclivities of the Diamond Society was favourable and encouraging. It (the Anglican Church) supported the timely spiritual revival because it encouraged many people to become Christians. It also resulted in meaningful membership boost for the Anglican Church at Ijebu-Ode.

However, the initial romance and honeymoon soon turned sour. The spiritual revival championed by Sophia Odunlami was soon viewed as being diametrically opposed to the 
orthodox doctrinal practices of the $\operatorname{church}^{10}$. Even Sophia herself was considered to be probably acting under the spiritual ecstasy and perversive influence of some demonic forces. Fatokun reveals further the impact of the spiritual proclivities of Odunlami vis-à-vis the Precious Stone Society:

Shadare was forced to resign his seat at the synod. Similarly all teachers who were members of the society were asked either to renounce their membership with the "fanatical group" or else lose their jobs and also withdraw their children from the Anglican Schools. The leadership and members of the Precious Stone Society felt unjustly victimized and persecuted, and so they left the Anglican Church, and started holding meetings as a district church-- In 1923, all branches of Precious Stone Society unanimously agreed to affiliate with the Faith Tabernacle Congregation, a holiness movement with headquarters at Philadelphia, U.S.A ${ }^{11}$.

The affiliation with the foreign faith group was facilitated through the efforts or assistance of David Odubanjo $^{12}$ who heads its Lagos branch. In spite of the negative dispositions of some people towards the "Diamond Society", it continued to blossom.

\section{Affiliation with The Faith Tabernacle Movement}

What served as a turning point in respect of the spiritual awakening championed by members of the Diamond society at Ijebu-Ode was the influence of a magazine called Sword of The Spirit. It was published by "The Faith Tabernacle" which was based in Philadelphia (U.S.A) ${ }^{13}$. The Faith Tabernacle made it a duty to distribute free copies of its magazine (Sword of the Spirit) to its numerous subscribers in Nigeria ${ }^{14}$.

Given the similarities in the belief of the Faith Tabernacle and that of the Diamond Society in respect of healings through prayer, baptism of the holy spirit and adult baptism as against infant baptism, there began a form of collaboration between the two groups ${ }^{15}$. The shared beliefs of both the Diamond Society and The Faith Tabernacle were not compatible with that of the Anglican Church, hence members of the Diamond Society could not stay there and still remain relevant. To aggravate the incompatibility of the Diamond Society and the Anglican Church, Mr. S. Sadare refused to abide by the decision of the Anglican Synod of Ijebu-Ode in 1920 to release his children for early or infant baptism ${ }^{16}$. He was rigid and unwavering in hi 
stance that he had been warned against a compromise with such practice by the Holy Spirit in his spiritual encounters and experiences.

Consequent upon the reluctant of members of the Diamond Society to abandon its position in favour of the views of the Anglican Church on healings and baptism, Sadare and other members of his prayer group were excommunicated from the Anglican Church. Also, with its belligerent posture, the Diamond or Precious Stone Society left the church and affiliated officially with the Faith Tabernacle Movement in Philadelphia (USA).

By 1922, the FTM was already institutionalized in Nigeria with branches in Lagos, Kaduna, Kano, Ilesa, Zaria, Jos, Minna Ijebu-Ode ${ }^{17}$, etc. The movement was further strengthened when many of its leaders in Nigeria were ordained by proxy from $1923-1925^{18}$. Beneficiaries of the ordination were: J.S. Sadare (Ijebu-Ode), J.A. Babatope (Ilesa), S.A. Mensah (Kaduna), G.L. Macaulay (Zaria), G.S. Ogunji (Jos), Pastor Epelle (Umuahia) and to crown it all Pastor Odubanjo (Lagos) was appointed as the General Overseer ${ }^{19}$ (G.O) of the F.T.M. in the country.

As a prolific writer, Pastor Odubanjo contributed greatly to the success of the FTM in Nigeria through his monthly circular letters. Such correspondence cemented the bound of unity within the ranks and files of the movement. Essential information concerning members and leaders got easily circulated to all the nooks and crannies of the country through the instrumentality of the FTM News cum Odubanjo's letters.

1926 marked a turning point in the relationship between FTM (Philadelphia) and its Nigerian affiliate as the Principal was bedeviled by a serious crisis in which Pastor Clarke was a notable actor ${ }^{20}$. Also, involved in the misunderstanding were the other top echelons of FTM in Philadelphia. So bad were the irreconciliable differences of the belligerent groups or parties that Pastor Clarke decided to part ways with FTM and opted to establish his own separate church.

While the confusion and crisis were going on, Odubanjo inadvertently came in contact, in the course of his numerous correspondence, with a different Christian religions group called "Faith and Truth Temple" (FTT) which had its headquarters at Toronto in Canada ${ }^{21}$. As a coincidence, at the time of his discovery, the authority of FTT had concluded plans to send some missionary agents to Upper Volta. He cashed in on the opportunity by requesting them to pass through Nigeria, on a visit, before going to their main destination. 
As requested by Pastor Odubanjo, the agents of F.T.T led by Rev. C.R. Myers paid a visit to members of the Lagos branch of F.T.M. Unfortunately, their adventure was met with fatal consequences as two of the missionary agents died in Lagos of malaria fever. Besides, Myers came back to Lagos from Upper Volta in abject poverty. To add to his frustrations, he lost both his wife and his child and there also developed a frosty relationship between him and his principals at the headquarters of the F.T.T in Canada.

\title{
The Oke-Oye Revival of 1930
}

The FTM came into prominence in 1930 given the epoch-making events that inadvertently resulted from its delegate conference held at Ilesa in the year under reference. The historic revival after the conference came into being as a result of the spontaneous response to the miraculous feat of Prophet Ayo Babalola who was a delegate at the conference ${ }^{22}$. He stunned participants at the event and people in the host community when he miraculously raised to life a dead man that was being carried to a cemetery for burial. Prof. Oshun gives an eloquent testimony to this:

\begin{abstract}
Babalola had accosted some people on a funeral procession and had requested that the corpse be lowered down. After this, he prayed on the corpse shouting the name of Jesus thrice and ringing his bell at the same time. On the third occasion and to the amazement of all present, the dead man, later recognized as Mr. Obi Ogundipe was revived. Instantly, there was spontaneous jubilation and excitement all over the place which drew the attention of the leaders inside the church to the development outside ${ }^{23}$.
\end{abstract}

The miraculous feat brought the delegate conference to a sudden closure. Instead the growing crowd of enthusiastic Christians started a revival inadvertently. Within a very short time (even with the poor system of communication at that time), the news of the revival at Ilesa spread to all the nooks and crannies of Ondo, Ekiti, Igbomina, Oyo, Ogun and Benin, among others. According to Ayegboyin \& Ishola, "the heavy throng of people cleared the bushy crusade ground with their bare feet" 24 . The unprecedented responses were far beyond the imagination of members of the F.T.M.

Given the fact that the number worshippers at the revival increased daily in geometric progression, river Oye which was very close to the revival ground was consecrated and 
symbolically used to solve various ailments and spiritual problems. In fact, it was reported that an avalanche of patients in the hospital discharged themselves or were discharged by their family members ${ }^{25}$ against the instance of the hospitals managements, and carried to the venue of the revival for miraculous healings. The mass movement of patients from the government hospital infuriated the District Officer who accused Apostle Ayo Babalola and his followers of sabotage.

Shortly after the Oke-Oye revival, Babalola also incurred the wrath the colonial administration for "forcefully making people accused of witchcraft to confess" 26 . In addition, members of the FTM were accused of incitements against the colonial government ${ }^{27}$. The specific accusation had to do with the group's preachings against the use of medicine and preference for absolute faith healing. There was also a strong insistence by the government that the Oye river being used for healing purposes was highly unhygienic and could trigger serious health crisis in the whole of South-Western Nigeria.

In furtherance of the belligerent postures of the colonial administration, some leaders of the F.T.M, including Babalola were detained severally. They were equally arraigned before the court on spurious allegations ${ }^{28}$. To clip the wings of the F.T.M and to water down their reputation, the colonial Administration issue stern warnings against the consecration of water for healings and the practice of keeping residents awake by vigils and open-air services. The climax of the strained relationship between the government and members of the F.T.M was the arrest of Babalola at Otuo in the first quarter of 1932 and his imprisonment in Benin for about six months.

\section{Panacea to Hostilities and Second Affiliation}

Given the open display of hostilities by the colonial governments. In order to abate the spate of the attendant persecutions by the agencies of government, leaders of the F.T.M deemed it expedient to seek for foreign supports through affiliation with a British Church that could get the listening ears of the top echelon of the government. To achieve this, Pastor D.O. Odubanjo of the Lagos Assembly of the Faith Tabernacle who had been in regular contact with the Apostolic Church in Bradford, Britain, introduced the official magazine of the Apostolic Church, Riches of Grace to the F.T.M members. After a through analysis and deep study of 
magazine, members were convinced that the Apostolic Church have doctrines and beliefs that were compatible with those of the F.T.M.

As a corollary to the above, and following an appeal by members of the Faith Tabernacle in Nigeria, the Apostolic Church in Bradford sent three missionary agents: D.P Williams, A. Tumbull and W.J. Williams to make very formal its affiliation with the F.T.M ${ }^{29}$. After a deep and broad discussion, a memorandum of agreement cum understanding was signed with the British Apostolic Church (B.A.C). Consequently, the Faith Tabernacle members henceforth adopted the name "Apostolic Church".

In 1932, BAC sent two missionary agents to Nigeria on permanent basis. Their first task was to normalize the strained relationship between members of Faith Tabernacle and the colonial administration ${ }^{30}$. After the truce initiated by the resident pastors from Britain, the colonial government changed its hitherto hostile posture towards members of the Faith Tabernacle and became friendly. The new development facilitated or led to the release of Apostle Joseph Ayo Babalola from prison.

\section{Disagreement Between British Apostolic Church (BAC) and Apostolic Church Nigeria $(\mathrm{ACN})$}

The honeymoon between the B.A.C and A.C.N was shortlived. Few years after the affiliation, the duo disagreed sharply over the insistence of the white British missionaries on the use of medicine, notably quinine ${ }^{31}$. The B.A.C. agents held tenaciously to their position that there was nothing wrong in taking curative and preventive drugs so as to protect themselves from the fatal malaria parasites.

The top echelon of the A.C.N such as Pastors Akinyele, Esinsinade, Odubanjo and Babalola, among others were terribly frustrated by the rigid stance of B.A.C missionaries under the leadership of George Perfect ${ }^{32}$. Nevertheless, some members of the F.T.M in A.C.N decided to stick to their own position on the sanctity of divine healing. Specifically, in 1939, there was a schism which arose from the controversy. The aftermath effect was that those who were vehemently opposed to the use of drugs left the fold and began their own separate church under

the nomenclature: Nigerian Apostolic Church (N.A.C) ${ }^{33}$. Others who pitched their tents with the British missionary agents decided to use the name: The Apostolic Church (T.A.C) ${ }^{34}$. 
Given the growth and development of the N.A.C, especially when it spread its tentacles or influence beyond the shores of Nigeria, the nomenclature (N.A.C) became highly inappropriate. Later, there were pressures from members outside the country on the need to drop "Nigeria" in favour of a nomenclature that would give the church a universal appeal ${ }^{35}$. Consequently, in February 1940, the name of N.A.C was changed to United Apostolic Church (U.A.C).

However, after the adoption of the nomenclature U.A.C, members of the church came to the realization of the obvious fact that the acronym was the same as that of a trading firm in south-western Nigeria, that is: the United African Company (U.A.C). In fact, there was the strong fear or apprehension that such similarity in names would certainly confuse members of the public and government. To solve the problem, the church decided again to change its name to: Christ Apostolic Church (C.A.C) in $1941^{36}$. The new name was given a legal zeal or teeth with the official registration in $1943^{37}$. Later, the church began to share the name with another agency of government, the Corporate Affairs Commission.

\section{Conclusion}

The foregoing discussion deals with the formative stage of the Christ Apostolic Church (C.A.C) in Nigeria. The institutionalisation of the church in some other parts of Yorubaland could be attributed partly to the efforts of Apostle Ayo Babalola and Pastor J.A. Babatope, given their exploits shortly after the Oke-Oye revival at Ilesa in 1930.

In fact the intimidating presence of the mainline churches in Nigeria before the emergence of the C.A.C did not preclude it from making the South-Western Nigeria one of its strongholds. As a result of its ubiquitous presence in all the nooks and crannies of the communities in southern Nigeria by 1943, coupled with the teeming population of adherents, the C.A.C could be regarded as the fastest growing Pentecostal Church within the scope or period under examination. Besides, its pioneering efforts with regard to the entrenchment of Pentecostalism in Nigeria is equally not in doubt.

\section{Notes and References}

1. S.G.A. Adegboyega, A Short History of The Apostolic Church, (Ibadan, Roseprint Press Limited, 1978), P. 1; E. Isichei, A History of Nigeria, (London, Longman Group Limited, 1984), P. 462. 
2. E. Isichei, A History of Christianity in Africa from Antiquity to the Present (New Jersey, William .B. Eerdmans Publishing Company, 1995), P. 280; R.C. Mitchell," Religious Protest and Social Change: The Origins of The Aladura Movement in Western Nigeria", in R. Rotberg \& A. Mazni (eds), Protest and Power in Black Africa, (New York, Oxford University Press, 1970), P. 481.

3. J.D.Y. Peel, Aladura: A Religious Movement Among The Yoruba, (London, Oxford University Press, 1968), P. 292.

4. The nomenclature "lukuluku" (an onomatopoeic) was given to the influenza epidemic of the second and third decades of the 20th century in most towns in Ekitiland due to its attendant killing en-masse and by sudden strokes.

5. A. Oguntuyi, History of Ekiti from The Beginning to 1939, (Ibadan, Bisi Books Company Limited, 1979), P. 123.

6. T. Adamolekun, "Christianity in African Context", in S.I. Ogunsakin - Fabarebo and O. Arowolo (eds.), Foundation Themes in Religion, (Akure, Don Boscos Press Limited, 2001), P. 132.

7. P.A. Adebiyi, History of Christianity in Ekitiland, 1893-1973, (Lagos, C.S.S. Limited, 2003), P. 131.

8. $\quad$ S.G.A. Adegboyega, A Short History... P. 7.

9. C.O. Oshun, "Origins of Christ Apostolic Church, Nigeria: A Critical Assessment of An African Aladadura-Apostolic-Pentecostal Church, 1918-1959”. Being the text of a paper presented to an International Religious Conference on the origins of Christ Apostolic Church. The First Pentecostal Churches in Nigeria and Ghana Jointly organized by The Centre for World Christianity (CWC) of the New York Theological Seminary (NYTS), Joseph Ayo Babalola University (JABU), Ikeji-Arakeji, Osun State, Nigeria, and The Institute for Disaporan and African Culture (TIDAC), Joseph Ayo Babalola University, 6th - 8th August; 2012, P. 5.

10. S.G.A. Adegboyega, A Short History... P. 8.

11. S.A. Fatokun, "The Apostolic Church Nigeria: The Metamorphosis' of Indigenous Prophetic - Healing Movement into a Classical Pentecostal Denomination”, in S.A. Fatokun (ed.) Christianity and African Society, (Ibadan, Bookwright Publishers (Nigeria) 2013), P. 75.

12. S.J. Komolafe, The Transformation of African Christianity, (Carlisle, Longham Monographs, 2013), P. 103.

13. J.D.Y. Peel, Aladura: A Religious Movement Among the Yoruba, (New York, O.U.P, 1968), P. 61.

14. D. Ayegboyin \& S.A. Ishola, African Indigenous Churches: An Historical Perspective. (Lagos, Greater Heights Publications Limited, 1999), P. 66.

15. E.H.L. Olusheye, A Short History of The Christ Apostolic Church, (Ibadan, IBI Press and Publishing Company, 2000), P. 30. 
16. H.W. Turner, History of The African Independent Church, (London, Oxford University Press, 1967), pp. 4-5.

17. D. Ayegboyin \& S.A. Ishola, P. 67.

18. P.A. Adebiyi, P. 133.

19. Brochure of The Apostolic Church, Ilesa on Late Pastor J.A. Babatope, 1st African Superintendent - The Hero of Faith, (Ilesa, Haastrup Press, 1993), P. 3.

20. E.A. Ademowo, "The Growth of The Apostolic Church in Ijesaland, 1930-1990". An M.A. thesis submitted to the Department of Religious Studies, Obafemi Awolowo University, Ile-Ife, Nigeria, 1997, P. 63.

21. Ibid. P. 64.

22. C. Ekundayo, Itan Igbesi ati Ise Iranse Josefu Ayo Babalola, 1904-1959, (Ibadan, United Christian Publications, 2004), pp. 16-20.

23. C.D. Oshun, "Origin of Christ... P. 13.

24. D. Ayegboyin \& S.A. Ishola, P. 74.

25. E.H.L. Olusheye, P. 17.

26. S.G.A. Adegboyega, P. 30.

27. D. Ayegboyin \& S.A. Ishola, P. 75.

28. Ibid. P. 75 .

29. Ibid. P. 76.

30. S.I. Ogunsakin - Fabarebo \& O. Arowolo (eds.), Foundation Themes in Religion, (Ondo, Don Bosco Publishing Company, 2001), P. 134.

31. B.P. Clarke, West Africa and Christianity, (London, Arnold Press, 1986), PP. 167-169.

32. D. Ayegboyin \& S.A. Ishola, P. 77.

33. Ibid. P. 77.

34. Ibid. P. 77.

35. C.O. Oshun, "The Pentecostal Perspective of the Christ Apostolic Church", in ORITA: Ibadan Journal of Religious Studies, Vol. 15, No. 2, (December, 1983), pp. 105-114.

36. S.B. Mala, "The Christ Apostolic Church: Its History, Beliefs and Organization", Faith Order Paper no. 79. The Ecumenical Review, Vol. 28, No 4 (October, 1976), pp. 418428.

37. J.A. Alokan, Idasile Ijo Apostolic ni Efon-Alaaye Ekiti, (Ibadan, Caxton Press, 1975), pp. 18-21; I.O. Eyebiokin, Igbedide Aposteli Joseph Ayo Babalola Pelu Ibere ati Idagbasoke Ijo C.A.C ni Ilu Ado-Ekiti, (Ado-Ekiti, Greenline Publishers Limited, 2004), P. 20ff. 


\title{
The Driving Power of Social Processes from the Perspective of History of Science and Technology
}

\author{
Leonid Griffen \\ ORCID: https://orcid.org/0000-0002-3020-9636 \\ Doctor of Technical Sciences, Professor, Scientific Secretary of the National \\ Historical and Architectural Museum "Kyiv Fortress" (Kyiv, Ukraine) \\ e-mail: lagrif@mail.ru \\ Nadiia Ryzheva \\ ORCID: https://orcid.org/0000-0001-8379-4325 \\ Doctor of History, Professor, Head of the History Department at \\ V.O.Sukhomlynskyi National University of Mykolaiv (Mykolaiv, Ukraine) \\ e-mail: ryzheva.nadiya@gmail.com
}

\begin{abstract}
The Article attempts to consider social processes occurring at the present stage of human development in accordance with such a scientific discipline as the History of Science and Technology. The development of productive forces which, in fact, is a complex result of the progress of scientific knowledge and technology, leads to the formation of such a social phenomenon as the division of labor (and first of all, the division of «physical» and «mental» labor) which mainly affects the nature of other social processes, from the total division of humanity in a slave-owing society to the global division of labor between Western nations and all other countries. At each stage of global change in human life, increasing productivity and social progress was accompanied by the need to solve a wide range of new problems. However, in the process of development of modern society (dominant «capital»), its very progress as well as the state of productive forces leads to a crisis in the international division of labor, which in turn leads to a crisis of the social system as a whole.
\end{abstract}

Key words: History of Science and Technology, productive power, division of labor, the crisis of the international division of labor.

Надзвичайно складними проблемами сьогодні відзначені соціальні процеси в усьому світі, де тривають стрімкі зміни суспільної ситуації. Оскільки ці процеси мають об'єктивний характер, можна стверджувати, що найближчими роками світ зміниться кардинальним чином. Зміни ці передусім викликані бурхливим розвитком продуктивних сил суспільства. I чим швидше ми зрозуміємо спрямування й характер їх подальшого розвитку, тим легше буде пристосуватись до неминучих суспільних змін, i тим меншу ціну заплатить за них людство. 
Зрозуміти й, відповідно, передбачити тенденції будь-яких процесів можна, лише виконавши на основі дослідження їх попередньої історії наукову екстраполяцію тривання цих процесів на майбутнє. У цьому випадку особливу роль покликана зіграти галузь історії науки і техніки [1]. Адже продуктивні сили - це, власне, й є наука і техніка в їхній сукупній соціальній функції. 3 функційної ж точки зору продуктивні сили покликані здійснювати взаємодію суспільства як системи, що саморозвивається, 3 навколишнім середовищем. Це інструмент забезпечення людства засобами існування, а тому його розвиток, в якому зацікавлене і суспільство як система, і кожен іiі елемент чи підсистема - індивід або їх група, - розвивається постійно і спонтанно. Хоча це не означає, що вказаний розвиток не підлягає закономірностям. Ці ж закономірності, у свою чергу, визначаються обсягом і систематизацією накопичених знань, з одного боку, та рівнем і характером розвитку сукупності технічних пристроїв - 3 іншого.

Уже первісна людина, 3 метою виживання, намагалась орієнтуватись в навколишньому світі, що забезпечував іiі існування, хоча і приховував масу небезпек. Поступово людина як соціальна істота накопичувала знання про конкретні об’єкти і намагалася звести їх у більш-менш струнку систему. Спочатку з такою метою люди, так би мовити, «накладали» відомі зв’язки середовища на оточуючий світ (зооморфізм, антропоморфізм), тобто зводили суму знань у міфологічну систему. Така система у різних своїх формах, не зважаючи на фантастичність, служила людям протягом тисяч років.

Що ж до техніки, яку суспільство розташовувало між собою й навколишнім середовищем, то саме вона безпосередньо визначала ефективність взаємодії між ними. Будучи породженням суспільства, технічні пристрої, однак, приводились у дію конкретними індивідами, які знали механізми їх створення і використання. За словами Х. Ортега-і-Гассета, «простота і мізерність первісної техніки призводять до того, що пов'язані з нею дії можуть виконуватись усіма членами спільноти, тобто всі розпалюють вогонь, майструють луки, стріли тощо. Техніка не виділяється зі всіляких занять» [2].

Поступово технічні пристрої ускладнюються, стають чисельнішими i різноманітнішими, а технологія їх виготовлення і застосування -складнішою. Істотно зростає також обсяг знань, потрібних для виконання тих чи інших операцій. 
3 іншого боку, вказані обставини, а також зростання чисельності первісного колективу, потребували все більше кооперативних зусиль, що, своєю чергою, вимагало їх координації як особливого виду діяльності.

Відповідно, конкретні реалії життєдіяльності призводили до певної спеціалізації, що супроводжувалася підвищенням продуктивності праці і породжувала таке специфічне соціальне явище, як суспільний розподіл праці. Поперше, це спонукало до технологічного розподілу, коли різні працівники спеціалізуються в різних галузях виробництва. По-друге, вирізняється соціальний розподіл, коли від тих, хто безпосередньо впливає на предмет праці, відділяються ті, які роблять це не безпосередньо, а опосередковано, через перших (розподіл «розумової» і «фізичної» праці). Отже, кожен вид суспільного розподілу праці, крім підвищення іï продуктивності, впливає також на інші суспільні процеси, але саме розподіл «розумової» та «фізичної» праці має істотний вплив на характер розвитку суспільства (яке з цього часу набуває характеру суспільства класового) і на його форму відповідно до форми розподілу праці.

Відомо, що поява перших держав грунтувалася на поділі суспільства на рабів вони виконували технологічні операції - та рабовласників, які забезпечували їх організацію та технологічний рівень суспільства. Здійснювалося це також через тотальну власність останніх на засоби виробництва (до яких відносилися й раби). Зростання продуктивності праці досягалося, перш за все, організаційними заходами щодо робочої сили. Представники панівного класу мали можливість розвивати науку і техніку, що теж було їх важливою перевагою. Головним недоліком організації такого суспільства, який, зрештою, привів до падіння цього способу виробництва, стала повна незацікавленість безпосередніх виробників в ефективності праці.

У подальшому розвитку цивілізації відбувалася поява нового панівного класу феодалів, які володіли головним засобом виробництва - землею. Проте іншими засобами виробництва (достатньо примітивними), що безпосередньо використовувалися у виробничих процесах, володіли самі виробники. Нові реалії суттєво підвищили зацікавленість останніх як у вдосконаленні засобів виробництва, так і в їхньому ефективному використанні. Крім того, відбувалася диференціація серед 
виробників із виділенням кустарних промислів (що призвела до появи суспільної верстви ремісників).

Набуває нових алгоритмів і пізнавальна діяльність, що на цей час інтенсивно розвивалася в формі філософії, котра передбачала формування певних умоглядних систем зі спробами їх накладання на реальні процеси (характерний приклад - система Птоломея). Формуються також засади наукових знань, хоча й на основі того ж «філософського» підходу (наприклад, алхімія). Усе це веде до поступового зростання продуктивних сил.

Незважаючи на повільні темпи розвитку, феодалізм виявився достатньо сталою соціальною системою. Якщо рабовласницькі держави мали характер певного «вкраплення» в морі родоплемінних утворень, то феодальні, у складі різних цивілізацій, заповнили майже весь простір тодішньої Ойкумени. Вони намагались потіснити одна одну, але вело це лише до часткових результатів. I так тривало до початку доби Великих географічних відкриттів, коли ситуація докорінно змінилася.

Головну роль тут у зв'язку з рядом причин відіграла західноєвропейська цивілізація. Зіткнувшись із народами, що стояли на нижчому рівні соціальнокультурного розвитку, західноєвропейці скористалися цим уповні. Так розпочався розвиток принципово нової формації, у якій головним видом розподілу праці став глобальний, міжнародний - між панівним Заходом та іншим світом. За рахунок грабунку інших цивілізацій відбувався потужний поштовх розвитку продуктивних сил метрополії - країн Західної Європи. Зокрема, наявність економічного потенціалу колоній зробила можливою так звану «промислову революцію», що розпочалася в Свропі в кінці XVIII ст. «Революція ця була... знаряддям панування і знищення міжнародної конкуренції. ... Картина світової історії з 1400 або 1450 р. по 18501950 pp. - це картина старовинної рівності, яка руйнувалася під впливом багатовікового спотворення, що розпочалося 3 кінця XV ст. Порівняно 3 цією домінантною лінією все інше було другорядним» [3]. Промислова революція закріпила панівне положення Заходу в міжнародному розподілі праці, а потім наукова революція, що іï забезпечувала, додатково надала поштовх розвитку науки як третьої форми пізнавальної діяльності. 
Інші ж країни-колонії, експлуатовані Заходом, значно відставали в соціальноекономічному розвитку. Однак із часом і в них, за рахунок проникнення технічних $\mathrm{i}$ наукових досягнень метрополії, відбувався певний науково-технічний прогрес, що змушувало країни метрополії віднаходити нові можливості експлуатації робочої сили колоній. Особливо важливим для них це стало після Другої світової війни внаслідок краху колоніальної системи. І сьогодні одним із найважливіших механізмів отримання прибутку капіталістами Заходу за рахунок експлуатації «третього світу» став вивіз капіталу, коли виробництво переноситься в країни з низькою вартістю робочої сили.

Однак унаслідок цього одночасно проходить і розвиток виробництва в країнах, що «розвиваються», і деіндустріалізація «цивілізованих» країн. Іншими словами, в колишніх колоніях відбувається прискорений розвиток продуктивних сил. Туди переводяться сучасні технології, спрямовуються і готуються на місці інженерні та наукові кадри, зростає кількість кваліфікованих робітників. Одночасно в «цивілізованих» країнах промислова економіка перетворюється на «сервісну», втрачається промисловий потенціал і падає кваліфікація робочої сили. У результаті темпи розвитку «периферії» капіталістичної системи прискорюються, а темпи розвитку іiї «ядра» знижуються (наприклад, у найбільших «країнах, що розвиваються», ці темпи в середньому складають 7,5\% валового внутрішнього продукту на рік, а в західних - усього 2,5 \%). При чому на «периферії» швидко розвивається так званий «середній клас» і підвищується його добробут, а в «ядрі» цей самий «середній клас» убожіє й знижується його суспільна роль [4].

У наш час Китай обігнав США не лише за обсягом ВВП, але й за кількістю патентів. Інакше кажучи, реалізація капіталізмом власних законів функціювання веде до втрати його переваг щодо розвитку продуктивних сил, і це відповідно ставить питання про його подальше існування.

Сьогодні Захід намагається зберегти наявний статус не за рахунок розвитку виробничих сил і вигідного йому розподілу праці, а завдяки подальшому фінансовому і військовому пануванню. Однак без опори на базис ця перевага не може залишатись тривалою, тому фундамент у вигляді вигідного Заходу міжнародного розподілу «розумової» і «ручної» праці руйнується. Цьому сприяє розвиток продуктивних сил, завдяки якому пришвидшений науково-технічний прогрес, а з ним - і перерозподіл 
соціальної «ваги» «розумової» та «фізичної» праці, що об’єктивно знижує питому вагу останньої.

Отже, у процесі розвитку сучасного суспільства (панівного «капіталу») стан продуктивних сил призводить до кризи соціальної системи. Загалом руйнується притаманна капіталізму «вертикальна» побудова світової системи у вигляді своєрідного «айсберга» 3 надводною частиною - «цивілізованих» країн Заходу, і підводною, що забезпечує пливучість усієї міжнародної соціальної конструкції, - всіх інших. Можливо, найближчим часом остання буде поступово перетворюватися на сукупність регіональних соціальних утворень 3 іншим соціально-економічним укладом, що характеризуватиметься іншим рівнем продуктивних сил та іншим характером розподілу праці.

\section{References}

1. Бєсов Л.М. Історія науки і техніки. 3-є вид., переробл. і доп. Харків: НТУ "ХПІ", 2004. 382 c.

2. Ортега-и-Гассет X. Размышления о технике // Вопросы философии. 1993. № 10.

3. Бродель Ф. Время мира. Москва: Изд-во Прогресс, 1992. 551 с.

4. Макдональд Л. Реальные причины победы Трампа // http://colonelcassad. livejournal.com/ 25 декабря 2016 г.

\section{Translation of the Title and Abstract to the Author's Language}

\section{Гриффен Л., РЫжева Н. РУШІЙНА СИЛА СОЦІАЛЬНИХ ПРОЦЕСІВ ІЗ ТОЧКИ ЗОРУ ІСТОРІЇ НАУКИ І ТЕХНІКИ}

У статті зроблено спробу розглянути соціальні процеси сучасного етапу розвитку людства відповідно до галузі історії науки і техніки. Розвиток продуктивних сил, які, власне, й є комплексним результатом прогресу наукових знань і технології, приводить до становлення такого соціального явища, як розподіл праці (і перш за все, розподіл «фізичної» та «розумової» праці), що найістотнішим чином позначається на характері інших соціальних процесів, від тотального розподілу людства в рабовласницькому суспільстві до глобального розділення праці між колективним Заходом та іншими країнами. На кожному етапі глобальних змін життєдіяльності людства підвищення продуктивності праці i зростання суспільного прогресу супроводжувалися потребою вирішення широкого кола нових проблем. Однак у процесі розвитку сучасного суспільства (панівного «капіталу») його поступ і стан продуктивних сил призводять до кризи в міжнародному розподілі праці, що веде до кризи соціальної системи загалом.

Ключові слова: історія науки і техніки, продуктивні сили, розподіл праці, криза міжнародного розподілу праці. 


\title{
Increased Customer Loyalty in the Retail Banking Sector and Impact on the Bank's Financial Performance
}

\author{
Assel Iskhakova \\ Independent researcher, Kazakhstan
}

\begin{abstract}
This article examines the key aspects of bank customer loyalty. In modern conditions of market competition, in any stable company or financial institution, one of the main goals is to attract new customers and retain existing ones. Therefore, there is a need for the bank and all companies in general to develop a plan for building stable customer satisfaction, as well as build a path with the study of analysis, with drawbacks and possible losses, in order to have a stable loyalty program. When implementing this program, it will develop a range of marketing activities. This topic can show that the loyalty program is one of the key levers for attracting customers, which will primarily affect the profitability, income and performance of the bank as a whole. Thus, it can also be noted that in the future in any developed or developing country, this program will gain new momentum in the field of business and banking services.
\end{abstract}

Keywords: Loyalty, Bank, Financial Performance, Retail Banking

В условиях быстро растущей конкуренции, роста затрат на привлечение клиентов, такие понятия как « потребительская лояльность » и « уровень обслуживания » становятся неразделимыми понятиями.

На данном этапе и возникает вопрос о лояльности персонала. Если сотрудники как минимум, влияют на процессную сторону, то отношенческая сторона обслуживания прежде всего будет зависеть от персонала. Сотрудник, который абсолютно лояльный к своему банку, не объединяется в критике работы своей организации, он всегда стремится показывать ее с лучшей стороны, более вовлечен в продукт, соответственно потребитель, чувствуя такую приверженность и искренность со стороны ее работников по отношению к данному продукту и данной компании, получает как минимум положительные эмоции и как максимум принимает быстрое решение о покупке, рекомендует компанию, менеджера своим знакомым и самое главное, становится более лояльным.

Актуальность исследования взаимосвязи между лояльностью сотрудников и потребителями в банковской сфере обусловлена несколькими причинами как с теоретической, так и с практической точки зрения. С практической точки зрения, можно привести следующие аргументы. Во-первых, кредитный рынок можно 
охарактеризовать как высококонкурентный, особенно в развитых странах. Сам кредитный рынок быстро обретает новые обороты. Во-вторых, на основе вышесказанного следует акцентировать внимание на том, что данный рынок находится на стадии быстрого развития, в связи с его насыщением. Соответственно, банки постепенно переходят от стратегии активного привлечения клиента, на стратегию удержания.

На Западе данная тема начала активно изучаться еще с конца 80 -х годов прошлого века, однако в странах СНГ (Казахстан, Кыргызстан, Узбекистан) можно найти лишь отдельные исследования, посвященные либо лояльности персонала, либо лояльности заемщиков.

В связи с этим, существенным достижением работы, претендующей на научную новизну, является анализ, систематизация теоретических и практических взглядов, эмпирических исследований зарубежных и казахстанских авторов о влиянии лояльности персонала на лояльность клиентов для кредитного рынка Казахстана в частности.

Качество обслуживания серьезно влияет на конкурентоспособность услуг и банка, а значит, и на стабильность доходов и прибыль. Мировой опыт и практика показывают, что инвестиции в совершенствование качества обслуживания клиентов рассматриваются как интенсивное развитие и влияют на стабильность роста доходов банка.

Наличие лояльности, т. е. благоприятного отношения потребителей к данной организации и ее продуктам, служит основой для получения стабильного объема продаж, что, в свою очередь, является стратегическим показателем успешности организации. Под лояльностью клиентов к банку понимается положительное отношение потребителей ко всему, что касается деятельности данной организации: оказываемым банковским услугам, персоналу, имиджу, исходящей от банка информации, рекламным обращениям, символике и т. п. 
Лояльными можно назвать тех потребителей, которые в течение длительного времени взаимодействуют с организацией и совершают при этом повторные покупки. Основой для лояльности служит позитивный опыт, который клиент приобрел в процессе пользования продуктом, услугой.

Важную роль играет также степень напряженности коммуникаций между потребителями банковских услуг и сотрудниками организации.

Поэтому определение приоритетных мер и необходимых корректирующих воздействий, а также дополнительных мероприятий в целях улучшения качества обслуживания в банке является первостепенным фактором его успешного существования на рынке. Уровень лояльности потребителей банковских услуг, степень их удовлетворенности качеством обслуживания в коммерческом банке предполагается определить с помощью маркетингового исследования.

На сегодняшний день наблюдается нечеткое разграничение терминов «потребительская лояльность» и «лояльность бренду». Они получили свое развитие в разное время и в рамках разных концепций: термин «лояльность бренду» был введен в употребление в начале 20-х годов в США и получил свое развитие в рамках концепции брэндинга, а термин «потребительская лояльность» стал активно развиваться в 80-е годы в рамках концепции маркетинга взаимоотношений.

Удовлетворенность клиента зависит от качества работы всей компании, тогда как программу лояльности следует рассматривать как одну из альтернатив маркетинговым коммуникациям. Однако, недооценивать роль программ лояльности также не следует, поэтому в современных условиях для большинства компаний программы лояльности для клиентов необходимо дополнять программами по повышению потребительской удовлетворенности.

\section{References}

1. Andreev A.G. Lojal'nyj potrebitel'. Marketing i marketingovye issledovanija, [Loyal consumer. Marketing and marketing research ] — 2003. — № 2.

2. L. S. Shajahovskaja, Lojal'nost' - kak filosofija [Loyalty as a philosophy]. 2003 
3. Ju. L. Bugorskaja, Ot stimulirovanija sbyta $-k$ povysheniju lojal'nosti potrebitelej: programmy pooshhrenija [From Sales Promotion to Customer Loyalty: Incentive Programs] // Marketingovye kommunikacii. - 2003 g. - № 3

\title{
Translation of the Title, Abstract and References to the Author's Language
}

\section{Повышение лояльности клиентов в сфере розничных банковских услуг и влияние на финансовые результаты деятельности банка}

\author{
Асель Исхакова \\ Независимый исследователь, Казахстан
}

В данной статье разбираются ключевые аспекты клиентской лояльности банка. В современных условиях рыночной конкуренции, в любой стабильной компании или финансовом институте, одной из основных целей является- привлечение новых клиентов и удержание уже имеющихся. Поэтому есть необходимость для банка и всех компаний в целом, разработать план по постройке стабильной удовлетворенности клиентов, так же выстроить путь с изучением анализа, с недостатками и возможными потерями, чтобы иметь стабильную программу лояльности. При внедрении данной программы, оно будет развивать комплекс маркетинговых мероприятий. Данная тема, может показать, что программа лояльности является одним из ключевых рычагов для привлечения клиентов, что в первую очередь повлияют на прибыльность, на доход и на показатели банка в целом. Тем самым можно так же отметить, что в будущем в любой развитой или в развивающейся стране, данная программа будет обретать новые обороты в сфере бизнеса и банковского обслуживания.

\section{Литература}

1. Андреев А.Г. Лояльный потребитель. Маркетинг и маркетинговые исследования, -2003 г. - № 2.

2. Л. С. Шаяховская, Лояльность - как философия 2003 г

3. Ю. Л. Бугорская, От стимулирования сбыта - к повышению лояльности потребителей: программы поощрения // Маркетинговые коммуникации. - 2003 г. - № 3 


\title{
Methods and Devices for Forming Rehabilitation Processes. Application of Artificial Intelligence and Artificial Neural Networks for Rehabilitation
}

\author{
Alexey Imamov
}

\begin{abstract}
In a modern society that implements and organizes various options for comprehensive and versatile development of the innovative economy, especially in areas related to smart industries and technologies, stress loads of all types that arise from the most active organizers of project development processes and generators of new technical and commercial ideas aimed at optimizing and accelerating development processes require an adequate response and unobtrusive, but extremely reliable and natural technologies and special equipment for rehabilitation. Keywords: rehabilitation, artificial intelligence, neural networks, stress

В современном обществе, реализующем и организовывающем различные варианты комплексного разностороннего развития инновационной экономики, особенно в областях связанных с умными производствами и технологиями, стрессовые нагрузки всех видов, возникающие у наиболее активных организаторов процессов развития проектов и генераторов новых технических и коммерческих идей, направленных на оптимизацию и акселерацию процессов развития, требуют адекватной реакции и ненавязчивых, но предельно надёжных и естественных технологий и специального оборудования для реабилитации. Настольные спортивные игры - один из важнейших и перспективных источников для всесторонних технологий реабилитации.

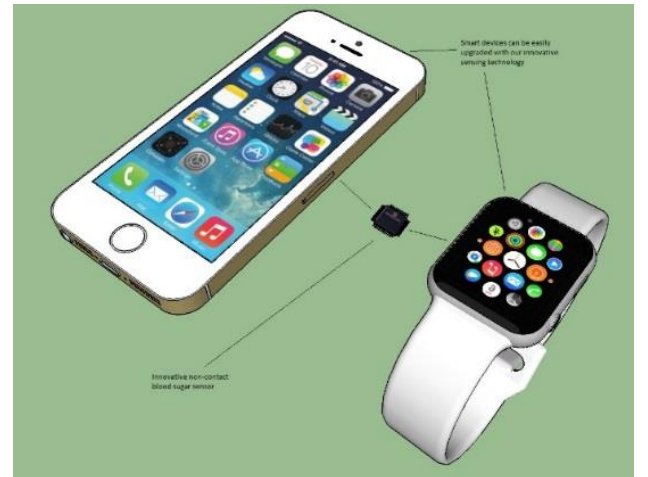

Рисунок 1, - на рисунке показана модель системных управляющих и регламентирующих комплексных модельных подсистем с использованием в качестве динамичных связей между подвижным контролируемым объектом и средствами мобильной связи бесконтактных резонансных сенсоров, работающих по принципам электромагнитной резонансной спектроскопии и имеющих различное конструктивное исполнение.
\end{abstract}

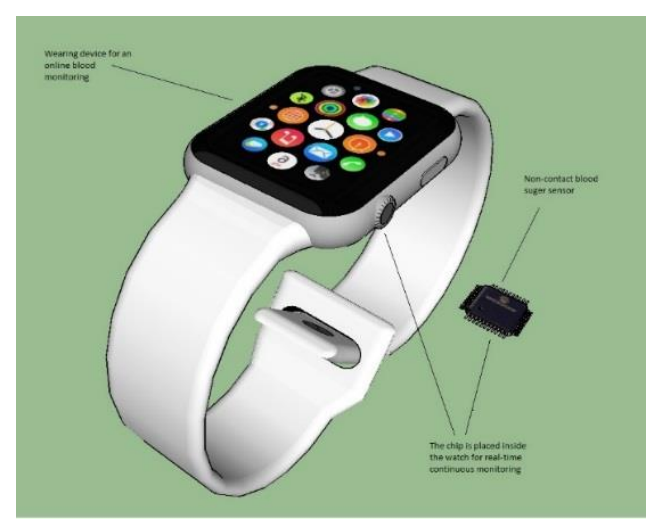

Рисунок 2 , - на рисунке также показана модель системных управляющих и регламентирующих комплексных модельных подсистем с использованием в качестве динамичных связей между подвижным контролируемым объектом и средствами мобильной связи выполненными в виде умных часов, бесконтактных резонансных сенсоров, работающих по принципам электромагнитной резонансной спектроскопии и имеющих различное конструктивное исполнение. 
Для так называемых умных часов исполнение сенсора представляет собой плоскую катушку - электронную микроплату с оригинальной топологией плоского соленоида. Такой сенсор получает энергию от батареи часов и находится постоянно в режиме контроля параметров организма игрока в настольный теннис.

При этом в мониторинге в режиме реального времени могут измеряться несколько важных параметров на которые может оказывать влияние чересчур интенсивный характер игры. Например, концентрация сахара в крови, кровяное давление и т.п.

Особую важность приобретают эти варианты применения в случае интеграции в программные системы всего реабилитационного комплекса элементов искусственного интеллекта и искусственных нейронных сетей.

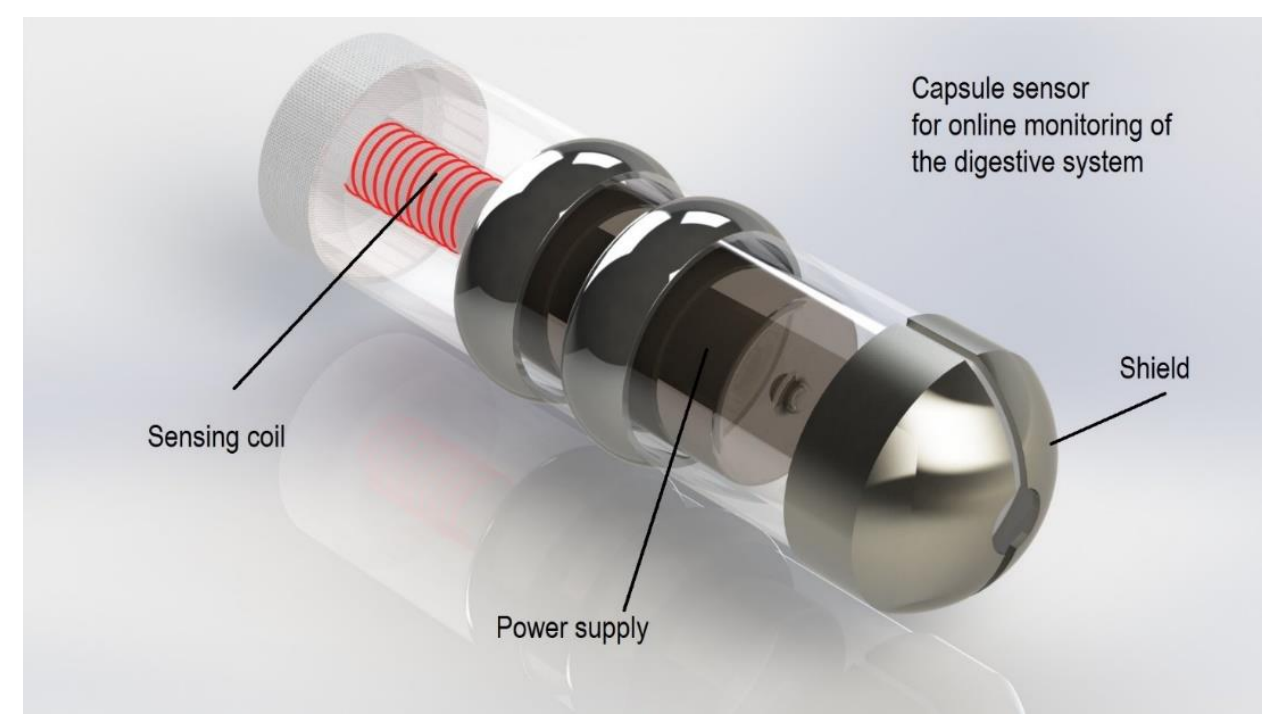

Рисунок 3, - на рисунке также показана модель интегрального сенсора, который вводится в осевое отверстие рукоятки ракетки для настольного тенниса.

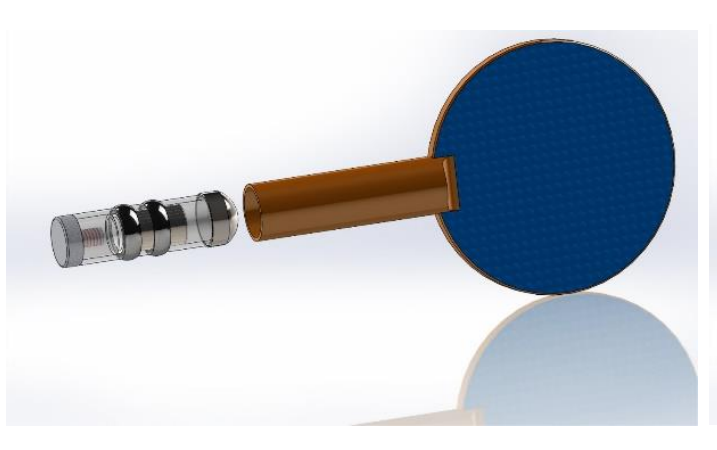

Рисунок 4

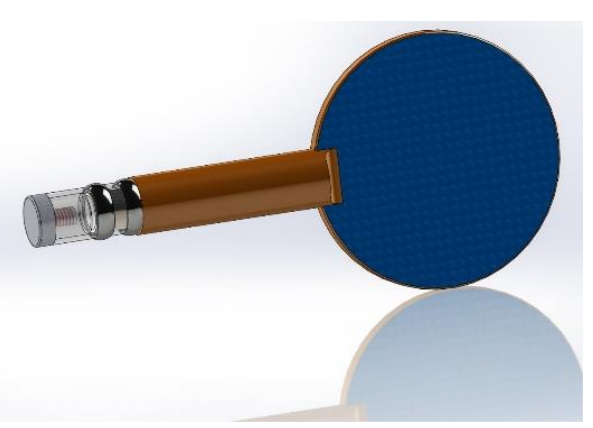

Рисунок 5 


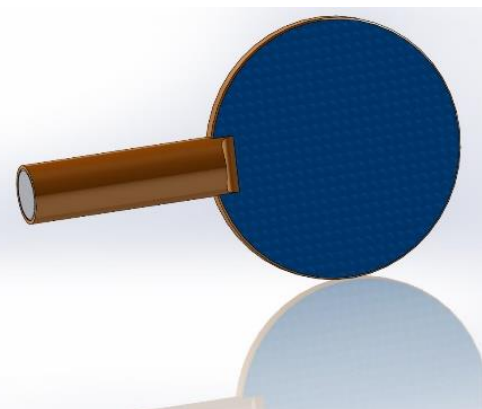

Рисунок 6

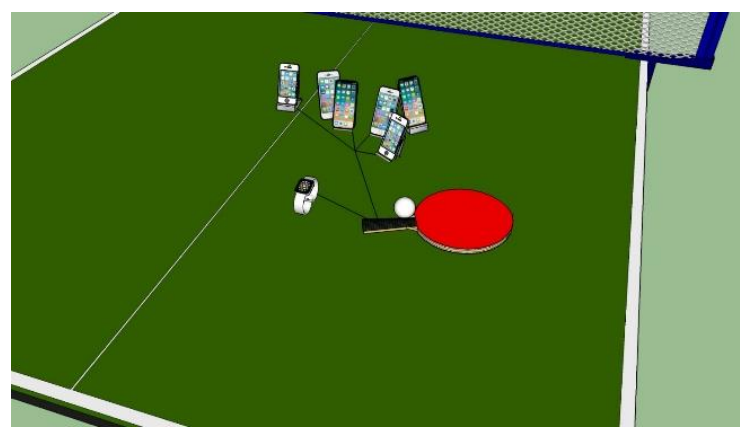

Рисунок 8

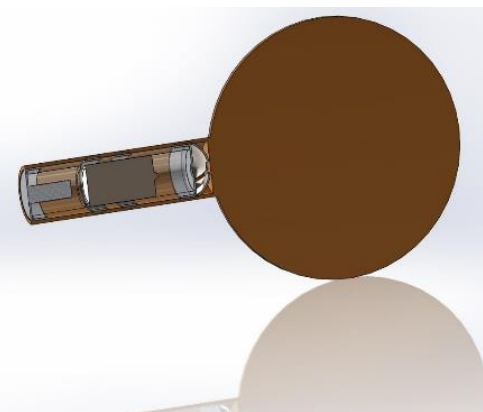

Рисунок 7

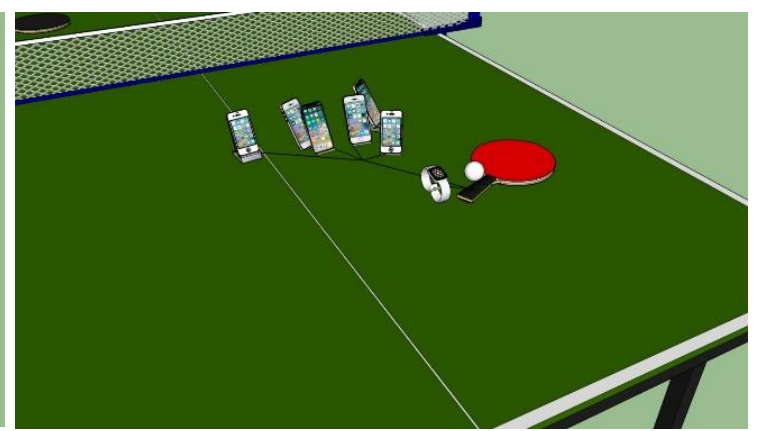

Рисунок 9

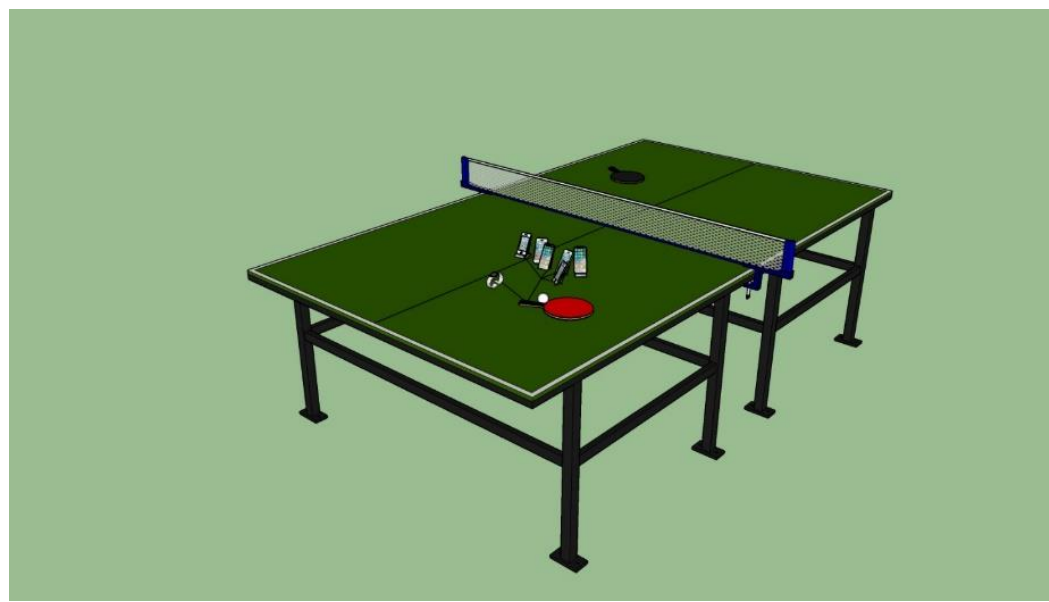

Рисунок 10

На рисунках 4-10 изображена модель.

Те, кто считают настольный теннис легким видом спорта, заблуждаются. Хотя, казалось бы, стоят два человека и перебрасывают друг другу мячик. Ну, что тут может быть сложного? Так думают лишь те, кто никогда не играл в настольный теннис. 
На самом деле «пинг-понг», развивает много не только физических, но и моральноволевых качеств. Это и сила, и ловкость, и быстрота реакции, и умение предсказывать, предвидеть ситуацию за игровым столом. При игре в теннис также развивается и мелкая моторика. Но рассмотрим все по порядку.

В таком виде спорта, как настольный теннис, сила развивается не в прямом понимании этого слова. Конечно, при занятии теннисом мышцы рук не будут такими, как у спортсменов бодибилдеров. Но мышцы, без сомнения, становятся рельефнее, так как работает плечевой сустав, бицепсы и трицепсы, а также мышцы кистей рук.

Здесь под силой подразумевается сила движения руки. Когда возникает необходимость резко атаковать соперника, застать его врасплох за столом, то удары по мячу должны быть мощными и сильными, то есть такими, чтобы соперник не сумел на них вовремя среагировать. Добавим к этому работу мышц ног, которые постоянно находятся в движении и напряжении.

Что же касается ловкости и быстроты реакции, то настольный теннис отлично развивает эти качества. Ведь при хорошей игре мяч летит очень быстро, поэтому, чтобы не потерять очки, необходимо действовать со всей ловкостью и быстротой, на которую только способен игрок.

Обычно ситуация за столом развивается мгновенно, поэтому необходимо также иметь некоторые умения предчувствовать будущее. И, буквально за долю секунды предугадать действие соперника, опередить направление полета мяча и силу удара, разгадать план действий и обмануть, а значит - обыграть.

Очень большая нагрузка в данной игре ложится на ноги игроков. Ноги выполняют большую работу по перемещению спортсмена около стола, их работа является важным фактором в игре и при достижении желанной победы. Поэтому не удивительно, что мышцы ног теннисистов очень хорошо натренированы, а это может значительно улучшить показатели и в других видах спорта, например, в беге. А значит, настольный теннис можно включить в систему тренировок некоторых спортсменов из других видов спорта.

Конечно, огромный оздоровительный эффект настольный теннис приносит сердечно- сосудистой и дыхательной системам. Ведь, перемещаясь от одного края стола к 
другому, мышцы сердца получают нагрузку, сравнимую с бегом по пересеченной местности. И чем лучше сердце натренировано, тем меньше риск сердечных заболеваний.

Дыхательная система при интенсивной игре также может получить развитие и очень полезный эффект. Происходит постоянная вентиляция легких, улучшается и тренируется их работа.

Нельзя оставить без внимания и положительный эффект от занятий на зрительную систему человека. Особенно, этот вид спорта полезен тем, кто много времени проводит за компьютером. Глаза постоянно перенапрягаются и устают. При игре в теннис происходит тренировка глазных мышц, потому что глаза должны следить за быстрым движением шарика, а также успевать реагировать и, при этом, еще наблюдать за действиями оппонента.

Бесспорно, «пинг-понг» отлично влияет на координацию движений, ведь нужно успевать отбивать летящий мяч, а для этого без точных и скоординированных движений всего тела просто не обойтись.

Настольный теннис развивает не только личные, но и деловые качества в характере человека.

Настольный теннис также полезен для людей, у которых есть жалобы на сердечнососудистые и дыхательные системы. Оздоровительный эффект, оказывающий положительное влияние именно на эти системы организма, доказан в процессе проведения c рассматриваемой категорией пациентов уникальных уроков по моей авторской методике.

Рассмотрим в чем же смысл. В процессе игры, когда игрок перемещается от одного края стола к другому, на мышцы сердца осуществляется нагрузка, сравнимая с нагрузкой во время бега. Польза тренировки сердца заключается в следующем: чем лучше ты тренируешь сердечную мышцу, тем меньше риск заболеваний сердечно-сосудистой системы, в том числе наступления сердечных приступов. Данная проблема очень актуальна в текущих условиях, так как именно сердечно-сосудистые заболевания занимают первое место среди причин смертности населения.

Какую же пользу настольный теннис оказывает на дыхательную систему организма? Благодаря дыхательным движениям происходит постоянная вентиляция легких, показателем которой является минутный объем дыхания (МОД) - количество 
воздуха, проходящее через легкие за 1 минуту. В покое МОД равен 5-8 л, а при физической нагрузке увеличивается и достигает 150-180 л. Обычно в покое человек потребляет 200300 мл кислорода в минуту. Во время игры в теннис потребление кислорода возрастает до 2-3 л/мин. И это закономерно. Мышечная работа немыслима без увеличения газообмена, поскольку энергия черпается в процессе окисления органических веществ. Даже при небольших физических нагрузках изменения дыхания четко выражены. При легкой работе обмен газов возрастает в 2-3 раза, при тяжелой - в 20-30 раз. Не занимающийся спортом человек делает 14-18 дыханий в минуту. При игре в теннис этот показатель может составлять 30-40. При значительной физической нагрузке легочная вентиляция увеличивается, в результате чего возрастает проникновение кислорода в кровь. При этом из каждого литра вдыхаемого воздуха кислорода используется больше (4-6\%), чем в покое (3-4\%). При увеличении нагрузок возрастает и скорость кровотока. Так, в покое за 1 минуту через сердце проходит 4-5 л крови. А вот при игре в теннис оно способно перекачивать до 35 л крови в минуту. На циркуляцию крови большое влияние оказывает и частота сердечных сокращений (ЧСС). В покое ЧСС колеблется от 50 до 80 уд/мин, при нагрузке значительно возрастает. Так, у теннисистов при разминке ЧСС составляет 120140 уд/мин, после подачи с выходом к сетке и короткого розыгрыша очка - 150-170 уд/мин, после упражнения «восьмерка» на задней линии - 172-190 уд/мин. Приведенные примеры показывают, что нагрузка у теннисистов-спортсменов во время соревнований и тренировочных занятий довольно большая. Она сопровождается и высокими пульсовыми показателями.

Также уникальность настольного тенниса заключается в том, что улучшается и зрительная система человека. А это особенно актуально для тех, кто много времени проводит за компьютером, например, работники IT сферы. В следствие регулярной работы за компьютером, они постоянно перенапрягаются и устают. При использовании моей авторской методики игры в настольный теннис происходит тренировка глазных мышц. Рассмотрим процесс подробнее. В ходе игры глаза должны следить за быстрым движением шарика, а также реагировать и при этом еще наблюдать за действием оппонента. То есть, глазные мышцы должны быть сфокусированы на нескольких разных точках. И по моей авторской технологии для их тренировки, в ходе разминки, я 
демонстрирую такую уникальную фигуру касания мяча, в которой оппонент должен отбить мяч.

Положительное влияние настольный теннис оказывает и на бизнес, а точнее на бизнесменов и предпринимателей, которые регулярно находятся в ситуациях, когда принимать решение приходится практически молниеносно. Теннис - это очень быстрый спорт, ситуация может меняться буквально за доли секунды. Поэтому здесь нужно уметь принимать правильные решения, практически не раздумывая. У бизнесменов, имеющих такое хобби, как настольный теннис, есть определенные преимущества.

\title{
A List of References, Patent and Licensing Information
}

1

United States Patent

$10,065,068$

Wilson

September 4, 2018

Adjustable ankle rehabilitation apparatus

\begin{abstract}
Various embodiments provide an adjustable ankle rehabilitation device for rehabilitating torn ligaments associated with a sprained ankle. The rehabilitation device can include a planar platform secured to a shoe, and a balancing rail adjustably attached to the bottom of the platform and extending fore to aft. The balancing rail is configured to selectively place a desired amount of stress on the medial muscle or, alternatively, the lateral muscle by adjusting the balancing rail from side-to-side. The device can include adjustable fasteners to secure the balancing rail at a desired position adjacent the bottom of the platform.
\end{abstract}

United States Patent

$9,616,283$

Heineck, et al.

April 11, 2017

Therapeutic device

\section{Abstract}

A low stress therapeutic device is provided by utilizing foot plates and guide rails having operationally tracking surfaces of a low coefficient of friction supported by a platform. 
The device includes a rail stabilizer equipped with extending longitudinally recess or slot and a slideably mounted foot plate having upon its underside a longitudinal projection slideably retained within the rail recess. The therapeutic device may be designed to operate under relatively effortless strain at a low coefficient of friction. The therapeutic device is useful for knee replacement, stroke victims, ACL repair, and other therapeutic treatments requiring a nominal initiating effort of movement for rehabilitation. The device may be provided as a one or two footed device of a light weight particularly useful in a patient sitting or lying position. The foot plates may be appropriately equipped with longitudinally underside tracking guides reciprocating sliding within longitudinal slots provided by a tracking rail.

Wearable power assistive device for hand rehabilitation

\begin{abstract}
A wearable power assistive device for hand rehabilitation includes a hand brace having an external platform and an internal platform connected to and spaced inwardly from the external platform. Five finger assemblies are adjustably mounted on and extending from the distal end of the external platform. Each finger assembly includes a proximal follower assembly for a metacarpophalangeal joint. Five motors are used to actuate the five finger assemblies respectively. Each motor is mounted in close proximity to the external platform and has one end connected to the external platform and another end coupled to its proximal follower assembly by a ball joint in order to facilitate transfer of force and minimize mechanical stress on the other parts of the device.
\end{abstract}

4

United States Patent

Rasmussen

August 14, 2007

Variable resistance aquatic device and methods of using the same

\begin{abstract}
An aquatic device is usable in an aquatic environment for a variety of purposes, such as physical therapy, rehabilitation, and/or exercise. The aquatic device permits a person to simulate a walking or running gait cycle in the aquatic environment, reducing the stress/strain
\end{abstract}


associated with walking or running on the ground. An aquatic device includes a foot-receiving member rotationally coupled to a fin member. The fin member, when in an extended position, provides increased resistance as the person attempts to walk or run in the aquatic environment. During a walking or running gait, the fin member moves into a folded position, thus reducing the resistance of the water on the aquatic device. The aquatic device is adaptable and modifiable to have varying shapes, designs, sizes, resistance levels, and/or other aspects.

\title{
5
}

United States Patent

$6,056,613$

Pike

May 2, 2000

Multi-purpose floatation device for recreation, exercise, instruction and rehabilitation purposes

\begin{abstract}
A recently popular form of exercise and therapy, aquatic exercising devices present unique operating conditions to the body because of their use of water resistance and their buoyancy. By making proper use of water resistance, such devices can provide the body with excellent muscular and cardiovascular training, at the same time, the buoyancy offered by these devices eliminates the stress and injuries associated with the jarring impact of such landbased exercises as running and aerobics. It is also an object of the present invention to provide an aquatic exercise devise that is a singular unit. The inventor began attending a water aerobic class in 1995 for health reasons. Exercising in the water took most of the pain out of the movement, but the inventor found that she was still hurting herself. She sought to reach a truly weightless state in which to condition her body. She tried the various devices provided by the pool facility but none proved effective in granting her the non-impact workout she was determined to find. With a problem to solve the inventor experimented, altered and designed a new and improved floatation device that is uniquely different in its adaptability to numerous applications. A uniquely different floatation device this invention goes beyond the restrictive designs of prior art designed to address one or another aspect of aquatic safety, exercise, rehabilitation or recreation. This invention adapts to usage in a multitude of expressions from water yoga, a unique synergy of ancient eastern culture and modern day technology; to aqua aerobic exercises incorporating cardiovascular enhancement activities; rehabilitation of physical injury or illness; as well as addressing the basic aspects of water safety and learning how to swim. A floatation device for various exercises, instruction, rehabilitation, therapeutic and/or recreational purposes; this invention provides floatation support as no other product on the market because of its unique design and flexibility and the multiple number of ways in which it can be used. With this invention its possible to float supine, moving through various water yoga relaxation movements and stretches; ride it like a bicycle seat; sit on it like a swing; wrap it around the torso and clip it on for deep water workout and/or for those who are uncomfortable in water, but who must get in for health and/or rehabilitation purposes; hold it with hands; slip it under arms, front to back, or back to front; all to move through various exercises for health, rehabilitation and fun. The variation is used to provide superior floatation in a clip on
\end{abstract}


style. With this invention secured around the torso, up the chest and around the back of the neck, the wearer is provided with no-hands support. While wearing the invention the wearer can float forward to swim and learn strokes; tread water in an upright position; and/or float supine; all with complete range of motion of limbs and/or torso. This variation of the invention can be utilized in swimming instruction, pool safety, rehabilitation, recreation, instruction and general poolside safety.

6

United States Patent

Bigelow, et al.

December 19, 1995

Treadmill for use with a wheelchair

\begin{abstract}
An exercise device for the occupant of a wheelchair acting as a treadmill which may be used for cardiac stress testing, cardiac or stroke rehabilitation, fitness training, aerobic training or educational/physical games, with the device including a generally inclined ramp having parallel sides, a forward entrance portion, a movable dolly mounted on rails on the sides of the ramp, the dolly having a pair of laterally movable caster capture plates with openings to receive the front casters of a wheelchair and angular rods cooperating with the wheelchair drive wheels acting to adjust the lateral spacing of said plates, locking means for the dolly to retain it in its forward position, separate locking means for locking the dolly in its rearward position when a wheelchair has been moved onto the ramp into operative position, a pair of enlarged openings adjacent the rear edge of the ramp, and a pair of longitudinally movable rollers beneath the ramp and movable between a rear retracted position allowing the wheelchair drive wheels to be partially received in the openings and a forward position under the drive wheels to engage and lift the drive wheels so that the user can manually rotate the wheelchair drive wheels to rotate the rollers and provide signals to a control apparatus for the desired type of training, testing or rehabilitation.
\end{abstract}

7

United States Patent Application

20130261514

Kind Code

TSUI; Michael Kam Fai ; et al.

October 3, 2013

WEARABLE POWER ASSISTIVE DEVICE FOR HAND REHABILITATION

Abstract 
A wearable power assistive device for hand rehabilitation includes a hand brace having an external platform and an internal platform connected to and spaced inwardly from the external platform. Five finger assemblies are adjustably mounted on and extending from the distal end of the external platform. Each finger assembly includes a proximal follower assembly for a metacarpophalangeal joint. Five motors are used to actuate the five finger assemblies respectively. Each motor is mounted in close proximity to the external platform and has one end connected to the external platform and another end coupled to its proximal follower assembly by a ball joint in order to facilitate transfer of force and minimize mechanical stress on the other parts of the device.

8

United States Patent Application

20120329611

Kind Code

Bouchard; Marc ; et al.

December 27, 2012

Motorized Lower Body Rehabilitation Device and Method

\begin{abstract}
Disclosed is a motorized rehabilitation apparatus and method for disabled, impaired or injured individuals, which trains a proper gait, increases blood flow, relieves stress, and reconditions lower body muscles and joints. The device comprises a powered stationary bicycle having a seat, handle grips, and rotating foot pedals that receive motive input from an electric motor and user input. The device further includes a pair of thigh braces that are connected together between the user's thighs via a hingeable link and chain that controls and trains an individual's limbs through the pedal rotation. The disclosed method further combines the present bicycle device for rehabilitation in conjunction with visual stimuli in the way of a three dimensional television display that stimulates endorphins, relieves mental stress and allows the motive input from the bicycle and mild user input to exercise the limbs of a user without focusing on the rehabilitation activity.
\end{abstract}

9

United States Patent Application

20070093153

Kind Code

Rasmussen; Scott K.

April 26, 2007

Variable resistance aquatic device and methods of using the same

Abstract 
An aquatic device is usable in an aquatic environment for a variety of purposes, such as physical therapy, rehabilitation, and/or exercise. The aquatic device permits a person to simulate a walking or running gait cycle in the aquatic environment, reducing the stress/strain associated with walking or running on the ground. An aquatic device includes a foot-receiving member rotationally coupled to a fin member. The fin member, when in an extended position, provides increased resistance as the person attempts to walk or run in the aquatic environment. During a walking or running gait, the fin member moves into a folded position, thus reducing the resistance of the water on the aquatic device. The aquatic device is adaptable and modifiable to have varying shapes, designs, sizes, resistance levels, and/or other aspects.

10

United States Patent Application

20060211937

Kind Code

Eldridge; Robert

September 21, 2006

Garment to facilitate use of a portable monitor device

\begin{abstract}
A garment configured to hold a portable medical device, and more particularly to a modified upper garment to hold, secure and conceal a heart monitor while allowing easy and unobtrusive access to cardiac lead points on a patient. The garment has an exterior pocket for a monitor. It further has a plurality of openings to allow attachment of monitor leads on a patient without the need to remove the garment. The openings may also have closure means. The garment provides modesty, comfort, durability and an attractive appearance. The garment may be configured for use in all cardiac rehabilitation situations including exercise and stress testing. The entire garment is made of $\mathrm{x}$-ray transparent materials.
\end{abstract}

11

United States Patent Application

20060142680

Kind Code

Iarocci; Michael Anthony

June 29, 2006

Active assist for the ankle, knee and other human joints

\begin{abstract}
A human joint assist device that applies a torque at the joint to assist physiological exertion forces, that is the load carrying task of the joint and surrounding muscles, tendons, and
\end{abstract}


ligaments. The application of this device reduces the physiological exertion force requirement, and may be adjusted with respect to assist level, to suit the issue associated with joint motion and is useful for joint rehabilitation and sports activities. Among other things, this results in a reduction of physiological exertion force in a fashion that makes it easier to extend the levers (long bones) associated with extension against a given resistance. For example, standing from a squatted position with the assist of this device reduces the stress on physiological members associated with joint articulation.

12

United States Patent Application

20180001172

Kind Code

SUTTA; Peters ; et al.

January 4, 2018

STRUCTURE OF ACCESSORY ELEMENT FOR EQUIPMENT OF FLOORBALL TRAINING COURT AND USE OF IT FOR FORMATION OF FLOORBALL SIMULATOR

\begin{abstract}
The invention refers to the equipment of the training rink for floorball, manufacturing of exerciser structural element, applying concept of tennis racket stringing. Proposed design of subsidiary element for floorball rink arrangement characterised with that it is made as latticework formed by: two parallel end plates; several threaded rods as stiffening members; two elastic string structures disposed in two parallel planes, at that each of it presents one side of mentioned latticework and provided with: --holes for fastening threaded rods which assure rigidity and load bearing capacity of the subsidiary element frame structure; --holes for crisscross stringing in two parallel planes and string fastening at mentioned end plates independently one from another.
\end{abstract}

13

United States Patent Application

20160296815

Kind Code

Pindrik; Michael

October 13, 2016

More To Bouncing Ball

\begin{abstract}
Easy to assemble and disassemble gaming apparatus that allows a single player to play a game comparable to Tennis and/or Ping Pong in a limited space environment The proposed game apparatus also allows a single player to perfect his or her skill.
\end{abstract}


14

United States Patent Application

20070238561

Kind Code

A1

$\mathrm{Hu}$; Liang-Fa

October 11, 2007

Structure of toy tennis racket

\begin{abstract}
Structure of toy tennis racket, which mainly improves composition of hitting face of toy tennis racket; it stretches string that one side is adhesive across holes around head of tennis racket in horizontal and longitudinal to make network, so that one side of this network is adhesive face and another side is the hitting face; such combination makes hitting face of toy tennis racket that can produce rebound force owing to the flexible network, furthermore, such racket may provide best ventilation effect to reduce wind resistance, you can hit ball easily as if playing with real tennis racket.
\end{abstract}




\title{
Philosophical-Mathematical Paradox of Dots
}

\author{
Hikmat N. Vazirov, Ph.D, \\ Fikrat H. Vazirov-Kangarli
}

\begin{abstract}
For the first time it was established, that geometric line constructed from dots is not solid, but a dashed line. And there can `t be solid lines without voids. The same words can be said about surfaces and planes. It is shown, that rational and irrational numbers are qualitatively different from a philosophical point of view and therefore not comparable. For this reason, they can't be placed on the same numerical axis. New mathematical-philosophical paradoxes had been considered. Today it is commonly supposed, that physical continuum is solid, continuous, without voids. It is shown, that continuum is having holes in truth. And the interaction of the holes of the continuum with its dots is the source of the philosophical movement. For the first time a new concept of philosophical freedom (archefolia) has been proposed in the article. To explain the essence of this new concept, the authors chose the methodology of mathematics.
\end{abstract}

Бог создал натуральные числа; всё остальное - дело рук человека. Л.Кронекер. Наука не сделает и шага вперед, пока философия не одобрит и не вдохновит ее на это. Т.Манн.

Хорошее начало полдела откачало. Поговорка. Великий оратор похож на заику. Дао де изин.

Наука не только должна находить и выяснять необходимые, общеполезные явления и законы мира (по-философски - вещи), но и пробуждать еще спящее сознание, предназначенное для поиска истины. И то обстоятельство, что среди исследователей мало глубоких и поэтому мало понимающих людей не повод заниматься только поверхностными проблемами и держать науку в дремоте. Поэтому нужно понять, что без правильных философских рассуждений и рефлексии найти истину будет невозможно. Но редко кто задумывается о том, что языков рассуждений может быть много, например, язык философии, язык математики, языки физики, права, экономики, формальной логики, бытовой язык и т.д. И ход, и результат рассуждений будет зависеть от языка. Так, например, в физике число $\boldsymbol{\pi}$ можно заменить на 3,14 , а вместо числа е можно писать 2,7. Действительно, если в измерениях получено 3,14 ампера, то никто не запрещает говорить $\boldsymbol{\pi}$ ампера. То же обычно можно делать и в математике, занимающейся количественными отношениями мира (реальности). Насколько это правильно? Только философия способна ответить на этот вопрос. Но сегодняшнее бездарное горе-руководство ВАК АР, упразднив философию для ученых, исследователей и докторантов, лишний раз доказало свою некомпетентность и неграмотность. Не поняв ценность, важность и необходимость философии для науки, она тем самым погубила будущее науки нашей страны. Ни один исследователь даже при всем желании не сможет избавиться от зависимости науки от философии. И при этом неприемлемые философские идеи, но не кажущиеся таковыми, обязательно приведут к неистинному и неполному пониманию и толкованию законов науки и самого мира. А это, в 
свою очередь, приведет к деградации, как самих исследователей, так и страны. Возможно, упразднить можно почти все, но только не философию! Самый великий гений всех времен Гегель - называл философию абсолютным знанием. И мы с удовольствием солидарны с ним и согласны с тем, что без философии нет деятельности вообще. Без философии нет ни науки, ни политики, ни дипломатии, ни права, ни религии, ни истории, ни этики, ни эстетики, ни искусства... одним словом, ничего. Философия - наиглавнейшее из всех человеческих дел. Недаром Гегель почти каждой из перечисленных областей человеческой деятельности посвятил произведение, например, «Философия права», «Философия религии» или, скажем, «Философия истории». Без философии нет и быть не может управления государством. Очень надеемся, что ВАК срочно исправит свою ошибку. Кодекс чести самураев «Бусидо» гласит: «Совершил ошибку и тут же исправил - считается, что ошибки не совершил». Остается только надеяться, что у ВАК совести все же немножко найдется.

Таким образом, становится понятным, что результат поиска истины зависит от способа рассуждения.

Итак, одной из известнейших проблем математики является древняя проблема происхождения и сущности чисел. Однако, эта проблема по сей день философски не решена. Причина в том, что с античных времен математика признавалась возвышенной наукой, не предназначенной для исследования природы, и поэтому на практике в экспериментах не использовалась. Поэтому ошибки и неправильности в самой системе и началах математики без экспериментов оказывались незаметными. Но эти неправильности приводили к неверным результатам уже впоследствии. И эти ошибки в системах и началах математики дают о себе знать и сегодня тоже. Поэтому Нобелевский лауреат Макс Лауэ в своей «Истории физики» пишет: «Из некоторых дошедших до нас высказываний Платона (427-347 до н.э.) мы узнаем о совершенном пренебрежении ко всякому эмпирическому исследованию. Любые попытки «осквернить» возвышенную науку - математику применением ее за пределами области чистых идей встречали резкое порицание. Именно с этим связано то, что Аристотель (384-322 до н.э.) в своей величественной системе науки дал в области естествознания логический или чаще только софистический анализ понятий, довольно некритически выведенных из поверхностно установленных фактов. Даже такой гений, как Архимед, не имел значительного влияния. Мы не знаем систематического исследования природы ни в древности, ни в средние века» [1]. И с развитием науки эти неправильности в системе математики и, в частности, в проблемах чисел, тоже развивались, расширялись и углублялись. И сегодня на данном этапе развития науки эта философская физико-математическая проблема приобрела новую актуальность, актуальность более высокого уровня [2]. Поэтому сегодня бросить новый взгляд на эту проблему - проблему чисел - является философской необходимостью.

Из элементарной математики известно, что числа удобно отображать на числовой прямой (оси). Выбрав две произвольные точки на этой прямой (удобно выбрать точку 0 и точку 1), устанавливают единицу длины, равную расстоянию между ними. Т.е. длина отрезка между точкой 0 и точкой 1 есть единица длины. И числа (точки), выбранные на этой числовой оси, будут расположены на каком-то расстоянии от точки 0. При этом это расстояние будет или 
соизмеримым с единицей длины, или несоизмеримым. Соизмеримым длинам отвечают рациональные числа. Это означает, что существует какой-то маленький отрезок на единице длины, из которого путем многократного повторения в точности могут быть получены и единица длины, и длина, соответствующая любому рациональному числу. Но, так получилось исторически, что на числовой оси расположили также такие числа, расстояния до которых никак не могут быть соизмеримы ни с единицей длины, ни с этим меленьким отрезком, каким бы маленьким он ни был. Такие числа называются иррациональными. Повторимся, расстояние от точки 0 до этого числа оказывается несоизмеримым ни с единицей длины, ни с этим маленьким отрезком. Частным случаем таких чисел являются трансцендентные числа (от лат. transcendere - переходить, превосходить). И размещение трансцендентных чисел на общей числовой оси приводит к любопытным парадоксам, на которые раньше внимания не обращали. Так, известно, что число $\boldsymbol{\pi}$ - трансцендентное число, т.е. это число не может быть корнем алгебраического уравнения, например, уравнения $\boldsymbol{x}^{2}=$ $\boldsymbol{\pi}$. Т.е. не существует такое число, квадрат которого в точности равен $\boldsymbol{\pi}$. На самом деле, $\boldsymbol{x}^{2} \neq$ $\boldsymbol{\pi}$. Да и само число $\boldsymbol{\pi}$ не имеет точного значения. Следует обратить внимание: точное значение $\boldsymbol{\pi}$ не существует! Т.е. речь не о том, что какое-то число в квадрате дает почти $\boldsymbol{\pi}$, т.е. приблизительно равно $\pi$, а том, что такого числа не существует в принципе. И нельзя утверждать, что это число есть $\sqrt{\pi}$. Это было бы тавтологией. Т.е., на самом деле, нет числа, квадрат которого точно равен $\boldsymbol{\pi}$ по той причине, что не может квадрат числа быть равным несуществующему. Но ведь существует функция $\boldsymbol{y}=\boldsymbol{x}^{2}$, считающаяся непрерывной. График этой функции - парабола. Но, в таком случае, на оси ординат на этом графике числу $\boldsymbol{\pi}$ соответствует какое-то число $\boldsymbol{x}$ на оси абсцисс. А этого быть не может, т.к. в таком случае это число $\boldsymbol{x}$ было бы тем числом, квадрат которого равен $\boldsymbol{\pi}$. Но такого числа, как сказано выше, просто не существует. А стало быть, в той точке параболы, ордината которой соответствует числу $\boldsymbol{\pi}$, должен быть разрыв (хоть и маленький, но все же разрыв). Т.е. парабола не является непрерывной линией?!. И таких разрывов на параболе должно быть бесконечно много, причем на любом участке графика, т.к. считается, что трансцендентных чисел бесконечно много на любом отрезке числовой оси. Стало быть, непрерывных линий в математике не существует вообще, даже в теоретических рассуждениях?!. Все они, в лучшем случае, квазинепрерывны, т.е. вроде бы непрерывны. Например, такой же разрыв будет и на той точке параболы, ордината которой соответствует числу е (основание натурального логарифма). Точно такие же разрывы будут наблюдаться, если рассмотрим уравнения $\boldsymbol{x}^{3}=\boldsymbol{\pi}$ или, скажем, $\boldsymbol{x}^{4}=\mathbf{e}$, а также бесконечное количество подобных функций с другими трансцендентными числами.

Или рассмотрим, например, задачу о квадратуре круга. Возьмем круг радиусом равным единице длины. Тогда площадь этого круга в современной общепринятой системе представлений будет $\boldsymbol{\pi}$ квадратных единиц. А квадрат площадью $\boldsymbol{\pi}$ будет иметь сторону длиной $\sqrt{\boldsymbol{\pi}}$. Т.е. задача о квадратуре круга сводится к построению отрезка длиной $\sqrt{\boldsymbol{\pi}}$ в масштабе любой принятой единичной длины. Но по общепринятой сегодня теореме о геометрических построениях, отрезок длины $\boldsymbol{\pi}$ построить невозможно. Т.е. на числовой оси 
отложить числа $\boldsymbol{\pi}$ и $\sqrt{\boldsymbol{\pi}}$ для любого масштаба, для любой принятой нами единицы длины, невозможно в принципе. Вот почему квадратура круга неосуществима.

Таким образом, проблема чисел и, в частности, проблема актуальной бесконечности, все же существует! И эта проблема весьма актуальна!

Однако привычными способами, устоявшимися в сегодняшней системе математики, ответить на возникшие вопросы и решить поставленные нами проблемы и парадоксы представляется уже невозможным, тем более что математику наукой признавать нельзя. Так, известные математики Э.Беккенбах и Р.Беллман начинают свою книгу «Введение в неравенства» словами: «Математику называют тавтологической наукой: другими словами, о математиках говорят, что они тратят время на доказательство того, что предметы равны самим себе. Это утверждение (свойственное философам) весьма неточно по двум причинам. Во-первых, математика, несмотря на свойственный ей научный язык, не является наукой; скорее ее можно назвать искусством, поскольку математическое творчество родственно художественному творчеству. Во-вторых, основные результаты математики чаще выражаются неравенствами, а не равенствами» [3]. Поэтому нужна правильная философия, являющаяся основанием и началом всех наук [4]. Недаром Евклид назвал свою книгу именно «Начала», потому что правильное начало важнее всего: хорошее начало - это уже половина всего дела. Так что же принято в современной системе науки и математики? Попробуем разобраться.

Первая книга «Начал» Евклида начинается словами: «1. Точка есть то, что не имеет частей. 2. Линия же - длина без ширины. Концы же линии - точки. Поверхность есть то, что имеет только длину и ширину» [5]. Смысл этих определений, возможно, заключается, в частности, в том, что и диаметр точки, и ширина линии, и толщина поверхности (плоскости) равны нулю. Кстати, из определения Евклида о том, что конец линии - точка, сразу возникает философский вопрос о том, а что находится на этой линии перед этой точкой. Правильный ответ такой: перед последней точкой находится предпоследняя точка. И сразу возникает вопрос: последняя и предпоследняя точки соприкасаются или нет? Но все равно, советские учебники по математике эти определения правильными не признавала. Более того, они утверждали, что ни точка, ни прямая определений не имеют вообще. А в советских учебниках по геометрии базовыми единицами являлись прямая и отрезок. Эти учебники давали следующие определения: «Отрезком называется часть прямой, которая состоит из всех точек этой прямой, лежащих между двумя данными ее точками. Эти точки называются концами отрезка. (Т.e., фактически считалось, что линия - это геометрическая фигура, состоящая из соприкасающихся точек - $\boldsymbol{A в m}$.). Окружностью называется фигура, которая состоит из всех точек плоскости, равноудаленных от данной точки. Эта точка называется центром окружности. Геометрическим местом точек называется фигура, которая состоит из всех точек плоскости, обладающих определенным свойством» [6]. Диаметр точки при этом, конечно же, предполагается равным нулю. Дадим наше определение линии и посмотрим, что из этого получится: «Линия - это целокупность точек, соприкасающихся то́лько с двумя соседними (кроме начальной и конечной)». Покажем это наглядно на рисунке 1. Из рисунка видно, что любая точка соприкасается только с двумя соседними. Исключение составляют 
лишь начальная и конечная точки, каждая из которых соприкасается только с одной точкой. Если уменьшить геометрические размеры (диаметры) этих «точек» (кружочков), оставив неизменными координаты их центров, то между «точками» окажутся пустоты (дырки). Если после этого «точки-кружочки» снова приблизить до их касания, а затем снова уменьшить их диаметры, снова получим пустоты между ними. И так до бесконечности. Наконец, в пределе, когда «диаметр» кружочка станет равным нулю (и кружочек превратится в настоящую геометрическую точку), то окажется, что эти, теперь уже настоящие точки, не смогут соприкасаться, а будут или сливаться друг с другом (одна точка ляжет на другую), или находиться на каком-то расстоянии друг от друга, не касаясь друг друга. Т.е. между любыми двумя точками окажется промежуток. А это значит, что понятие касания для геометрической точки с философской точки зрения исчезнет? Ведь касание означает, что одна часть вещи дотрагивается до какой-то части другой вещи, а другие части этой вещи - не дотрагиваются. Но ведь другой части у точки нет. Потому и касания нет.

Отсюда следует вывод: касательные, о которых говорилось в планиметрии - не совсем касательные, а возможно, лишь кажущиеся касательные, вернее, предполагаемые касательные, т.е. являются всего лишь конструктами, не имеющими референта. Не могут касаться друг друга вещи, не имеющие геометрического размера, вернее, если их размеры (диаметры) равны нулю. Они могут находиться или одна на другой, или находиться рядом друг с другом, не касаясь друг друга. А это значит, что математическое понятие непрерывности естественным и объективным образом исчезает, т.е. так же, как и понятие касательной, превращается в конструкт без референта. Получается, что непрерывной (сплошной) геометрической линии нулевой ширины без разрывов (пустот, промежутков, дырок) быть не может вообще. Но даже если точки соприкасались бы, то, все равно, учитывая, что диаметр точки равен нулю, сколько бы соприкасающихся точек не ставить рядом, все равно, их суммарная длина будет равна нулю и линия не получится, т.к. $0+0+\ldots+0=0$.

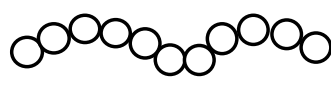

Рис. 1

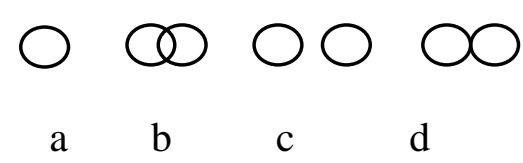

Рис. 2

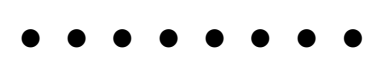

Рис. 3

Линия может получиться из точек и быть непрерывной лишь в случае, если она имеет ширину, т.е. если каждая «точка», из которой состоит эта «линия», имеет размер, больший нуля. Но, в таком случае, это уже будет не точка. А «линия» будет уже не линией, а геометрической фигурой, имеющая площадь, например, полоса, лента или круг (но не окружность). В случае же если ширина линии равна нулю, то значит, линия - прерывистая (т.е. содержит пустоты, дырки). В противном случае линия не получится. А если же «линия» все же име́ет ширину, то конец ее не может быть настоящей точкой, а будет кружочком, как на рис. 1. 
Здесь уместным будет сказать, что понятие «не имеет размера» с философской точки зрения не вполне корректно. С философской точки зрения все может иметь размер. Просто размер какой-то вещи или чего-то может быть равен нулю. Геометрическая точка и есть именно такая философская вещь, пространственный размер которой равен нулю. Т.е. точка безразмерна (имеет нулевую размерность). Поэтому, думается, Евклид ошибся, считая, что линия - это то, что не имеет ширины. На самом деле, вернее, на наш взгляд, с философской точки зрения, у линии ширина есть, но эта ширина равна нулю. Но, не имея никакого права критиковать этого великого гения, и ради истины и справедливости скажем, что Евклид и не говорил, что диаметр точки равен нулю. Он говорил только, что точка не имеет частей.

Аналогичными философско-математическими рассуждениями можем прийти к логическому умозаключению о невозможности сплошной плоскости. Любая плоскость, не обладающая толщиной (т.е. когда ее толщина равна нулю), должна быть равномерно дырявой. Сплошной (без дырок) может быть лишь «плоскость», обладающая толщиной, большей нуля. Т.е. любая плоскость (и геометрическая, и физическая) содержит бесконечное количество дырок, по количеству, возможно, равному количеству точек этой плоскости. Отсюда философский вывод: физическое пространство тоже дырявое...

Таким образом, как приведенные выше определения, так и наше определение линии неверны!?.

Итак, наши логические философско-математические рассуждения привели к умозаключению: плоские геометрические фигуры, например, окружность - прерывистые (дырявые), пунктирные «линии»! Такой же прерывистой (дырявой) является и любая геометрическая фигура, и любая линия. Это можно доказать логически, опираясь даже на один только логический закон исключенного третьего. Так, если считать (принять), что линия существует (причем не важно, объективно или лишь мысленно), то должно существовать лишь два возможных утверждения: 1) точки, из которых состоит эта линия, соприкасаются; и, 2) точки, из которых состоит эта линия, не соприкасаются. Из этих двух возможных утверждений только какое-то одно может быть истиной, а другое обязательно должно быть ложью. Если предположить, что истинно первое утверждение, а именно то, что точки соприкасаются, то учитывая то, что размер точки равен нулю, то, сколько бы соприкасающихся точек не ставить рядом линия не получится, т.к. $0+0+\ldots+0=0$. Но, мы же считаем (приняли), что линия существует. Значит, первое утверждение ложно. Отсюда выходит умозаключение: истинным является второе утверждение. Т.е. утверждение о том, что точки, из которых состоит линия, не соприкасаются - является истинным. Но тогда линия - прерывистая. Доказано!!!

Если же считать (принять), что линия не существует, то рухнет вся геометрия, которая на линиях и держится, и говорить не о чем. Но геоетрия же существует. Таким образом доказано: любые линии прерывистые, дырявые, пунктирные, т.е. являются отточиями (рис. 3 )...

Получается, что в евклидовой планиметрии вообще не может быть ни касательных, ни сплошных (без дырок) линий? Плоские геометрические фигуры или их части принципиально 
не могут касаться друг друга и быть сплошными, т.е. без дырок. Они могут лишь или лежать одна на другой (рис. 2, а), или пересекать одна другую (рис. 2, b), или же находиться на определенном расстоянии одна от другой (рис. 2, с). Касаться же, как на (рис. 2, d), они не могут.

И если рассмотреть ту самую числовую ось, то она тоже должна быть равномерно прерывистой (равномерно дырявой). И, учитывая то, что числовую ось придумали именно для чисел, известных на то время (т.е. для натуральных и дробных чисел, которые сегодня называют рациональными числами), и считали, что эти числа расположены на точках оси, мы должны думать, что те известные (рациональные) числа находятся именно на точках этой оси, а не в «дырках». А иррациональным «числам» на этой оси вообще-то места нет в принципе. Но до сих пор они туда были втиснуты. Это аналогично тому, что на ось, скажем, температур, втиснули время или расстояние. Но, если все же, иррациональные «числа» тоже силком загнать в эту ось (именно это положение в системе сегодняшней математики и существует), то придется предположить, что иррациональные «числа», частным случаем которых являются трансцендентные «числа» (например, $\boldsymbol{\pi}, \mathbf{e}, \boldsymbol{\alpha}^{\mathbf{n}}$ для некоторых $\alpha$ и n), расположены как раз в дырках этой прямой?

Итак, получился неизвестный ранее философско-математический парадокс точек, который можно сформулировать, например, так: сплошная линия существует, и она состоит из соприкасающихся точек, но сплошная линия не существует, т.к. точки касаться друг друга не могут, и поэтому это не линия, а что-то вроде пунктира, т.е. нечто разорванное (с дырками). Этот парадокс можно сформулировать иначе: линия образу́ется (состоит) из соприкасающихся точек, но линия не́ образуется, т.к. точки соприкасаться не могут, но даже если точки соприкасались бы, то линия все равно не образовалась бы, т.к. диаметр точки равен нулю и их сумма была бы равна нулю. Можно и так: точки соприкасаются, и поэтому образуется линия, но они не соприкасаются, т.к. соприкасаться не могут, и поэтому линия не образуется. И разрешить этот парадокс или апорему, представляется достаточно сложным.

Здесь как раз уместным будет дать объяснение понятию иррационального «числа». Иррациональное «число» - это «число», которое не может быть получено делением одного натурального числа р на другое натуральное число q. Например, квадратный корень из числа 2 является иррациональным «числом» (т.к. никак не может быть получен делением одного натурального числа $\mathbf{p}$ на другое натуральное число $\mathbf{q}$ ), и является бесконечной непериодической десятичной дробью. Но это «число» явля́ется корнем алгебраического уравнения $\mathrm{x}^{2}=2$. В то же время, имеются такие иррациональные «числа», которые корнем алгебраического уравнения являться не могут. Такие иррациональные «числа» называются трансцендентными «числами». Таковыми являются, например, числа $\boldsymbol{\pi}$, е, десятичные логарифмы всех целых чисел, не кратных 10, или числа вида $\mathbf{a}^{\mathbf{b}}$, где, $\mathbf{a}-$ алгебраическое число, не равное 0 и 1 ( $\mathbf{a} \neq 0 ; \mathbf{a} \neq 1)$, a $\mathbf{b}-$ иррациональное алгебраическое число. Есть бесконечно много и других трансцендентных чисел.

Становится понятным, что любые две философские вещи, имеющие пространственный размер, могут находиться (располагаться) по отношению друг к другу только четырьмя 
способами, как показано на рис. 2: а) конгруэнтно, т.е. одна целиком лежит на другой; b) пересекаться, т.е. одна частично лежит на другой; с) одна находится на каком-то расстоянии от другой, не касаясь ее. Положение же, изображенное на рис. $2 \mathrm{~d}$ - всего лишь абстракция. Но ведь у точек (материальных, физических, геометрических, ..., и вообще, любых точек) пространственные размеры равны нулю (т.е. их диаметры равны нулю). Поэтому они касаться друг друга не могут, а могут быть только в двух положениях: либо одна точка полностью лежит на другой, (рис. 2 а), либо между ними имеется какое-то расстояние (рис. 2 c). Дело в том, что, повторимся, касание одним телом другого означает соприкосновение, «дотрагивание» наименьшей части первого тела наименьшей части второго тела. Наименьшая же часть - это точка, а у точки частей нет по определению. Поэтому точки соприкасаться не могут. Принципиально. И вообще, не ограничивая общности, вещи (в философском смысле), не имеющие частей (пространственный размер равен нулю в любом направлении), соприкасаться не могут. Они или лежат одна на другой, или же находятся на каком-то расстоянии друг от друга. Явление соприкасания для вещей, размер которых равен нулю, с философской точки зрения становится дистинктивно невозможным. Или, говоря философским языком, две точки не могут иметь непосредственного отношения друг к другу. Но они имеют отношение к рядом стоящим дыркам. Но по правилам отношения транзитивности: если $\mathrm{xRy}$ и $\mathrm{yRz}$, то $\mathrm{xRz}$, где $\mathrm{R}$ - символ философского или логического отношения. Поэтому, если точка имеет отношение к ближайшей дырке, а эта дырка к следующей точке, то первая точка имеет отношение к той второй точке через дырку между ними. Получился еще один философско-математический парадокс: точка к ближайшей точке отношения не имеет, но точка к ближайшей точке отношение име́ет (через дырку). Так через дырку и передается отношение и движение.

И, если все же силой загнать (втиснуть) иррациональные «числа» в ось для рациональных чисел (как уже сказано выше, именно такое положение в сегодняшней системе математики имеет место), то из сказанного выше выйдет гипотетическое философско-математическое умозаключение: количество иррациональных «чисел» (мощность или число элементов системы иррациональных «чисел»), уж по крайней мере, не меньше количества рациональных чисел. При этом если рациональные числа находятся на точках той известной условной числовой оси, то иррациональные числа должны быть между точками (в дырках) этой оси (хотя вообще-то им на этой оси места нет - для них нужна другая ось).

Таким образом, для неправильной, но сегодня принятой, системы одной единственной числовой оси получилась философско-математическая теорема: между любыми двумя рациональными числами на общепринятой сегодня числовой оси находится хотя бы одно иррациональное число и, в частности, трансцендентное «число». А также возникает гипотеза: эти два вида чисел - рациональные и иррациональные - распределены на принятой числовой оси неравномерно, неравноплотно, неравномощно или неравноколичественно!?. Почему? Постараемся логически обосновать эту гипотезу (не хотим называть это теоремой). Мы уже объяснили, что, если пространственный размер точки равен нулю, т.е., говоря принятым сегодня языком, размера нет, тогда эти точки соприкасаться друг с другом не смогут, и поэтому линия не получится. Но даже если они соприкасались бы, то линия все равно не 
образовалась бы, т.к. диаметр точки равен нулю, а сумма нулей равна нулю. Поэтому, для того, чтобы образовалась линия из точек, необходимо считать, что между точками имеются промежутки, дырки. И тут возникает еще один философско-математический парадокс: минимальный размер промежутков между точками должен быть равен размеру точки, но размер промежутков между точками не может быть равен размеру точки, т.к. иначе линия не получится. Этот парадокс возникает потому, что если пространственный размер промежутков между точками равен размеру точки, т.е. равен нулю, то это фактически означает, что этих промежутков нет. Но, как показано выше, промежутки есть. Поэтому, чтобы разрешить этот парадокс, мы должны считать, что размер промежутков (мы их еще назвали по аналогии с физикой полупроводников - дырками) больше нуля, т.е. больше размера точек, а стало быть, в каждую из этих дырок можно втиснуть столько «чисел», что их количество будет больше единицы? При этом на каждой точке числовой оси находится только одно число, и это число - рациональное число. Тогда, в случае, если мы вынуждены будем разместить иррациональные «числа» тоже на этой же прямой (числовой оси), то придется их разместить в дырках этой прямой, хотя этим «числам» там места вообще-то нет. Причем, получается, что количество иррациональных чисел больше (или, по крайней мере, не меньше), чем рациональных чисел, т.к. дырка по размеру больше точки и, поэтому, там может расположиться большее количество «чисел». Если число всех возможных трансцендентных чисел на каком-то отрезке числовой оси бесконечно, тогда пустых (без трансцендентных чисел) дырок, наверное, быть не может. Если же число всех существующих трансцендентных «чисел» конечно, то между точками мо́гут оказаться пустые дырки (без трансцендентных «чисел»). Итак, каждой точке соответствует только лишь одно рациональное число, а каждой дырке, расположенной между двумя стоящими рядом точками, наверное, соответствует бо́льшее количество неоправданно и необоснованно втиснутых туда иррациональных «чисел». Во всяком случае, в каждой дырке количество иррациональных «чисел» больше единицы. А это означает, что если искусственно, т.е. силой, загнать иррациональные «числа» в ось для рациональных чисел, то количество всех иррациональных «чисел» на любом отрезке общепринятой числовой прямой, окажется больше количества всех рациональных чисел. Т.е. получается, что вообще-то количество всех возможных иррациональных «чисел» больше количества всех возможных рациональных чисел. Этот результат, полученный философскими методами, не будет трудной теоремой для математиков.

Предлагаемая нами философская логико-математическая теория, очевидно, применима в любой математике и геометрии, например, геометрии Лобачевского или геометрии Римана.

Итак, повторимся, если точка имеет пространственный размер, равный нулю (т.е. не имеет частей), то, сколько бы точек не ставить рядом - линия не получится. Действительно: $0+0+\ldots+0=0$, и длина будет равна нулю. Поэтому, для того, чтобы из точек все же построить линию, необходимо, чтобы или пространственный размер точки был равен не нулю, а был равен бесконечно малой величине, но большей нуля (но, в этом случае, концы линии не будут точками, а будут кругами или шариками). Или же, если размер точки равен нулю, тогда между точками должны быть 
расположены дырки, т.е. оставаться пустоты, промежутки, т.к. в противном случае линия не образуется. Т.е. реальная линия теперь должна выглядеть как на рис. 3.

Таким образом, вопреки устоявшемуся мнению о сплошных линиях, на самом деле, линия, например, числовая прямая - прерывистая, дырявая конструкция, т.е. напоминает пунктир, а точнее, отточие (рис. 3).

В повседневной жизни используется большое количество чисел. И этого количества действительных (рациональных) чисел полностью хватает, например, для проведения какихто экспериментальных исследований. Но, большие проблемы возникают сегодня, когда речь заходит о философских или теоретических рассуждениях. Например, если нужно точно (именно точно) установить длину $\mathbf{d}$ диагонали квадрата со стороной $\mathbf{b}$, то получим, что $\mathbf{d}=$

$\sqrt{2} \mathbf{b}$. И при этом выяснится, что $\sqrt{2}$ - это и не целое число, и не дробное. На момент открытия, это «число» было «новым видом чисел», и назвали такие «числа» иррациональными числами. Повторимся, отличие их от рациональных чисел, т.е. целых и дробных чисел, в том, что последние можно выразить в виде отношения двух целых чисел, например, $\mathbf{p}$ и q, поэтому их и называют рациональными числами, т.е. полученных делением, отношением. Иррациональные же «числа» потому и называются иррациональными (что в переводе означает «не имеющие отношения»), что их точно получить отношением двух целых чисел р и q невозможно. Сама группа иррациональных «чисел» делится на две части: одна часть - это алгебраические «числа», которые мо́гут быть корнями алгебраического уравнения с целыми коэффициентами, другая часть состоит из «чисел», которые не́ могут быть корнями алгебраического уравнения. Те иррациональные «числа», которые не́ могут быть корнями алгебраического уравнения, называются трансцендентными «числами». Примеры трансцендентных «чисел» приведены выше.

Таким образом, рациональные и иррациональные числа в философском смысле являются разнородными, разнотипными, противоположными, поэтому для их геометрического изображения требуются разные числовые оси. Т.е. эти два вида чисел различны качественно: рациональные числа гомогенны, иррациональные - гетерогенны. Их неодинаковость проявляется в каком-то сходном свойстве, но внутренне, онтологически эти числа друг с другом не связаны. Думается, что противоположность этих чисел как внешняя, так и внутренняя. Эти числа взаимно отрицают, исключают друг друга. Такими же философски противоположными, качественно разными, разнородными, разнотипными, отрицающими друг друга, являются алгебраические и неалгебраические числа, действительные и комплексные числа...

Если бы философски можно было допустить, что числа как вещи сделаны из чего-то, то рациональные числа гомогенны (однородны), т.е. «сделаны» из одного и того же. Поэтому любое из этих чисел может быть получено из других таких же чисел. И поэтому они сравнимые, т.е. одно больше или меньше другого, или равно другому. Комплексные числа негомогенны, они гетерогенны, т.е. «сделаны» из не одного и того же или же не из одного и того же. Поэтому эти «числа» несравнимые. Т.е. нельзя спрашивать, какое из двух комплексных «чисел» больше, а какое - меньше. Ни одно из них и не больше, и не меньше другого. Они несравнимые, т.к. разнородные, качественно разные. Потому и разместились 
они (совершенно неосознанно) не на одной оси, а в разных местах плоскости, образованной двумя разными осями. То же можно сказать и об иррациональных «числах». Ни одно из иррациональных «чисел», в частности, трансцендентных «чисел», не может быть получено из других трансцендентных чисел, если, конечно, не прибегнуть к особым фиктивным, химерным ухищрениям. Кроме всего, принято считать, что действительные, вещественные числа являются частным случаем комплексных «чисел». Тут все зависит от договоренности (научно-философская теория конвенционализма). Если мы договоримся признавать комплексные «числа» чи́слами, тогда действительные числа окажутся частным случаем комплексных «чисел», как и пишут в математических справочниках. Однако ведь действительные числа выражают количество, а сами же эти справочники утверждают, что комплексные «числа», наоборот, количества не выражают! Значит, комплексные «числа» в этом отношении не должны признаваться числами, и, в этом случае, действительные числа не могут признаваться частным случаем комплексных «чисел». Тогда получается, что общее (индуктивное) не выполняет то, что выполняет частное. Философски это невозможно. Таким образом, именно с философской точки зрения, действительные (вещественные) числа не должны признаваться частным случаем комплексных «чисел». Действительно, философским качеством действительных чисел является свойство (физическое качество) выражать количество. А комплексные «числа» не обладают свойством или качеством выражать количество (это утверждают все учебники по математике). Таким образом, необходимо признать, что комплексные «числа» и действительные числа - это разнокачественные в философском отношении вещи. Именно поэтому комплексные числа размещают совершенно неосознанно не на линии, а на плоскости, образованной двумя неравноценными ортогональными числовыми осями - осями действительных и мнимых чисел. Кроме этого, повторимся, каждое рациональное число имеет референта, а комплексное «число»- референта не имеет. Трансцендентные «числа» также референта не имеют. И то, что из одного комплексного «числа» можно вычитать другое комплексное «число» - является философским недоразумением (но, не математическим). Но это недоразумение в сегодняшней системе науки является нормой, и это можно увидеть в любом учебнике.

Возможно, и нуль числом признавать не следует - это всего лишь условное обозначение (знак, символ) отсутствия. Т.е. нуль - это пустое понятие, которое не отображает никаких объектов так же, как, например, понятие «хорда треугольника» или, скажем, «периметр электрона». Т.е. это пустое понятие, пустой класс, т.е. класс чего-то, который не содержит в себе никаких элементов. Например, класс «квадратных треугольников» является пустым классом, т.к. квадратных треугольников не бывает так же, как и треугольных квадратов, хорды треугольника или периметра электрона. И нельзя путать «часть целого» с «частным случаем». Часть целого (например, подшипник трактора) может делать то, что не может целое, а целое (например, трактор) может делать то, что не может часть целого (подшипник). Частный случай же не может совершать то, что не может общее. А общее может то, что может частное, и может то, что не может частное. 
Этими рассуждениями, мы хотели показать, что рациональные и иррациональные числа с философской точки зрения являются разнородными, разнотипными, качественно разными вещами. А их всех в свое время под названием «действительные числа» совершенно необоснованно разместили на одной общей числовой оси. И эта неправильность сегодня продолжается. Т.е. под одним термином «действительные числа» до сих пор некорректно называют на самом деле разнокачественные, взаимоисключающие вещи. Качественное отличие всех тех чисел, которые неосознанно и неудачно подстригли под одну гребенку «действительных чисел», заключается также в том, что часть этих чисел, а именно, рациональные числа, имеют референта. Иррациональные же числа, в том числе, трансцендентные числа, референта не имеют. Они являются только лишь концептами или конструктами. Поэтому в предлагаемой новой системе науки рациональные числа нельзя сравнивать с иррациональными. Будучи разнокачественными вещами в философском смысле, они не подлежат сравнению. Так, нельзя сравнивать, что лучше, телевизор или диван, т.к. они - вещи разнокачественные и поэтому несравнимые. Точно так же нельзя сравнивать арбуз с телефоном, т.к. они вещи разнокачественные. Разнокачественные вещи друг с другом сравнивать нельзя. Точно так же, вещи, имеющие референта, отличаются от вещей, не имеющих референта, качественно, и поэтому не могут быть сравнимыми!

Отсюда получается невероятное умозаключение: $\pi$ (которое сегодня считается равным приблизительно 3,14 ) не меньше 4 и не больше 3 , потому что $\pi$ нельзя сравнивать ни с 3 , ни с 4 , т.к. 3 и 4 являются натуральными числами, а $\pi$ трансцендентное «число»? Т.е. с философской точки зрения это разнородные, разнокачественные вещи. И этот результат тоже парадокс: считается, что $\boldsymbol{\pi}$ равно примерно 3,14 и поэтому $\boldsymbol{\pi}$ больше 3 и меньше 4. Но $\boldsymbol{\pi}$ не равно 3,14 и поэтому его нельзя сравнивать ни с 3 , ни с 4 , потому что $\pi$ и эти два числа разнокачественные вещи. Значит, «число» $\boldsymbol{\pi}$ с философской точки зрения и не больше 3 , и не меньше 4? И утверждение, что « меньше 4, но больше 3» такое же неверное, как и утверждение, что 3,14 метра меньше 4 килограммов, но больше 3 секунд (ни метры, ни секунды нельзя же сравнивать с килограммами: в философском смысле это разнокачественные вещи)? Трансцендентные числа референта не имеют, и, поэтому, они отличаются от рациональных чисел качественно, т.е. это разнокачественные вещи. И попытка сравнить рациональные числа с иррациональными числами также напоминает попытку, например, сравнить человека с его фотографией или телевизором. Это очень важно, поэтому еще раз повторимся. Нельзя сравнивать длину, скажем, с массой, или площадь с силой электрического тока. Это неравнокачественные, разнокачественные вещи. Поэтому нельзя спрашивать, что больше, 5 метров или 20 килограммов. Или, что меньше, 2 кубических метра или 2 ампера. Все они обозначают количественные характеристики разных свойств философской вещи. И поэтому их нельзя сравнивать. Нужно понять, что $\boldsymbol{\pi}$ не является числом не потому, что его не смогли точно измерить, а потому, что оно не может быть точно измерено, т.к. этого точного значения просто не существует, а стало быть и числа такого не существует. Поэтому $\boldsymbol{\pi}$ не выражает количество, а рациональные числа выражают точное количество, и поэтому рациональные 
числа действительно являются числами. Точно так же, выражение $\lg 12=\mathbf{A}$ и выражение

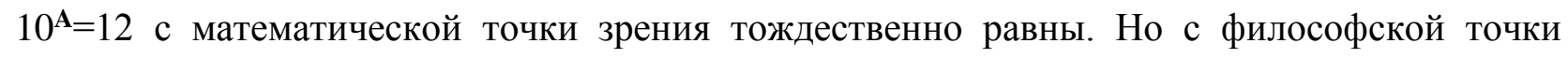
зрения, такие выражения являются фикцией, т.к. нет такого числа А, для которого данные выражения выполнялись бы точно. Такое число А просто не существует. Т.е. с философской точки зрения $10^{\mathbf{A}}=12$ ни для каких $\mathbf{A}$ не выполнимо точно. Но с математической или физической точек зрения это выражение возможно, и А при этом является трансцендентным «числом» «несколько большим единицы». Т.е. с философской точки зрения, на числовой оси для такого «числа» А места нет вообще́, потому, что такое «число» для философа не существует. Но для математика или физика, это «число» существует, и если неоправданно все же расположить это «число» на общепринятой числовой оси, то придется расположить его между 1 и 2.

Продолжая философские рассуждения о сплошных (несплошных) линиях, придем к выводу, что не бывает сплошных плоскостей (т.е. плоскостей без дырок), сплошного объема или сплошного пространства без дырок. Т.е., на самом деле, физический вакуум дырявый, как и плоскость, как и прямая или любая другая линия. И в «дырках» числовой плоскости, наверное, находятся иррационально-комплексные или трансцендентнокомплексные «числа»).

Для дальнейшего разъяснения нашей философско-математической теории или новой системы науки нам понадобится понятие континуума. В математике для геометрической интерпретации действительных чисел континуум представляли точками числовой прямой. Каждая точка этой прямой соответствовала какому-либо действительному числу. Теперь же стало понятно, что если сегодня продолжать принимать за истину правильность числовой оси, то не только каждая точка, но также и дырки между точками будут соответствовать действительным числам (в дырках будут находиться иррациональные числа, которые сегодня пока все еще совершенно необоснованно тоже признаются действительными числами). Но, как показано выше, это не́ правильно. Поэтому для каждого вида чисел необходимо вводить отдельные числовые оси: для рациональных чисел можно использовать ту ось, которую сегодня называют числовой прямой (но, как удалось установить, она дырявая). Для иррациональных «чисел», которые качественно отличаются от рациональных чисел, необходимо вводить свою ось, т.к. им на точках оси рациональных чисел места нет, и в эту ось их неосознанно и необоснованно загнали силой, причем совершенно неоправданно. Поэтому, если уж загонять иррациональные числа в ось рациональных чисел, то придется расположить их в дырках этой оси. Этими рассуждениями мы объяснили неправильность старой системы математики и теории чисел. Даже для отрицательных «чисел» необходимо вводить отдельную ось.

В физике под континуумом понимают пространство-время. Структура физического континуума зависит от плотности вещества, излучения, поля. Физический континуум должен быть охарактеризован или непрерывностью, или прерывностью. Сегодня общепринято, что физический континуум непрерывен, т.е. он сплошной, без пустот, без дырок.

\section{Вопреки общепринятому сегодня, мы утверждаем, что и математический} континуум, и физический континуум, являются прерывистыми, дискретными, т.е. 
содержат пустоты, дырки. И число пустот или дырок хотя и равно числу составных частей матрицы континуума (т.е. точек), но пространственный размер дырок должен быть больше нуля. Если это физический континуум, то материалом матрицы (назовем этот материал основой) является вакуум. Если это математический континуум, то матрицей, т.е. «материалом» континуума, являются числа.

Наши логико-философско-математические рассуждения необходимы были для того, чтобы показать, что точки и дырки, о которых мы говорим - это сущность основы философского движения вообще и движения микрочастиц, в частности. И в частности флюктуаций вакуума. Конечно же, трудно себе представить это, но именно наличие в физическом континууме точек (и дырок между ними), и взаимодействие их между собой через дырки и есть источник философского движения и бытия - свобода (архефолия). Вернее, не наличие, а то, что сам физический континуум состоит из точек и дырок, и является источником движения всего сущего, бытия. И взаимодействие точек с дырками мы назвали архефолией $[<$ гр. arche начало, лат. folleo - ходить взад вперед, болтаться и порт. folia - безумная пляска, шумное веселье].

Гегель считал, что противоречие является, во-первых, основанием любого движения, вовторых, сущностью вещей. Т.е. между точкой и дыркой (являющейся местом отсутствия субстанции-материи-вещества-континуума-вакуума-бытия) возникает диалектическое противопоставление, противоположение, противоречие и взаимодействие. Мы считаем, что противоречие обладает одним очень важным свойством, заключающимся в том, что противоречие между, скажем, двумя вещами, возможно только в том случае, когда одна вещь содержит в себе часть или хотя бы элемент второй вещи. В противном случае противоречие возникнуть не может. Т.е. противоречие может быть только в системе. Так, например, между морем и трактором, стоящим далеко от моря, нет взаимодействия и поэтому противоречия тоже нет. Если же трактор будет находиться в море (в воде), то образуется система моретрактор, и возникает взаимодействие и противоречие, приводящее к коррозии и разрушению трактора. И в сущности противоречия философской вещи кроме двух составных частей (противоположности и взаимопроникновения) должна содержаться третья составная часть, которую мы назвали архефолией. Вернее, архефолия - это сущность противоречия. И именно благодаря этой архефолии и осуществляется взаимодействие противоположностей, т.е. противоречие, приводящее к его разрешению (снятию). Т.е. все сущее дырявое. И, возможно, все могло бы быть в состоянии полного покоя. Но, если что-то приведет к взаимодействию даже всего лишь одной точки с одной дыркой, то это приведет к передаче взаимодействия от одной точки или одной дырки к другим, а затем и всем точкам, и дыркам, а это в свою очередь к вечному движению. Взаимодействие дырок континуума с его точками - архефолия - и есть основа философского движения. Уместным будет сказать, что отличительной особенностью именно диалектического противоречия является то, что, в отличие от формально-логического противоречия, архефолия проявляется именно в предметном противоречии, т.е. в референтах. В конструктах же архефолии, наверное, нет! И, без учета архефолии, опосредствующей противоположности в противоречии, решать диалектические задачи философского движения и развития, а также науки, не удастся. 
Таким же прерывистым является и время. И взаимодействие дырки со своим окружением, т.е. с другими дырками и точками - это та причина, которая приводит и к известному в физике принципу неопределенности, и, наверное, к возможному отделению пространства от времени.

Авторы настоящей статьи, получившие изложенные результаты логико-философскими рассуждениями, уверены, что в ближайшее время физики докажут эти результаты экспериментально. Можно предсказать также, что к известным сегодня четырем силам (взаимодействиям) в природе, а именно, гравитационным, электромагнитным, сильным и слабым, может быть добавлена пятая сила. Эта сила отвечает за так называемую темную материю. Находится темная материя, по всей видимости, в предложенных нами дырках физического континуума. И энергии в этих дырках физического пространственновременного континуума намного больше известной нам сегодня энергии Вселенной. И пространственно-временной континуум можно назвать континуумом бытия-небытия.

В заключение, дабы не обижать самолюбие «беотийцев» шокирующими их сознание результатами настоящего сообщения, приведем небольшой отрывочек из И.Пригожина. «В своих «Темах» Мерло-Понти утверждал, что «философские» открытия естествознания, концептуальные преобразования его основ нередко происходят в результате негативных открытий, служащих толчком к пересмотру сложившихся взглядов и отправным пунктом для перехода к противоположной точке зрения. Доказательства невозможности или несуществования (будь то в теории относительности, квантовой механике или термодинамике), показали, что природу невозможно описать «извне», с позиций зрителя. Описание природы - живой диалог, коммуникация, и она подчинена ограничениям, свидетельствующим о том, что мы - макроскопические существа, погруженные в реальный физический мир» [8].

\section{В Ы В О Д Ы}

1. Вещи, не имеющие пространственного, геометрического размера, т.е. если их пространственный размер равен нулю, друг друга касаться не могут дистинктивно. Это значит, что понятие непрерывности исчезает, превращаясь в конструкт или концепт без референта, и если считать, что линии существуют, то непрерывных линий без разрывов быть не может. То же можно сказать и о плоскостях: если считать, что плоскость существует, то любая плоскость, у которой толщина равна нулю, должна быть равномерно дырявой. Пространство тоже дырявое, т.е. прерывистое, а не непрерывное. Поэтому, базовыми единицами в нашей теории являются: 1) точка (как и у Евклида); 2) дырка; 3) отточие (у Евклида - прямая); 4) сетка (у Евклида - плоскость).

2. Первый парадокс точек: считается, что сплошная (гладкая, непрерывная) линия существует, и она состоит из соприкасающихся точек, но сплошная линия не существует, т.к. это не сплошная непрерывная линия, а что-то вроде пунктира, т.е. нечто разорванное и с дырками. Т.е. считалось, что точки соприкасались, и поэтому образовывалась линия. Но они соприкасаться не могут, и поэтому сплошная линия образоваться не может. 
3. Второй парадокс точек: на числовой оси или на любой линии геометрический размер промежутков между безразмерными точками должен быть равен размеру точки, но размер промежутков не может быть равен размеру точки.

4. Третий парадокс точек: до сих пор считалось, что $\pi$ больше 3 , но меньше 4. Но мы установили, что $\boldsymbol{\pi}$ нельзя сравнивать ни с 3 , ни с 4, потому, что это разнородные, разнокачественные вещи, и поэтому $\pi$ и не больше 3 , и не меньше 4, и не меньше 3 , и не больше 4, и не равно 3, и не равно 4. Но в математике «не больше» - это то же, что и «меньше или равно», т.е. $\leq$, а «не меньше» - это то же, что и «больше или равно», т.е. $\geq$. Поэтому можно написать, что $3 \geq \boldsymbol{\pi} \geq 4$ ? Таким образом, с одной стороны принято, что, $\boldsymbol{\pi}$ больше 3 и меньше 4, и потому можно написать $3<\pi<4$, но, с другой стороны, получается, что $3 \geq \boldsymbol{\pi} \geq 4$ ? Можно также показать, что $\boldsymbol{\pi}=3$ и $\boldsymbol{\pi}=4$. Такие противоречия получились изза того, что мы попытались сравнивать несравнимые вещи, а именно трансцендентное «число» $\boldsymbol{\pi}$ с нетрансцендентными (натуральными) числами 3 и 4, что и привело к этому парадоксу. Для несравнимых вещей знаки сравнения больше $(>)$, меньше $(<)$, не больше $(\leq)$ или не меньше $(\geq)$ не применимы и не имеют смысла, т.к. несравнимые вещи сравнивать нельзя. Таким образом, установлено, и поэтому необходимо понять, что количественный критерий натурального ряда не применим к трансцендентным числам. Т.е. свойства бытия нельзя применять к небытию. И вообще, думаем, бытие нельзя сравнивать с небытием. Правда, хотя великий Гегель и утверждал, что бытие и небытие - это одно и то же [9], но думаем, в нашем случае это не так. Поэтому $\boldsymbol{\pi}$ нельзя сравнивать ни с 3 , ни с 4 , ни с другими натуральными числами. Натуральные и вообще, рациональные числа - это бытие, а трансцендентные числа - это небытие. Т.е. для $\boldsymbol{\pi}$ обычно берут значение 3,14 , но необходимо понять, что $\boldsymbol{\pi}$ - это не 3,14 и даже не число приблизительно равное 3,14 , а совсем другая вещь в философском смысле. Т.е. трансцендентные «числа» - такая же химера, как и квадратный корень из арбуза, логарифм треугольника или компас в четвертой степени. Т.е. трансцендентное «число» - это условное обозначение чего-то несуществующего, вернее феноменологического. И для $\boldsymbol{\pi}$ места на принятой числовой прямой нет. Но если $\boldsymbol{\pi}$ силком загнать в принятую сегодня числовую ось, то это «число» окажется в дырке. Возможно, прав был Л.Кронекер, утверждая, что бог создал натуральные числа; все остальное - дело рук человека.

Еще раз объясним популярно, почему так получается. Дело в том, что обычно у референтов бывает много предикатов, свойств и параметров. Так, если взять телевизор и ведро, то увидим, что и у телевизора, и у ведра есть много схожих параметров, например, масса, площадь поверхности, объем, цвет и др. Поэтому их можно сравнивать по какому-то отдельному параметру, например, массе. Т.е., несмотря на то, что телевизор и ведро разнокачественные вещи в философском смысле, все равно, их можно сравнивать по какомуто одному свойству, присущему им обоим. В случае чисел это не так. Дело в том, что у чисел есть только одно свойство - это свойство выражать количество. Но, как было показано выше, многие из так называемых чисел на самом деле числами не являются, т.е., например, натуральные числа и иррациональные «числа» разнокачественные вещи. И учитывая, что у чисел вообще-то есть только одно свойство - выражать количество, и этим свойством 
обладают только рациональные числа, а иррациональные «числа» и, в частности, трансцендентные «числа», таким свойством, в общем-то, не обладают, то эти числа нельзя сравнивать. Т.е. трансцендентные числа референтом не обладают. И $\boldsymbol{\pi}$ такая же химера, как и черт, но мы же слово черт используем, хотя такого референта нет. Так же и рациональные числа, например, 3 и 4, совершенно отличаются от «числа» $\pi$, т.е. это разнокачественные вещи. И учитывая то, что у любых чисел других свойств, кроме как выражать количество, нет, приходим к выводу, что их сравнивать нельзя. Поэтому и получилось, что $\pi$ и не больше 3, и не меньше 4 (!?).

5. Четвертый парадокс точек: до сих пор думали, что поверхность и, в частности, плоскость, существует. Но плоскость не существует, т.к. это не поверхность, а нечто дырявое, т.е. что-то вроде сетки. Т.е. поверхность - это нечто дырявое, вроде дуршлага.

6. Между любыми двумя рациональными числами на общепринятой сегодня (но неправильной) числовой оси, находится хотя бы одно иррациональное «число», которое туда втиснуто необоснованно. Это необоснованное расположение иррациональных чисел на оси рациональных чисел аналогично тому, что на оси скоростей расположили массу или напряжение. Т.е. для каждой физической величины требуется (и поэтому необходимо) ввести отдельную ось.

7. Рациональные и иррациональные числа в философском смысле (не математическом!) являются противоположными, и эти два вида чисел различны качественно, и поэтому они несравнимы. Для них требуются две различные числовые оси.

8. Минимальная в пространственном отношении (по размеру) вещь в мире - или точка континуума, или его дырка. Т.е. существует квант длины. А дырка - это место, свободное от точки, т.е. «материала» континуума.

9. Длина окружности несоразмерна с ее диаметром потому, что и окружность, и диаметр (отрезок) - дырявые. Если увеличить длину окружности на одну дырку - его диаметр увеличится на один квант длины, и все равно, они останутся несоразмерными (несоизмеримыми). И если окружность разрезать в одном месте и выпрямить, то если до сих пор думали, что длина получившегося отрезка окажется равной длине этой окружности, то на самом деле, длина получившегося отрезка окажется меньше длины той окружности на один квант длины. И если разделить длину этого получившегося отрезка на диаметр той окружности, то трансцендентность исчезнет!? И если увеличить длину окружности на один квант длины, то диаметр увеличиться не сможет!?

10. Физический континуум, введенный по аналогии с математическим континуумом, и изначально считавшийся континуальным, т.е. непрерывным (сплошным), на самом деле является прерывистым, т.е. с дырками. Взаимодействие дырок физического континуума с его точками (т.е. архефолия или взаимодействие бытия и небытия) есть и начало, и основа, и основание философского движения.

11. Установленный недавно физиками теоретический феномен кротовой норы, через которую возможно перемещение из одной галактики в другую, по всей видимости, может осуществляться именно через дырки физического континуума, т.е. через небытие, причем со скоростью намного превышающей скорость света в вакууме. И так называемые 
элементарные частицы, например, протоны, нейтроны - тоже дырявые (пористые). Пространство тоже дырявое (пористое). Если предположить, что Большой взрыв действительно имел место, то он потому и произошел, что та первичная точка была пористая, и именно взаимодействие ее дырок с ее точками и привело к взрыву. Кстати, Большой взрыв, возможно, произошел не в одной точке, а в нескольких, и это был разрыв вакуума. Возможно вся масса Вселенной не была в одной точке, а возможно, этой точки не было вообще, т.к. если все образовалось из точки, то вокруг этой точки должно было быть гравитационное поле, а это значит, что было пространство, где это поле было. А это противоречит всей теории Большого взрыва. Таким образом, можно считать, что к движению (взрыву) привело взаимодействие бытия с небытием (т.е. архефолия).

12. Большая часть энергии и информации Вселенной скрыта в дырках пространственно-временного континуума. В них же скрыта от нас и темная материя. Поэтому, и общую, и специальную теорию относительности пора пересматривать. Точно также, причиной дуализма корпускула-волна, т.е. того, что микрочастица является одновременно и волной, и частицей, а также дуализма бытия-небытия и дуализма бифуркаций-фракталов является несплошность континуума и архефолия. Т.е., наличие дырок в физическом континууме является причиной дуализмов бытия-небытия, волнычастицы, бифуркации-фрактала, ничто-нечто ...

13. Предложенная нами теория и новая система и мироздания, и науки, дает также философское объяснение того, почему давно известные так называемые комплексные числа нельзя сравнивать друг с другом, т.е. нельзя спрашивать, какое из них больше, а какое меньше. Стало понятно, почему. Потому, что они разные не количественно, а качественно. Т.е. каждое комплексное «число» отличается и от других комплексных «чисел», и чисел вообще, качественно. Все они совершенно разные вещи в философском смысле, потому и не сравнимые. Т.е. любые качественно разные вещи - несравнимые, а любые несравнимые вещи - качественно разные.

14. $\quad$ У точки размер равен нулю, у дырки же размер больше нуля и есть границы. А вообще-то, если ширина вещи равна нулю, то длины у нее быть не может?

15. Пеано, сам того не подозревая, интуитивно пришел к своим пяти аксиомам конструктивного построения натурального ряда. Сам Пеано этого не знал, но в этих аксиомах совершенно незаметно, в скрытой форме выражена мысль, что, например, 5 может быть больше 3 только в том случае, если между 3 и 5 есть еще что-то. Вот это «что-то» и есть то связующее трех и пяти. Например, в данном примере это - число 4. И благодаря именно этому числу возникает и происходит философское отношение R. Вот это отношение и способствует передаче информации.

16. И материальная линия, и материальная плоскость, тоже несплошные - они прерывистые и состоят из материальных точек и дырок. Траектории элементарных частиц тоже должны быть прерывистыми?

17. В предлагаемой системе понятие непрерывной функции исчезает. Это происходит потому, что непрерывного аргумента $\boldsymbol{x}$ не бывает ( $\boldsymbol{x}$ всегда прерывистый). Т.е. если линия действительно существует, то она прерывистая (т.е. это - отточие); если 
плоскость действительно существует, то она дырявая. Если же их (т.е. линий и плоскостей) нет, т.е. они - только воображаемые, то все равно, они дырявые, в любом случае. Не существует такое трансцендентное «число», которое при возведении в какую-либо степень давало бы другое трансцендентное число. Да и точного значения трансцендентного числа тоже нет.

18. Если между физическими телами или философскими вещами нет ничего материального, то расстояния между ними не существует. Расстояние возможно только в том случае, если промежуток между этими вещами заполнен чем-то материальным или бытием. Если линия нулевой ширины сплошная, то она обладать длиной не может!? Длина возникнет только в случае, если линия прерывистая, т.е. если между точками наличествуют дырки!? Философская ошибка Евклида в том и заключается, что длины без ширины не бывает. Если ширины нет, то это - небытие. А небытие, наверное, не имеет длины. Поэтому расстояние между точками быть может, а длины между точками быть не может. Элементарные частицы могут обладать размером (диаметром) только в случае, если они несплошные (дырявые). Принятое в теории относительности релятивистское сжатие оказывается возможным благодаря наличию промежутков между точками всего сущего. Уменьшение расстояния между точками и приводит к сжатию. Вселенная потому и смогла в свое время сжаться до точки, которая затем взорвалась (Большой взрыв), что двигалась со скоростью света и состояла из пустот, дырок (если, конечно же, продолжать предполагать, что теория относительности - теория правильная). Т.е. Большой взрыв произошел из-за взаимодействия точек с дырками этой первой начальной «точки». Если Вселенная снова сожмется в «точку», то она все равно взорвется.

19. Если продолжать использовать привычную и принятую сегодня систему математики, т.е. то, что за точку пересечения осей координат выбран ноль, то в дырках находятся трансцендентные «числа». Если же выбрать оси координат непривычно странным образом, например, за начало координат выбрать не ноль, а, скажем, число $\boldsymbol{\pi}$ (трансцендентное «число»), то в дырках окажутся рациональные числа. Всего же вариантов расположения осей $\boldsymbol{x}$ и $\boldsymbol{y}$ по отношению к друг другу, а стало быть, пересечения всех прямых и линий вообще, четыре: 1) ось $\boldsymbol{y}$ проходит через точку на оси $\boldsymbol{x}$ и точка оси $\boldsymbol{y}$ совпадает с точкой оси $\boldsymbol{x} ; 2$ ) ось $\boldsymbol{y}$ проходит через дырку в оси $\boldsymbol{x}$ и точка оси $\boldsymbol{y}$ расположена в дырке оси $\boldsymbol{x} ; 3)$ ось $\boldsymbol{y}$ проходит через ось $\boldsymbol{x}$ так, что дырка в оси $\boldsymbol{x}$ совпадает с дыркой в оси $\boldsymbol{y}$; 4) ось $\boldsymbol{y}$ проходит через ось $\boldsymbol{x}$ так, что точка на оси $\boldsymbol{x}$ оказывается в дырке оси $\boldsymbol{y}$. Из наших философских рассуждений выше получилось, что на точках расположены рациональные числа, а в дырках иррациональные «числа» и трансцендентные «числа». Но для нормальных чисел места в дырках нет. Поэтому мы должны исключить варианты 2 и 4 как невозможные. Значит, реально может быть лишь два варианта 1 и 3.

\section{References}

1. Laue M. Istoriia fiziki. [History of Physics] M., gos. izd. tekh.-teor. literatury, 1956, p. 5. 
2. Vezirov H.N., Vezirov-Kengerli F.H. Problemy filosofskoi $i$ sotsiologicheskoi kategorii aktual'nosti [Problems of the philosophical and sociological category of relevance]. Zhurnal «Nauchnye trudy» Instituta filosofii NANA, №2, 2018, pp. 29 - 48.

3. E.Bekkenbakh, R.Bellman. Vvedenie v neravenstva [Introduction to inequalities]. M.: Mir, 1965, p.7.

4. Vezirov H.N., Vezirov-Kengerli F.H. Nekotorye problemy postsovetskikh respublik [Some problems of the post-Soviet republics]. Baku, "Ecoprint», 2018, $234 \mathrm{~s}$.

5. Evklid. Nachala [Beginnings]. T.1, M.-L., Giz.TTL, 1950, p. 11.

6. Pogorelov A.V. Geometriia. Uchebnik dlia 7-11 klassov obshcheobrazovatel'nykh uchrezhdenii [Geometry. Textbook for 7 - 11 grades of educational institutions]. M., «Prosveshchenie», 1998, pp. $6,65,74$.

7. Prigogine I., Stengers I. Poriadok iz khaosa [Order out of chaos]. M., «Progress», 1986, p. 371

8. Hegel G.W.F. Nauka logiki [Science of logic]. V.1, M., «Mysl'», 1970, p.140.

Translation of the Title, and References to the Author's Language

ФИЛОСОФСКО-МАТЕМАТИЧЕСКИЙ ПАРАДОКС ТОЧЕК

Хикмет Ниязи оглу Везиров, доктор физ.-мат. наук, руководитель лаборатории Института физики НАНА,

\section{Фикрет Хикмет оглу Везиров-Кенгерли}

E-mail: vezirov55@mail.ru

\section{Л И Т Е Р А Т У Р А}

1. М.Лауэ. История физики. М., гос. изд. тех.-теор. литературы, 1956, с. 5.

2. Х.Н.Везиров, Ф.Х.Везиров-Кенгерли. Проблемы философской и социологической категории актуальности. Журнал «Научные труды» Института философии НАНА, №2, 2018, c. $29-48$.

3. Э.Беккенбах, Р.Беллман. Введение в неравенства. М.: Мир, 1965, с.7.

4. Х.Н.Везиров, Ф.Х.Везиров-Кенгерли. Некоторые проблемы постсоветских республик. Баку, "Ecoprint», 2018, 234 c.

5. Евклид. Начала. Т.1, М.-Л., Гиз.ТТЛ, 1950, с. 11.

6. А.В.Погорелов. Геометрия. Учебник для 7 - 11 классов общеобразовательных учреждений. М., «Просвещение», 1998, с.с. 6, 65, 74.

7. И.Пригожин, И. Стенгерс. Порядок из хаоса. М., «Прогресс», 1986, с. 371.

8. Г.В.Ф.Гегель. Наука логики. Т.1, М., «Мысль», 1970, с.140. 


\title{
Creating a Developmentally Appropriate Learning Environment in Preschool Education Institutions
}

\author{
Reipolska Olga \\ ORSID ID 0000-0002-5524-7110 \\ PhD in Pedagogy, Associate Professor \\ Institute of Problems on Education \\ of the National Academy of Educational Sciences of Ukraine (Kyiv, Ukraine) \\ Lutsenko Victoriia \\ ORSID ID 0000-0002-1681-0601 \\ Research Officer \\ Institute of Problems on Education \\ of the National Academy of Educational Sciences of Ukraine (Kyiv, Ukraine)
}

\begin{abstract}
The article is devoted to the problem of modernization of preschool education in the conditions of modern educational reforms related to realization of humanistic paradigm. The authors describe the creating of developmental educational environment in establishments of preschool education.

The article presents the theoretical substantiation and some technological statements of designing the educational environment as a factor in the development of the personality of a preschool child, in particular, theoretical and methodological principles of designing the educational environment of preschool education, namely: principles (pedagogical expediency, integrity, individualization, cognitive activity and independence), basic scientific approaches (systemic, synergetic, environmental, personality-oriented, activity-communicative), objective laws.

The authors found that the theoretical interpretation of the concept the preschool child's personality development is based on the scientific position on its integrity and ability to make qualitative changes in the process of their own activities and communication with other people. It is determined that the development of the child's personality directly depends on the quality of content and procedural organization of the environment in which he is brought up.

Key words: educational environment, developmentally appropriate learning environment, preschool education institutions, personal development, preschool child.
\end{abstract}

Relevance of the research. Modernization processes have caused significant changes in the domestic preschool education system. The implementation of the humanistic paradigm actualized the concept of an educational environment, which was little in demand in previous times because in fact it was almost replaced by the concept of the educational process.

The problem of creating a developmental environment and organization of educational work in it is due to the fact that the vast majority of teachers, unfortunately, reduces the concept of "educational environment" to the subject-spatial organization of furniture, equipment, 
teaching aids in the group, ignoring other aspects of this phenomenon, in particular, the possibility of personal self-determination of the preschooler in various activities, despite the imposition on him of activities organized at the initiative of the teacher.

The purpose of the research is to present the results of the ascertaining stage of the pedagogical experiment on the creation of a developmental educational environment for the individual development of the child.

Review of previous studies. The theoretical basis of the problem of creating an educational environment in the school as a means of personal development of children of early and preschool age is the scientific achievements of scientists, performed within the issues of the philosophical and sociological concept of personality culture (Kagan [5]); psychological theory of personality (Leontiev [11]; Rubinstein [17]); personality development in preschool age (Artemova [1], Elkonin [20], Kononko [9], Ladivir [19], Pirozhenko [15]; personalityoriented approaches to personality development (Bekh [2], Yakymenska [21]; modernization of the preschool education system (Gavrish [4], Kononko [9], Ponimanska [16], etc.); transformation of the educational space of the preschool institution (Kononko [9], Krutiy [4], Matviienko O. [22; 23], Pet'ko [12; 13; 14], and others).

Findings and discussions. Research work is carried out on the basis of preschool institutions of Ukraine in 5 regions: Kyiv, Donetsk, Rivne, Khmelnytsky, and Chernivtsi. The program of research work provided for the study of the features of the educational environment created by teachers and the forms of organization of educational work with children in it.

During the research, educators of early age groups and preschool groups recorded and sent in the form of photographs, videos, descriptions of the structural and semantic content of the educational environment of groups, accompanied by comments explaining their vision and understanding of each of its elements. In addition, the method of monitoring the independent activities of children in their free time was used. The analysis of the collected information material made it possible to systematize the idea of the state of the subject-content content of the educational environment and the state of individual and differentiated educational work in it.

Generalization of various approaches to the definition allows us to conclude that the developmental educational environment of a modern educational institution - a set of spiritual and material conditions of the educational institution, ensuring self-development of free and 
active personality, the realization of the creative potential of the child. The developmental educational environment is a functional and spatial association of subjects of education, between which close diverse relationships are established, and can be considered as a model of socio-cultural space, where the formation of personality takes place.

The organization of the educational development environment is defined as the provision of a set of conditions related to the logistical and software-methodological support of the educational process; creation of conditions of creative comfortable interaction of children among themselves, with teachers, parents; using various methods and means of activating activities that ensure the creative development of the individual, etc. $[6 ; 7 ; 12 ; 13$; $14 ; 18 ; 21 ; 22]$.

Under the developmental educational environment we understand specially modeled conditions (natural, subject and social) in which the child grows, masters the science of life, becomes a competent person with its own individual characteristics. Creating an educational environment allows the child to realize their own potential, take the initiative and fully realize themselves.

The main idea of the study is to understand the relationship between the development of the personality of a preschool child and the developmental educational environment organized by teachers in a preschool institution conducive to child development.

Theoretical analysis of philosophical, psychological, pedagogical literature allowed to determine the essence of the conceptual phrase "designing the educational environment" as a specially organized pedagogical activity, which consists in building and implementing a system of scientific guidelines that set the technological vector of interaction of all participants (subjects). aimed at the holistic development of the child's personality.

During the implementation of the ascertaining stage of the pedagogical experiment, our attention was focused on: identifying the level of understanding by teachers of the conceptual field of research; content and procedural content of the educational environment in the groups of early age and preschool groups of basic PEI (preschool education institutions); features of organized by adults and independent activities of children in the educational environment of groups.

It was found that at the beginning of the study, most teachers $(67,8 \%$ of respondents) have somewhat misguided, outdated ideas about the nature, functions and structure of the 
educational environment. Thus, the educational environment is considered by them as a closed social construct, which should be dominated by the subject-object interaction of the teacher with the child, as a result, preference is given to authoritarian ways of interacting with children in the model "top-down", and personality development is seen as one-sided learning process, transfer of knowledge-skills-abilities available to the child by the teacher.

The share of progressive educators (32,2\% of respondents) have a positive attitude to the idea of free self-determination of children in the subject-spatial environment of the group (which significantly narrows the essence of the concept), but only 5,7\% have the opportunity to do so. The presence of the so-called "network of classes", according to $48,7 \%$ of respondents, does not leave time for active and proactive activities of children in the group. In addition, most of the educators surveyed ( $74 \%$ ) even outside the classroom try to organize children around them, minimize free space for independent activity, fearing to lose control over children ("If I let them (children), how can I collect", "I then I will not be able to see / control everyone" - typical answers of teachers).

The analysis of the obtained data convincingly shows that the educational environment is not considered (67\%) and is not used (87\% of respondents) as a factor in the development of the child's personality. Neither educators nor the management of experimental children have a clear idea of the place and facilitation role of the teacher in stimulating different types of children's activity, to some extent they are afraid of it, because they have no experience of competent psychological and pedagogical support of children's personal development.

Note that nominatively in the vast majority of groups of both early and preschool age (87\%) for the development of developmental centers and active activities of children in them: play, sensory, book, art center, intellectual, physical development, theater, and so on. The $46 \%$ of groups are dominated by modern play and didactic equipment, but $54 \%$ have a filling of educational centers that do not meet the age, needs and interests of modern children. A special problem is the lack of sufficient space and overcrowding of groups, which does not allow children to develop activities of their choice, they do not have the opportunity to be alone or self-determined with the type or method of their own activities (53\% of respondents noted this).

Problematic, in our opinion, is the fact that the leadership of most PEI does not consider the educational activities of teachers outside the classroom, in an individual format, as 
valuable, important, and therefore requires teachers to constantly orient children on their own, their constant association for group, orderly activities in which, in their opinion, the activities of the educator is obvious. The uniformity of the general group form of organization of children for moving play, observation, reading, explanation, etc. does not take into account the interest and desire of a particular child. Therefore, the vast majority of children perceive the explanations, demonstrations, actions of the educator without enthusiasm, at the first opportunity try to get away, do not hold attention. That is, the result of such educational work is minimal.

The survey of educators showed that in $95 \%$ of cases teachers are not ready to implement the principle of individualization and differentiation of educational activities in the developmental environment of the group. They are lost in the development of tasks for individual work, can not determine the real level of complexity required by a particular child, because methodically competent to observe the actions of children, reflect and reflect, unfortunately, are not trained.

Thus, the results of the observational experiment, their analysis and reflection served as a platform for determining favorable psychological and pedagogical conditions for personal development of preschool children in the educational environment of preschool education and development of experimental methods of relevant educational work on the basis of individualization and differentiation.

The development of the environmental model was based on the idea of a holistic approach to organizing their lives in preschool education, updating the content, forms and methods of educational activities, creating a developmental environment that will promote the use of personality-oriented technology in early ontogenesis of socially approved patterns of behavior (Manuilov, 2008).

The implementation of the concept was aimed at enriching preschoolers' ideas about their own virtues and flaws; fostering in them self-esteem, the ability to trust their own abilities; formation of the ability to behave independently, to act constructively, to defend one's own dignity in one's actions and deeds, to substantiate one's own opinion, to focus on basic moral values. An important direction was to ensure the balance of self-physical, self-spiritual and self-social available to preschoolers, optimization of the model of interaction in the systems 
"adult-child" and "child-child"; creation of appropriate theoretical and methodological and software.

Let's briefly reveal our own understanding of the main positions of building an educational environment on the declared values set out above.

In the educational process there is a correlation of three main models of interaction between teacher and children: "learning by example" (educator dominates over children), "joint activities" (parity) and "independent activities of children" (activities that occur at the initiative of children), and in favor of the first model.

To the block "We teach by example" we include all situations when the educator dominates (shows the initiative, proclaims, informs, directs actions of children, organizing them). With the dominance of the first model, it is obvious how important for the teacher what he plans, he says, he will do himself, and how insignificant time is for the child's own initiatives. In situations of the second model "Joint activity" (joint play, communication, research, work), the adult also tries to maintain a dominant position. However, scientists have long proven that the child develops best in activities in which he takes an active position, and not just a listener and performer; that she will assimilate the information she aspired to most fully and qualitatively, and not the information that should be according to the plan. As for the third model, independent does not mean thoughtless, aimless activity of children, it is an activity in which the child, showing interest in what he is doing, makes his own efforts to realize his plans.

Changing the ratio of these models in favor of the dominance of independent activity is the main condition for shifting the emphasis to educational work in the developmental educational environment. This in no way means abandoning the classroom as a form of learning, it must acquire modern characteristics corresponding to the declared humanistic idea.

When planning educational work in the educational environment, we should focus not so much on the knowledge component, but on the child's mastery of the main types of children's activities - play, speech, communication, sensory-cognitive, artistic-aesthetic, household, health. There can be several options. First: abandon daily planning; reorient to drawing up a plan for the week; to determine in the weekly planning a specific goal-result - "after living with children... they will be able to". The second option - planning educational work by type of activity, taking into account the three blocks identified by us: what new knowledge and 
skills I want to teach children; in what knowledge-skills to exercise by means of joint activity; favorable conditions must be created for mastering any independent actions. The third option: to the traditional way of planning to add a block of tasks focused on their implementation in terms of independent activity.

Group-wide integrated classes should be held daily. However, in the daily life of children, we must free up time for independent activities in a thoroughly prepared, filled with the necessary materials environment. When we talk about independent activities, we mean free play of children and independent cognitive, artistic, physical activity in a group or on the playground. In order for children's activities to be useful and interesting for them, the educator should fill the environment with the materials necessary for independent activity and place the centers in a group room so that children do not interfere with each other.

During independent activities for all or most children, the educator can conduct individual (from one to 3-4 children) educational work, keeping all other children in sight. Expanding the limits of freedom for children - the teacher must agree with the children on the rules and strictly follow them. There should be a limited number of rules, for example 2-4. They should be formulated concisely and be sure to choose a symbolic symbol or signal word for each child. Another issue concerns the self-organization of children. Today, there are many different proven ways to help children organize themselves in a group environment for independent activity. Thus, the use of a socio-game method (by the color of ribbons, rubber bands, the size of buttons, etc.) helps children to determine by lot what activities they want to do. The time management screen works successfully for this purpose in separate kindergartens.

The smallest but very important unit of organization of educational work in the developmental environment of the group is the task. It is with the help of tasks that the educator can direct the independent cognitive or artistic activities of children. In order to perform the task correctly, the child must understand what he has to do. It is necessary to develop tasks for children so that each corresponds to a specific educational task, has clear and understandable for the child criteria for the quality of its implementation. Given the different levels of preparation and development of children, the tasks should be differentiated by complexity, have a reproductive (do exactly as in the picture) or creative nature of the performance (consider how you could do it). 
Tasks should be offered to children in a planned way, with a gradual complication of the content, so that it can be provided through their implementation of the educational program. Each of the children in the group must complete the required tasks during the day or week. If the task did not work out the first time, the child should be able to practice to achieve the desired result. In addition to the required ones, the educator should prepare a sufficient number of other tasks that the children will perform in their free time. Children can celebrate their achievements (I have learned, I already know how to...) on a special ribbon of achievements and desires. The child sets a task to learn something "I want", and then notes that now she has learned "I can". It helps children develop such important skills as goal setting and develop an equally important quality as focus.

Conclusions. The article presents the theoretical justification and some technological statements of designing the educational environment as a factor in the development of the personality of a preschool child, in particular, theoretical and methodological principles of designing the educational environment of preschool education, namely: principles (pedagogical expediency, integrity, individualization, cognitive activity and independence), basic scientific approaches (systemic, synergetic, environmental, personality-oriented, activity-communicative), objective laws. It is established that the basis of the theoretical interpretation of the concept of personality development of a preschool child is the scientific position on its integrity and ability to make qualitative changes in the process of their own activities and communication with other people. It is determined that the development of the child's personality directly depends on the quality of content and procedural organization of the environment in which he is brought up.

The research continues, further publications will cover the criteria and indicators, types of individual personal development of older preschool children, reveal the conditions of

designing an educational environment for individual personal development of early and preschool children, characterize the model of designing an educational environment.

\section{References}

1. Artemova L. Realiyi ta perspektivi rozvitku doshkIlnoYi osvIti Ukrayini v kontekstI klyuchovih pozitsIy Bolonskoyi deklaratsiyi [Realities and prospects of preschool education development in Ukraine in the context of key positions of the Bologna Declaration]. Visnik GluhIvskogo derzhavnogo natsIonalnogo pedagogIchnogo universitetu im. O. Dovzhenka. 2010. Vol 16. Pp. 10-14. 
2. Bekh I. D. Osobystist u konteksti oriientyriv rozvyvalnoho vykhovannia [Personality in the context of guidelines for developmental education]. Innovatyka u vykhovanni. 2015. URI : http://nbuv.gov.ua/UJRN/inuv2015_1_4

3. Vyhotskyi L. S. Psykholohyia razvytyia cheloveka [Human developmental psychology]. Moskva : Smysl; Eksmo, 2005.

4. Gavrish N., Krutiy K. Seredovischna model-panatseya? Lamaemo stereotipi [Is the environmental model a panacea? We break stereotypes.]. DoshkIlne vihovannya. 2019. No 4. Pp. 4-11.

5. Kagan M. Sistemnyiy podhod $i$ gumanitarnoe znanie [Systems approach and humanitarian knowledge] : Izbr.st. M.S.Kagana. Leningrad: izd-vo LGU, 1991.

6. Kanishevska L. V. Krokuiemo do sotsialnoi zrilosti [Stepping towards social maturity] : nauk.-metod. posib. Kyiv: In-t problem vykhovannia NAPN Ukrainy, 2011. 175 p.

7. Kanishevska L. V., Vyshnivska N. V. Pedahohichni umovy vykhovannia humannosti $v$ uchniv molodshoho shkilnoho viku $v$ pozaurochnii diialnosti shkilinternativ [Pedagogical conditions of primary school students' humanity education in extracurricular activities at boarding schools] // Topical issues of pedagogy: Collective monograph. - Edizioni Magi, Roma, Italy, 2019. 228 p.

8. Kanishevska L. V., Sukhopara L. V. Formuvannia tolerantnosti $v$ molodshykh shkoliariv u pozaurochnii diialnosti: teoriia i praktyka [Formation of tolerance in preschool students in extracurricular activities: theory and practice] : monohrafiia. Kyiv : Komprynt, 2017. $405 \mathrm{p}$.

9. Kononko O. L. Psykholohichni osnovy osobystisnoho stanovlennia doshkilnyka (systemnyi pidkhid) [Psychological bases of personal formation of the preschooler (system approach)]. Kyiv : Stylos, 2000.

10. Krutiy K. Osvitniy prostir doshkilnogo navchalnogo zakladu [Educational space of a preschool educational institution]: monografiya: u 2-h ch. Kyiv : OsvIta, 2009.

11. Leontev O. M. Deiatelnost, soznanye, lychnost [Activity, consciousness, personality.]. Moskva : Nauka, 1975.

12. Petko L. V. Derzhavnyi standart pochatkovoi osvity u rakursi formuvannia sotsialnoi aktyvnosti dytyny [State standard of primary education in the perspective of the formation of social activity of the child]. Naukovi zapysky Berdianskoho derzhavnoho pedahohichnoho un-tu. Seriia : Pedahohika : zb. nauk. prats. Berdiansk : BDPU, 2018. Vol. 1. Pp. 92-97.

13. Pet'ko L. V. Osobystist. Socium. Navchal'ne Seredovyshhe [Personality. Socium. Teaching Environment]. Gumanitarnyj visnyk DVNZ «Perejaslav-Hmel'nyc'kyj derzhavnyj pedagogichnyj universytet imeni Grygorija Skovorody»: zbirnyk naukovyh prac. 2014. Vol. 35. Pp. 102-110.

14. Pet'ko L. V. Pidgotovka majbutnih pedagogiv-vyhovateliv do navchannja inozemnoi movy ditej $v$ doshkilnyh osvitnih zakladah [The ways of a process of preparation of future tutors in foreign language teaching of preschool children] / Visnyk Instytutu rozvytku 
dytyny. Vol. 23. Serija: Filosofija, pedagogika, psyhologija: Zbirnyk naukovyh prac. Kyiv : Vyd-vo NPU imeni M.P.Dragomanova, 2012. Pp. 111-115.

15. Pirozhenko T. O. Ihrova diialnist doshkilnyka : navchalno-metodychnyi posibnyk [Preschool play activities]. Kyiv : Heneza, 2013.

16. Ponimanska T. Gotovnist do pedagogichnih innovatsiy u konteksti gumanistichnoyi pedagogiki [Readiness for pedagogical innovations in the context of humanistic pedagogy]. Onovlennya zmistu i metodiv doshkilnoyi osviti v Ukrayini. 1999. Vol. 5. Rivne : RDPI. Pp. 10-15.

17. Rubynshtein S. L. Osnovi obshchei psykholohyy [Fundamentals of general psychology] : v 2-kh t. Moskva : Pedahohyka, 1989.

18. Sliusarenko N., Kulbatska M. Subiekt-subiektnyi pidkhid do orhanizatsii pedahohichnoho protsesu [Subject-subject approach to the organization of the pedagogical process]. Liudynoznavchi studii. Pedahohika. 2015. No 1 (33). Pp. 194-201.

19. Stanovlennia vnutrishnoi kartyny svitu doshkilnyka [Formation of the internal picture of the preschooler's world] : monohrafiia. Kirovohrad : Imeks-LTD, 2012. URI : http://lib.iitta.gov.ua/1604/ 1960.

20. Elkonyn D. B. Detskaia psykholohyia [Child psychology]. Moskva : Pedahohyka,

21. Yakimanskaya I. Razrabotka tehnologii lichnostno orientirovannogo obucheniya [Development of technology for student-centered learning]. Voprosyi psihologii. 1995. No 2. Pp. 37-38.

22. Matviienko O. Pedagogy of partnership in the process of setting new Ukrainian school // Challenges and opportunities of scientific thought development: collection of scientific articles. - GPG Publishing Group, Pretoria, South Africa, 2017. P. 151-156.

23. Matviienko Olena. Theoretical Basics of Preparation of Teachers to Pedagogical Interaction with Children of Various Age. Intellectual Archive. 2014. Volume 5. No. 5 (September). - Toronto : Shiny Word Corp., Canada. Pp. 105-117.

\section{Translation of the Title, Abstract and References to the Author's Language}

\section{УДК 373.2}

Рейпольська Ольга, Луценко Вікторія. Створюємо розвивальне освітнє середовище у закладах дошкільної освіти.

Стаття присвячена проблемі модернізації дошкільної освіти в умовах сучасних освітніх реформ, пов’язаних із реалізацією гуманістичної парадигми. Це й актуалізувало необхідність створення розвивального освітнього середовища в закладах дошкільної освіти.

У статті представлено теоретичне обгрунтування та окремі технологічні виклади проектування освітнього середовища як чинника розвитку особистості дитини дошкільного віку, зокрема, теоретико-методологічних засад проектування освітнього середовища закладу дошкільної освіти, а саме: принципи (педагогічної доцільності, цілісності, індивідуалізації, пізнавальної активності та самостійності особистості), основні наукові підходи (системний, синергетичний, середовищний, особистісно- 
зорієнтований, діяльнісно-комунікативний), об'єктивні закономірності. Авторами встановлено, що в основі теоретичного тлумачення поняття розвитку особистості дитини дошкільного віку лежить наукове положення щодо ії цілісності й здатності до якісних змін у процесі власної діяльності і спілкування з іншими людьми. Визначено, що розвиток особистості дитини безпосередньо залежить від якості змісту й процесуальної організації середовища, в якому вона виховується.

Ключові слова: освітнє середовище, розвивальне середовище, заклад дошкільної освіти, особистісний розвиток, дитина дошкільного віку.

\section{Лimepamypa}

1. Артемова Л. Реалії та перспективи розвитку дошкільної освіти України в контексті ключових позицій Болонської декларації. Вісник Глухівського державного національного педагогічного університету ім. О. Довженка. 2010. Вип. 16. С. 10-14.

2. Бех І. Д. Особистість у контексті орієнтирів розвивального виховання. Інноватика у вихованні. 2015. URI : http://nbuv.gov.ua/UJRN/inuv2015_1_4

3. Выготский Л. С. Психология развития человека. Москва : Смысл; Эксмо, 2005.

4. Гавриш Н., Крутій К. Середовищна модель - панацея? Ламаємо стереотипи. Дошкільне виховання. 2019. № 4. С. 4-11.

5. Каган М. Системный подход и гуманитарное знание: Избр.ст. М. С. Кагана. Ленинград: изд-во ЛГУ, 1991.

6. Канішевська Л. В. Крокуємо до соціальної зрілості : наук.-метод. посіб. Київ : Ін-т проблем виховання НАПН України, 2011. 175 с.

7. Канішевська Л. В., Вишнівська Н. В. Педагогічні умови виховання гуманності в учнів молодшого шкільного віку в позаурочній діяльності шкіл-інтернатів // Topical issues of pedagogy: Collective monograph. - Edizioni Magi, Roma, Italy, 2019. 228 p.

8. Канішевська Л. В., Сухопара Л. В. Формування толерантності в молодших школярів у позаурочній діяльності: теорія і практика: монографія. Київ : Компринт, 2017. $405 \mathrm{c}$.

9. Кононко О. Л. Психологічні основи особистісного становлення дошкільника (системний підхід) : монографія. Київ: Стилос, 2000.

10. Крутій К. Освітній простір дошкільного навчального закладу : монографія: у 2-х ч. Київ : Освіта. 2009. Ч. 1.

11. Леонтьев О. М. Деятельность, сознание, личность. Москва : Наука, 1975.

12. Петько Л. В. Державний стандарт початкової освіти у ракурсі формування соціальної активності дитини. Наукові записки Бердянського державного педагогічного yн-my. Серія : Педагогіка : зб. наук. праць. - Бердянськ : БДПУ, 2018. Вип. 1. С. 92-97.

13. Петько Л. В. Особистість. Соціум. Навчальне середовище / Л.В. Петько // Гуманітарний вісник ДВНЗ «Переяслав-Хмельницький державний педагогічний університет імені Григорія Сковороди»: збірник наукових праць. Вип. 35. ПереяславХмельницький, 2014. С. 102-110. 
14. Петько Л. В. Підготовка майбутніх педагогів-вихователів до навчання іноземної мови дітей в дошкільних освітніх закладах. Вісник Інституту розвитку дитини. Вип. 23. Серія: Філософія, педагогіка, психологія: зб. наук. праць. Київ : Видво НПУ імені М.П.Драгоманова, 2012. С. 111-115.

15. Піроженко Т. О. Ігрова діяльність дошкільника: навчально-методичний посібник. Київ : Генеза, 2013.

16. Поніманська Т. Готовність до педагогічних інновацій у контексті гуманістичної педагогіки. Оновлення змісту і методів дошкільної освіти в Украӥні. 1999. Вип. 5. Рівне : РДПІ. С. 10-15.

17. Рубинштейн С. Л. Основы общей психологии: в 2-х т. Москва : Педагогика.

18. Слюсаренко Н., Кульбацька М. Суб'єкт-суб'єктний підхід до організації педагогічного процесу. Людинознавчі студіï. Педагогіка. 2015. № 1 (33). С. 194-201.

19. Становлення внутрішньої картини світу дошкільника: монографія / [Т.О. Піроженко, С.О. Ладивір, О.О. Вовчик-Блакитна та ін.]; за ред. Т.О. Піроженко. Кіровоград : Імекс-ЛТД. URI : http://lib.iitta.gov.ua/1604/

20. Эльконин Д.Б. Детская психология. Москва : Педагогика, 1960.

21. Якиманская И. Разработка технологии личностно ориентированного обучения Вопросы психологии. 1995. № 2. С. 37-38.

22. Matviienko O. Pedagogy of partnership in the process of setting new Ukrainian school // Challenges and opportunities of scientific thought development : collection of scientific articles. - GPG Publishing Group, Pretoria, South Africa, 2017. P. 151-156.

23. Matviienko Olena. Theoretical Basics of Preparation of Teachers to Pedagogical Interaction with Children of Various Age. Intellectual Archive. 2014. Volume 5. No. 5 (September). Toronto : Shiny Word Corp., Canada. Pp. 105-117. 


\title{
The Forming Professionally Oriented Foreign Language Communication Skills in Future Teachers of Ukrainian Primary School
}

\author{
Popova Liudmyla \\ ORCID http://orcid.org/ 0000-0002-2611-2786 \\ Associate Professor, Department of Foreign Languages and Teaching Methods \\ Dragomanov National Pedagogical University (Kyiv, Ukraine)
}

\begin{abstract}
The article focuses on the necessity of forming foreign language communicative skills in future primary school teachers as a condition of their successful professional activity and active integration into the European and the world educational space. The main emphasis in using a foreign language should be placed on mastering language and speech competences; it is necessary to develop future specialist's ability to communicate in a foreign language in real professional pedagogical situations in order to encourage the subjects of the educational process. The modern innovative teaching technologies form the basis of teaching the foreign language for specific purposes. These technologies bring them closer to their future professional duties, provide the opportunity to prepare for the teaching practice at school, and to acquire the necessary abilities and skills of communication with the primary school pupils.

Key words: future primary school teachers, communication, professional communication, pedagogical discourse, foreign language.
\end{abstract}

Introduction. The process of reforming education in Ukraine, its primary task is to increase the requirements for the professionalism of teachers, which presupposes not only a high level of personal culture, psychological readiness to work with students of different age groups, the ability for constant self-improvement, deep knowledge of academic subjects and mastery of the basics of teaching methods, but also the ability to diversifiedly interact with all participants in the educational process.

Review of previous studies. The fundamental foundations of the concept are the works of Ukrainian and foreign scholars in the writings, namely: the philosophy of continuing education (V. Andrushchenko, V. Kremen, I. Zyaziun, etc.); theoretical and methodological principles of professional training of future teachers, its components (V. Bondar, M. Yevtukh, O. Semenog); the essence of readiness and indicators of its formation (N. Volkova, L. Kondrashova, N. Kuzmina, V. Slastionin, etc.), the formation of professional readiness of future primary school teachers (O. Matvienko, O. Komar); some problems of the formation and development of personality in the process of preparation for professional activity and directly in its process are highlighted in the researches of L. Vygotskyi, O. Leontiev and others; 
using of the latest technologies and methods in teaching foreign languages for professional needs (V. Kalinin, S. Nikolaeva, L. Petko and others) $[3 ; 4 ; 7 ; 9 ; 10 ; 11 ; 12 ; 13 ; 16 ; 18 ; 19 ; 20$; 21].

A large number of studies have been devoted to the problem of communication and, personally, professional communication, but its relevance remains unchanged. Works on the study of this problem belong to such prominent scientists as O. Bodalyov, O. Leontiev and V. Kan-Kalik, who devoted their researches to pedagogical communication, N. Volkova focused on professional-pedagogical communication [1], psychology of professional communication was studied by L. Orban-Lembrik [8], theoretical bases of preparation of future primary school teachers for intercultural communication were regarded by L. Popova [13].

Results and discussions. The provisions of the "National Strategy for the Development of Education in Ukraine until 2021" (No 344/2013 25.06.2013) states that the result of its implementation should be the training and education of teachers who are able to work on the basis of innovative approaches to the organization of educational process, personal creative professional growth throughout life. Modernization and development of education and science must become proactive and continuous, flexible to respond to all processes taking place in the world. Quality education is a necessary condition for ensuring sustainable democratic development of society [14].

The legal framework governing the relevant professional activities is embodied in the articles of the Constitution of Ukraine No 1556-VII. 01.07.2014), The Law of Ukraine "On Education" (No 1556-VII. 01.07.2014), The Law of Ukraine "On General Secondary Education"(No 1556-VII. 01.07.2014), The Law of Ukraine "On Higher Education" (No 1556VII. 01.07.2014), National Doctrine of Education Development of Ukraine in the XXI Century (from 17.04.02. No 347 / 2002), The Concept of the New Ukrainian school (from 01.07.2014. No 1556-VII), The Concept of development of pedagogical education (from 01.07.2014. No 1556-VII), The State standard of primary education (from 01.07.2014. No 1556-VII), typical educational programs define the requirements for the system of knowledge and competencies of future teachers.

The Professional Standard for Primary School Teachers (from 17.04. 2002. No 347/2002) became the first professional standard in Ukraine to be approved at the national level. The document provides general information about the standard, training and professional 
development of teachers, as well as a specific list of its functions, namely: planning and implementation of the educational process; providing and supporting the education, upbringing and development of students in the educational environment and family; creating an educational environment; reflection and professional self-development; conducting pedagogical research; providing methodological assistance to colleagues on the issues of education, development, upbringing and socialization of primary school students of general secondary education; generalization of own pedagogical experience and its presentation to the pedagogical community; evaluation of the results of the work of primary school teachers of general secondary education [14].

According to the National Classifier of professions of Ukraine DK 009: 2010 "Classification of economic activities" specialists in this area by type of economic activity belong to section R "Education", section 85 "Education", group 85.2 "Primary education", class 85.20 "Primary education", the code of the name of the profession according to DK 003: 2010 "Classifier of professions" - 2331 "Teacher of primary classes of secondary education". A clear explanation was found in the document and the main types of job functions of primary school teachers. Consider, in our opinion, more significant.

Labor function A Planning and implementation of the educational process": A 1 U1. Find educational and methodical literature for the work of the teacher, including on the Internet; A 3U3. Make a plan for professional self-development; A 335. Methods, forms and means of ensuring interaction during the educational process; A 4U1. Collaborate and interact with relevant specialists regarding the planning of pedagogical influence...; A 336. Modern learning technologies in primary education; A 6U2. Organize various forms of educational work of students (individual, pair, group, collective, frontal) to provide feedback to the teacher;

Labor function B "Provision and support of education, upbringing, development of students in the educational environment and family": B 931 Powers of the teacher to involve stakeholders in the harmonious development of students; B 6U2. Take into account the age characteristics of students in the process of organizing educational interaction and feedback; B 733. Features of communication with parents (or persons replacing them); B 2U5. Organize cooperation with the school administration and other stakeholders.

Involvement of the future primary school teacher in the implementation of the following professional functions deserves special attention too, namely: Labor function D 
"Research"; Labor function W "Generalization of personal pedagogical experience and its presentation": Labor function F 2. Ability to disseminate their personal pedagogical experience by participating in methodological activities of different levels (school, district, city, regional, all-Ukrainian), presentations in the media and etc. [14].

An integral part of the teaching profession is intensive communication, which is carried out horizontally - communication with colleagues, employees of pedagogical institutions and vertically - communication with leaders and students, in the school and beyond in writing and in oral forms, contact method and indirectly (documentation and computer communication) and serves as the main means of solving multifaceted and pedagogical tasks [21]. We come to the conclusion that professional and pedagogical communication is an integral component of quality activities of primary school teachers, for the implementation of which in modern conditions a necessary aspect is the possession of foreign language skills. Professional and pedagogical communication can take place both orally and in writing.

Ukraine's integration into the world space, rapid development of scientific and technological innovations, globalization of social and economic processes necessitates the consideration of a foreign language as an important means of intercultural relations, a tool of communication in the dialogue of cultures and civilizations. In modern conditions of training future primary school teachers for the performance of their official duties and professional skills, the problem of communication in the field of pedagogical discourse is becoming increasingly important. In this context, scholars interpret the phenomenon of discourse from various aspects, namely: as a cognitive process associated with the creation of speech behavior [18]; as a sequence of interconnected statements, united by a common goal, as a means of conversation and thinking that can become ritualized [2]; and, finally, as a form of speech communication that involves the relationship between the speaker and the listener [16].

To analyze the process of communication, we need to define its structural components, which include: subjects, subject, need, motives, actions, tasks, tools, products and the environment in which the interaction between the participants of communication. To find out the essence of "professional communication", turn to the etymology of the term "communication". According to the definition of the academic dictionary, the term communication" comes from the Latin commūnicātio ("message", "transmission"), associated with the verb commūnico ("make common; report; connect") [13, p. 545]. In the early 
twentieth century, the word "communication" was used in the Library of Congress catalog only in the context of "Communication and Transportation" and "Military Communication". With the development of electronic means of communication, there was a need to consider communication as the transmission of information through technological channels.

The communicative approach to teaching foreign languages adopted in the modern domestic methodology determines the choice of goals, according to which the principles, content, methods, techniques and means of teaching are determined [5, p. 39]. Of course, all structural components of communication are interconnected and do not exist separately, which indicates that they belong to a single sphere of human interaction, in which they are active tools. In modern society, the concept of communication was used in many areas of human activity, first by technical specialists (physicists, technicians and engineers), and with the formation of the communication paradigm it was used by philosophers, sociologists, psychologists and educators to define interpersonal interaction in human society. It becomes obvious that communication as a category of knowledge is associated with different areas and contexts in different ways. The definition of the term "communication" has not become stable. According to the scientist V. Kashkin, there are almost as many definitions of this term as there are authors who studied it [6, p. 15].

Researcher A. Myroshnychenko identifies two types of professional communication, which depends on the professional affiliation of its participants, namely:

1) intraprofessional communication (communication between specialists of the same profession), for example: teacher - teacher, teacher - head-master of an educational institution, etc.; 2) interprofessional communication (communication between specialists of different professions), for example: teacher - student, teacher - parents of a student, etc. [15].

L. Orban-Lembrik distinguishes such varieties of professional communications as: representative, cognitive, persuasive, expressive, suggestive, ritual [8].

In defining the term "professional communication", we agree with the definition by N. Volkova, who characterizes this phenomenon as a system of direct or indirect connections, interactions of specialists, realized through verbal and nonverbal means of communication to exchange information, model and manage the communication process, regulation of professional relations [1]. 
Conclusions and prospects for further explorations. Thus, the characteristic features of professional communication of future primary school teachers in modern conditions include: the activity of its participants in a single communicative space; identical understanding by the subjects of communication of professionally-oriented information and communication situation; the presence of mutual understanding between the participants of communicative interaction, which is produced not only by the possession of language tools, but also by the psychological characteristics of the interlocutors, due to which feedback is achieved. The development of communication skills in a foreign language for professional needs opens for primary school teachers the significant prospects for further self-improvement, compliance with the requirements of the time and decent competitiveness.

\section{References}

1. Volkova N.P. Profesiino-pedahohichna komunikatsiia: navchalnyi posibnyk. [Professional and pedagogical communication. Teaching]. Kyiv : Akademia, 2006. 256 p.

2. Hrebinnyk L. V., Petko L V. Nimetska mova dlia vstupnykiv do mahistratury zi spetsialnostei: 8.01010101 «Doshkilna osvita», 8.01010201 «Pochatkova osvita» [German language for entrants to the master's degree in specialties: 8.01010101 "Preschool education", 8.01010201 "Primary education"]: navch. navch. posibnyk. 2-e vyd., stereotypne ; za red. Bondaria V.I., Honcharova V.I. Kyiv : Un-t «Ukraina», 2015. 162 p.

3. Etymolohichnyi slovnyk ukrainskoi movy [Etymological dictionary of the Ukrainian language]: u 7 t. / hol. red.. O.S. Melnychuk. Kyiv : Naukova dumka, 1985. Vol. 2.

4. Matviienko O. V., Popova L. M. Akademichna mobilnist yak skladova pidhotovky maibutnikh vchyteliv do mizhkulturnoi komunikatsii v umovakh yevrointehratsii [Academic mobility as a component of training future teachers for intercultural communication in the context of European integration.]. Innovatsiina pedahohika. 2020. Issue 21. No 2. Pp.147-150.

5. Metodyka navchannia inozemnykh mov i kultur: teoriia i praktyka [Methods of teaching foreign languages and cultures: theory and practice] : pidruchnyk / za red. S. Yu. Nikolaievoi. Kyiv : Lenvit, 2013. 590 p.

6. Natsionalna stratehiia rozvytku osvity v Ukraini na 2012-2021 roky [National strategy for the development of education in Ukraine for 2012-2021]: (from 25. 2013 No 344/2013). Shk. b-ka plus. 2013. November. (No 21/22). P. 1-26.

7. Nikolaienko V. V., Petko L. V. Anhliiska mova dlia vstupnykiv do mahistratury zi spetsialnostei: 8.01010101 «Doshkilna osvita», 8.01010201 «Pochatkova osvita» [English for entrants to the master's degree in specialties: 8.01010101 "Preschool education", 8.01010201 "Primary education"]: navch. posibnyk dlia studentiv, bakalavriv ta aspirantiv VNZ. 2-he vyd., stereotypne / za red. Andrushchenka V. P. Kyiv : VDK «Ukraina», 2012. 140 p. 
8. Orban-Lembrik L. E. Sotsialna psykholohiia [Social Psychology] : pidruchnyk : In 2 books. Book 1: Social psychology of personality and communication. Kyiv : Lybid, 2004. 576 p.

9. Pet'ko L. V. Inshomovna osvita u konteksti formuvannja novogo vchytelja $v$ umovah universytets'koi' pidgotovky [University foreign language education in the context of the formation of a new teacher]. Pedagogika vyshhoi' ta seredn'oi' shkoly: [zb.nauk.prac'] ; za red. Z. P. Bakum. Kryvoriz'kyj pedagogichnyj in-t DVNZ «Kryvoriz'kyj nacional'nyj un-t». Issue 39. Kryvyj Rig : Drukarnja Romana Kozlova, 2013. Pp. 232-237.

10. Pet'ko L.V. Navchannja inozemnoi' movy ditej startuje u pochatkovij shkoli (rozdumy shhodo provedennja kontrol'nyh robit MONMS Ukrai'ny z inozemnoi' movy) [The Pupils' Training in Foreign Language begins in Elementary School (contemplating the conducting tests in Foreign language by the Ministry of Education and Science of Ukraine)]. Dyrektor shkoly, liceju, gimnazii'. 2011. No 4. Pp. 97-100.

11. Pet'ko L. V. Pidgotovka majbutnih pedagogiv-vyhovateliv do navchannja inozemnoi' movy ditej $v$ doshkil'nyh osvitnih zakladah [The ways of a process of preparation of future tutors in foreign language teaching of preschool children]. Visnyk Instytutu rozvytku dytyny. Issue 23. Serija: Filosofija, pedagogika, psyhologija: Zbirnyk naukovyh prac'. Kyiv : Vyd-vo NPU imeni M.P.Dragomanova, 2012. Pp. 111-115.

12. Pet'ko L.V. Profesijna pidgotovka vchyteliv pochatkovoi' osvity ta formuvannja profesijno orijentovanogo inshomovnogo navchal'nogo seredovysha $v$ umovah universytetu [Professional preparing primary education teachers and formation of professionally oriented foreign language learning environment at the university] // Innovacijni tehnologii v organizacii vyhovnoi roboty u pochatkovij shkoli: Tr. Vseukr. nauk.-prakt. seminaru (10 ljutogo 2016 r.), Umans'kyj derzh. ped. un-t imeni Pavla Tychyny. Uman : FOP Zhovtyj, 2016. Pp. 72-76.

13. Popova L.M. Teoretychni osnovy pidhotovky maibutnikh uchyteliv pochatkovoi shkoly do mizhkulturnoi komunikatsii [Theoretical bases of preparation of future primary school teachers for intercultural communication]. Bulletin of Alfred Nobel University: Series "Pedagogy and Psychology". Pedagogical sciences. 2019. No. 2 (18). Pp. 229-235.

14. Profesiinyi standart na profesiiu «Vchytel pochatkovoi shkoly» [Professional standard for the profession "Primary school teacher"]. URI: https: //www.auc.org.ua/sites/default/files/sectors/u137/standart_uchytelya_pochatkovoyi_shkoly.pdf

15. Ryb G. G. Sutnist poniattia «profesiina komunikatsiia medychnykh pratsivnykiv serednoi lanky» ta yii riznovydy. [The essence of the concept of "professional communication of mid-level medical workers" and its varieties]. Bulletin of Taras Shevchenko Lviv National University No 15 (274), 2013. URI : file:///D:/Downloads/vlup_2013_15_13\%20(1).pdf

16. Matviienko O. Pedagogy of partnership in the process of setting new Ukrainian school // Challenges and opportunities of scientific thought development : collection of scientific articles. - GPG Publishing Group, Pretoria, South Africa, 2017. Pp. 151-156.

17. Matviienko Olena. Pedagogical situations and tasks as means of training for professional activity // Economics, management, law : challenges and prospects: Collection of scientific articles. Psychology. Pedagogy and Education. - Discovery Publishing House Pvt. Ltd., New Delhi, India. 2016. Pp. 204-208. 
18. Matviienko Olena. Theoretical bases of teacher's professional formation // Economics, management, law: socio-economical aspects of development: Collection of scientific articles. Vol. 2. Psychology. Pedagogy and Education. - Edizioni Magi - Roma, Italy. 2016. Pp. 237-239.

19. Pet'ko L. V. Teaching of students' professionally oriented foreign language writing in the formation of professionally oriented foreign language learning environment // Economics, management, law: innovation strategy: Collection of scientific articles. - Henan Science and Technology Press, Zhengzhou, China, 2016. Pp. 356-359.

20. Popova Ludmila. Formation of the preparation of future primary school teachers for intercultural professional communication by the means of innovative educational technologies // Research and Innovation: Collection of scientific articles. - Y unona Publishing, New York, USA, 2020. 216 p. Pp. 196-200.

21. Popova, Liudmila. Rethinking of future primary school teacher's training for the professional communication by means of English in the 21st century // Education of the XXI century: realities, challenges, tendencies of development: collective monograph / science ed. prof. Tsvetkova Anna. Hameln: InterGING, 2020. Pp. 444-462.

URI : https://intergingpublishing.wordpress.com/2018/07/04/monographie/

\section{Translation of the Title, Abstract and References to the Author's Language}

\section{УДК 378}

Попова Людмила. Формування іншомовних професійно оріснтованих навичок комунікації майбутніх учителів початкової школи України.

У статті розкривається необхідність формування іншомовних комунікативних навичок майбутніх вчителів початкової школи як умова їх успішної професійної діяльності та активної інтеграції в європейський та світовий освітній простір. Доведено, що основний акцент у використанні іноземної мови в професійній діяльності вчителя повинен бути зроблений на оволодіння мовними та мовленнєвими навичками; необхідності розвивати вміння майбутнього спеціаліста в спілкуванні іноземною мовою в реальних професійних педагогічних ситуаціях 3 метою заохочення суб'єктів навчально-виховного процесу. Сучасні інноваційні технології навчання складають основу викладання іноземної мови для конкретних цілей, які наближають фахівця до своїх майбутніх професійних обов'язків, дають можливість підготуватися до викладацької практики в школі, набути необхідних здібностей та навичок спілкування 3 учнями початкових класів.

Ключові слова: майбутні вчителі початкових класів, спілкування, професійне спілкування, педагогічний дискурс, іноземна мова.

\section{Література}

1. Волкова Н. П. Професійно-педагогічна комунікація: навчальний посібник. Київ : Академія, 2006. 256 с.

2. Гребінник Л В., Петько Л.В. Німецька мова для вступників до магістратури зі спеціальностей: 8.01010101 «Дошкільна освіта», 8.01010201 «Початкова освіта»: навч. навч. 
посібник. 2-е вид., стереотипне ; за ред. Бондаря В.І., Гончарова В.I. Київ : Університет «Україна», 2015. 162 с.

3. Етимологічний словник української мови: у 7 т. / гол. ред.. О.С. Мельничук. Київ : Наукова думка, 1985. Т. 2.

4. Матвієнко О. В., Попова Л. М. Академічна мобільність як складова підготовки майбутніх вчителів до міжкультурної комунікації в умовах євроінтеграції. Інноваційна педагогіка. 2020. Вип. 21. Том 2. 2020. С.147-150.

5. Методика навчання іноземних мов і культур: теорія і практика : підручник / за ред. С. Ю. Ніколаєвої. Київ : Ленвіт, 2013. 590 с.

6. Національна стратегія розвитку освіти в Україні на 2012-2021 роки : затв. Указом Президента України від 25 черв. 2013 р. № 344/2013. Шк. б-ка плюс. 2013. Листоп. № 21/22. C. 11-26.

7. Ніколаєнко В. В., Петько Л. В. Англійська мова для вступників до магістратури зі спеціальностей: 8.01010101 «Дошкільна освіта», 8.01010201 «Початкова освіта»: навч. посібник для студентів, бакалаврів та аспірантів ВНЗ. 2-ге вид., стереотипне / за ред. Андрущенка В. П. Київ : ВДК «Україна», 2012. 140 с.

8. Орбан-Лембрик Л. Е. Соціальна психологія: підручник: У 2 кн. Кн. 1: Соціальна психологія особистості та спілкування. Київ : Либідь, 2004. 576 с.

9. Петько Л. В. Іншомовна освіта у контексті формування нового вчителя в умовах університетської підготовки. Педагогіка вищої та середньої школи: зб.наук.праць ; за ред. 3. П. Бакум. Криворізький педагогічний інститут ДВНЗ «Криворізький національний університет». Вип. 39. Кривий Ріг : Друкарня Романа Козлова, 2013. С. 232-237.

10. Петько Л.В. Навчання дітей іноземної мови стартує у початковій школі (роздуми щодо проведення контрольних робіт МОНМС України з іноземної мови). Директор школи, лічею, гімназії: всеукр. наук.-практ. журнал / засн. МОНмолодьспорту України, НАПН України, НПУ імені М.П.Драгоманова ; голов. ред. О.І. Виговська. 2011. № 4. С. 97-100.

11. Петько Л. В. Підготовка майбутніх педагогів-вихователів до навчання іноземної мови дітей в дошкільних освітніх закладах. Вісник Інституту розвитку дитини. Вип. 23. Серія: Філософія, педагогіка, психологія: зб. наук. праць. Київ: Вид-во НПУ імені М.П.Драгоманова, 2012. С. 111-115.

12. Петько Л. В. Професійна підготовка вчителів початкової освіти та формування професійно орієнтованого іншомовного навчального середовища в умовах // Інноваційні технології в організації виховної роботи у початковій школі: Тр. Всеукр. наук.-практ. семінару (10 лютого 2016 р.), Уманський держ. пед. ун-т імені Павла Тичини. Умань : ФОП Жовтий, 2016. С.72-76.

13. Попова Л. М. Теоретичні основи підготовки майбутніх учителів початкової школи до міжкультурної комунікації. Вісник Університету імені Альфреда Нобеля: Серія «Педагогіка і психологія». Педагогічні науки. 2019. № 2 (18). С. 229-235. 
14. Професійний стандарт на професію «Вчитель початкової школи». URI : https://www.auc.org.ua/sites/default/files/sectors/u137/standart_uchytelya_pochatkovoyi _shkoly.pdf

15. Риб Г. Г. Сутність поняття «професійна комунікація медичних працівників середньої ланки» та їі різновиди. Вісник ЛНУ імені Тараса Шевченка. 2013. № 15 (274). URI : file:///D:/Downloads/vlup_2013_15_13\%20(1).pdf

16. Matviienko O. Pedagogy of partnership in the process of setting new Ukrainian school // Challenges and opportunities of scientific thought development : collection of scientific articles. - GPG Publishing Group, Pretoria, South Africa, 2017. Pp. 151-156.

17. Matviienko Olena. Pedagogical situations and tasks as means of training for professional activity // Economics, management, law : challenges and prospects: Collection of scientific articles. Psychology. Pedagogy and Education. - Discovery Publishing House Pvt. Ltd., New Delhi, India. 2016. Pp. 204-208.

18. Matviienko Olena. Theoretical bases of teacher's professional formation // Economics, management, law: socio-economical aspects of development: Collection of scientific articles. Vol. 2. Psychology. Pedagogy and Education. - Edizioni Magi - Roma, Italy. 2016. Pp. 237-239.

19. Pet'ko L.V. Teaching of students' professionally oriented foreign language writing in the formation of professionally oriented foreign language learning environment // Economics, management, law: innovation strategy: Collection of scientific articles. - Henan Science and Technology Press, Zhengzhou, China, 2016. Pp. 356-359.

20. Popova Ludmila. Formation of the preparation of future primary school teachers for intercultural professional communication by the means of innovative educational technologies // Research and Innovation: Collection of scientific articles. - Yunona Publishing, New York, USA, 2020. 216 p. Pp. 196-200.

21. Popova, Liudmila. Rethinking of future primary school teacher's training for the professional communication by means of English in the 21st century // Education of the XXI century: realities, challenges, tendencies of development: collective monograph / science ed. prof. Tsvetkova A. Hameln: InterGING, 2020. Pp. 444-462.

URI : https://intergingpublishing.wordpress.com/2018/07/04/monographie/ 


\title{
Modeling the Process of Forming Culture in Professional Activities of Future Managers
}

\author{
Honchar Lubov \\ Candidate of Economical Sciences \\ Associate professor of accounting and auditing department \\ Donbass State Pedagogical University (city Sloviansk, Ukraine)
}

\begin{abstract}
The article deals with different scientific approaches to understanding the modeling of the process in forming the culture of future managers' professional activity. The essential characteristics of the concepts «model», «modeling», «professional culture», «professional culture of future managers», «culture of future managers' professional activity» are revealed. The culture of future managers' professional activity is identified with the phenomenon of managerial culture and characterizes the latter as a process and result of the social environment, which provides optimally favorable working conditions, individual development and selfrealization of all members of the staff. The term "modeling" is defined as the process and method of cognition, as well as the method of cognitive and management activities. The functions of future managers' management activities are defined. Emphasized that the components of the model of forming the culture of professional activity of future managers help to objectively convey information about the contents, purpose, nature and result of future professional activity of managers. The structural elements of the model of culture in professional activities of future managers are distinguished, namely: methodological, substantive, organizational-technological, methodological-targeted, object-content, procedural and diagnostic-effective. Information is presented on the types of competence models of world standards (basic types of competences), such as: SHL model (international management standards - specialist, manager, group leader); the S. Whiddett \&S. Hoolfordford model (developing a competency model based on organization materials); the Society for Human Resource Management model; Corporate Financial Technology model.
\end{abstract}

Key words: culture, future manager, model, modeling, professional activities.

Актуальність дослідження. Швидкі зміни в соціально-економічному, політичному житті країни, викликані вроінтеграційними, глобалізаційними, інтеграційними процесами та об'єктивними потребами сучасного ринку праці, зумовлюють підвищення вимог до рівня якості надання професійних знань майбутнім менеджерам, a також навчально-методичного, науково-методичного та інформаційного забезпечення освітнього процесу. Відтак, сучасний менеджер повинен володіти не тільки грунтовними професійними знаннями, але й вміти ефективно застосовувати наукові методи аналізу, діагностувати проблему, пропонувати альтернативні рішення, коригувати діяльність організації; оперативно приймати управлінські рішення; вирішувати нестандартні проблеми; володіти кваліфікацією на рівні прийнятого рішення; володіти комунікативністю, комунікабельністю, вирізнятися стратегічністю мислення; наявністю певного рівня економічних, організаційно- 
управлінських, психологічних, технічних та інших знань, необхідних для вирішення професійних завдань. Відтак, доцільним в межах окресленої проблеми стає обгрунтування моделі культури професійної діяльності майбутніх менеджерів, а також іiі структурних компонентів.

Аналіз наукової літератури з проблеми дослідження дає підстави стверджувати, що проблемі моделювання процесу формування культури професійної діяльності майбутніх менеджерів приділяється належна увага в багатьох наукових дослідженнях, зокрема, таким iï аспектам: формуванню професійної культури майбутніх менеджерів (Л. Батченко, О. Виговська, Т. Глушман, М. Гриньова, М. Дробноход, М. Захаров, В. Жигірь, Л. Каращук, Н. Коломинський, О. Крупський, С. Крисюк, С. Намлієв, Р. Шакуров та ін.); основам моделювання (В. Штофф); моделюванню певних аспектів багатомірної педагогічної реальності (В. Віденко, Л. Капченко, Є. Лодатко, А. Цимбалару та ін.); парадигмальному моделюванню у професійній підготовці майбутніх учителів (Л. Петько, А. Семенова) $[1 ; 6 ; 7 ; 8 ; 15 ; 16 ; 17]$.

Mema cmammi - теоретичне обгрунтування наукових підходів щодо моделювання процесу формування культури професійної діяльності майбутніх менеджерів.

Виклад основного матеріалу. Термін «професійна культура» підкреслює, що культура розглядається як специфічна якість діяльності фахівця та розкриває предметний зміст культури, який визначається специфікою професії, професійної діяльності та професійного співтовариства [9].

Професійну культуру менеджера слід розглядати як високий рівень професіоналізму людини, як спосіб творчої самореалізації в професійній діяльності, як процес освоєння, передачі професійних цінностей, становлення системи особистісних сенсів, які розглядаються як ступінь якості професійної діяльності та життя людини $[2 ; 9]$.

Науковець О. Ельбрехт [3], культуру професійної діяльності менеджера ототожнює з явищем управлінської культури і характеризує останню як процес і результат соціального середовища, що забезпечує оптимально сприятливі умови праці, індивідуального розвитку і самореалізації всіх членів трудового колективу. У своїй професійній діяльності менеджер здійснює функцію управлінця, тому його професійна культура певною мірою розкривається через зміст управлінської культури, яка включає 
в себе сукупність цінностей, переконань, відносин, загальних для всіх співробітників організації, які зумовлюють норми їх поведінки і представляють собою основний компонент в досягненні управлінських цілей [13].

Поняття «модель» (з французької мови modele - міра, зразок, норма; у перекладі 3 латини - образ, зменшений варіант, спрощений опис складного явища чи процесу) трактується як зразок, що відтворює, імітує будову та дію будь-якого об’єкта, а, відтак, використовується для отримання нових знань про об’єкт [12, с. 196]. Термін «модель» у науці використовується як будь-який уявний, знаковий або матеріальний образ модельованого об'єкта (оригіналу): відображення об'єктів і явищ у вигляді описів, теорій, схем, креслень, графіків.

Моделювання визначається науковцями як процес та метод пізнання, що дає змогу вивчати певні загальні закономірності, оскільки модель допомагає пояснити накопичені факти навіть тоді, коли ще не має розробленої теорії [14, с. 191]; як метод пізнавальної та управлінської діяльності, який уможливлює адекватний опис і цілісне відображення в модельних уявленнях сутності, найважливіших якостей та компонентів системи, отримання інформації про іiі минулий та майбутній стан та умови побудови, функціонування та розвитку [4, с.120].

Важливу роль в аналізі зазначеної проблеми відіграє модель компетенції як теоретична система знань, умінь, навичок персоналу, що забезпечують організації реалізацію завдань менеджменту. Модель уніфікує вимоги до співробітників і створює єдині стандарти функціонування, основу для оцінки та просування працівників. Відтак, слід навести приклади моделей компетенцій світових стандартів (базові типи компетенцій), як от: модель SHL; модель S. Whiddett \& S. Hoolyforde; модель Society for Human Resource Management; модель «Корпоративні фінансові технологіï» [10].

У відповідності до моделі SHL (міжнародні стандарти керування - фахівець, менеджер, керівник групи), майбутній менеджер має володіти наступними типами компетенцій, серед яких: підприємницькі якості (творчість, гнучкість мислення, рішучість, стратегія); особистісні риси керівника (лідерство, служіння, планування й організація своєї управлінської діяльності, орієнтація на якість та результат, переконливість, цілеспрямованість); професійні якості (компетентність, спеціальні 
знання, стресостійкість, комунікабельність); особистісні якості (емпатійність, порядність, чесність, гнучкість, вмотивованість) [10].

Модель S. Whiddett \& S. Нооlyforde (розробка моделі компетенщій на матеріалах організаціїі) виділяє такі типи компетенцій: розвиток бізнесу (особистий розвиток, генерування й обгрунтування ідей); досягнення результатів (планування, чіткість менеджменту, постановка цілей); аналіз - робота 3 інформацією (аналіз і прийняття рішень); люди (робота в команді, вплив, керування відносинами) [10].

Модель Society for Human Resource Management (модель для керування колективом) виділяє наступні типи компетенцій: знання бізнесу; персональна дієздатність; стратегічний внесок; практичні навички та володіння технологіями менеджменту.

Модель «Корпоративні фінансові технологї̈» виділяє такі типи компетенцій: системність та гнучкість мислення; швидкість прийняття рішень; орієнтація на результат; аналітичне мислення; креативність; швидкість реакції; здатність до безперервного навчання; організаторські та ораторські здібності; делегування повноважень; розуміння основ тайм менеджменту; вміння працювати в команді; переконувати, доводити та відстоювати власну думку; уміння слухати та прислухатися до інших, підтримувати feedback; навички проведення презентацій і переговорів; здатність ретранслювати свої знання та навички [10].

С. Криштанович [5] у своїх дослідженнях зазначає, що сучасна модель формування культури професійної діяльності майбутніх менеджерів має включати систему компонентів, які будуть об'єктивно доносити інформацію щодо змісту, мети, характеру та результату майбутньої професійної діяльності менеджерів. Відтак, в основу моделі формування культури професійної діяльності майбутніх менеджерів, вона закладає наступні блоки, а саме: методично-цільовий, предметно-змістовий, процесуальний та діагностично-результативний.

Методично-иільовий блок моделі розкриває мету формування культури професійної діяльності майбутніх менеджерів у процесі їх фахової підготовки, усвідомлення майбутніми менеджерами мети і завдань їх професійної підготовки, послідовне формування у них цілей і завдань на кожному з етапів навчання. Він також 
передбачає формування операційно-процесуальної складових майбутньої професійної діяльності менеджера [5, с. 50].

Предметно-змістовий блок містить систему знань, умінь та навичок з професійноорієнтованих дисциплін, структурні компоненти формування професійних компетентностей майбутніх менеджерів, їх функції, принципи, методи, форми та засоби, а також організаційно-педагогічні умови формування культури їх професійної діяльності. Зміст означеного блоку спрямований на реалізацію навчальної, пізнавальної та розвивальної функцій майбутніх менеджерів. Тобто володіння ними системою знань щодо фахової діяльності, формування професійних умінь, розвиток професійних здібностей [5, с. 50].

Прочесуальний блок характеризує підходи, принципи, методи, форми, засоби формування культури професійної діяльності майбутніх менеджерів під час їх фахової підготовки. Цей блок відображає організаційно-методичні умови особистісноорієнтованої професійної підготовки майбутніх менеджерів, що мають бути зорієнтовані на оптимальний вибір засобів навчання, системність, науковість та доступність подачі знань, зв'язок теорії з практикою.

Діагностично-результативний блок визначає критерії та рівень сформованості культури професійної діяльності майбутніх менеджерів, які відображають рівень сформованості професійної компетентності майбутніх менеджерів та ії складових, а також розкривають професійне самовизначення, професійну самореалізацію, самоактуалізацію особистості майбутніх менеджерів [5, с. 50].

На думку науковця, для реалізації успішної підготовки менеджера та розвитку його професійної культури рекомендована модель має містити науково обгрунтовані нормативи та вимоги до змісту його професійної діяльності та навиків особистості, як фахівця, що дозволить їм ефективно виконувати визначені функціональні обов'язки.

Через що. у своїх наукових пошуках О. Слободянюк виокремлює такі структурні компоненти моделі: методологічний, змістовий, організаційно-технологічний [11], де методологічний компонент включає мету, основні підходи та принципи процесу формування культури професійної діяльності майбутніх менеджерів. Змістовий компонент передбачає характеристику компонентів культури професійної діяльності майбутніх менеджерів: мотиваційно-ціннісного, когнітивного, діяльнісного та 
особистісного. Організаційно-технологічний компонент моделі охоплює такі складові: критерії, показники та рівні сформованості; методику діагностування; педагогічні умови та етапи формування культури професійної діяльності майбутніх менеджерів.

Висновки. Таким чином, у поняття «моделювання культури професійної діяльності майбутніх менеджерів» вчені вкладають різний зміст. Більшість розробників цієї проблеми розуміють під моделлюванням культури професійної діяльності майбутніх менеджерів систему компонентів, що відображають інформацію щодо змісту, мети, характеру та результату майбутньої професійної діяльності менеджерів.

\section{References}

1. Hlushman T. M. Komponenty profesiinoi kultury maibutnoho menedzhera orhanizatsii [Components of the professional culture of the future manager of organizations]. Scientific Journal «ScienceRise: Pedagogical Education». 2016. No 5. Pp. 8-13.

2. Honchar L. V. Metodolohichni pidkhody do formuvannia profesiinoi kultury maibutnikh menedzheriv [Methodological approaches to the formation of professional culture of future managers]. Pedahohika formuvannia tvorchoi osobystosti u vyshchii i zahalnoosvitnii shkolakh. 2019. No 67. Vol. 2. Pp. 163-165.

3. Elbrekht O. M. Pidhotovka menedzheriv u vyshchykh navchalnykh zakladakh Velykoi Brytanii, Kanady, SShA [Training of managers in higher educational institutions of Great Britain, Canada, the USA] : avtoref. dys. na zdobuttia nauk. stupenia d-ra ped. nauk, Nats ped. un-t im. M. P. Drahomanova, Kyiv. 2011. 20 c.

4. Kraevskyi V. V. Metodolohycheskaia pedahohyka [Methodological pedagogy]: posobye dlia pedahohov-issledovatelei. Cheboksary : Izd-vo Chuvash.un-ta, 2001. 244 p.

5. Kryshtanovych S. Tsinnist modeli formuvannia profesiinoi kompetentnosti maibutnikh menedzheriv fizychnoi kultury $i$ sportu [The value of the model of formation of professional competence of future managers of physical culture and sports]. Molod i rynok. 2018. Vol. 9 (164). Pp. 49-54.

6. Pet'ko L. V. Inojazychnoe obuchenie budushhih menedzherov obrazovatel'noj sfery $v$ uslovijah universitetskoj podgotovki [Foreign languge preperation of future managers of educational institutions in the term of university education]. Innovacii v obrazovanii. Moskva : Sovremennaja gumanitarnaja akademija, 2013. No 12. Pp. 36-45.

7. Pet'ko L. V. Pidgotovka novogo pedagoga-ekonomista - vyklyk suchasnij pedagogichnij universytets'kij osviti (na prykladi stvorennja novyh navchal'nyh program z inozemnoi' movy za fahom zi special'nosti 6.030601 «Menedzhment (upravlinnja personalom)» [The preparation of a future teacher in economics as a claim for modern higher school pedagogical education (by way the illustration of the new study programs in specialty 6.030601 «Management» of the discipline «Foreign language in professional sphere»]. Visnyk Instytutu rozvytku dytyny. Vyp. 27. Serija: Filosofija, pedagogika, psyhologija: zb. nauk. prac. Kyiv: Vyd-vo NPU imeni M.P.Dragomanova, 2013. Pp. 95-101. 
8. Petko S. M. Modeli korporatyvnoho upravlinnia v diialnosti korporatsii na svitovykh rynkakh [Tekst]. Molodyi vchenyi. 2015. No 2 (17). Ch. 2. Pp. 225-229.

9. Romanovskyi O. Shliakhy vprovadzhennia innovatsii, pidpryiemnytstva ta pidpryiemnytskoi osvity $\mathrm{v}$ systemi natsionalnoi osvity Ukrainy [Ways of introduction of innovations, entrepreneurship and entrepreneurial education in the system of national education of Ukraine]: monohrafiia. Vinnytsia : Nova knyha. 2010. 416 p.

10. Saukh I. V. Modeli profesiinoi kompetentnosti menedzhera turystychnoi industrii yak osnova konkurentospromozhnosti haluzi [Models of professional competence of the tourism industry manager as the basis of industry competitiveness]. Ekonomika. Upravlinnia. Innovatsii. 2010. Vol. 2 (4). URI : http://nbuv.gov.ua/UJRN/eui_2010_2_38

11. Slobodianiuk O. M. Formuvannia profesiino-etychnoi kompetentnosti maibutnikh menedzheriv ekonomichnoho profiliu $u$ protsesi vyvchennia suspilno-humanitarnykh dystsyplin [Formation of professional and ethical competence of future managers of economic profile in the process of studying social sciences and humanities] : avtoref. dys. ... kand. ped. nauk : 13.00.04. Nats. akad. ped. nauk Ukrainy, In-t vyshch. osvity. Kyiv, 2017. 20 p.

12. Slobodianiuk A. V., Andrushchenko N. O. Psykholohiia upravlinnia ta konfliktolohiia [Psychology of management and conflictology]: navch. posibnyk dlia praktychnykh ta seminarskykh zaniat. Vinnytsia : VNTU. 2010. 120 p.

13. Stepanjuk T. V. Socialnye faktory formirovanija i razvitija upravlencheskoj kultury $v$ mezhnacionalnyh organizacijah [Social factors of formation and development of managerial culture in interethnic organizations] : avtoref. dis. kand. sociol. nauk, Moskva, 2006.

14. Teoretychni $i$ metodychni zasady modeliuvannia fakhovoi kompetentnosti kerivnykiv zakladiv osvity [Theoretical and methodical bases of modeling of professional competence of heads of educational institutions] : monohrafiia / H. V. Yelnykova [ ta in. ]; za red. H. V. Yelkovoi. Kyiv-Chernivtsi : Knyhy XXI, 2010. 460 p.

15. Pet'ko Lyudmila. Developing students' creativity in conditions of university // Research: tendencies and prospects: Collection of scientific articles. - Editorial Arane, S.A. de C.V., Mexico City, Mexico, 2017. P. 272-276.

16. Bodnarchuk O., Bodnarchuk O., Ersozoglu R., Kanishevska L., Pet'ko L., Turchynova G. \& Vyshnivska N. Model of Entrepreneurial Corporate Education and Prospects of Professional Development of Managers in Ukraine. Journal of Entrepreneurship Education. 2019. No 22(2).

17. Sabat N., Ersozoglu R, Kanishevska L., Pet'ko L., Spivak Yar., Turchynova G., Chernukha N. Staff development as a condition for sustainable development entrepreneurship. Journal of Entrepreneurship Education (JEI). USA. Special Issue (March-2019) "Entrepreneurship : Investment and Innovation". 2019. Vol. 22. Pp. 1-7.

Translation of the Title, Abstract and References to the Author's Language

\section{УДК 005.95-051:174}

Гончар Любов. Моделювання процесу формування культури професійної діяльності майбутніх менеджерів. 
Розглянуто підходи до моделювання процесу формування культури професійної діяльності майбутніх менеджерів. Розкрито сутнісні характеристики понять «модель», «моделювання», «професійна культура», «професійна культура майбутніх менеджерів», «культура професійної діяльності майбутніх менеджерів». Виокремлено структурні елементи моделі культури професійної діяльності майбутніх менеджерів, а саме: методологічний, змістовий, організаційно-технологічний, методично-цільовий, предметно-змістовий, процесуальний та діагностично-результативний. Представлено інформацію щодо видів моделей компетенцій світових стандартів (базові типи компетенцій), як от: модель SHL (міжнародні стандарти керування - фахівець, менеджер, керівник групи); модель S. Whiddett \& S. Hoolyforde (розробка моделі компетенцій на матеріалах організації); модель Societ2 for Human Resource Management (модель для керування колективом); модель «Корпоративні фінансові технології».

Ключові слова: культура, культура професійної діяльності, майбутні менеджери, модель, моделювання.

\section{Лimepamypa}

1. Глушман Т. М. Компоненти професійної культури майбутнього менеджера організацій. Scientific Journal «ScienceRise: Pedagogical Education». 2016. № 5. C. 8-13.

2. Гончар Л. В. Методологічні підходи до формування професійної культури майбутніх менеджерів. Педагогіка формування творчої особистості у вищій $i$ загальноосвітній школах. 2019. № 67. Т. 2. С. 163-165.

3. Ельбрехт О. М. Підготовка менеджерів у вищих навчальних закладах Великої Британії, Канади, США : автореф. дис. на здобуття наук. ступеня д-ра пед. Наук / Нац пед. ун-т ім. М. П. Драгоманова, Київ, 2011. 20 с.

4. Краевский В. В. Методологическая педагогика: пособие для педагоговисследователей. Чебоксары : Изд-во Чуваш.ун-та, 2001. 244 с.

5. Криштанович С. Цінність моделі формування професійної компетентності майбутніх менеджерів фізичної культури і спорту. Молодь і ринок. № 9 (164). 2018. C. 49-54.

6. Петько Л. В. Иноязычное обучение будущих менеджеров образовательной сферы в условиях университетской подготовки. Инноващии в образовании : научнометодический журнал / учред. Современная гуманитарная академия ; гл. ред. И.В.Сыромятников. Москва : Современная гуманитарная академия, 2013. № 12. С. $36-$ 45 .

7. Петько Л. В. Підготовка нового педагога-економіста - виклик сучасній педагогічній університетській освіті (на прикладі створення нових навчальних програм 3 іноземної мови за фахом зі спеціальності 6.030601 «Менеджмент (управління персоналом)». Вісник Інституту розвитку дитини. Вип. 27. Серія: Філософія, педагогіка, психологія: зб. наук. праць. Київ : Вид-во НПУ імені М.П.Драгоманова, 2013. С. 95-101.

8. Петько С. М. Моделі корпоративного управління в діяльності корпорацій на світових ринках [Текст]. Молодий вчений. 2015. №2 (17). Ч. 2. С. 225-229.

9. Романовський О. Шляхи впровадження інновацій, підприємництва та підприємницької освіти в системі національної освіти України : монографія. Вінниця : Нова книга, 2010. 416 с. 
10. Саух I. В. Моделі професійної компетентності менеджера туристичної індустрії як основа конкурентоспроможності галузі. Економіка. Управління. Інновацї̈. 2010.№ 2 (4). URI :http://nbuv.gov.ua/UJRN/eui_2010_2_38

11. Слободянюк О. М. Формування професійно-етичної компетентності майбутніх менеджерів економічного профілю у процесі вивчення суспільногуманітарних дисциплін : автореф. дис. ... канд. пед. наук : 13.00.04 / Нац. акад. пед. наук України, Ін-т вищ. освіти. Київ, 2017. 20 с.

12. Слободянюк А. В, Андрущенко Н. О. Психологія управління та конфліктологія : навч. посібник для практичних та семінарських занять. Вінниця : BНTУ, 2010. $120 \mathrm{c}$.

13. Степанюк Т. В. Социальные факторы формирования и развития управленческой культуры в межнациональных организациях : автореф. дис. канд. социол. наук, Москва, 2006. 20 с.

14. Теоретичні i методичні засади моделювання фахової компетентності керівників закладів освіти : монографія / Г. В. Єльникова [та ін.] ; за ред.. Г. В. Слькової. Київ; Чернівці : Книги - XXI, 2010. 460 с.

15. Pet'ko Lyudmila. Developing students' creativity in conditions of university // Research: tendencies and prospects: Collection of scientific articles. - Editorial Arane, S.A. de C.V., Mexico City, Mexico, 2017. P. 272-276.

16. Bodnarchuk O., Bodnarchuk O., Ersozoglu R., Kanishevska L., Pet'ko L., Turchynova G. \& Vyshnivska N. Model of Entrepreneurial Corporate Education and Prospects of Professional Development of Managers in Ukraine. Journal of Entrepreneurship Education. 2019. No 22(2).

17. Sabat N., Ersozoglu R, Kanishevska L., Pet'ko L., Spivak Yar., Turchynova G., Chernukha N. Staff development as a condition for sustainable development entrepreneurship. Journal of Entrepreneurship Education (JEI). USA. Special Issue (March-2019) "Entrepreneurship : Investment and Innovation". 2019. Vol. 22. Pp. 1-7. 


\title{
Formation and Development of Interest in Music in Beginner Pupils in the Process of Learning to Play the Piano
}

\author{
Zabolotnia Nina \\ Honored Worker of Culture of Ukraine \\ Piano teacher-supervisor at Revutsky Children's Arts School No. 5 in Kyiv \\ (Kyiv, Ukraine)
}

\begin{abstract}
Presented a variety of methodological techniques at the first stages of learning to play the piano in order to form and consolidate interest at the piano lessons. Purely practical approaches to solving this problem that were tested in the process of real work with children of primary school age are offered. The main idea is the need for maximum approximation of learning to play a musical instrument to the types of creative activity familiar to a child. This is the main guarantee of the most complete manifestation of the pupil's creative abilities and their subsequent development. Given specific examples that facilitate the perception of the teacher's instructions, encourage the child to work independently, meaningfully elaborate musical works, and develop a desire to communicate with music. An interesting and original know-how is music comparison with wildlife (Such a relationship contributes to the natural feeling of the phrase, the naturalness of intonation, and differentiated sound extraction). The important role of teacher's personality, his ability to creating an atmosphere of true creativity far from the mechanical fulfillment of his instructions at the lesson is emphasized. Work with pupils should be based on "child-centeredness" principle in the broadest and best sense of the word.
\end{abstract}

Key words: Piano teacher, creative activity, learning to play the piano, beginner pupils, interest.

Актуальність дослідження. У сучасних умовах, коли на дітей обвалюється шквал різноманітної, далеко не завжди корисної, а іноді просто шкідливої інформації, коли чи не в кожній родині є планшети, ноутбуки, смартфони тощо, тема виховання інтересу та любові до справжнього мистецтва стає надзвичайно актуальною. Адже зараз, на жаль, відбувається суттєва зміна ціннісних орієнтацій дітей: зростання престижу матеріальних статків, зменшення ваги моральних, етичних та інтелектуальних чинників, швидкими темпами руйнується емоційна складова як в структурі особистості, так і в суспільному бутті в цілому. Тим важливішими $є$ спроби викладачів-практиків узагальнити та розповсюдити свій досвід виховання свідомого інтересу дітей до занять музикою, зокрема в класі фортепіано.

Виклад основного матеріалу. Практично кожний із викладачів-піаністів стикався у своїй педагогічній діяльності з цікавим, але, водночас, неприємним феноменом, - коли дитина приходить до школи мистецтв із великим бажанням, біжить на уроки в піднесеному настрої, але вже через 2-3 роки ми спостерігаємо прямо протилежну картину: в’ялість, безініціативність, байдужість і навіть бажання зовсім припинити 
заняття музикою. На практиці це означає, що інтерес зберігається до тих пір, поки заняття на фортепіано сприймаються як нова іграшка, і перші ж труднощі породжують спочатку байдужість, а потім і повне несприйняття навчання гри на фортепіано, через що, питання збереження та підсилення інтересу до занять музикою залишається відкритим і потребує зосередженого аналізу та опрацювання.

Численні методики викладання гри на фортепіано, які існують на сьогоднішній день, здебільшого мають на меті виховання суто професійних якостей юних піаністів, в них суттєво бракує конкретних рекомендацій щодо розвитку та стимулювання музичних інтересів у дітей, які навчаються в мистецьких школах. Адже не є таємницею, що викладачі однаково займаються 3 усіма учнями, намагаючись систематично прищеплювати професійні піаністичні навички тим, для кого значно важливішим було би отримати більш елементарні уміння, зробити акцент на розвиток слухових та загально музичних даних, знайомстві з музичною літературою. Основною метою, яку ставить перед початковою ланкою мистецької освіти суспільство, є виховання грамотного вмотивованого слухача, достатньо освіченого аматора, людину, для якої світ музики не чужий, в якої $\epsilon$ потреба в систематичному спілкуванні 3 музичним мистецтвом [6; 7; 8;9].

На нашу думку, найбільш обгрунтованими та перспективними є твердження, які підкреслюють у даному питанні, емоційний компонент. «Мистецтво $є$ специфічною формою відтворення дійсності, а пізнання мистецтва є особливим видом пізнання, що потребує іншого, емоційного мислення...»- зазначав видатний психолог Л. Виготський [2]. Один з найвідоміших педагогів-музикантів Д. Кабалевський писав: «Ми ні на мить не повинні забувати про головне завдання: зацікавити дітей музикою, емоційно захопити їх, «заразити» своєю любов’ ю до музики [4]. Якщо хочете, це навіть не завдання, а, як говорив К. Станіславський, надзавдання всієї музично-виховної роботи 3 дітьми. Інтерес до музики, захоплення музикою, любов до неї - неодмінна умова для того, щоб вона широко розкрила й подарувала дітям свою красу».

Якщо таким чином розглядати інтерес, то стає зрозумілим, що саме емоційна складова не дає інтересу згасати, а навпаки - породжує нові інтереси, але вже на більш високому рівні. Процес музичного пізнання має бути пов’язаним з почуттям радості, здивування, захоплення, задоволення від спілкування зі світом музики. Інтерес - це 
потужна позитивна емоція, що мотивує навчання, самовдосконалення, розвиток творчих прагнень.

Зазвичай багато фахівців рекомендують проводити заняття 3 початківцями в ігровій формі. Цей прийом безперечно дає позитивний результат, але лише протягом обмеженого часу. Адже і в цьому випадку інтерес зникає досить швидко, тому що за таких умов учень частіше за все виступає в ролі пасивного споживача ігрового дійства. Заняття не обов’язково мають носити суто розважальний характер, не повинні перетворюватись на «цирк». Адже тоді, йдучи на урок, дитина настроюватиме себе на легковажну та грайливу хвилю. Завдання справжнього вчителя - якомога повніше використати вікові психологічні особливості учня, зробити його повноцінним співучасником пізнавально-творчого процесу. Дитина повинна розуміти, що справа, якою вона займається, є серйозною, потребує певних зусиль, зосередженості та наполегливості. Звичайно, такий підхід має тісно співіснувати зі створенням на уроці емоційного фону активної зацікавленості.

Узагальнення багаторічного досвіду дозволяє зробити висновок, що основне завдання викладача-піаніста - якомога більше наблизити процес занять на фортепіано до звичних для дитини вікових видів діяльності.

Перш за все, ніж приступити до вивчення прийомів гри на інструменті, учень повинен оволодіти мовою музики, полюбити ії. Основним видом діяльності маленького музиканта на самому початку навчання мають бути не спроби виконавства на фортепіано, а знайомство з музикою у широкому розумінні цього слова.

Зазначимо, що ефективно спрацьовує запропоноване вчителем уявлення про музику як про живу істоту. Особливо, якщо викладач відразу продемонструє докази того, що музика є явищем живої природи. Разом 3 дитиною неважко з'ясувати, що музика має практично усі ознаки живих істот: наявність серцебиття, дихання, зміни настрою, здатність рухатись в різних темпах і тому подібне. Потім викладач може проілюструвати ці ознаки на яскравих, показових невеличких музичних прикладах. Наприклад, чітко простежити «серцебиття» в творах танцювального характеру (варто продемонструвати це на музичному прикладі, дещо перебільшено підкреслюючи сильні долі), широке «дихання» почути в п’єсі «Бабак» Л. Бетховена, інших творах вокальної 
природи, відслідкувати співставлення мажора та мінора (тобто зміни настрою) в творах «Весело-сумно» та «До Елізи» Л. Бетховена, українських народних піснях тощо.

Треба сказати, що парадоксальне на перший погляд твердження про приналежність музики до світу живої природи довело свою ефективність та значущість не тільки для початківців. Спираючись на цю тезу, як правило, можна вибудовувати в подальшому і звуковидобування, і відчуття фрази, і роботу над динамікою твору. Коли справа доходить до безпосередньої гри на інструменті та постає питання якості звуковидобування, знову в пригоді стає відчуття музики як живої істоти. Якщо рояль вдарити прямолінійно та грубо - він «закричить», звук буде різким, неприємним. Дитина добре розуміє це твердження. Тому вона поступово звикає до акуратного, прицільного, проникливого дотику до інструменту. Звичайно, коли дитина дорослішає, вона розуміє умовність такого

підходу до музики, але звичка до дбайливого ставлення залишається.

На початковому етапі навчання дуже важливими є свідоме оволодіння клавіатурою фортепіано, вільне відчуття розташування регістрів, знання тембрального забарвлення різних октав. Надзвичайно важливим $\epsilon$ зв'язок музичної мови 3 вербальною. Дітям набагато простіше та цікавіше грати музичні приклади, які мають підтекстовку. Це значно полегшує відчуття фрази, допомагає визначити кульмінацію, зрозуміти чергування сильних і слабких долей. До речі, вводити поняття «кульмінація» доцільно з перших уроків, для початку спираючись на літературні приклади. Всі діти чудово розуміють, де є кульмінація в знайомих казках.

Одна з провідних українських викладачів-піаністів Н. Найдич [5] у своїй збірці «Будем учиться играть» весь теоретичний матеріал, адресований початківцям, виклала у віршованій формі, яку діти сприймають набагато краще, ніж звичайні прозові пояснення. Можна запропонувати учню і самому написати текст до виконуваного твору, хоча це досить непросте завдання і не всім учням під силу. Більш реальним завданням $\epsilon$ підбір назви до виконаної педагогом п`єси.

Також добре сприймаються дітьми порівняння руху музики вгору та вниз із рухом сходинками. Тут головне, щоб дитина відчувала саме рух ВГОРУ та ВНИЗ, а не праворуч та ліворуч. Вгору рухатись важче, тож людина витрачає більше енергії та зусиль, мимоволі рухається «на крещендо». Вниз - навпаки, звучання затихає, 
докладати зусиль не доводиться, сплеск енергії не потрібен. Звичайно, це - зовсім спрощене поняття про закономірності музичного розвитку, але на початковому етапі його використання можна вважати доцільним.

Додамо, що доречним є порівняння вербального речення з музичною фразою. На кінці речення ми, як правило, говоримо трішки тихіше. Це фізіологічно обумовлено. Тож і кінець фрази на інструменті здебільшого (хоча і не завжди) затихає, неначе «видихається».

Для чіткого усвідомлення поняття сильної та слабкої долі доцільно використовувати такий прийом: попросити учня вимовити будь-яке слово без наголосу. Звісно, після кількох невдалих спроб учень розуміє, що це абсолютно неможливо. Тож для дитини стає зрозумілою необхідність відчуття сильної долі як неодмінного атрибуту самого існування музики.

«Запалити, захопити дитину бажанням оволодіти музичною мовою найголовніше 3 найперших завдань педагога», - вважала видатний педагог А. Д. Артоболевська [1].

Під час знайомства $з$ написанням нот слід пам'ятати прості, але важливі речі. Значна частина початківців вважає, що перша лінійка - верхня. Як не дивно, з цим помилковим твердженням іноді доводиться стикатися і в більш старших класах. Тут в пригоді стане порівняння нотного стану з будинком: адже поверхи ми рахуємо, починаючи з нижнього.

Під час розбору нотного тексту важливо, щоб зорове сприйняття було тісно пов’ язане з тактильними відчуттями. Потрібно, щоб учень зрозумів, що нотки, які «злиплись» на нотному стані та нагадують бантик, на клавіатурі знаходяться поруч. А ті, що вишикувались в акорді, як дитяча піраміда, одна на одній без проміжків, щільно, завжди розташовані на клавіатурі через одну клавішу. Задля полегшення читання нот 3 листа можна використовувати такий прийом: малюємо нотний стан не з 5 лінійок, а 36 або 7. Розташовуємо на ньому ноти та довільно оголошуємо назву першої ноти. Учень змушений читати цей нотний текст, виключно виходячи з графічного зображення. Тобто, на перший план виступає не назва нот, а розташування їх одна відносно іншої. Як показав досвід, цей метод добре спрацьовує, особливо в 2-3 класах. Великий ентузіазм викликає в учнів наявність «кишенькового» нотного стану, коли п’ять пальців 
на руці виконують роль п'яти лінійок, на яких пишуться ноти. Діти охоче показують розташування нот на власній долоні та пальчиках, до того ж це корисно для швидкого орієнтування в написанні нот.

Коли починається найвідповідальніший та найскладніший процес постановки рук, треба, як не парадоксально, якомога менше концентрувати увагу дитини саме на цьому процесі. Це дозволяє уникати скутості та неприродності в постановці рук, вкорінення негативних відчуттів, особливо якщо викладач має погану звичку трясти зап’ястками учня в повітрі, жорстко хапати дитину за лікті і тому подібне. В початковій постановці рук головне - свобідне почуття ваги рук, що переноситься з пальця на палець. При цьому необхідно коригувати швидкість падіння рук на клавіатуру, щоб уникнути грубого прямолінійного звуковидобування. Крім того, учень має розуміти необхідність та зручність напівзакругленої форми пальців, які повинні формувати міцний, але пружний каркас долоні.

Усім знайома вправа переносу рук по октавах. Однак вона має один суттєвий недолік: руки падають занадто швидко, звук виходить агресивним, негарним, жорстким. Хороший результат показують діти, руки яких викладач «перетворив» на сміливих парашутистів. Вони спускаються на землю повільніше, форма долоні абсолютно копіює купол парашута, та й приземляється парашутист прицільно й акуратно на ноги (пальці), стежачи, щоб ненароком їх не поламати.

Надзвичайно важливими складовими, що сприяють підтриманню інтересу до занять є максимальне розширення репертуару, якомога більша кількість задіяних в роботі творів, гра в ансамблі, читання незнайомих творів $з$ листа.

Не варто вимагати від учня досконалого виконання всіх творів, які є в його репертуарі. Важливо прищепити дитині прагнення познайомитись 3 якомога більшою кількістю різноманітних п’єс. Адже важко уявити собі, яким би був інтерес учня до уроку рідної мови, якби протягом семестру дитина вивчила б тільки 2-3 вірші або прочитала 1 або 2 оповідання!

У великій пригоді стає ансамблеве музикування. Проста та невибаглива мелодія, виконувана початківцем, звучить виразно і яскраво в супроводі гармоній партії secondo. Можна змінювати фактуру викладення другої партії, щоб учень зрозумів сутність та можливості різних видів музичної фактури. Важливо на першому етапі навчання значну 
частину дитячих пісеньок виконувати в ансамблі з педагогом. Користь від такого музикування, навіть суто психологічну, важко переоцінити. Адже творчим партнером дитини в даній ситуації виступає сам учитель, авторитет якого на початковому етапі навчання сумніву не підлягає. Розумний педагог зможе зробити так, що учень відчує себе артистом, рівним шанованому та любимому вчителю!

Не менш корисним є підбір на слух мелодій, які $є$ в репертуарі учня або знайомі дитині з телепередач чи просто з життєвого досвіду. Зокрема можна практикувати гру уривків з таких відомих українських народних пісень, як «Їхав козак за Дунай», «Дівка в сінях стояла», «Ой лопнув обруч», «Перстень» та ін. від усіх білих та чорних клавіш. Це привчає дитину не боятись гри на чорних клавішах. А розпочинати процес підбору на слух можна з аналізу простих мелодій (або їх фрагментів), знаходячи повторювані звуки, визначаючи ритмічний малюнок; допомагає аналіз інтервального складу мелодій (звичайно, в спрощеному вигляді), розуміння напрямку руху в пісеньці. Підбір на слух також породжує, а надалі й розвиває, відчуття тоніки. Така складова музичного виховання і досі залишається поза увагою значної частини викладачів. Хоча, йдучи навчатись музиці, дитина підсвідомо мріє навчитись грати знайомі твори без нотного тексту.

Питання репертуару - одне з найважливіших протягом усього періоду навчання. Від вдало підібраних для опрацювання творів багато в чому залежить ставлення учня до занять фортепіано в цілому. Чимало викладачів, яких не повністю влаштовують існуючі репертуарні збірки, вдаються до створення власних.

На наш погляд, привертає увагу серія «Забуті імена», що створена на факультеті мистецтв НПУ імені М. П. Драгоманова. До першої збірки серії увійшли легкі твори прекрасних українських композиторів В. Барвінського, С. Шевченка, М. Любарського, I. Віленського, П. Козицького, М. Скорульського.

Опора на національний репертуар дає завжди позитивний результат, тому що сприймається дитиною на глибинному, генетичному рівні.

Враховуючи психологічні особливості 6-7 річних дітей (вразливість, підвищену сприйнятливість, предметне мислення), корисно, по можливості, залучати до репертуару побільше творів з цікавими назвами. Наприклад, в навчальному посібнику для малят «Хочу грати на роялі» відомий український педагог Наталія Гриднєва [3] 
використовує твори та вправи з такими назвами: «По сходинках», «Веселі півтони», «Равлик», «Обережні кроки», «Зламана машина» та багато інших. Взагалі, на уроці має панувати атмосфера творчості в прямому смислі цього слова. Учень не повинен відчувати, що викладач вже десятки разів опрацьовував твори 3 іншими дітьми. Навпаки, вчитель має дивуватися разом з учнем, почувши цікаве співзвуччя, радіти кожному виразному мелодійному звороту. Кожен вчитель має бути трішки актором. Він ні в якому разі не може бути просто джерелом інформації для дитини - а повинен стати другом і навіть в якомусь розумінні колегою для маленького музиканта. Має щиро радіти найменшим успіхам дитини, заохочувати іiі до подальшого розвитку та вдосконалення, вчитись разом з нею.

Дуже корисною є гра, пов'язана зі зміною ролей - викладач та учень міняються місцями. Викладач навмисне виконує твір незграбно, 3 помилками, 3 алогічною динамікою. Завдання учня - почути недоречності та помилки, по можливості скоригувати їх. Ця ігрова модель надзвичайно активізує увагу дитини, підвищує іiі впевненість в своїх силах. Інший варіант, коли учень оцінює гру іншого учня та дає йому поради щодо покращення виконання твору. Цей варіант придатний для більш старших учнів.

Надзвичайно важливо виховати в учнів повагу та пієтет до виконуваних творів, привчати саме виконувати їх, а не просто програвати. Необхідно, щоб дитина розуміла, що вона має передати саму сутність твору, навіть найпростішого, заразити слухачів своїм інтересом до виконуваної п“єси, передати їм щире захоплення нею. 3 перших кроків маленький музикант повинен відчувати себе артистом, а не слухняним та безсловесним відтворювачем чиїхось настанов. Тоді він вчитиметься 3 більшим бажанням та натхненням.

Висновки. Отже, скільки учнів - стільки різних прийомів доводиться шукати викладачу, аби музика стала невід'ємною частиною життя дитини.

Подолання заакадемізованості навчального процесу, наближення навчання до природних видів діяльності дитини дозволить сформувати в неї позитивне ставлення до занять музикою. Своєю чергою, розумний і небайдужий викладач знайде необхідні методичні прийоми, здатні зберегти та примножити інтерес учня до навчання гри на фортепіано. Головне - відкинути зайві педагогічні амбіції, не займатися з дитиною 
безглуздим та безпредметним вишколом, а дотримуватись «дитиноцентризму» в найкращому та найширшому сенсі цього слова. Музика повинна зайняти в житті дитини важливу «нішу», яка нічим іншим бути зайнята просто не може.

\section{References}

1. Artobolevskaya A. D. The first meeting with music. Moscow: "Soviet composer", 1985. $101 \mathrm{p}$.

2. Vygotsky L. S. Questions of child psychology. Collection of works V. 4 T. Moscow: Pedagogy, 1984. 432 p.

3. Gridneva N. V. I want to play the piano. Kyiv: "Musical Ukraine", 2012.193 p. 319 p.

4. Kabalevsky D. B. How to tell children about music? Kyiv: "Musical Ukraine", 1981.

5. Naydich N. M. Let's learn to play. Kyiv: Optima, 2010. 48 p.

6. Pet'ko L. V. Lingvosociokulturnyj pidhid u vyvchenni anglomovnoyi novorichnoyi pisni «Jingle Bells» [Lingvosociocultural Approach to Teaching American New Year's Song «Jingle Bells»] // Topical issues of redagogy : Collective monograph. - Edizioni Magi, Roma, Italy, 2019. P. 31-57.

7. Pet'ko L. V. Shljahy formuvannja inshomovnoi' sociokul'turnoi' kompetencii' studentiv mystec'kyh special'nostej VNZ u procesi fahovoi' pidgotovky [The Ways of Formation of Foreign Language Socio-Cultural Competence of Students of Music-Pedagogical Specialties in Higher School in the Process of Professional Teaching]. Problemy pidgotovky suchasnogo vchytelja. 2012. Vol. 6. Part 3. Pp. 57-62.

8. Shcholokova Olga, Ding Yun. Pedagogical Principles of Young Pupils' Music Culture Formation in Piano Teaching Process. Intellectual Archive. 2015. Volume 4. No. 6 (November). Toronto : Shiny Word Corp., 2015. Pp. 160-169.

9. Zhang Jiangan. The methods on forming the worldview culture of future Music teachers in the process of piano learning. Intellectual Archive. Toronto: Shiny Word.Corp. (Canada). 2020. Vol. 9 (April/June). No. 2. Pp. 151-162.

DOI: https://doi.org/10.32370/IA_2020_06_18

Translation of the Title, Abstract and References to the Author's Language

\section{УДК 373.5.091.3:780.616.432}

Заболотня Н. М. Формування та розвиток інтересу до занять музикою в учнів-початківців у процесі навчання гри на фортепіано.

Розглянуто питання необхідності застосування різноманітних методичних прийомів на перших етапах навчання гри на фортепіано 3 метою формування та закріплення інтересу до занять. Пропонуються суто практичні підходи до вирішення цієї проблеми, які були опробувані у процесі реальної роботи з дітьми молодшого шкільного віку. Основною тезою є необхідність максимального наближення навчання гри на 
музичному інструменті до звичних дитині видів творчої діяльності, що головною запорукою якнайповнішого прояву творчих здібностей учня та їх подальшого розвитку. Також наведено конкретні приклади, які полегшують сприйняття вказівок педагога, спонукають дитину до самостійної роботи, осмисленого опрацювання музичних творів, розвивають бажання спілкуватися 3 музикою. Цікавим та оригінальним ноу- хау $є$ співставлення музики з явищами живої природи. Такий зв'язок сприяє природному відчуттю фрази, інтонації, диференційованому звуковидобуванню. Акцентується важлива роль особистості педагога, його вміння створити на уроці атмосферу справжньої творчості, далекої від механічного виконання його настанов. Робота 3 учнями має будуватись за принципом «дитиноцентризму» в найширшому та найкращому сенсі цього слова.

Ключові слова: учитель по класу фортепіано, креативність, навчання гри на фортепіано, учні-початківці, інтерес.

1. Арторература
А. Д. Первая встреча с музыкой. Москва : «Советский композитор», 1985. $101 \mathrm{c}$.

2. Выготский Л. С. Вопросы детской психологии. Собрание сочиненй в 4 т. Москва : Педагогика, 1984. 432 с.

3. Гриднєва Н. В. Хочу грати на роялі. Київ : «Музична Україна», 2012. 193 с.

4. Кабалевський Д. Б. Як розповідати дітям про музику?. Київ : «Музична Україна», $1981.319 \mathrm{c}$.

5. Найдич Н. М. Будем учиться играть. Київ : «Оптіма», 2010. 48 с.

6. Петько Л. В. Лінгвосоціокультурний підхід у вивченні англомовної новорічної пісні «Jingle Bells» // Topical issues of redagogy : Collective monograph. - Edizioni Magi, Roma, Italy, 2019. P. 31-57.

7. Петько Л.В. Шляхи формування іншомовної соціокультурної компетенції студентів мистецьких спеціальностей ВНЗ у процесі фахової підготовки. Проблеми підготовки сучасного вчителя: зб. наук. пр. Уманського держ. пед. ун-ту імені Павла Тичини. Умань : ПП Жовтий О.О., 2012. Випуск 6. Ч. 3. С. 57-62.

8. Shcholokova Olga, Ding Yun. Pedagogical Principles of Young Pupils' Music Culture Formation in Piano Teaching Process. Intellectual Archive. 2015. Volume 4. No. 6 (November). Toronto: Shiny Word Corp., 2015. Pp. 160-169.

9. Zhang Jiangan. The methods on forming the worldview culture of future Music teachers in the process of piano learning. Intellectual Archive. Toronto: Shiny Word.Corp. (Canada). 2020. Vol. 9 (April/June). No. 2. Pp. 151-162.

DOI: https://doi.org/10.32370/IA_2020_06_18 


\title{
The Development of Sociocultural Component in Professional Education of Future Navigators in the Fifties of the XXth Century
}

\author{
Penza Iryna \\ ORCID https://orcid.org/0000-0002-8984-188X \\ Postgraduate student \\ Municipal higher education institution "Kherson Academy of Continuing \\ Education" of Kherson Regional Council (city Kherson, Ukraine)
}

\begin{abstract}
The article is devoted to developing the socio-cultural component in professional education of future navigators in the 50s of the XXth century. Considered resolutions of the Central Committee of the CPSU (b) and the Central Committee of the CPSU, which influenced the teaching of disciplines that represent the socio-cultural component. Determined that during this period the leadership of party bodies was strengthened by scientific institutions of the republic, topics of friendship with people, Soviet patriotism, history of development of sociopolitical, philosophical and economic thought in Ukraine were obligatory for studying in higher and secondary special educational institutions. Described Russian socio-political thought and culture for the development of Ukrainian culture. It is concluded that since the educational institutions for training future navigators were subject to the regulations of the education sphere, and the development of the socio-cultural component of education is characterized by excessive politicization and ideology.

Key words: development, socio-cultural component of education, future navigators, social disciplines, resolution, educational institutions.

Актуальність дослідження. Питання розвитку соціокультурної складової професійної освіти майбутніх судноводіїв $€$ надзвичайно актуальним у зв'язку 3 інтеграцією України до Свропейського союзу та необхідністю вивчення, освоєння та використання світових водних ресурсів. Історико-педагогічні пошуки дозволяють розкрити характер еволюції знань про досліджувану проблему, простежити модифікації з досліджуваного питання та визначити його вплив на сучасний стан педагогічної науки.

Попередні статті ми присвятили визначенню поняття «соціокультурної складової освіти майбутніх судноводіїв», студіюванню категорійно-понятійного апарату проблеми розвитку соціокультурної складової професійної освіти майбутніх судноводіїв, кореляції понять «соціокультурна складова освіти» та «соціокультурна компетентність» $[1 ; 6 ; 14]$. Таким чином було визначено, що «соціокультурна складова професійної освіти майбутніх судноводіїв» - це змістовна компонента їх професійної освіти, що поєднує знання, вміння та навички, які допомагають ефективно здійснювати професійну діяльність з урахуванням суспільних, мисленнєвих, соціальних, культурних,
\end{abstract}


ціннісних факторів та вести ефективну діяльність у полікультурному середовищі, що включає знання обов'язків із несення вахти на містку, з радіослужби, обов'язків представника командного складу багатомовного екіпажу тощо. А «розвиток соціокультурної складової професійної освіти майбутніх судноводіїв» як частина змісту освіти судноводіїв - це процес, у результаті якого відбуваються якісні зміни, зростає ступінь освіченості, культурності, здібностей та потенціалу, професійної компетентності представників палубної команди, передбаченої Міжнародною конвенцією про підготовку і дипломування моряків та несення вахти $[1 ; 6 ; 14]$.

Значна кількість вітчизняних вчених наголошує на актуальності соціокультурної складової освіти, серед них Л. Вольнова, О. Касаткіна, А. Клебанська, О. Коломинова, М. Максимець, А. Мурзіна, Л. Петько [8; 9; 18]. Дане питання у сфері морської освіти висвітлено у працях М. Бабишеної, Н. Бобришевої, С. Козак, Л. Ліпшиць, Н. Слюсаренко [14; 15; 16; 19], О. Фролової та ін. Своєю чергою, Л. Ліпшиць та Н. Слюсаренко зазначають, що соціокультурна компетентність дозволяє курсантам усвідомлювати різницю між культурами, долати соціокультурні відмінності [14, с. 39], а формування соціокультурної компетентності відбувається у процесі вивчення дисциплін соціально-гуманітарного циклу [16, с. 21].

Проте аналіз історико-педагогічних робіт свідчить, що не існує комплексного вичерпного дослідження розвитку соціокультурної складової професійної освіти майбутніх судноводіїв у 50-70-ті pр. ХХ століття, тому дане дослідження є актуальним, а його результати можуть бути використані для характеристики розвитку морської освіти у визначений хронологічний відрізок та для вдосконалення підготовки судноводіїв сьогодні.

Виклад основного матеріалу. У 50-ті рр. ХХ ст. на землях, не так давно визволених від фашистських загарбників, почалась робота з відновлення зруйнованого господарства. Значна увага приділялась діяльності морського транспорту та перспективам подальшого розвитку флоту. Основними характеристиками освіти даного періоду є доступність для всіх верств населення, політехнізація, зв'язок з політикою, спрямованість на формування людини з глибокими комуністичними переконаннями.

Науки суспільно-гуманітарного циклу (політична економія, діалектичний та історичний матеріалізм, історія СРСР/КПРС, філософія, мови, література) 
репрезентують соціокультурну складову освіти. У досліджуваний відтинок часу вимоги до їхнього викладання змінювались у результаті прийняття нормативно-правових актів, серед яких: Постанова ЦК ВКП (б) від 06.08.1951 р. «Про заходи щодо покращення викладання суспільних наук у вищих навчальних закладах» [3, с. 245-249] та Постанова ЦК КПРС від 18.06.1956 р. «Про викладання у вищих навчальних закладах політичної економії, діалектичного та історичного матеріалізму та історії КПРС» [7, с. 96].

У Постанові ЦК ВКП (б) від 06. 08. 1951 р. «Про заходи щодо покращення викладання суспільних наук у вищих навчальних закладах» зосереджувалась увага на необхідності виховання у студентів усвідомленого та творчого відношення до вивчення теорії, зв'язку викладання суспільних наук з практикою, залученні значного матеріалу 3 області політичного, господарського, культурного життя під час їх вивчення. Згідно 3 даною постановою розширювалась підготовка викладачів суспільних дисциплін, 3 1951 р. збільшувався набір до аспірантури вузів з марксизму-ленінізму - 250 чоловік, політекономії - 50, філософії - 50 [3, с. 245-249].

На пленумах ЦК КП/б/У наголошувалось на необхідності посилити керівництво партійних органів науковими закладами республіки, спрямувати їхню увагу на розробку проблем, пов'язаних із завданнями комуністичного будівництва. Особлива увага приділялась посиленню роботи інститутів суспільних наук, підвищенню кваліфікації наукових співробітників, їх вихованню у дусі непримиренності до недоліків, приятелізму, безпринципності. Партія ставила завдання перед науковими кадрами створити праці, які б висвітлювали питання дружби народів, радянського патріотизму, історії розвитку суспільно-політичної, філософської та економічної думки в Україні, корисного впливу російської суспільно-політичної думки та культури на розвиток української культури, історичної дружби українського та російського народів [11, c. 34-35].

Робота з архівними джерелами дає підстави констатувати високі вимоги й до викладачів середніх спеціальних морських закладів. У річних звітах Херсонського морехідного училища Міністерства морського флоту часто надавалась характеристика окремих викладачів, взаємовідвідування занять відбувалось не лише з метою обміну методичними прийомами викладання, але й задля перевірки чи не допускає викладач відхилень від партійних позицій. Саме суспільні дисципліни формували не просто 
судноводія, але громадянина з комуністичними переконаннями. Наприклад, викладача історії народів СРСР Херсонського морехідного училища Міністерства морського флоту (ММФ) у 1952 р. звільнили з посади, визнавши недостатньо кваліфікованим, оскільки, викладаючи дисципліну, він «допускав відрив історії від сучасності, не проводив чіткого пояснення історичних фактів 3 партійних позицій» [4, с. 25]. Викладачу літератури Одеського морехідного училища під час взаємовідвідування занять зробили зауваження з приводу розбору релігійності одного з персонажів п'єси Островського «Гроза» без приділення уваги антирелігійній пропаганді, проте, відзначили позитивним наведення прикладу про В. Леніна, який любив цитувати Островського та розповідати про світове значення драматурга [2, с. 41].

Попри значну увагу до суспільних дисциплін, які репрезентують соціокультурну складову професійної освіти майбутніх судноводіїв, у даний період існували недоліки, пов'язані з їхнім викладанням, що засвідчено в архівних джерелах: книжне засвоєння студентами марксизму-ленінізму, елементи школярства, догматизм, начотництво. Програми з суспільних наук в основному орієнтували на пасивні форми роботи зі студентами. Більшість учбового часу відводилась на лекції, які повторювали літературу 3 цих питань, доступну для самостійного вивчення студентами. Наприклад, з курсу політичної економії у технічних вузах зі 150 годин - 84 години виділялось на читання лекцій, з діалектичного та історичного матеріалізму з 90 годин - лекційних 50. Теми лекцій дублювали розділи підручників та учбових посібників, більшість семінарських занять повторювали зміст лекцій, майже не поглиблюючи та не розвиваючи їх [12, c. 155].

Згідно з постановою ЦК КПРС «Про викладання у вищих навчальних закладах політичної економії, діалектичного та історичного матеріалізму та історії КПРС» від 18.06.1956 р. у всіх вузах країни з 1956-1957 н.р. вводились перераховані дисципліни у вигляді самостійних курсів. Подальші реформи спрямовувались на зменшення догматизму у викладанні матеріалу, що сприяло підвищенню якості викладання [7].

Викладачі середніх спеціальних морських навчальних закладів об'єднувались у предметні та циклові комісії з метою вдосконалення навчальної та виховної роботи 3 одного або декількох споріднених предметів. 
Проведений аналіз протоколів засідань, планів роботи циклових комісій з історії, російської мови та літератури; пізніше циклових комісій з історії, суспільствознавства та літератури; циклових комісій з англійської мови дає підстави стверджувати, що головними заходами, передбаченими на навчальний рік для всіх циклових комісій були: 1) слідкувати за новинками політичної та спеціальної літератури 3 предметів; 2) готувати та проводити з курсантами доповіді на теми про авторитет радянської літератури, культури, цінностей тощо; 3) регулярно читати політичні та методичні журнали; проводити з курсантами політінформації (часто їх влаштовували самі курсанти під керівництвом викладача); 5) вивчати твори класиків марксизму-ленінізму; 6) регулярно підвищувати ідейно-теоретичний рівень та ділову кваліфікацію викладача $[10 ; 13]$.

Серед головних завдань, на здійснення яких спрямовувалась навчальнометодична робота були: 1) прищеплення курсантам марксистсько-ленінського світогляду, виховання патріотизму, любові до батьківщини, чесності, мужності, стійкості у боротьбі з труднощами та безмежної відданості справі Леніна-Сталіна; 2) виховання у курсантів любові до власної спеціальності та відмінного оволодіння знаннями зі спеціальності; 3) виховання у курсантів воїнської та трудової дисципліни; 4) неухильне підвищення якості викладання (викладання на високому ідейнотеоретичному рівні у розвитку науки і техніки); 5) підготовка висококваліфікованих фізично здорових, морально-стійких кадрів для морського та воєнно-морського флоту $[4$, c. $40 ; 5$, c. 2$]$.

Висновки. Розвиток соціокультурної складової професійної освіти майбутніх судноводіїв у 50-ті pp. XX ст. позначений впливом партійних органів та характеризується тенденціями посилення радянського патріотизму i формування суспільно-корисних громадян. Середні спеціальні та вищі навчальні заклади 3 підготовки морських фахівців підпорядковувались нормативно-правовим актам освітньої галузі, спрямованим на покращення викладання суспільних дисциплін та ідеологічну підготовку молоді. Поступово збільшувалась частка заідеологізованих предметів, посиленої практики набувало проведення з курсантами політінформацій, бесід про авторитет радянської літератури, культури, цінностей тощо, саме дисципліни соціокультурного спрямування якнайширше висвітлювали дану тематику. 


\section{References}

1. Verbii I. V. Vyznachennia poniattia «sotsiokulturna skladova osvity maibutnikh sudnovodiiv» [Definition of the concept "socio-cultural component of education of future navigators"]. Pedahohichnyi almanakh: zbirnyk naukovykh prats. Kherson, 2018. Issue 38. P. 89-95.

2. Hodovoi otchet o rabote OMU za 1951-1952 uch. hod [Annual report on the work of OMC for 1951-1952 academic year]. Derzhavnyi arkhiv Odeskoi oblasti. F. R-2018. Op. 4. Spr. 54. 96 ark.

3. KPSS $v$ rezoliutsyiakh y reshenyiakh siezdov, konferentsyi y plenumov TsK (1898-1988): $v 16 t$. [CPSU in resolutions and decisions of congresses, conferences and plenums of the Central Committee (1898-1988): in 16 v.]. / pod. obshch. red. A. H. Ehorova, K.M. Boholiubova. 9-e izd., dop. y yspr. Moskva: In-t marksyzma-leninizma pri TsK KPSS, 1985. Vol. 8: 1946-1955. 584 p.

4. Otchet za 1951-1952 uchebnyi hod Khersonskoho morekhodnoho uchylyshcha Mynysterstva Morskoho flota [Report for the 1951-1952 academic year of Kherson Maritime College of the Ministry of the Navy.]. Derzharkhiv Khersonskoi obl. (Derzhavnyi arkhiv Khersonskoi oblasti). F. R-472. Op. 4. Spr. 28. 255 ark.

5. Otchet o rabote uchylyshcha za 1953-1954 uchebnyi hod [Annual report on the work of college for 1953-1954 academic year]. Derzharkhiv Khersonskoi obl. (Derzhavnyi arkhiv Khersonskoi oblasti). F. R-472. Op. 4. Spr. 40.84 ark.

6. Penza I. V. Katehoriino-poniatiinyi aparat problemy rozvytku sotsiokulturnoi skladovoi profesiinoi osvity maibutnikh sudnovodiiv [Categorical-conceptual apparatus of the problem of development of socio-cultural component of professional education of future navigators] // Aktualni problemy suchasnoi pedahohichnoi nauky: materialy vseukrainskoi naukovo-praktychnoi konferentsii (Drohobych, 9-10 kvitnia 2020 r.). Drohobych: Redaktsiino-vydavnychyi viddil Drohobytskoho ped. un-tu im. I. Franka, 2020. Pp. 160-163.

7. Petrushenko A. D, Rybakova V. M. Reformyrovanye systemy obrazovanyia $v$ SSSR $v$ peryod «ottepely» (1953-1964 hh.) [Reforming the education system in the USSR during the "thaw" (1953-1964)]. Trudy molodykh uchenykh: sbornyk materyalov y dokladov. Moskva, 2010. Pp. 93-97.

8. Petko L. V. Yednist navchannia $i$ vykhovannia $u$ formuvanni profesiino oriientovanoho inshomovnoho navchalnoho seredovyshcha $v$ umovakh universytetu [Unity of teaching and upbringing in the formation of professionally oriented foreign language learning environment at conditions of university] : monohrafiia. Kyiv : Talkom, 2017. 337 p. ; bibliohr.

9. Pet'ko L.V. Imperativ globalizatsiynyh perspektyv - formuvannya profesiyno spryamovanogo inshomovnogo navchalnogo seredovischa $v$ umovah universitetu [The imperative of globalization perspectives - the forming of the professionally directed foreign language educational environment in the conditions of university]. Pedagogika vyshhoi' ta seredn'oi' shkoly: zb.nauk.prac'. Issue 41. Kryvyj Rig : Drukarnja Romana Kozlova, 2014. Pp. 254-261.

10. Plan raboty, protokoly zasedanyi y otchet tsyklovoi metodycheskoi komyssyy anhlyiskoho yazyka [Work plan, minutes of meetings and report of the cycle methodical 
commission of the English language]. Derzharkhiv Khersonskoi obl. F. R-472. Op. 4. Spr. 126. 112 ark.

11. Postanovlenyia plenuma $T s K K P / b / U$ (oryhynaly) [Resolutions of the plenum of the Central Committee of the CP / b / U (originals)]. Tsentralnyi derzhavnyi arkhiv hromadskykh obiednan. F. 1. Op. 1. Spr. 978.92 ark.

12. Protokoly No 1-4, stenohramy ta inshi dokumenty zasidan kolehii MVO URSR [Protocols No 1-4, transcripts and other documents of meetings of the board of MVO of the USSR]. Tsentralnyi derzhavnyi arkhiv vyshchykh orhaniv vlady ta upravlinnia Ukrainy. F. R4621. Op. 1. Spr. 140. 228 ark.

13. Protokoly zasedanyi, plany raboty tsyklovoi metodycheskoi komyssyy ystoryy, russkoho yazyka y lyteratury [Minutes of meetings, work plans of the cycle methodical commission of history, Russian language and literature]. Derzharkhiv Khersonskoi obl. F. R472. Op. 4. Spr. 123. 43 ark.

14. Slyusarenko N. V., Verbyi Y. V. Korreliatsyia poniatyi «sotsyokulturnaia sostavliaiushchaia obrazovanyia»y «sotsyokulturnaia kompetentnost» [Correlation of the concepts "socio-cultural component of education" and "socio-cultural competence"]. Doklady Kazakhskoi akadem. obrazovanyia. 2018. No 3. Pp. 124-131.

15. Slyusarenko N., Lypshyts L. Osobennosty sotsyalno-humanytarnoi podhotovky budushchykh sudovodytelei kak faktora formyrovanyia ykh sotsyokulturnoi kompetentnosty. [Features of social and humanitarian training of future navigators as a factor in the formation of their socio-cultural competence]. Obrazovanye v 21-om veke. Erevan: EHU Press, 2019. No 2(2). Pp. 38-45.

16. Slyusarenko N. V., Lypshyts L. V. Strukturnye komponenty modely formyrovanyia sotsyokulturnoi kompetentnosty budushchykh sudovodytelei mezhdunarodnykh reisov [Structural components of the formation model of socio-cultural competence of future navigators in international voyages]. Doklady Kazakhskoi akademyy obrazovanyia. 2017. No 1. Pp. 21-30.

17. Turchynova H. V. Psykholinhvistychni peredumovy ovolodinnia inozemnoiu movoiu dlia spetsialnykh tsilei [Psycholinguistic prerequisites for mastering a foreign language for special purposes]. Naukovi zapysky. Kyiv : Vyd-vo NPU imeni M. P. Drahomanova, 2011. Issue LXXXXVIII (98). Pp. 201-207.

18. Pet'ko Lyudmila. About socio-culturological content in teaching subjects // Development strategy of science and education: Collection of scientific articles. - Fidelite editions, Namur, Belgique, 2017. P. 316-319.

19. Slyusarenko N., Soter M. The Webquest as a Means of Improving the Efficiency of Students' Foreign Language Training of Ukrainian Technical Institutions of Higher Education (Beginning of the $21^{\text {st }}$ Century). Intellectual Archive. Toronto: Shiny Word.Corp. (Canada). 2020. Vol. 9 (April/June). No. 2. Pp. 94-104.

DOI: https://doi.org/10.32370/IA_2020_06_13

Translation of the Title, Abstract and References to the Author's Language 


\section{УДК 378.1}

Пенза Ірина. Розвиток соціокультурної складової професійної освіти майбутніх судноводіїв у 50-ті роки $X X$ століття.

Стаття присвячена розвитку соціокультурної складової професійної освіти майбутніх судноводіїв у 50-ті роки XX століття. Розглянуто постанови ЦК ВКП (б) та ЦК КПРС, які впливали на викладання дисциплін, що представляють соціокультурну складову. Визначено, що у даний період посилювалось керівництво партійних органів науковими закладами республіки, для вивчення у вищих та середніх спеціальних навчальних закладах обов'язковими були теми про дружбу народів, радянський патріотизм, історію розвитку суспільно-політичної, філософської та економічної думки в Україні, вплив російської суспільно-політичної думки та культури на розвиток української культури. Зроблено висновок, що оскільки навчальні заклади з підготовки майбутніх судноводіїв підпорядковувались нормативно-правовим актам освітньої галузі, розвиток соціокультурної складової освіти позначений надмірною політизацією та заідеологізованістю.

Ключові слова: розвиток, соціокультурна складова освіти, майбутні судноводії, суспільні дисципліни, постанова, навчальні заклади.

\section{Література}

1. Вербій І. В. Визначення поняття «соціокультурна складова освіти майбутніх судноводіїв» Педагогічний альманах: збірник наукових праць. 2018. Вип. 38. С. 89-95.

2. Годовой отчет о работе ОМУ за 1951-1952 уч. год. Державний архів Одеської області. Ф. Р-2018. Оп. 4. Спр. 54. 96 арк.

3. КПСС в резолюциях и решениях съездов, конференций и пленумов ЦК (1898-1988): в 16 т. / под. общ. ред. А. Г. Егорова, К. М. Боголюбова. 9-е изд., доп. и испр. Москва : Ин-т марксизма-ленинизма при ЦК КПСС, 1985. Том 8: 1946-1955. $584 \mathrm{c}$.

4. Отчет за 1951/52 уч. год Херсонского мореходного училища Министерства Морского флота. Держархів Херсонської обл. (Держсавний архів Херсонської області). Ф. Р-472. Оп. 4. Спр. 28. 255 арк.

5. Отчет о работе училища за 1953/54 уч. год. Держархів Херсонської обл. (Державний архів Херсонської області). Ф. Р-472. Оп. 4. Спр. 40. 84 арк.

6. Пенза I. В. Категорійно-понятійний апарат проблеми розвитку соціокультурної складової професійної освіти майбутніх судноводіїв. Актуальні проблеми сучасної педагогічної науки: матеріали всеукраїнської науково-практичної конференції (Дрогобич, 9-10 квітня 2020 р.). Дрогобич: Редакційно-вид. відділ Дрогобицького пед. ун-ту ім. І. Франка, 2020. С. 160-163.

7. Петрушенко А. Д, Рыбакова В. М. Реформирование системы образования в СССР в период «оттепели» (1953-1964 гг.). Труды молодых ученых: сборник материалов и докладов. Москва, 2010. С. 93-97.

8. Петько Л. В. Єдність навчання $\mathrm{i}$ виховання у формуванні професійно орієнтованого іншомовного навчального середовища в умовах університету : монографія. Київ : Талком, 2017. 337 с. 
9. Петько Л. В. Імператив глобалізаційних перспектив - формування професійно спрямованого іншомовного навчального середовища в умовах університету. Педагогіка вищої та середньої школи: зб.наук.праць ; за ред. З.П.Бакум. Криворізький педагогічний інститут ДВНЗ «Криворізький національний університет». Вип. 41. Кривий Ріг : Друкарня Романа Козлова, 2014. С. 254-261.

10. План работы, протоколы заседаний и отчет цикловой методической комиссии английского языка. Держархів Херсонської обл. Ф. Р-472. Оп. 4. Спр. 126. 112 арк.

11. Постановления пленума ЦК КП/б/У (оригиналы). Центральний державний архів громадських об'єднань. Ф. 1. ОП. 1. Спр. 978.92 арк.

12. Протоколи №№1-4, стенограми та інші документи засідань колегії МВО УРСР. Центральний державний архів вищих органів влади та управління Украӥни. Ф. Р4621. Оп. 1. Спр. 140. 228 арк.

13. Протоколы заседаний, планы работы цикловой методической комиссии истории, русского языка и литературы. Держархів Херсонської обл. Ф. Р-472. Оп. 4. Спр. 123. 43 арк.,

14. Слюсаренко Н. В., Вербий И. В. Корреляция понятий «социокультурная составляющая образования» и «социокультурная компетентность». Доклады Казахской академии образования. 2018. № 3. С. 124-131.

15. Слюсаренко Н., Липшиц Л. Особенности социально-гуманитарной подготовки будущих судоводителей как фактора формирования их социокультурной компетентности. Образование в 21-ом веке: международный научно-методический рецензированный журнал. Ереван: ЕГУ Пресс, 2019. № 2(2). С. 38-45.

16. Слюсаренко Н. В., Липшиц Л. В. Структурные компоненты модели формирования социокультурной компетентности будущих судоводителей международных рейсов. Доклады Казахской академии образования. № 1. 2017. C. 21-30.

17. Турчинова Г. В. Психолінгвістичні передумови оволодіння іноземною мовою для спеціальних цілей. Наукові записки : [збірник наукових статей] / М-во освіти і науки, молоді та спорту України, Нац. пед. ун-т імені М. П. Драгоманова ; укл. Л. Л. Макаренко. - Київ: Вид-во НПУ імені М. П. Драгоманова, 2011. Випуск LXXXXVIII (98). C. 201-207.

18. Pet'ko Lyudmila. About socio-culturological content in teaching subjects // Development strategy of science and education: Collection of scientific articles. - Fidelite editions, Namur, Belgique, 2017. P. 316-319.

19. Slyusarenko N., Soter M. The Webquest as a Means of Improving the Efficiency of Students' Foreign Language Training of Ukrainian Technical Institutions of Higher Education (Beginning of the $21^{\text {st }}$ Century). Intellectual Archive. Toronto: Shiny Word.Corp. (Canada). 2020. Vol. 9 (April/June). No. 2. Pp. 94-104.

DOI: https://doi.org/10.32370/IA_2020_06_13 


\title{
The Main Factors in the Development of Modern Ukrainian Language Education in the Southern Regions of Ukraine
}

\author{
Sushko Volodimir \\ ORCID https://orcid.org/0000-0001-6344-7318 \\ Postgraduate at the Department of Pedagogy and Education \\ Management Municipal Higher Educational Institution «Kherson Academy of \\ Continuing Education» of Kherson Region (Ukraine, Kherson)
}

\begin{abstract}
The article considers the development of modern Ukrainian-language education in the Southern region of Ukraine. Presented such areas of Ukrainian society as socio-political, socio-economic, and socio-cultural, identified the main factors in the development of Ukrainian-language education in the current implementation of state national and language policy, in particular of education. Among such factors are the formation of a selfsufficient citizen-patriot of Ukraine, the improvement of the communicative competencies of the language personality; development of information and communication technologies, development, strengthening and improvement of material and technical base of educational process and educational branch; polyethnicity of the Ukrainian state, multicultural educational environment, development of Ukrainian language didactics, development of speech and communicative competencies of the individual, his language culture, training of qualified scientific and pedagogical workers. To conclude the development of Ukrainian-language education is directly influenced by all the above-mentioned factors that enable the achievement and implementation of one of the main objectives of the national language and educational policy of Ukraine, - improving the communicative competencies of language personality.

Key words: bilingualism, communicative competence, language personality, language policy, national policy, polyethnicity, education reform, educational policy, Ukrainian language education.
\end{abstract}

Актуальність дослідження. Реформування сучасної освіти в Україні сьогодні є відгуком на внутрішньополітичні виклики в державі та на динамічну трансформацію глобалізованого світу. Сьогодні в країні відбувається формування нової парадигми національної системи освіти, осучаснення їі концепції, структури і змісту. Освіта в Україні як соціальне явище, що має свою концепцію, структуру, зміст, напрями, безпосередньо пов'язане з іншими складовими державної політики, зокрема мовної.

У сучасному українському суспільстві залишається відкритим питання вироблення чіткої національної мовної політики. Однією 3 нагальних потреб сьогодення $є$ створення умов для збереження й розвитку української мови та мов національних меншин [19, с. 232].

Україна є багатонаціональною державою. Грунтуючись на ідеологічних засадах, відповідно до чинного суспільно-політичного ладу, уряд проводить мовну політику таким чином, щоб урахувати й регіональні фактори суспільних відносин. До таких 
факторів належать дво- або багатомовність, своєрідність національного складу і міжнаціональних відносин, що історично склалися, роль окремих мов та їх носіїв у громадському житті $[3$, с. $649 ; 13 ; 14 ; 20]$.

Проблеми розвитку освітньої галузі, iï реформування, а також питання україномовної освіти досліджували науковці: Л. Березівська, В. Борисенко, І. Жорова, О. Кучерук, Т. Окуневич, В. Олексенко, М. Пентилюк, В. Спірін, О. Телегуз та ін.

Право на освіту є одним з основних, гарантованих Конституцією України, соціально-культурних прав громадян нашої держави, закріплене законом України «Про освіту», і забезпечується можливістю навчання в школі рідною мовою [2,с. 267].

Південний регіон України є багатонаціональним за своїм складом населення. Державною мовою в нашій країні є українська, і вона не може існувати поза освітнім процесом, що регламентовано чинним законодавством.

Таким чином, питання розвитку сучасної україномовної освіти в Південному регіоні України на сьогодні є актуальним.

Метою статті $\epsilon$ визначення основних чинників розвитку сучасної україномовної освіти в Південному регіоні України.

Виклад основного матеріалу. Українська літературна мова як державна і як рідна в закладах освіти не тільки вивчається, але й нею викладають навчальні дисципліни відповідно до чинного законодавства й освітньої мети. Викладання українською мовою та її вивчення здійснюється у закладах освіти, поза їх межами, дистанційно, а також за допомогою використання різних методів, вербальних i невербальних засобів. У нашій статті поняття «україномовна освіта» визначається саме в такому аспекті. Україномовний освітній процес безпосередньо залежить від рівня матеріально-технічної бази закладу, учасників процесу та технічного забезпечення конкретного здобувача освіти.

Україномовна освіта є явищем соціальним. Кожне явище, і кожен процес зумовлюються певними чинниками.

Одним із чинників розвитку україномовної освіти є урядова мовна політика, головним завданням якої є розв'язання мовних проблем у суспільстві, сприяння ефективному функціонуванню мови в різних сферах іiі застосування [19, с. 231]. 
Освіта сьогодні є одним із засобів розвитку особистості загалом і суспільства в цілому. Майбутнє соціуму залежить також і від рівня освіти, від іiї здатності динамічно реагувати на виклики й перетворення глобалізованого світу, на іiі відтворюваність, здатність впливати на суспільне життя, «адаптуючись до нових потреб суспільства i водночас активно впливаючи на його стан, визначаючи власне і самі потреби» [18].

Спираючись на вищезазначену думку, ми можемо зауважити, що однією із потреб сучасного українського суспільства $є$ забезпечення якості освіти, зокрема україномовної, на рівні світовому, тобто іiі удосконалення як духовної національної цінності, так і сутнісного її наповнення [1, с. 4].

Духовність не є суто абстрактною категорією. Вона формується й розвивається під впливом конкретних і відповідних дій. Так, наприклад, В. Олексенко зазначає, що рідна мова є надзвичайно важливим чинником формування духовного світу людини. Мову як духовне багатство треба вивчати та розвивати. Володіння мовою формує розуміння й усвідомлення необхідності мислити й висловлювати свої думки, залучає до «духовної культури народу, засвоєння традицій розвитку мови, iї функціонування у суспільстві» [11, с. 189].

Як бачимо, одним із засобів формування та розвитку духовних національних цінностей, духовного світу людини є вивчення рідної мови, зокрема украӥнської. Це є щее одним із важливих чинників розвитку украӥномовної освіти.

Чинником розвитку україномовної освіти, іiі гуманітарної складової, що є індикатором культурно-освітнього рівня суспільства [4, с. 89], відповідно до мети національно-патріотичного виховання в сучасній системі освіти України, $\epsilon$ також становлення самодостатнього громадянина-патріота Украӥни, гуманіста $i$ демократа, готового до виконання громадянських $i$ конституиійних обов'язків, до успадкування духовних і культурних надбань українського народу, досягнення високої культури взаємин, що сприяє єднанню українського народу, зміцненню соціальноекономічних, духовних, культурних основ розвитку українського суспільства i держави [8].

О. Спірін зауважує, що сучасне суспільство - це суспільство нового типу, глобальне суспільство, суспільство знань, які набуваються насамперед завдяки доступу до інформації, постають основною умовою благополуччя людини і держави; 
нове глобальне суспільство «сприяє взаємному проникненню культур, однак відкриває кожній культурі нові можливості для самореалізації» [18].

Отже, науково-технічний прогрес, що зумовив розвиток інформаційнокомунікативних технологій є ще одним чинником розвитку сучасної україномовної освіти.

Інформація сьогодні як товар $€$ однією 3 умов економічного зростання української держави, що може поліпшити та зміцнити матеріально-технічну базу як освітнього процесу (комп’ютеризація, оснащення інтерактивними дошками, нетбуками, вільний доступ до інтернету), так і технічного оснащення здобувачів освіти (різного виду гаджети, мобільний інтернет), і сприятиме розвитку й удосконаленню якості та доступності освіти, зокрема україномовної.

Україна є державою, де проживають різні етнічні групи, зокрема в Південному регіоні України. Кожна етнічна група має своє історичне коріння, свої традиції, культуру, що зумовлює утворення полікультурного мовного середовища під час освітнього процесу [9, с. 250; 16; 17].

Тому, одним із важливих чинників удосконалення украӥномовної освіти в Південному регіоні Украӥни є поліетнічність українського суспільства, оскільки в закладах освіти України особам, які належать до національних меншин, державою гарантується право на здобуття дошкільної та початкової освіти, поряд із державною мовою, мовою відповідної національної меншини [5].

Мовою закладів освіти, науки, державних установ, громадських і політичних організацій, офіційно-ділового спілкування, художньої літератури, театру, преси, кіно і телебачення є літературна мова [6, с. 7]. Літературна мова - це унормована форма національної мови, яка використовується для спілкування в суспільстві. Поширення та розвиток літературної мови залежить від стану мовної політики в державі, освіти, культурних традицій народу [19, с. 200].

Лінгводидактика як наука досліджує загальні закономірності навчання мовам, специфіку змісту методів і засобів навчання певній мові залежно від дидактичної мети й завдань, характеру матеріалу, який вивчається, умов монолінгвізму (одномовності) чи білінгвізму (двомовності), етапу навчання та інтелектуально-мовного розвитку учнів [2, с. 195]. 
М. Пентилюк наголошує, що українська мова як рідна і державна в усіх типах середніх і вищих закладів освіти є загальнодидактичною та концептуальною засадою української лінгводидактики і є засобом формування й розвитку мовної особистості «людини, яка любить, знає і береже рідну мову, з повагою ставиться до неї як до мови нашої держави, володіє ії виражальними засобами, користується нею у своїй професійній діяльності й у повсякденному житті» [12, с. 124].

Як бачимо, серед інших чинників розвитку україномовної освіти є розвиток української лінгводидактики як науки, одним з головних завдань якої є розвиток мовної особистості.

Відповідно до ключових компетентностей Нової української школи, сучасні здобувачі освіти мають уміти спілкуватися державною, а в разі відмінності рідною мовами, усно і письмово висловлювати й тлумачити поняття, думки, почуття, факти та погляди, через слухання, говоріння, читання, письмо, застосування мультимедійних засобів; здатні реагувати мовними засобами на повний спектр соціальних і культурних явищ - у навчанні, на роботі, вдома, у вільний час, усвідомлювати роль ефективного спілкування.

Науковиці Г. Кацавець i Л. Паламар пов’язують культуру особистості 3 досконалим знанням української літературної мови, бездоганним опануванням іiі стильовими тонкощами та умінням щоденно слугуватися ними. Рівень мовної культури особистості, наголошують науковці, залежить від правильності та точності висловлювання думки [6, с. 5].

Ще одним чинником удосконалення сучасної україномовної освіти є розвиток мовної та мовленнєвої культури особистості.

Т. Окуневич, порушуючи питання вдосконалення україномовного спілкування, висловлює думку, що вчитель, формуючи в учнів уміння і навички україномовного спілкування на уроках української мови, повинен «передбачити досягнення ними такого рівня комунікативної компетенції, який був би достатнім для здійснення спілкування у певних комунікативних сферах» [10, с. 123]. Як зазначає дослідниця, саме соціально-культурні і соціолінгвістичні знання, уміння і навички зумовлюють загальний розвиток особистості учня, а також його комунікативної компетенції, 
забезпечуючи входження в соціум і сприяючи соціалізації в новому суспільстві [10, c. 123].

Як бачимо, не менш важливим чинником розвитку україномовної освіти $\epsilon$ забезпечення освітнього прочесу науково-педагогічними працівниками відповідної кваліфікації, що можуть і повинні формувати у здобувачів освіти вміння й навички україномовного спілкування.

Задля вирішення вище зазначеного питання у системі післядипломної освіти Південного регіону України під час підвищення кваліфікації педпрацівників, зокрема у Комунальному вищому навчальному закладі «Херсонська академія неперервної освіти» Херсонської обласної ради, використовуються різні сучасні технології. Ними забезпечується «свідоме залучення педагога до розв'язання актуальної освітньої й соціокультурної проблематики; оволодіння ним сучасними знаннями та іншими інтелектуальними засобами; адекватний сучасній освітній ситуації професійний розвиток педагога; створення якісного продукту професійної діяльності (якість освіти учнів); розвиток внутрішнього потенціалу педагога» [4, с. 100].

О. Прокопова характеризує механізм творення комунікативної компетенції в наступній послідовності: мовна компетенція (знання засобів мови, одиниць і категорій усіх рівнів, а також правил, за якими будують мовні конструкції, й вміння такі правила застосовувати); мовленнєва компетенція (спроможність сприймати й розуміти висловлювання); комунікативна компетенція (здатність ефективно спілкуватися в різних умовах у ролі адресанта й адресата) [15, с. 55].

Комунікативна компетенція, як зазначає дослідниця, включає в себе: уміння людини спілкуватися з іншими людьми, доцільно використовуючи відповідні засоби рідної (української) мови в практиці, засоби виразності та ініціативні прояви. Вона також пропонує обов'язково використовувати на кожному занятті вправи, «спрямовані на очищення мовлення молодих українців від сумнозвісного суржику - явища, яке знижує якість не тільки мовлення, але й думки, адже мовленнєвий та мисленнєвий процеси взаємопов'язані» [15, с. 56].

Питання «очищення мовлення молодих українців від сумнозвісного суржику» у Південному регіоні України, через білінгвізм та поліетнічність, залишається достатньо актуальним. 
Висновки. Мова є явищем суспільним. Вербальна й невербальна комунікація між членами суспільства різного вікового цензу, різної статі, різних світоглядів, культур відбувається як на побутовому, так і на офіційному рівнях. Досягнення поставленої мети спілкування, взаєморозуміння між адресантом i адресатом безпосередньо залежить від комунікативних компетентностей. Такі навички успішного спілкування набуваються особою 3 досвідом у сімейно-родинному вихованні, у комунікаційному оточенні як ситуативному, так і довготривалому (друзі, знайомі, однолітки, колеги та інші), а також під час освітнього процесу в навчальних закладах.

Отже, одними з основних чинників розвитку сучасної україномовної освіти в Південному регіоні України, на нашу думку, є наступні, які можна поділити на три групи за основними напрямами суспільних відносин:

1. Соціально-політичні: реалізація державної освітньої та національної політики, що закріплено нормативно-правовою документацією, зміцнення основ розвитку українського суспільства i держави, становлення самодостатнього громадянина-патріота України. Ці чинники, їх змістовне наповнення безпосередньо залежать від чинного суспільно-політичного ладу та ідеологічного спрямування державної політики.

2. Соціально-економічні: науково-технічний прогрес, розвиток інформаційнокомунікативних технологій, зміцнення та поліпшення матеріально-технічної бази освітнього процесу й освітньої галузі зокрема. Ця група чинників зумовлюється економічним зростанням як кожним членом суспільства окремо, так і держави загалом.

3. Соціокультурні: поліетнічність української держави, полікультурне освітнє середовище, розвиток української лігводидактики, розвиток літературної української мовної системи, розвиток мовленнєво-комунікативних компетентностей особистості, іiі мовної культури, підготовка кваліфікованих науково-педагогічних працівників. Ця група чинників зумовлюється такими факторами, як двомовністю й поліетнічністю Південного регіону України, а також освітньою метою.

Таким чином, на розвиток україномовної освіти безпосередньо впливають усі вище зазначені чинники, що уможливлюють реалізацію державної політики України, направленої на вирішення мовного й освітнього питання, зокрема у Південному регіоні. 


\section{References}

1. Borysenko V. Y., Teleguz O. I. Natsionalna osvita $i$ formuvannya ukrainskoi modernoi natsii u 1921-1934 rokakh: yevropeiski tendentsii ta radianski realii [National education and the formation of the Ukrainian modern nation in 1921-1934: European trends and Soviet realities] : textbook, Kyiv, 2012. 156 p.

2. Goncharenko S. V. Ukrainskiy pedagogichniy slovnik [Ukrainian pedagogical dictionary]. Kyiv, 1997. 375 p.

3. Hrytsiak D. I. Mova iak obiekt derzhavnoi polityky, statusna i korpusna movna polityka [Language as an object of state policy, status and corpus language policy]. Derzhava i pravo, 2012. Issue 56. Pp. 649-654.

4. Zhorova I. Ya. Rozvytok shkilnoi humanitarnoi osvity : istorychnyi aspect [Development of school humanities education: historical aspect.]. Naukovyi chasopys. Seriia 5 : Pedahohichni nauky : realii ta perspektyvy : zb. nauk. prats. Kyiv : Vyd-vo NPU imeni M. P. Drahomanova, 2018. Issue 64. Pp. 89-92.

5. Zhorova I. Ya. Suchasni tehnolohii rozvytku profesionalizmu pedahohiv u systemi pisliadyplomnoi osvity Ukrainy [Modern technologies of professionalism development of teachers in the system of postgraduate education of Ukraine]. Visnyk Cherkaskoho universytetu. Pedahohichni nauky. 2019. No 1. Pp. 96-103.

6. Pro osvitu : Zakon Ukrayini vid 05 veresnia 2017 No 2145-VIII. [On Education: Law of Ukraine of September 5, 2017 No 2145-VIII. URL: https://zakon.rada.gov.ua/laws/show/2145-19

7. Katsavets G. M., Palamar L. M. Mova dilovikh paperiv: pidruchnik [The language of business papers: textbook]. 4 ed., revised and supplemented. Kyiv, 2008. 320 p.

8. Pro Vnesennia zmin do nakazu Ministerstva ocviti i nauki Ukrayini vid 16.06.2015 No. 641 : Nakaz MON Ukrayini vid 29 lypnia 2019. No 1038. [On amendments to the order of the Ministry of Education and Science of Ukraine dated 16.06.2015 No 641: Order of the Ministry of Education and Science of Ukraine dated 29 July 2019 No 1038.] URL: https://mon.gov.ua/ua/npa/pro-vnesennya-zmin-do-nakazu-ministerstva-osviti-i-nauki-ukrayinivid-16062015-641 (access date: 06.04.2020).

9. Odaynyk S. F. Upravlinnia navchalnim zakladom $v$ umovakh polikulturnogo osvitniogo seredovichshia [Management of an educational institution in a multicultural educational environment]. Pedagogical almanakh. 2015. Issue 25. Pp. 249-254.

10. Okunevych T. G. Formuvannia komunikativnoi kompetenzii uchniv zasobami ridnoi movy [Formation of communicative competence of students by means of native language]. Ped. science. 2016. May. No. 2 (53). Pp. 123-127.

11. Oleksenko V. P. Formuvannia dukhovnosti osobystosti zasobamy ridnoi movy [Formation of spirituality of the person by the means of native language]. Pedahohichni nauky. 2004. Issue XXXVI. Pp. 189-192.

12. Pentyliuk M. I. Rozvitok ukrainskoi lingvodidaktiki v konteksti Derzhstandartu bazovoi i povnoi serednioi osviti v Ukraini [Development of Ukrainian language didactics in 
the context of the State Standard of basic and complete secondary education in Ukraine]. Bulletin of Lviv University. Philological Series. 2010. No 50. Pp. 123-130.

13. Petko L. V. Vyklyky XXI stolittia dlia osvitnoho prostoru Ukrainy. Naukovi pratsi ChNU: nauk. zhurnal [The challenges of educational space in the $21-^{\text {st }}$ century]. Mykolaiv : Vydvo ChNU imeni Petra Mohyly, 2017. Issue 303. Vol. 291. Pp. 10-14.

14. Pet'ko L. V. Nacional'nyj komponent u formuvanni profesijno orijentovanogo inshomovnogo navchal'nogo seredovyshha $v$ umovah universytetu [National component in the way of forming professionally oriented educational environment in the conditions of university]. Naukovi zapysky Kyiv: Vyd-vo NPU imeni M. P. Dragomanova, 2014. Vol. CXVII (117). Pp. 125-135.

15. Prokopova O. P. Movlennievo-komunikatyvna kompetentnist iak odna iz skladovych profesiinoho stanovlennia fakhivtsia [Speech-communicative competence as one of the components of professional development of a specialist] : Zbirnyk naukovykh prats Kamianets-Podilskoho natsionalnoho universytetu imeni Ivana Ohiienka. Ser. Pedahohichna. 2010 No. 16. Pp. 54-57.

16. Sliusarenko N. V. Rol natsionalnoi kultury u formuvanni polikulturnoi osobystosti [The role of national culture in the formation of a multicultural personality] // II Dunaiski naukovi chytannia: dukhovno-tvorcha konstanta osobystosti : materialy mizhnar. nauk.-prakt. konf., prysv. 60-richchiu pedahohichnoho fak-tu Izmailskoho derzh. humanitarnoho un-tu (23 veresnia 2016 roku, m. Izmail) : v 2 t. Izmail : RVV IDHU ; «SMYL», 2016. Issue 2. Pp. $72-74$.

17. Sliusarenko N. V. Teoretychni osnovy polikulturnoho vykhovannia shkoliariv [Theoretical foundations of multicultural education of schoolchildren]. Tavriiskyi visnyk osvity. 2011. No 2. Pp. 30-35.

18. Слюсаренко Н. В. Теоретичні основи полікультурного виховання школярів. Таврійський вісник освіти. 2011. № 2. С. 30-35.

19. Spirin O. M. Metodologichni zasadi rozvitku suchasnikh sistem vishchoi osviti [Methodological principles of development of modern systems of higher education]. Bulletin of Zhytomyr State University named after Ivan Franko. 2005. Pp. 104-109. URL: http://eprints.zu.edu.ua/407/2/3C40E1CE.pdf (access date: 06.04.2020).

20. Ukrainska mova. Entsiklopediia [Ukrainian language. Encyclopedia]: za redakzieiu Muromtseva I. V. Kyiv, 2011. 400 p.

21. Pet'ko L. Priorities for the development of the Ukrainian national idea and the upbringing students of this modern era. Intellectual Archive. Toronto : Shiny Word.Corp. (Canada), 2017. Vol. 6. No. 5, September/October. Pp. 59-78.

Translation of the Title, Abstract and References to the Author's Language

УДК 373.5.016:811.161.2(477.7)»1920/1938»(043.3)

Сушко Володимир. Основні чинники розвитку сучасної україномовної освіти в Південному регіоні України. 
У статті розглянуто питання розвитку сучасної україномовної освіти в Південному регіоні України й визначено основні його чинники. Серед яких $\epsilon$ зміцнення основ розвитку українського суспільства i держави, становлення самодостатнього громадянина-патріота України, удосконалення комунікативних компетентностей; розвиток інформаційно-комунікативних технологій, економічні перетворення в Україні, розвиток, зміцнення та поліпшення матеріально-технічної бази освітньої галузі; поліетнічність української держави, полікультурне освітнє середовище, розвиток української лігводидактики, розвиток мовленнєвокомунікативних компетентностей особистості, iї мовної культури, підготовка кваліфікованих науково-педагогічних працівників. Автором зроблено висновок, що на розвиток україномовної освіти безпосередньо впливають усі вище зазначені чинники, що уможливлюють досягнення й реалізацію одного з основних завдань національної мовної й освітньої політики України, такого як удосконалення комунікативних компетентностей мовної особистості.

Ключові слова: білінгвізм, комунікативна компетентність, мовна особистість, мовна політика, національна політика, поліетнічність, реформування освіти, освітня політика, україномо8вна освіта.

\section{Jimepamypa}

1. Борисенко В. Й, Телегуз О. І. Національна освіта і формування української модерної нації у 1921-1934 роках: європейські тенденції та радянські реалії : навч. посібник. Київ, 2012. 156 с.

2. Гончаренко С. У. Український педагогічний словник. Київ, 1997. 375 с.

3. Грицяк Д. І. Мова як об’єкт державної політики, статусна і корпусна мовна політика. Держсава і право, 2012. Вип. 56. С. 649-654.

4. Жорова І. Я. Розвиток шкільної гуманітарної освіти : історичний аспект. Науковий часопис Національного педагогічного університету імені М. П. Драгоманова. Серія 5 : Педагогічні науки : реалії та перспективи : зб. наук. праць. Київ : Вид-во НПУ імені М. П. Драгоманова, 2018. Вип. 64. С. 89-92.

5. Жорова І. Я. Сучасні технології розвитку професіоналізму педагогів у системі післядипломної освіти України. Вісник Черкаського університету. Педагогічні науки. 2019. Вип. № 1. С. 96-103.

6. Про освіту : Закон України від 05 вер. 2017 p. № 2145-VIII. URL : https://zakon.rada.gov.ua/laws/show/2145-19 (дата звернення: 12.04.2020).

7. Кацавець Г. М., Паламар JI. М. Мова ділових паперів : підручник. 4-те вид., перероб. і доп. Київ, 2008. 320 с.

8. Про внесення змін до наказу Міністерства освіти і науки України від 16.06.2015 № 641 : Наказ $\mathrm{MOH}$ України від 29 липн., 2019 p. № 1038. URL: https://mon.gov.ua/ua/npa/pro-vnesennya-zmin-do-nakazu-ministerstva-osviti-i-naukiukrayini-vid-16062015-641 (дата звернення: 06.04.2020).

9. Одайник С. Ф. Управління навчальним закладом в умовах полікультурного освітнього середовища. Педагогічний альманах. 2015. Вип. 25. С. 249-254. 
10. Окуневич Т. Г. Формування комунікативної компетенції учнів засобами рідної мови. Науковий вісник МНУ ім. В. О. Сухомлинського. Пед. науки. 2016. Травень. № 2 (53). С. $123-127$.

11. Олексенко В. П. Формування духовності особистості засобами рідної мови. Педагогічні науки. 2004. Вип. XXXVI. С. 189-192.

12. Пентилюк M. I. Розвиток української лінгводидактики в контексті Держстандарту базової і повної середньої освіти в Україні. Вісник Львівського університету. Сер. Філологічна. 2010. № 50. С. 123-130.

13. Петько Л. В. Виклики XXI століття для освітнього простору України. Наукові пращі [Чорноморського державного університету імені Петра Могили комплексу "Києво-Могилянська академія"]. Серія : Педагогіка : наук. журн. / Чорном. держ. ун-т імені Петра Могили; ред. кол. : О. П. Мещанінов (голова) [та ін.]. Миколаїв : Вид-во ЧНУ імені Петра Могили, 2017. Т. 303. Вип. 291. С. 10-14.

14. Петько Л. В. Національний компонент у формуванні професійно орієнтованого іншомовного навчального середовища в умовах університету. Наукові записки : [збірник наукових статей] / М-во освіти і науки України, Нац. пед. ун-т імені М.П.Драгоманова ; укл. Л. Л. Макаренко. Київ : Вид-во НПУ імені М. П. Драгоманова, 2014. Випуск CXVII (117). С. 125-135. URI :

http://enpuir.npu.edu.ua/handle/123456789/7830

15. Прокопова О. П. Мовленнєво-комунікативна компетентність як одна із складових професійного становлення фахівця. Збірник наукових працьь Кам'янецьПодільського національного університету імені Івана Огієнка. Сер. Педагогічна. 2010. № 16. C. 54-57.

16. Слюсаренко Н. В. Роль національної культури у формуванні полікультурної особистості // II Дунайські наукові читання: духовно-творча константа особистості : матеріали міжнар. наук.-практ. конф., присв. 60-річчю педагогічного фак-ту Ізмаїльського держ. гуманітарного ун-ту (23 вересня 2016 року, м. Ізмаїл) : в 2 т. Ізмаїл : РВВ ІДГУ ; «СМИЛ», 2016. Т. 2. С. 72-74.

17. Слюсаренко Н. В. Теоретичні основи полікультурного виховання школярів. Таврійський вісник освіти. 2011. № 2. С. 30-35.

18. Спірін О. М. Методологічні засади розвитку сучасних систем вищої освіти. Вісник Житомирського державного університету ім. Івана Франка. 2005. C. 104-109. URL: http://eprints.zu.edu.ua/407/2/3C40E1CE.pdf (дата звернення: 06.04.2020).

19. Українська мова. Енциклопедія : за ред. І. В. Муромцева. Київ, 2011. 400 с.

20. Pet'ko L. Priorities for the development of the Ukrainian national idea and the upbringing students of this modern era. Intellectual Archive. Toronto : Shiny Word.Corp. (Canada), 2017. Vol. 6. No. 5, September/October. Pp. 59-78. 


\title{
From the Diary
}

\section{Hikmat Niyazi oqlu Vazirov \\ vezirov55@mail.ru}

\begin{abstract}
A completely new approach to a very interesting and popular issue of ancient and even modern times - problem of Judah's betrayal is considered in this article written in novel genre. It is shown that actually betrayal didn't happen. On the contrary, Judah consciously sacrificed his own and Jesus's life to save the humanity. Thus, Judah is not a betrayer, but a martyr-hero. As imam Hussein consciously sacrificed his and his family's lives to save and preserve the Islam. Thereby, Judah and Imam Hussein are the great martyr-heroes in the history.
\end{abstract}

\section{Аннотаичя}

Предложенная читателю крохотка (новелла-миниатюра) - это “перевод” “дневника” апостола Иуды с арамейского и древнегреческого языков. Из оборванных мыслей и записей Иуды становится понятным, что он вовсе не предавал Христа (Учителя), а лишь претворил в жизнь придуманный им самим же план помощи Христу и спасения человечества, которое, как думал Иуда, без Учения Христа сгинуло бы, а Учение без предательства забылось бы. До слов “две тысячи лет ненависти” Иуда писал дневник в своей земной жизни, начиная же с этих слов Иуда продолжает свой дневник в раю. Иуда объясняет, что Бог (Он) только теперь разрешил ему рассказать людям, как все было на самом деле. Для этого Иуда передал свой дневник автору настоящей новеллы-крохотки. Иуда в дневнике намекает, что его роль в аресте Учителя ничтожна - Христа же в лицо знали все: и государство, и ненавидившие Его попы, и зеленщики, и солдаты... и слушали каждый день.

Дневник Иуды - это также первоисточник правды об имаме Хусейне, внуке пророка Мухаммеда (Деда). Оказывается, имам Хусейн принес и себя, и все свое семейство (72 души) в жертву тоже осознанно, и тоже ради спасения человечества, которое, как он думал, без Учения его Деда пропало бы. Впервые в истории показано, что именно Иуда предлагает людям не обижать рыб и другую бессловесную живность. Из дневника явствует, что Иуда возмущен злодейством фашистов и дашнакских палачей, натворивших Ходжалы и Саласпилс. И он уже сомневается, станут ли они когда-нибудь человеками.

Настоящая крохотка (новелла-миниатюра) охраняется Законом АР Об авторском праве и смежных правах (свидетельство №10194 от 05.06.2018).

... предателей не любят... предательство помнят. Помнят долго. Главное, что люди никогда не забудут моё... “предательство”. Всегда будут помнить. И ничего со мной не случится, если даже сотню лет будут проклинать меня. За то, что я предал Учителя. Создателя Учения. Ведь Он же никогда не внушит мне предать Учителя. И Учитель никогда бы не предал меня... внушив мне предать Его Самого. Нет. Это не можно. Иначе это не было бы Учением, а был бы Его грех. А намек на то, что один из вас предаст меня - так на то и Учитель: все знает! Это не внушение... Надежда, предвосхищение... предвкушение... 
Только я́ додумался “предать” Его. Потому я - и ученик любимый. Учитель знает, кого любить больше. Ни разу меня бараном не назвал. Одна кровь... И тетя Мария... все знала... и даже не пыталась отговорить меня... По-другому же Учения не спасти... И людей тоже... Ведь люди не будут помнить Учения без чего-то великого. Я их хорошо знаю: ведь сколько Их было до Учителя... А Учение еще такое хрупкое, беззащитное... Придется предать Учителя подло, из “корысти”... Уф!.. с наветом... Такое вы́зовет всеобщую ненависть. Хорошо бы за тридцать монет... Нет, не золотых, пожалуй. Лучше, серебряных. Но, думаю, этого все же недостаточно. Надо, чтобы люди ду́мали ка́к я мучился. Значит, решено!.. Повеситься!.. Но... только после того, как все узна́ют, что Учитель “воскрес... живой (ведь такое уже было)... И так, чтобы напоминало Учение... Значит, на смоковнице, фиге... винная ягода, инжир. Нет. Мало. Люди могут забыть. Надо бы обнять и поцеловать Учителя. Вот тогда будут помнить долго. Долго будут помнить, ка́к Учитель страдал... ка́к я обрек Его на это. Будут помнить мое “предательство” и страдания Учителя - никогда не забудут Учения... Да, еще... Не забыть бы вернуть деньги... Только сыграть искусно, чтоб не догадались... И ученики... И чтобы написали, что я - предатель...

Один Он знал, зачем я все это сделал... А люди... - только через пару сотен лет... Ведь им и в голову не придет хотя бы задуматься о том, что Учителя же все знали в лицо: и государство, и попы, и зеленщики, и солдаты, и уличные... Учитель же и Сам без никого мог бы придти и отдать Себя им в руки... но... нужно же свидетельство... против Него...

... две тысячи лет ненависти. Две тысячи лет они думали, что я на самом дне. Вот глупые. А меня же там не было никогда. Даже мудрый Хайям думал, что я - предатель: “... среди апостолов и то... один - предатель” ... А я ведь спас их. Не будь же Учения - не было бы и их... а не будь моего “предательства", не сохранилось бы Учение ... И Данте заблуждался, думая, что я в аду... И зря судил... Мы с Дедом и Али ему только померещились... И Варнава врет... Не может же Он обманывать... и сделать так, чтобы вместо Учителя распяли меня или другого невинного человека... Наверное, потому и говорил Учитель: “Не судите”... Только Он знал, что не настоящий предатель я. Я только подсобил Учителю... Ведь будь я настоящим предателем... Дед в своем Писании сказал бы об этом... И первым меня прокляла бы тетя Мария... Не прокляла же... Но... церковь или не понимает, или же не хочет говорить правду обо мне... ведь когда я их привел, я же сказал: радуйся, Равви... Матфей слышал... но... не то понял... как хорошо... не понял... Пришло время и людям узнать... правду. О́н разрешил. Теперь можно...

А как я все это провернул?!. Какая игра?!. Ай да молодец!.. Даже Матфей, и Марк, и Лука, и Иоанн... А что же ученики?.. Защитили Учителя?.. Отреклись?!. Убежали?!. Хороши... Даже Петр?.. его падение... А ведь ни один из них в своём Писании ничего не сказал о своем “подвиге”... Как же верить им до конца?.. Петра и других простили... и возвеличили... А предатель - я?!. До сих пор?!. Сохранителя... ?!. Только Мария-ученица... А тезки здесь нет...

Другие шахиды-мученики тоже здесь. Часто вижу Хусейна. Ибн Али. Все его семейство и челядь здесь. Вот он - действительно молодец. Герой. Какая великая душа. Какая отвага. Это тебе не я. Одному-то легче. А каково было ему. Знать, что́ сделают с твоим семейством, и 
отдать всех. 72 человека. Осознанно. Так же осознанно, как и я принес в жертву и Учителя, и себя. Ради Учения для людей... А его предали?.. А воду?.. А руку?.. Натворивших это злодейство я здесь не видел. В любом случае, он большая умница. Как все рассчитал... Почти полторы тысячи лет люди помнят и это... но уже настоящее, подлое злодейство и предательство. Помнят, ка́к страдал Хусейн. Мученик. Праведник. Отмечают каждый год. Целых сорок дней скорби. Сработало. Без его подвига могли бы забыть и следующее Учение. Учение его Деда. Хотя?.. Какое Оно следующее?.. Оно же то же самое, только подчищенное и подправленное - ведь что-что, а пачкать и портить совершенное люди так хорошо умеют. Вот Он и наказал исправить, подчистить, подправить... что Дед и сделал. Здесь Хусейну тоже хорошо. Живем рядом. Часто беседуем с Учителем. Учитель его уважает, а с его Дедом дружит... Одна же кровь... У Деда и Али обиды прошли - дело-то общее сделали. А обиды были?.. А Он любит нас всех.

Мы оба принесли жертву осознанно. Сами. Без никакого из людей. И Учитель здесь признался, что я поступил правильно... И мы с Ним не сговаривались!.. Правда!.. Здесь Хусейна и меня почитают двумя са́мыми великомучениками...

А люди там?.. Мыслят Учения?.. И никак эти глупые не поймут, что Он - один, и другого нет... И ничего нет... И все кончится... И начнется с начала... Вот неразумные... И зачем им все это?!. Не ведают, что творят!.. И чего им не живется?!. О́н же повелел!.. И дозволил!..

Случайно услышал, как Дед говорил Учителю, что так эти люди ничего и не поняли... надо бы спросить с них... Видать, пора... Самое время. Надо бы кому-то придти туда снова. И еще раз объяснить, чтоб не ждали прихода другого... И одумались... И пусть все ходят друг к другу... И в мечеть... И в церковь... И в синагогу... Особенно там... О́н велит... Он же один... Только имен много. Это же Его́ дома... А разногласия... так в каждом же доме... ... а рыбы?.. Этим людишкам не жалко рыб?!. А в чем они виноваты? Только в том, что О́н сделал их такими... бессловесными... Если они не умеют мычать, кукарекать, пищать, чирикать или говорить, значит... их можно мучить?.. За что?.. Они жалеют даже глупую курицу... Только за то, что она шумит. А рыбы не умеют. Поэтому их можно вытащить из воды, и ждать, когда сдохнут?.. Им все равно?.. Они же задыхаются... Мучаются... Долго... Часами... Перед смертью они подвергаются страшным пыткам... Какая жестокость!.. Неужели люди не понимают, что это ужасно?..

О́н так сделал, чтобы волки кушали зайцев, кошки ели мышей. Наверное, та́к нужно. Кушают, но не мучают же. Медведи ловят рыб и едят. Не мучают. Они сразу умирают... А люди?.. Разве О́н им сказал, что рыб нужно мучить?.. В Писаниях так не сказано. Даже рыбы это знают. А они - нет!.. Не читают же... А ведь Писание потому и названо "Чтение", “Читай”, “Книга”, “Учебник” или “Учение”, чтобы люди учились... Жить... Но они этого не понимают. Они даже не понимают, что Он назидательно испы́тывает их... Он же сделал рыб бессловесными, чтобы люди са́ми додумались... А они не понимают... Куда смотрят законодатели... и эти... зеленые?..

... а детей?.. а Ходжалы?.. а Саласпилс?.. Разве О́н научил их этому?!. Станут ли они человеками?.. Когда-нибудь?.. 
... и потому... судите, да побиты и блаженны будете... а может... не судимы будете...

\section{Translation of the Title and affiliation to the Author's Language}

\section{ИЗ ДНЕВНИКА}

(перевод с арамейского и древнегреческого)

\section{Хикмет Ниязи оглу Везиров,}

Руководитель лаборатории Института физики Национальной Академии наук

Азербайджана, г. Баку

vezirov55@mail.ru 
DOI: 10.32370/IA_2020_09_20

\title{
The Pliability of the Joints of Wooden Elements in the Work of Wooden Reinforced Stress Ribbon Structures
}

\author{
Kravz Andrii, \\ Senior Lecturer. National Academy Fine Arts and Architecture \\ orcid.org/0000-0002-9585-1654 (Kyiv, Ukraine) \\ Demchyna Bohdan, \\ Doctor of Engineering, Professor. National University «Lviv Polytechnic» \\ ORCID:0000-0002-3498-1519 (Lviv, Ukraine)
}

\begin{abstract}
The behavior of a wooden stress ribbon structures reinforced with steel rope under the action of a load evenly distributed along the entire length of the cable was investigated. The analysis of the results of static tests of the wooden reinforced cable is given.

To ensure the stability and geometric invariance of the structures formed by rigid threads, an important role is played by taking into account the pliability of the nodal joints of the wooden elements of the cable. Based on this, the deformability of the joints of the wooden elements of the cable on the three type of joints and its effect on the deflection of the cable were investigated. The coefficient of deformability of joints was suggested, which took into account the nonlinear dependence of the deformation of joints of wooden elements of the cable on the applied load.

Deflections of wooden stress ribbon structures reinforced with steel rope are calculated taking into account the pliability of joints of individual wooden elements. The results of calculations are compared with experimental data.

Keywords: Suspension roof, wooden structures, rigid threads, stress ribbon, pliability of supports, static calculation, load, punched metal plate fasteners, joints of wooden elements.

Актуальність дослідження. Ключовою проблемою застосування висячих покриттів є задача підвищення їх жорсткості. До числа перспективних напрямків по вирішенню даної проблеми відносять розробку покриттів з використанням розтягнутих згинальножорстких ниток. На сьогоднішній день найбільш широкого застосування знайшли жорсткі ванти виконані у вигляді зігнутих ферм та зварних або прокатних двотаврів із маловуглецевої або низьколегованої сталі. Проте використання маловуглецевої або низьколегованої сталі для вантових конструкцій в замін високоміцних канатів знижує несучу здатність покриття, окрім того зростає власна вага покриття, що призводить до збільшення витрат матеріалів на усі опорні конструкції.

Для рішення цієї проблеми пропонується спільне застосування дерев'яних елементів та канатів, коли частину розтягуючих зусиль будуть нести сталеві канати, що мають великий розрахунковий опір на розтяг, а стабілізацію вант будуть забезпечувати дерев’яні елементи, з достатньо великою жорсткістю.
\end{abstract}


Аналіз останніх досліджень і публікацій. Попереднім аналізом літературних джерел, встановлено, що тема дерев'яних вант досліджувалась мало, хоча такий варіант збільшення жорсткості висячих конструкцій є досить ефективним, оскільки не значно збільшує власну вагу покриття через незначну об'ємну вагу деревини. Kristoffer Persson [1], Samuel Hofverberg [2], David Gustafsson, Martin Ingvarsson [3] та інші, дослідивши існуючі дерев'яні вантові конструкції, зробили висновок про необхідність подальших досліджень з'єднань дерев'яних елементів по довжині ванти. Методика досліджень дерев'яних армованих вант подана в роботах $[4,5]$. Результати експериментальних досліджень публікувались в роботах $[6,7,8,9]$.

Мета і задачі дослідження. Метою даного дослідження був розрахунок податливості з'єднань окремих дерев'яних елементів та аналіз його впливу на деформативність дерев'яних вант.

Виклад основного матеріалу. Відмінною ознакою між дослідними зразками вант різних серій була конструкція з'єднань дерев'яних елементів [4,5]. Дослідженню цього питання була приділена особлива увага. Це пов’язано з тим, що, відповідно до розрахунків [10], з'єднання елементів ванти повинно було стабілізувати канат, що потребувало сприйняття стискаючих та розтягуючих зусиль, а також моменту, який виникав від прикладання зовнішніх зусиль. У вузлах необхідно було забезпечити жорсткість з'єднання близьку до жорсткості дерев'яного тіла ванти.

Методика проведення випробувань. Дерев'яні елементи зразка серії ВД-1 з’єднувались між собою за допомогою металевих пластин товщиною 2мм, які прикріплювались до дошки саморізами $35 \times 3$ (рис. 1).

a)

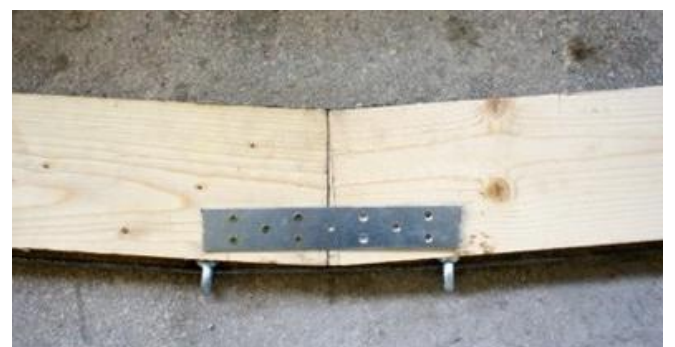

Рис. 1. 3'єднання дерев'яних елементів металевими пластинами;

а) загальний вигляд; б) конструктивна схема 
3'єднання дерев'яних елементів ванти зразка серії ВД-2 були виконані за допомогою похиловклеєних стержнів по системі ЦНИИСК (рис. 2). Розрахунки елементів з'єднання були проведені відповідно до п.7.38-7.49 [11].

a)

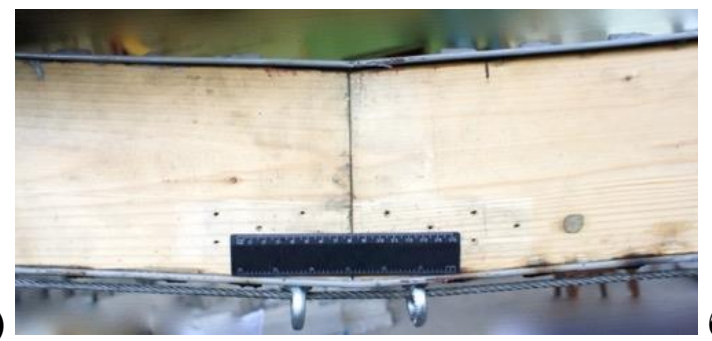

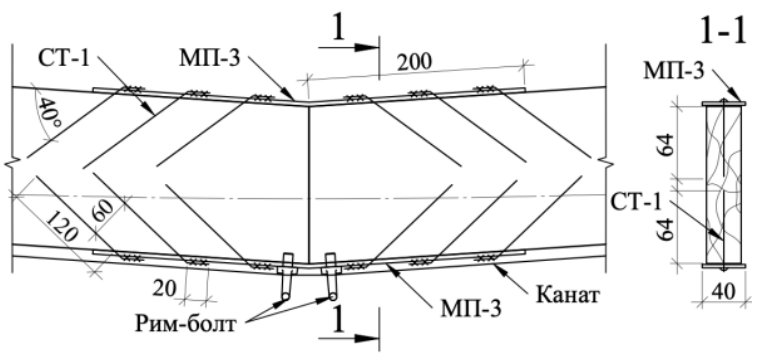

Рис. 2. 3'єднання дерев'яних елементів за допомогою похиловклеєних стержнів, та кріплення канату; а) загальний вигляд; б) конструктивна схема

Відповідно до програми експериментальних досліджень було розроблено третій тип з'єднання дерев'яних елементів для зразка ванти серії ВД-3 за допомогою металевих зубчатих пластин (МЗП) (рис. 3).

a)
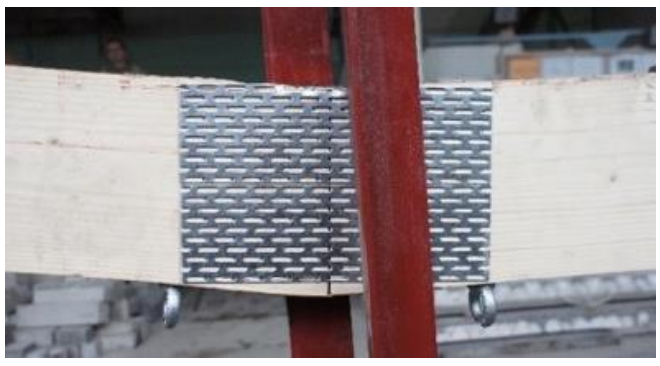

б)

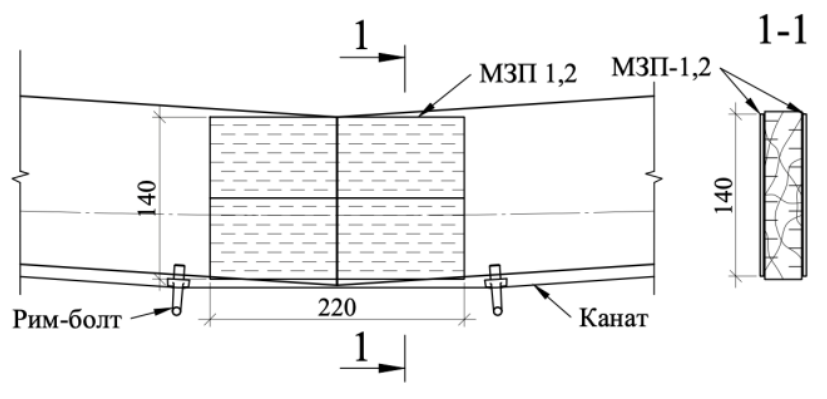

$1-1$

Рис. 3. 3'єднання дерев'яних дощатих елементів металозубчатими пластинами;

а) загальний вигляд; б) конструктивна схема

Досліджувана дерев'яна ванта складалась 3 п’яти дерев'яних елементів (рис. 4).

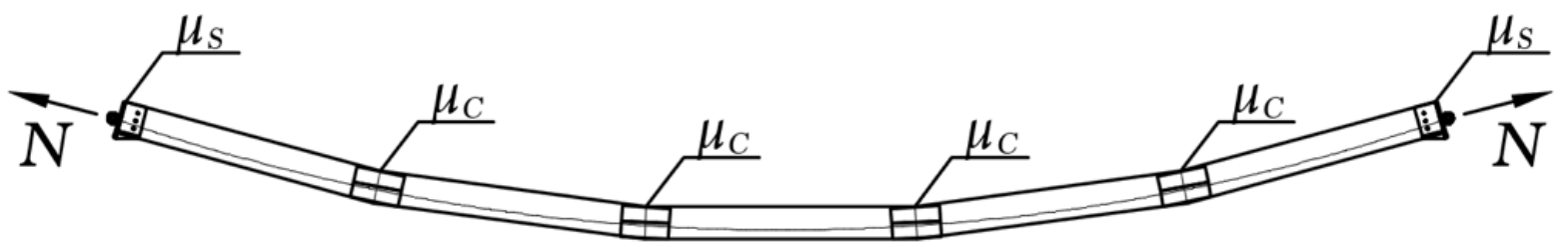

Рис. 4. Схема податливості з'єднань дерев'яних елементів ванти.

Результати досліджень. На рівні з податливістю опор [8], на роботу жорстких ниток впливає податливість з’єднань елементів конструкції.

Податливість з'єднань елементів ванти від приросту зусилля $\Delta N=1 \kappa \mathrm{H}$, обчислювалась за формулою: 


$$
\mu=2 \mu_{S}+4 \mu_{C}
$$

де $\mu_{S}=10^{-6} \mathrm{M} /$ кH - експериментальне значення податливості опорного вузла дерев'яної ванти від $\Delta N=1 \kappa \mathrm{H}$;

$\mu_{\mathrm{C}}-$ податливість одного з'єднання дерев'яних елементів ванти від $\Delta N=1 \kappa \mathrm{H}$, визначена за результатами експериментальних досліджень на розтяг з'єднань дерев'яних елементів на металозубчастих пластинах (МЗП) (рис. 5):

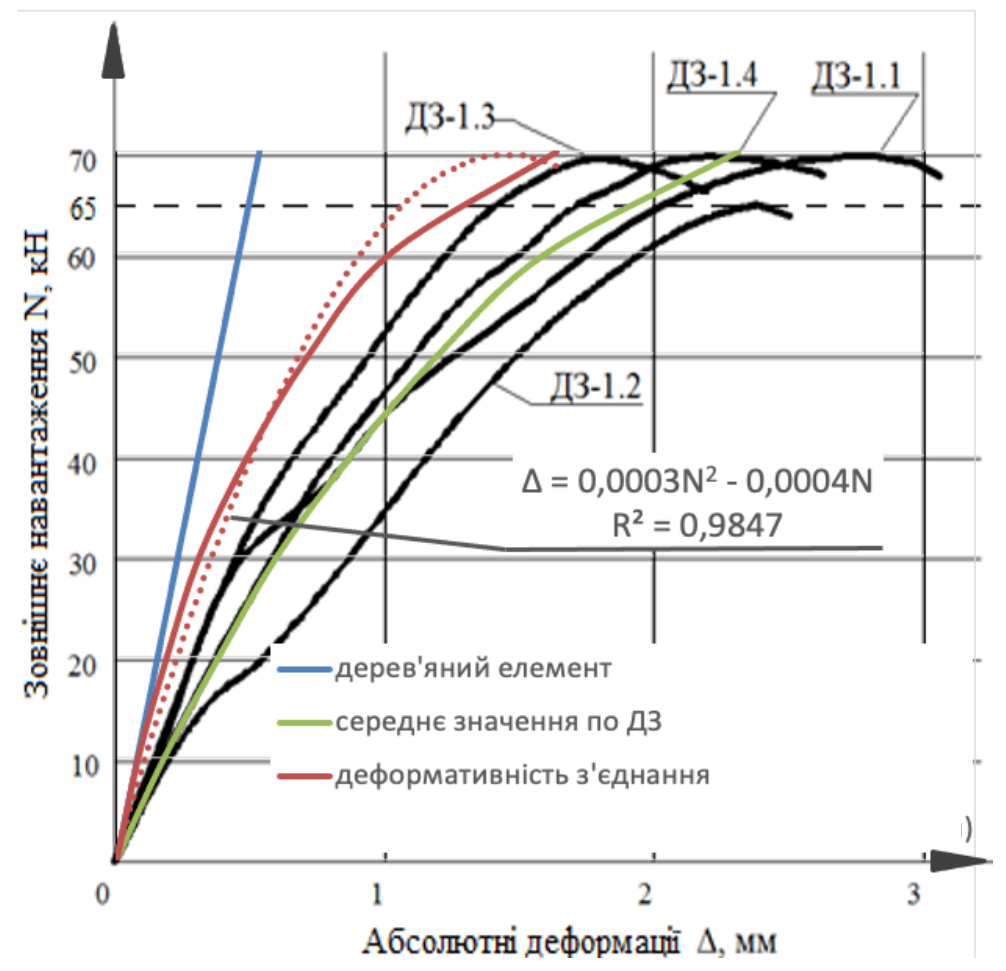

Рис. 5. Деформація з'єднання на МЗП.

Абсолютні деформації з'єднання на металозубчатих пластинах $(\Delta)$ визначались за квадратичною залежністю від розтягуючого зусилля $N$, з графіка деформації дослідних зразків ДЗ-1.1 - ДЗ-1.4. (див. рис. 5) [7].

$$
\Delta=0,0003 N^{2}-0,0004 N, \mathrm{MM}
$$

Відповідно, податливість з'єднання дерев'яних елементів ванти на МЗП від $\Delta N=$ 1кН визначалась:

$$
\mu_{\mathrm{C}}=\frac{\Delta}{N}=3 \cdot 10^{-7} \cdot N-4 \cdot 10^{-7} \mathrm{M} / \mathrm{\kappa H}
$$

Податливість з'єднань дерев'яних елементів вант інших серій визначались за аналогією до з'єднань на МЗП, враховуючи їхню пружно-пластичну роботу. Результати обчислень наведені в табл. 1 . 
Таблиця 1.

Деформативність з’єднань дерев’яних елементів ванти

\begin{tabular}{|c|c|c|}
\hline Серія & Абсолютна деформація з'єднання $\Delta_{C}$, мм & Податливість зсднання $\boldsymbol{\mu}_{\mathrm{C}}, \mathbf{м м} / \mathbf{к H}$ \\
\hline ВД-1 & $0,003 N^{2}-0,07 N$ & $0,003 N-0,07$ \\
\hline ВД-2 & $0,001 N^{2}-0,01 N$ & $0,001 N-0,01$ \\
\hline ВД-3 & $0,0003 N^{2}-0,0004 N$ & $0,0003 N-0,0004$ \\
\hline
\end{tabular}

Отримані результати податливості з'єднань були використані для обчислення розрахункових значень прогинів дерев'яної армованої ванти в середині прольоту $\left(w^{\text {theor }}\right)$ від додаткового навантаження $(p=6 \kappa \mathrm{H} / \mathrm{M})$ :

$$
w^{\text {theor }}=\Delta \mathrm{L}_{\text {пр }} \frac{3}{16} \frac{l}{f_{0}}
$$

де $\Delta L_{\text {пр }}$ - приведене видовження ванти, яке складається з видовження тіла ванти, зближення опор і деформативності з'єднань дерев'яних елементів ванти:

$$
\Delta L_{\text {пр }}=\Delta L+v H+\mu N
$$

Видовження ванти від навантаження:

$$
\Delta L=\frac{N L}{E A}
$$

$L=l+\frac{8}{3} \cdot \frac{f_{0}^{2}}{l}=6+\frac{8}{3} \cdot \frac{0,5^{2}}{6}=6,1111 \mathrm{M}-$ початкова довжина ванти;

$l=6 \mathrm{M}-$ проліт ванти;

$f_{0}=0,5 \mathrm{M}$ - початкова стріла провису в середині прольоту від постійного навантаження $g$, що не викликало появи згинального моменту ванти;

Поздовжнє зусилля, що виникає у ванті від додаткового навантаження $(p, \kappa \mathrm{H} / \mathrm{M})$ :

$$
N=\sqrt{H^{2}+V^{2}}
$$

де $V=\frac{p l}{2}=\frac{6 \cdot 6}{2}=18$, кН - вертикальна опорна реакція;

$H$ - розпір ванти;

$v=v_{A}+v_{B}=6,75 \cdot 10^{-5}, \mathrm{M} /$ кН - податливість опор - експериментальне значення зближення опор $A$ та $B$ від $\Delta H=1 \kappa \mathrm{H}$;

$\mu=2 \mu_{S}+4 \mu_{C}-$ податливість 3'єднань дерев'яних елементів ванти від $\Delta N=1 \kappa \mathrm{H}$, приймалась згідно табл. 1; 
Для аналізу деформативності конструкції в залежності від типу з'єднання дерев'яних елементів було проведено аналіз прогинів в середині прольоту вант трьох серій від рівномірно розподіленого навантаження $p$ (рис. 6).

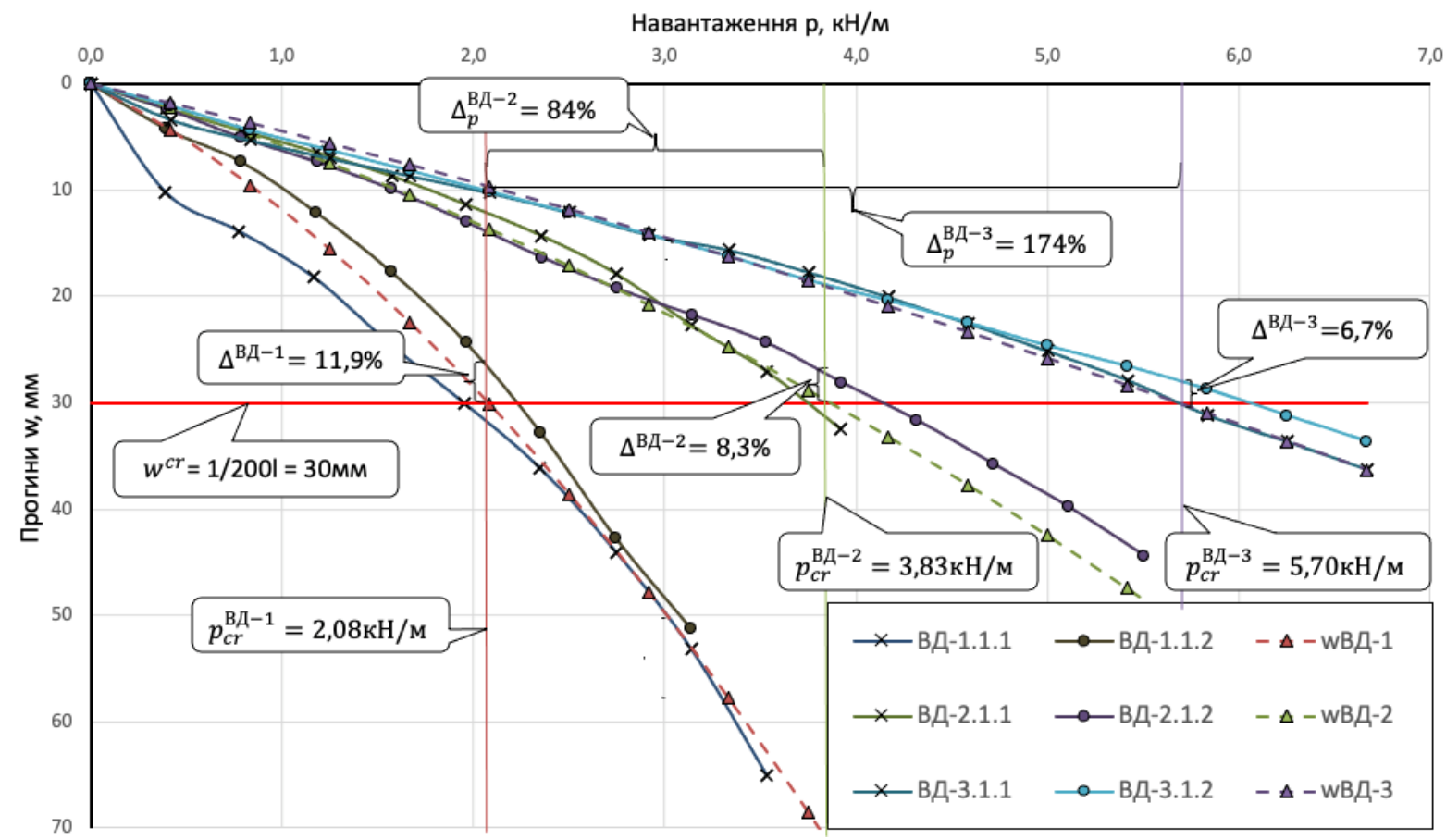

Рис. 6. Порівняння прогинів в середині прольоту вант трьох серій від рівномірно розподіленого навантаження $p$.

Як бачимо з графіків (рис. 6), прогини ванти при рівномірно розподіленому навантажені сильно залежать від податливості з'єднань. Так граничне навантаження при якому ванта досягала граничного прогину 30мм, для зразків серї ВД-2 та серії ВД-3 було на 84\% і 174\% відповідно, більше ніж для зразків серії ВД-1.

Експериментальні значення прогинів ванти 3 точністю до 11,9\% відповідають розрахунковим значенням, обчисленим з урахуванням податливості з'єднань дерев'яних елементів по відповідних серіях. Це підтверджує достовірність обчислених коефіцієнтів податливості з'єднань дерев'яних елементів та придатність методики розрахунку прогинів яка їх враховує.

\section{Висновки:}

1) 3 виконаного аналізу деформативності вант та дослідження окремих з'єднань, запропоновані коефіцієнти податливості з'єднань дерев'яних елементів, а саме:

- для з'єднання за допомогою металевих пластин $\mu=0,003 N-0,07$; 
- д для з'єднання на похиловклеєних стержнях $\mu=0,001 N-0,01$;

- для з'єднань на металозубчатих пластинах $\mu=0,0003 N-0,0004$.

2) Запропоновані коефіцієнти дали задовільну збіжність експериментальних i розрахункових прогинів серій: ВД-1 до 11,9\%, ВД-2 до 8,3\%, ВД-3 до 6,7\%.

\section{References}

1. Gustafsson, D. Ingvarsson M. "Application of Asymmetric Loads on Cable Shaped Structures" (2017). MA thesis. Chalmers University of Technology.

2. Hofverberg, S. (2016). Long-span tensile timber roof structures (Master's thesis, Chalmers University of Technology, Divison of Structural Engineering).

3. Persson, K.. (2018). "Analysis of Catenary Shaped Timber Structures.".

4. Kravz A.R. (2014). Metodyka eksperymental'nykh doslidzhen' derev'yanykh vant armovanykh stalevym kanatom zi z"yednannyam okremykh derev"yanykh elementiv metalorozdrukiv plastykamy [Methods of experimental research of wooden stress ribbon structures reinforced with steel rope with the connection of individual wooden elements with punched metal plate]. Perspektivnyye napravleniya innovatsionnogo razvitiya stroitel'stva $i$ podgotovki inzhenernykh kadrov: Sbornik nauchnykh statey XIX Mezhdunarodnogo nauchnometodicheskogo seminara; Brest 23-25.10.2014. - Brest: BrSTU,2014. - Part 1. 100-106. (in Ukrainian).

5. Kravz A.R., Demchyna B.G. (2013). Metodyka eksperymental'nykh doslidzhen' derev'yanykh vant armovanykh stal'nym kanatom zi z"yednannyam okremykh derev"yanykh elementiv vkleyenymy sterzhnyamy [Methods of experimental research of wooden stress ribbon structures reinforced with steel rope with the connection of individual wooden elements with glued rods]. Zbirnyk naukovykh prats' NUK 2, 38-42 (in Ukrainian).

6. Kravz A.R., Demchyna B.G. (2013). Eksperymental'ne doslidzhennya derev'yanykh vant armovanykh stal'nym kanatom zi z"yednannyam na vkleyenykh sterzhnyakh [Experimental research of wooden stress ribbon structures reinforced with steel rope with connection on glued rods]. Naukovo-tekhnichni problemy suchasnoho zalizobetonu. Vpusk 78. Knyha 2. K. DP NDIBK, 235-242 (in Ukrainian).

7. Demchyna B.G., Kravz A.R., Shidlovsky J., Yaremko I. (2014). Doslidzhennya na roztyah z"yednan' derev"yanykh elementiv na metalozubchastykh plastynakh (MZP) [Tensile tests of joints of wooden elements on punched metal plate]. Visnyk L'vivs'koho natsional'noho ahrarnoho universytetu. Seriya : Arkhitektura i sil's'kohospodars'ke budivnytstvo. - 15. 34-40 (in Ukrainian).

8. Kravz A.R., Demchyna B.G. (2020). Pidkhody do vrakhuvannya horyzontal'nykh peremishchen' fundamentiv v roboti derev"yanykh armovanykh vant. [Approaches to taking into account horizontal movements of foundations in the work of wooden reinforced cables]. Naukovo-tekhnichnyy zbirnyk «Osnovy ta fundamenty». Kyyiv: KNUBA, 2020. № 40. 51-64. (in Ukrainian).

9. Kravz A.R., Demchyna B.G. (2021) Vplyv velychyny poperedn'oho natyahu kanatu na napruzheno-deformovanyy stan derev'yanykh armovanykh vant. [Influence of the value of the 
pre-tension of the rope on the stress-strain state of wooden reinforced cables]. Theoretical and scientific bases of development of scientific thought: abstracts of reports of the International Scientific Conference on New Trends in Science and Education. ISBN 978-1-63684-356-8. DOI 10.46299/ISG.2021.I.V (Rome, Italy, 16 - 19.02.2021 p.). (in Ukrainian).

10. Svetnikov A. A. K voprosu ob ispol'zovanii prokatnykh profiley v kachestve materiala gibkikh nitey [On the question of using rolled profiles as a material for flexible threads] / A. A. Svetnikov. // Izv.vuzov. Stroitel'stvo. - 1996. - №8. - S. 3-6. (in Russian).

11. SNiP ÍÍ-25-80. Derevyannyye konstruktsii [Wooden structures] / Gosstroy SSSR. M.: Stroyizdat, 1982. - 66. (in Russian). 


\title{
Stress-Strain State of Wooden Columns Under Uneven Local Heating
}

\author{
Andrii Pelekh \\ Postgraduate. National University «Lviv Polytechnic» \\ http://orcid.org/0000-0002-0390-0915 (Lviv, Ukraine)
}

\begin{abstract}
The fire resistance of wooden structures is an important stage in the design of wooden structures. For many years, scientists around the world have been studying the behavior of a structure in a fire and trying to predict the consequences. In this work, the work of wooden compressed elements under the action of local heating is considered. The aim of the work is to find the effect of fire on a compressed element at any point of its crosssection using analytical methods. As the modern normative base recommends the use of approximate methods and empirical coefficients, it does not allow to estimate just approximately the work of a structural element during a fire and to take into account the non-uniform heating of the element's body. To solve the problem, we used the Heaviside mathematical functions and the system of discrete equations. As a result, dependences describing the change of strength and strain characteristics in any point of the element body during its local heating were obtained.
\end{abstract}

Keywords: wood, high temperature, wood columns, fire, fire design.

Постановка проблеми. У зв’язку із особливостями властивостей деревини, у випадку iii використання в якості несучої конструкції дуже важливо річ відіграє саме іiі вогнестійкість [1,2]. Також важливо є забезпечити деформативність дерев'яних конструктивних елементів у межах граничних значень. У даному випадку проблемою $є$ виявлення залежностей міцнісних і деформіних характеристик деревини, а саме урахування їх зменшення, при дії температури від іiі розміщення на тілі несучої конструкції та зміни .3 часом $[3,4]$.

Аналіз останніх досліджень та публікацій. Проблема зміни міцнісних та деформіних характеристик дерева під час дії високих температур, не є новою[5,6]. Також важливою є проблема втрати стійкості при зміні характеристик для стиснутих елементів [7-9]. Проте автори не змогли уникнути використання емпіричних коефіцієнтів, що пропонується у нормативній документації $[3,4]$.

Сучасні норми при уточнювальному розрахунку вимагають урахування цих залежностей [4]. Проте вплив даних факторів враховують із введенням емпіричних коефіцієнтів, що у свою чергу не дозволяють із достатньою точністю врахувати розподіл характеристик по тілу колони. Автором було виконано аналіз повзучих характеристик 
під час дії високих температуру [10], у цій же роботі подано пошуки аналітичними методами зміни характеристик під час одностороннього локального нагріву.

Постановка завдання. Отримати аналітичними методами розв'язки задач про розподіл міцнісних та деформівних характеристик, тим самим уникнути введення емпіричних коефіцієнтів в розрахунок.

\section{Виклад основного матеріалу.}

Для розв'язання даної задачі спочатку була виконана апроксимація міцнісних та деформівних характеристик. Для апроксимації були використанні дані із [4], що відображені на рис. 1 та рис.2.:

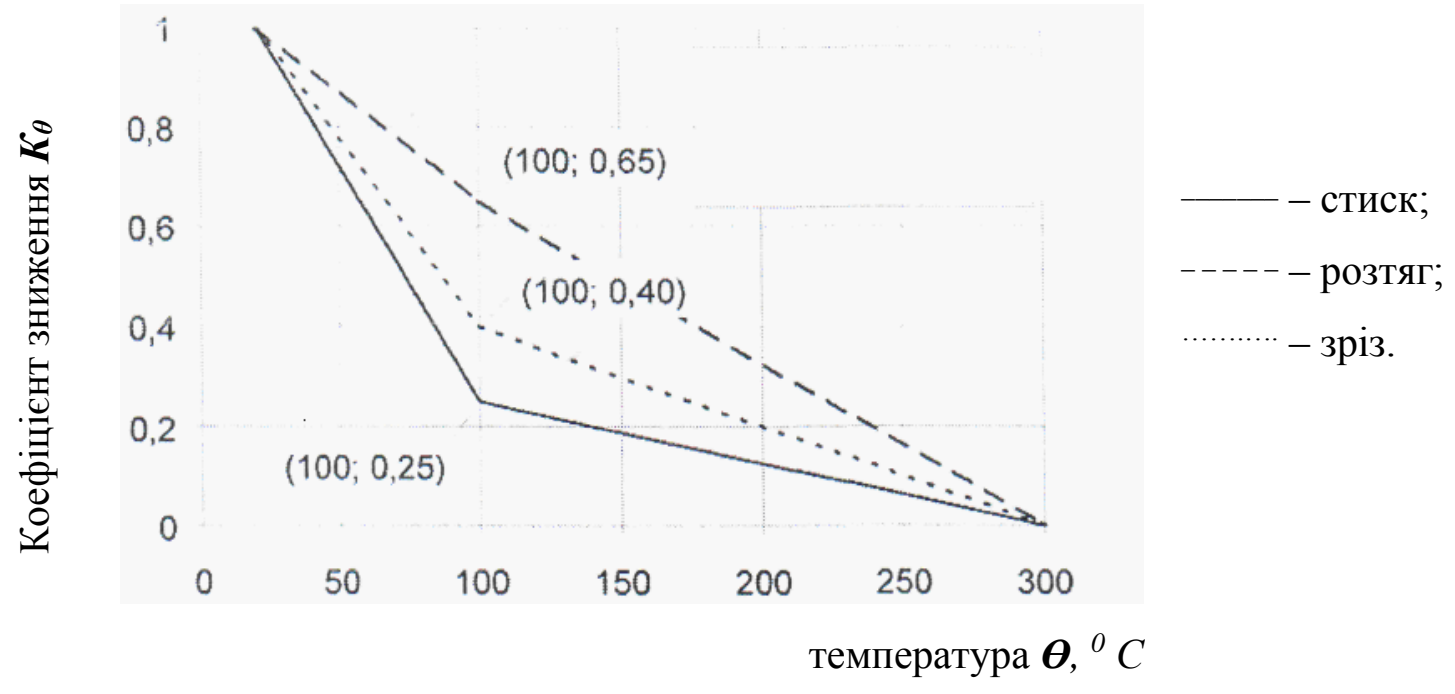

Рис. 1. Залежності зміни коефіцієнтів зниження міцності деревини на стиск, розтяг і зріз від температури.

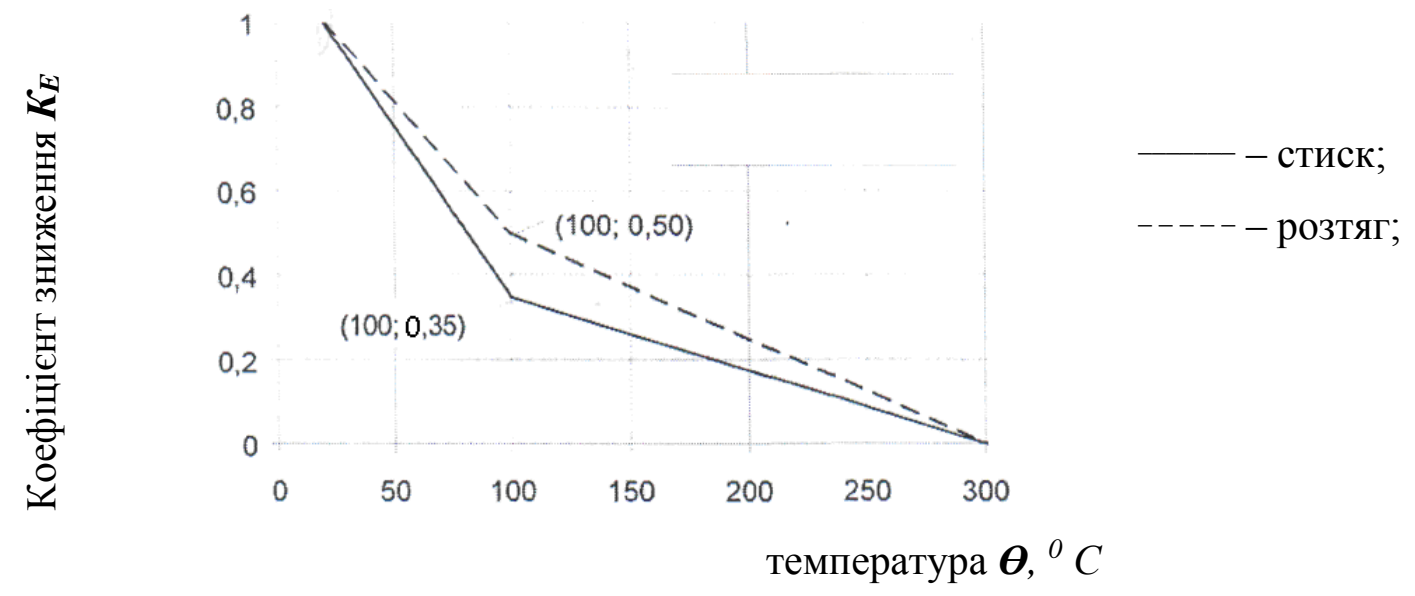

Рис. 2. Залежності зміни коефіцієнтів зниження модуля пружності деревини при стиску і розтягу від температури. 
Дані залежності несуть фізичний зміст співвідношення міцності (рис.1) та модуля пружності (рис.2), при певній температурі. Крім того ці залежності являються лінійними функціями з яскраво вираженими точками перегину при температурі $\theta=100{ }^{\circ} \mathrm{C}$. температури випаровування вільної води 3 деревини. Для їх апроксимації були використані ступінчасті функції Хевісайда [11]. 3 урахуванням цього залежності характеристик деревини мають вигляд (1):

$$
\left.\begin{array}{l}
k_{\theta, c}=[1-U(\theta-20)]+\left[\begin{array}{l}
U(\theta-20)- \\
-U(\theta-100)
\end{array}\right] \cdot\left[1-\frac{4,375}{1000} \cdot(\theta-20)\right]+ \\
+[U(\theta-100)-U(\theta-300)] \cdot[0,65-0,00325 \cdot(\theta-100)] ; \\
k_{\theta, t}=[1-U(\theta-20)]+\left[\begin{array}{l}
U(\theta-20)- \\
-U(\theta-100)
\end{array}\right] \cdot[1-0,0075 \cdot(\theta-20)]+ \\
+[U(\theta-100)-U(\theta-300)] \cdot[0,4-0,002 \cdot(\theta-100)] ; \\
k_{\theta, v}=[1-U(\theta-20)]+\left[\begin{array}{l}
U(\theta-20)- \\
-U(\theta-100)
\end{array}\right] \cdot\left[1-\frac{9,375}{1000} \cdot(\theta-20)\right]+ \\
+[U(\theta-100)-U(\theta-300)] \cdot\left[0,25-\frac{1,25}{1000} \cdot(\theta-100)\right] .
\end{array}\right\}
$$

де:

$k_{\theta, c}=\frac{f_{c, \theta}}{f_{c, 20}}$ - коефіцієнт зміни міцності деревини на стиск при температурі $\theta$;

$k_{\theta, t}=\frac{f_{t, \theta}}{f_{t, 20}}-$ те ж, на розтяг при температурі $\theta$;

$k_{\theta, v}=\frac{f_{v, \theta}}{f_{v, 20}}-$ те ж, на зріз при температурі $\Theta$;

$f_{\mathrm{c}, \theta}, f_{t, \theta}, f_{v, \theta}$ - фактичні міцності деревини на стиск, розтяг та зріз при температурі $\theta$ відповідно;

$f_{c, 20}, f_{t, 20}, f_{v, 20^{-}}$те ж, при температурі $20{ }^{\circ} C$;

$U(\mathrm{x})$ - функція Хевісайда [11];

$\theta \equiv \theta(x, y, z, t)$ - температура в розрахунковій точці колони.

Були також отримані залежності коефіцієнтів зміни модуля деформації деревини від температури (2):

$$
\left.\begin{array}{l}
k_{E, c}=[1-U(\theta-20)]+\left[\begin{array}{l}
U(\theta-20)- \\
-U(\theta-100)
\end{array}\right] \cdot[1-0,00625 \cdot(\theta-20)]+ \\
+[U(\theta-100)-U(\theta-300)] \cdot[0,5-0,0025 \cdot(\theta-100)] ; \\
k_{E, t}=[1-U(\theta-20)]+\left[\begin{array}{l}
U(\theta-20)- \\
-U(\theta-100)
\end{array}\right] \cdot[1-0,008125 \cdot(\theta-20)]+ \\
+[U(\theta-100)-U(\theta-300)] \cdot[0,35-0,00175 \cdot(\theta-100)] .
\end{array}\right\}
$$


Де, $k_{\mathrm{E}, \mathrm{c}}=\frac{\mathrm{E}_{\mathrm{c}, \theta}}{\mathrm{E}_{\mathrm{c}, 20}}-$ коефіцієнти зміни модуля деформації деревини для стиску при температурі $\theta$;

$k_{\mathrm{E}, t}=\frac{\mathrm{E}_{t, \theta}}{\mathrm{E}_{t, 20}}-$ те ж, для розтягу при температурі $\theta$;

$E_{c, \theta}, E_{t, \theta}$ - фактичні модулі деформації деревини для стику і розтягу при температурі $\theta$ відповідно;

$E_{\mathrm{c}, 20}, E_{t, 20}$ - те ж, при температурі $20{ }^{\mathrm{O}} \mathrm{C}$.

Отримані теоретичні залежності зміни міцності та модуля деформації деревини від температури нагріву дозволили визначити міцність і модуль деформації в будь-якій точці колони як функцію від температури.

Для спрощення обчислень (яке дозволяється при інженерних розрахунках), схеми для розрахункових перетинів були представлені у вигляді ступінчастої лінії (рис.3) по ширині перерізу колони b.

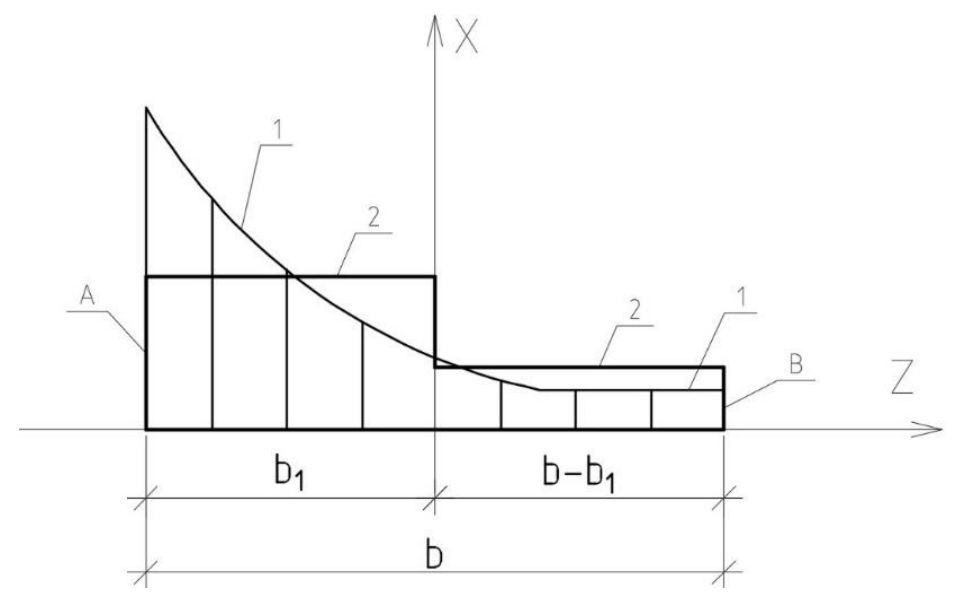

Примітка. Вісь «0Х» збігається з нейтральною віссю колони по висоті

Рис. 3. До апроксимації фактичних епюр ступінчастою лінією.

1 - фактична епюра; 2 - те ж, апроксимація.

Тому необхідно приводити до середнього значення температури і температурних залежностей в деякому об'ємі з координатами центру заданого шару матеріалу (це необхідно при використанні для вирішення поставленого завдання методу кінцевих елементів) і в деякому перетині колони з координатою «Х». 3 урахуванням сказаного і представленої на рис.3, схеми для довільного перерізу маємо:

1. Для визначення температури: 


$$
\left.\begin{array}{l}
\bar{T}=\frac{\int_{-D x / 2}^{D x / 2} \int_{-D y / 2}^{D y / 2} \int_{-D z / 2}^{D z / 2} T(x, y, z, t) \cdot d x \cdot d y \cdot d z}{D x \cdot D y \cdot D z} \\
a_{T}=\frac{\int_{0}^{h} \int_{0}^{b_{1}} T(x, y, z, t) \cdot d z \cdot d y}{b_{1} \cdot h} ; \\
b_{T}=\frac{\int_{0}^{h} \int_{b-b_{1}}^{b} T(x, y, z, t) \cdot d z \cdot d y}{\left(b-b_{1}\right) \cdot h}
\end{array}\right\}
$$

2. Для міцності деревини на стиск:

$$
\left.\begin{array}{l}
\bar{f}_{c}=\frac{\int_{-D x / 2}^{D x / 2} \int_{-D y / 2}^{D y / 2} \int_{-D z / 2}^{D z / 2} f_{c}(x, y, z, t) \cdot d x \cdot d y \cdot d z}{D x \cdot D y \cdot D z} ; \\
a_{f_{c}}=\frac{\int_{0}^{\square} \int_{0}^{b_{1}} f_{c}(x, y, z, t) \cdot d z \cdot d y}{b_{1} \cdot h} ; \\
b_{f_{c}}=\frac{\int_{0}^{\square} \int_{b-b_{1}}^{b} f_{c}(x, y, z, t) \cdot d z \cdot d y}{\left(b-b_{1}\right) \cdot h} ;
\end{array}\right\}
$$

3. Для міцності деревини на розтяг:

$$
\left.\begin{array}{rl}
\bar{f}_{t} & =\frac{\int_{-D x / 2}^{D x / 2} \int_{-D y / 2}^{D y / 2} \int_{-D z / 2}^{D z / 2} f_{t}(x, y, z, t) \cdot d x \cdot d y \cdot d z}{D x \cdot D y \cdot D z} \\
a_{f_{t}} & =\frac{\int_{0}^{h} \int_{0}^{b_{1}} f_{t}(x, y, z, t) \cdot d z \cdot d y}{b_{1} \cdot h} \\
b_{f_{t}} & =\frac{\int_{0}^{h} \int_{b-b_{1}}^{b} f_{t}(x, y, z, t) \cdot d z \cdot d y}{\left(b-b_{1}\right) \cdot h}
\end{array}\right\}
$$

4. Для міцності деревини на зріз:

$$
\left.\begin{array}{rl}
\bar{f}_{v} & =\frac{\int_{-D x / 2}^{D x / 2} \int_{-D y / 2}^{D y / 2} \int_{-D z / 2}^{D z / 2} f_{v}(x, y, z, t) \cdot d x \cdot d y \cdot d z}{D x \cdot D y \cdot D z} \\
a_{f_{v}} & =\frac{\int_{0}^{h} \int_{0}^{b_{1}} f_{v}(x, y, z, t) \cdot d z \cdot d y}{b_{1} \cdot h} ; \\
b_{f_{v}} & =\frac{\int_{0}^{h} \int_{b-b_{1}}^{b} f_{v}(x, y, z, t) \cdot d z \cdot d y}{\left(b-b_{1}\right) \cdot h}
\end{array}\right\}
$$

5. Для модуля пружності деревини на стиск: 


$$
\left.\begin{array}{l}
\bar{E}_{c}=\frac{\int_{-D x / 2}^{D x / 2} \int_{-D y / 2}^{D y / 2} \int_{-D z / 2}^{D z / 2} E_{c}(x, y, z, t) \cdot d x \cdot d y \cdot d z}{D x \cdot D y \cdot D z} ; \\
a_{E_{c}}=\frac{\int_{0}^{\square} \int_{0}^{b_{1}} E_{c}(x, y, z, t) \cdot d z \cdot d y}{b_{1} \cdot h} ; \\
b_{E_{c}}=\frac{\int_{0}^{\square} \int_{b-b_{1}}^{b} E_{c}(x, y, z, t) \cdot d z \cdot d y}{\left(b-b_{1}\right) \cdot h} ;
\end{array}\right\}
$$

6. Для модуля пружності деревини на розтяг:

$$
\left.\begin{array}{l}
\bar{E}_{t}=\frac{\int_{-D x / 2}^{D x / 2} \int_{-D y / 2}^{D y / 2} \int_{-D z / 2}^{D z / 2} E_{t}(x, y, z, t) \cdot d x \cdot d y \cdot d z}{D x \cdot D y \cdot D z} ; \\
a_{E_{t}}=\frac{\int_{0}^{\square} \int_{0}^{b_{1}} E_{t}(x, y, z, t) d z \cdot d y}{b_{1} \cdot h} ; \\
b_{E_{t}}=\frac{\int_{0}^{\square} \int_{b-b_{1}}^{b} E_{t}(x, y, z, t) d z \cdot d y}{\left(b-b_{1}\right) \cdot h} ;
\end{array}\right\}
$$

Висновки. Отримано аналітичний розв'язок задачі про розподіл міцностей деревини на стиск, розтяг та зріз в тілі нерівномірно, одностороньо нагрітої дерев'яної колони. В цьому випадку слід підставити розраховані за рівняннями температурні поля та отримані залежності для коефіцієнта зміни міцності деревини.

Отримано аналітичний розв'язок задачі що до деформаційних властивостей (модуля деформацій) при стиску і розтязі в перетинах нерівномірно нагрітої дерев'яної колони. В цьому випадку слід підставити розраховані температурні поля та отримані залежності для коефіцієнта зміни модуля деформацій деревини.

\section{References}

1. Shnal T. Vohnestiikist ta vohnezakhyst derevianykh konstruktsii: Navchalnyi posibnyk. [Fire resistance and fire protection of wooden structures: Textbook.] Lviv: Vydavnytstvo NU "Lvivska politekhnika," 2006. 220 p.

2. DBN V.2.6-161:2017. Dereviani konstruktsii. Osnovni polozhennia. [Wooden structures. Substantive provisions.] Kyiv: Minrehionbud Ukrainy, 2017. P. 111.

3. EN 1995-1-2:2004. Eurocode 5: Design of timber structures. - Part 1-2: General Structural fire design.

4. DSTU-N-P B V.2.6-157:2010 Konstruktsii budynkiv $i$ sporud. Proektuvannia derev ianykh konstruktsii. Chastyna 1-2. Zahalni polozhennia. Rozrakhunok konstruktsii na vohnestiikist [Constructions of buildings and structures. Design of wooden structures. Part 1- 
2. Terms. Calculation of structures for fire resistance] (EN 1995-1-2:2004, MOD). Kyiv: Minrehionbud Ukrainy, 2010.

5. Lau P.W.C., Zeeland I. V. Modelling the char behavior of structural timber // Proceedings of the Fire and Materials. 1998. P. 123-135.

6. Haksever A., Savaş S. Design of wood columns under real fire action. 2005. Vol. 16. P. 3713-3738.

7. Homon S. Kryterii ruinuvannia pozatsentrovostysnutykh ta zghynalnykh elementiv $z$ derevyny $z$ urakhuvanniam pruzhnoplastychnoi roboty materialu $z$ obmezhenoiu deformatyvnistiu // Resursoekonomni materialy, konstruktsii, budivli ta sporudy. [Criterion of destruction of eccentrically compressed and bending elements of wood, taking into account the elastic-plastic work of the material with limited deformability // Resource-saving materials, structures, buildings and structures] 2013. P. 248-253.

8. Kúdela J., Slaninka R. Stability of wood columns loaded in buckling. Part 2. Eccentric buckling // Drev. Vysk. Res. 2004. Vol. 49. P. 13-23.

9. Escalantea M., Rougier V., Rosales M.B. Buckling of wood columns with uncertain properties. Mecánica Computacional Vol XXXI, 2012. P. 2735-2744.

10. Pelekh A. The question of modeling the creep behavior of wood under high ambient temperatures // Sci. Eur. 2018. Vol. 2, № 25. P. 40-44.

11. Korn H., Korn T. Spravochnyk po matematyke. [Handbook of Mathematics.] Moskva, 1974. $840 \mathrm{p}$.

\section{Translation of the Title, Abstract and References to the Author's Language}

\section{Анотація}

Вогнестійкість дерев'яних конструкцій є важливим етапом проектування дерев'яних споруд. Уже багато років вчені всього світу досліджують поведінку споруди під час пожежі та намагаються спрогнозувати наслідки. У даній роботі розглянено роботу дерев'яних стиснутих елементів при дії локального нагріву. Метою роботи є за

допомогою аналітичних методів знайти вплив пожежі на стиснутий елемент у будь якій точці його перерізу. Оскільки сучасна нормативна база рекомендує використання наближених методів та емпіричних коефіцієнтів, що не дозволяє лиш наближено оцінити роботу конструктивного елементу під час пожежі, та врахувати нерівномірний нагрів тіла елементу. Для розв'язування задачі було використано математичні функції Хевісайда та системи дискретних рівнянь. У результаті отримано залежності які 
описують зміну міцнісних та деформативних характеристик у будь які точці тіла елементу при локальному його нагріві.

Ключові слова. дерево, високі температури, дерев'яні колони, пожежа, протипожежне проектування.

\section{Список посилань}

1. Шналь Т. Вогнестійкість та вогнезахист дерев'яних конструкцій: Навчальний посібник. Львів: Видавництво НУ “Львівська політехніка,” 2006. 220 р.

2. ДБН В.2.6-161:2017. Дерев’яні конструкції. Основні положення. Київ: Мінрегіонбуд України, 2017. Р. 111.

3. EN 1995-1-2:2004. Eurocode 5: Design of timber structures. - Part 1-2: General Structural fire design.

4. ДСТУ-Н-П Б В.2.6-157:2010 Конструкції будинків і споруд. Проектування дерев `яних конструкцій. Частина 1-2. Загальні положення. Розрахунок конструкцій на вогнестійкість (EN 1995-1-2:2004, MOD). Київ: Мінрегіонбуд України, 2010.

5. Lau P.W.C., Zeeland I. V. Modelling the char behaviour of structural timber // Proceedings of the Fire and Materials. 1998. P. 123-135.

6. Haksever A., Savaş S. Design of wood columns under real fire action. 2005. Vol. 16. P. 3713-3738.

7. Гомон С. Критерій руйнування позацентровостиснутих та згинальних елементів 3 деревини 3 урахуванням пружнопластичної роботи матеріалу 3 обмеженою деформативністю // Ресурсоекономні матеріали, конструкції, будівлі та споруди. 2013. P. 248-253.

8. Kúdela J., Slaninka R. Stability of wood columns loaded in buckling. Part 2. Eccentric buckling // Drev. Vysk. Res. 2004. Vol. 49. P. 13-23.

9. Escalantea M., Rougier V., Rosales M.B. Buckling of wood columns with uncertain properties. Mecánica Computacional Vol XXXI, 2012. P. 2735-2744.

10. Pelekh A. The question of modeling the creep behavior of wood under high ambient temperatures // Sci. Eur. 2018. Vol. 2, № 25. P. 40-44.

11. Корн Г., Корн Т. Справочник по математике. Москва, 1974. 840 р. 


\section{Manuscript Guidelines}

1. All submitted papers must contain the Title, Name of author(s), Affiliation (if any), Abstract and List of References (Literature) written in English. The Abstract must count not less than 100 and not more than 300 words and must be the good representation of your article. Optionally paper may also contain this information duplicated in another language.

2. Font faces. Arial, Times, Times New Roman, Courier New and Helvetica.

3. Language. You may use any language for your paper text, however English is MUCH preferable.

4. Title. Font size - 16, bold. Position - central alignment.

5. The author's name. Font size - 14, bold. Position - central alignment.

6. The affiliation (your University etc). Font size - 14, regular (not bold). Position - left alignment.

7. The word "Abstract". Font size - 12, bold-italics. Position - central alignment.

8. The text of the abstract. Font size - 10, regular (not bold).

9. The word "Keywords" (if any). Font size - 10, bold. Position - left alignment.

10. The text of keywords (if any). Font size - 10, regular (not bold). Position - left alignment.

11. Text of article. Font size - 14. Position - left alignment or fully justified. Line spacing - 1.5 lines.

12. The word "References" (if any). Font size - 12, bold-italics. Position - central alignment.

13. The text of References (if any). Font size - 12, regular (not bold).

In all other cases please use your own good judgment or contact our Editorial Board.

\section{Where to find us}

The "IntellectualArchive" is distributed to major libraries across Canada and the US, including

Library of Congress, USA (http://lccn.loc.gov/cn2013300046 ) ,

Library and Archives Canada

(http://collectionscanada.gc.ca/ourl/res.php?url_ver=Z39.88-2004\&url_tim=2012-09-

05T01\%3A46\%3A54Z\&url_ctx_fmt=info\%3Aofi\%2Ffmt\%3Akev\%3Amtx\%3Actx\&rft_dat=40904933\&r

fr_id=info\%3Asid\%2Fcollectionscanada.gc.ca\%3Aamicus\&lang=eng) and others.

The references to articles published in the "IntellectualArchive" are available in the

Google Scholar, (http://scholar.google.ca/scholar?q=\%22IntellectualArchive\%22 ),

Arxiv.org (http://search.arxiv.org:8081/?query=\%22Intellectual\%20Archive\%22\&in= ),

WorldCat.org (https://www.worldcat.org/search?q=n2\%3A1929-4700\&qt=advanced \&dblist=638 ) ,

Academia.edu

(http://www.academia.edu/15503799/Light_diffraction_experiments_that_confirm_the_STOE_model_and

_reject_all_other_models )

The National Research Council (Italy) (http://data.cnr.it/data/cnr/individuo/rivista/ID658222 )

Наукова бібліотека of the University named after Dragomanov, Ukraine

(http://enpuir.npu.edu.ua/handle/123456789/7974?mode=full )

Google.com (https://www.google.ca/\#q=site:IntellectualArchive.com ) thousands of links etc. 